UNIVERSIDADE DE SÃO PAULO

ESCOLA DE ENGENHARIA DE SÃO CARLOS

DEPARTAMENTO DE HIDRÁULICA E SANEAMENTO

PROGRAMA DE PÓS-GRADUAÇÃO EM ENGENHARIA HIDRÁULICA E SANEAMENTO

\title{
DESEMPENHO DE FILTRO BIOLÓGICO NA DEPURAÇÃO E DESODORIZAÇÃO DE EMISSÕES DE SULFETO DE HIDROGÊNIO
}

\author{
Alexandre Prado Rocha
}

Dissertação apresentada a Escola de Engenharia de São Carlos, da Universidade de São Paulo, para obtenção do titulo de Mestre em Hidráulica e Saneamento.

Orientador: Prof. Dr. Edson Luiz Silva

São Carlos

Estado de São Paulo 
AUTORIZO A REPRODUÇÃO E DIVULGAÇÃO TOTAL OU PARCIAL DESTE TRABALHO, POR QUALQUER MEIO CONVENCIONAL OU ELETRÔNICO, PARA FINS DE ESTUDO E PESQUISA, DESDE QUE CITADA A FONTE.

Ficha catalográfica preparada pela Seção de Tratamento da Informação do Serviço de Biblioteca - EESC/USP

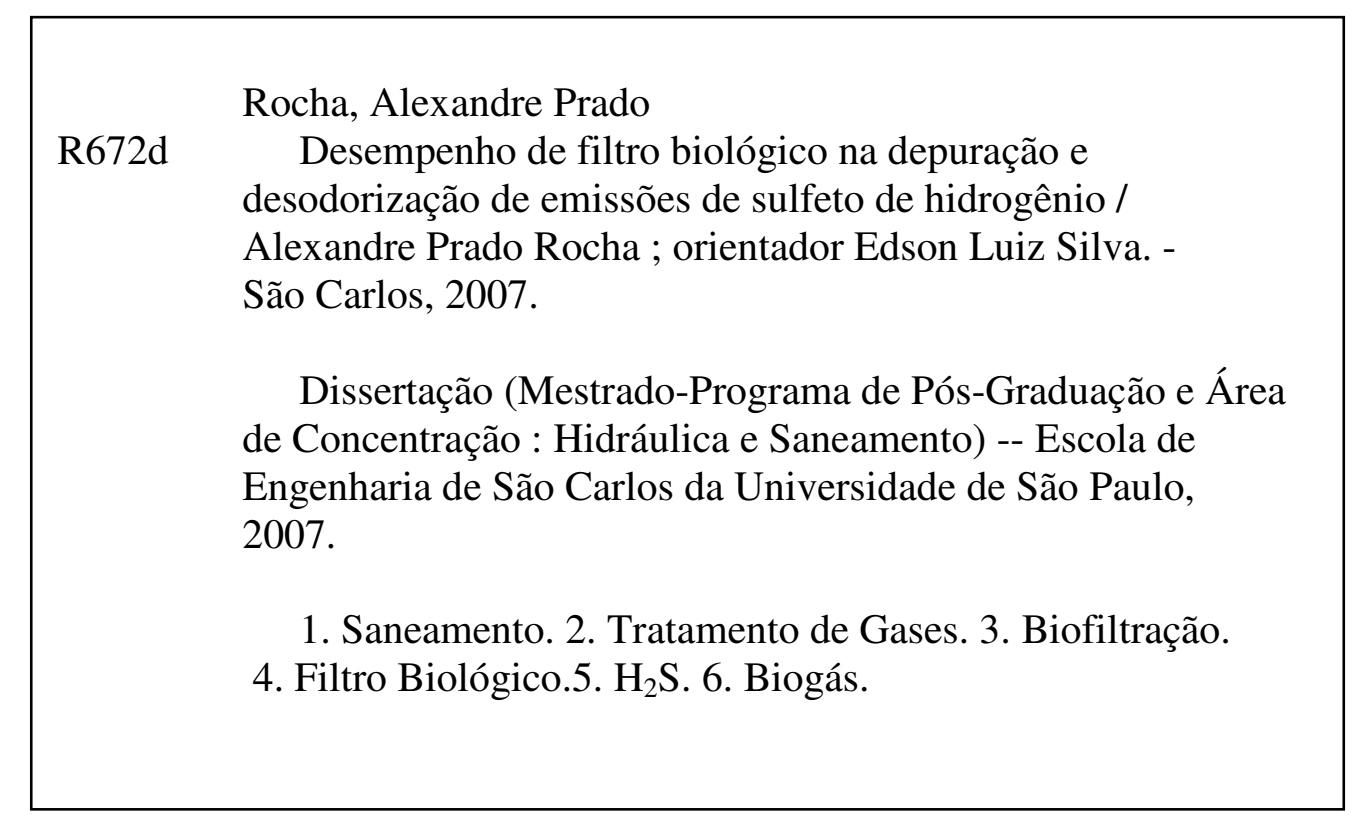




\section{DEDICO}

À minha filha Sara e minha esposa Luciana, que sempre estiveram ao meu lado mesmo estando a quilômetros de distância, superando e me ajudando a superar, com muito amor, a ausência que se fez necessária para conclusão deste trabalho.

Ao meu pai Salomão e minha mãe Regina, que se privaram de privilégios para que eu pudesse continuar meus estudos e para que pudesse retornar à eles com muito orgulho o grau de Mestre.

Ao meu avô Lázaro, que mesmo não estando mais comigo para desfrutar desse momento, se sentiria orgulhoso e à minha avó Izaide, que tanto me incentivou para concluí-lo.

Aos meus familiares que sempre me apoiaram e me lembram que após a tempestade vem sempre a bonança. 


\section{AGRADECIMENTOS}

Quero mostrar minha gratidão a todos que contribuíram para a realização desta dissertação, especialmente:

À minha filha Sara que foi a grande motivação e inspiração para realização e conclusão desse trabalho.

Meus pais Salomão e Regina pelo seu incentivo, apoio, e compreensão.

À minha esposa Luciana que mais se doou com muito amor, dedicação, compreensão e ajuda nas horas difíceis.

Aos meus avós Lazaro e Izaide e minha irmã Luciane por todo apoio e carinho.

Ao Prof. Dr. Edson Luiz Silva por acreditar e ter grande confiança em mim, pela ótima orientação e principalmente por sua amizade.

Ao meu amigo Eduardo Lucena pela grande ajuda na realização da parte experimental principalmente nos finais de semana.

Aos demais colegas do Laboratório de Controle Ambiental 2, Eduardo Lucena, Laura Siqueira, Camila Abbati, e Maressa Cuel, pelos momentos de descontração e pela companhia.

Ao técnico Oscar da Silva, pela construção do reator, pela ajuda durante o desenvolvimento do trabalho e nas horas de sufoco.

A ETE do Piracicamirim pelo fornecimento do lodo.

À Prof ${ }^{a}$. Dra Maria Bernadete A. Varesche, Érika Sarti e Ana Carolina pelas análises microscópicas.

Ao Sr. Nelson Gallo do Instituto de Física da Universidade de São Carlos pelas análises de microscopia eletrônica de varredura e EDX.

Ao Prof. Dr. Sergio Arnosti Jr. pelas orientações e contribuições na qualificação.

Ao Prof. Titular Eugênio Foresti pela oportunidade em participar do Projeto Temático.

Ao CNPq pela bolsa e FAPESP pelo investimento no Laboratório de Controle Ambiental II do Departamento de Engenharia Química da UFSCar. 


\section{RESUMO}

ROCHA, A. P. Desempenho de filtro biológico na depuração e desodorização de emissões de sulfeto de hidrogênio. Dissertação (Mestrado) - Escola de Engenharia de São Carlos, Departamento de Hidráulica e Saneamento, Universidade de São Paulo, São Carlos, 2007.

Os efluentes gasosos industriais têm sido tradicionalmente tratados por processos físico-químicos, como lavadores, adsorção, condensação e oxidação. Embora essas técnicas tenham altas eficiências, a necessidade de adição de produtos químicos e a substituição do adsorvente resulta em custo de operação relativamente alto quando comparados com técnicas de tratamento biológico. O objetivo deste trabalho foi: aprimorar uma unidade experimental de biofiltração para depuração de uma corrente gasosa contendo $\mathrm{H}_{2} \mathrm{~S}$ utilizando como material suporte a espuma de poliuretano, analisar a fluidodinâmica do leito através de ensaios de perda de carga em função da vazão de ar e da umidade do leito e analisar o desempenho do biofiltro na depuração do $\mathrm{H}_{2} \mathrm{~S}$ com o aumento progressivo da concentração de entrada. O biofiltro foi construído com uma coluna de acrílico, dividida em 3 módulos, 2 com $13 \mathrm{~cm}$ de altura e um central com $50 \mathrm{~cm}$, totalizando uma altura do leito de $76 \mathrm{~cm}$ e o diâmetro interno era de $5,2 \mathrm{~cm}$. Nas extremidades superiores e inferiores do biofiltro foram acoplados módulos para a distribuição e captação da corrente gasosa e também para a recirculação da fase líquida. O inóculo utilizado foi lodo de uma unidade de lodos ativados, que trabalha como pós-tratamento de um reator UASB tratando esgotos domésticos. A adaptação do inóculo foi realizada por 7 dias com tiossulfato e 7 dias com o $\mathrm{H}_{2} \mathrm{~S}$. As concentrações médias de sulfeto estudadas foram subdivididas em sete fases com concentrações médias de 141, 271, 514, 532, 581, 878 e 1303 ppm. A vazão utilizada foi de 100 L.h ${ }^{-1}$ resultando em um tempo de detenção de aproximadamente 58 segundos. As perdas de carga obtidas no sistema foram inferiores a $0,8 \cdot 10^{-2}$ mca. A espuma de poliuretano se apresentou um bom meio suporte para a fixação dos microrganismos. $\mathrm{O}$ lodo ativado se apresentou um bom inóculo para o tratamento de $\mathrm{H}_{2} \mathrm{~S}$ por necessitar de um curto período de tempo para sua adaptação. A eficiência média do biofiltro se manteve acima dos $96 \%$. A umidade do leito se manteve acima de $92 \%$, atingindo uma capacidades de eliminação máxima $\left(\mathrm{EC}_{\text {máx }}\right)$ de aproximadamente $155 \mathrm{~g} \cdot \mathrm{m}^{-3} \cdot \mathrm{h}^{-1}$ e uma capacidade de eliminação ótima (EC ótimo$_{\text {) }}$ de aproximadamente $139 \mathrm{~g} \cdot \mathrm{m}^{-3} \cdot \mathrm{h}^{-1}$. O principal produto da degradação do $\mathrm{H}_{2} \mathrm{~S}$ encontrado foi o enxofre elementar.

Palavras chaves: Tratamento de Gases, Biofiltração, Filtro Biológico, $\mathrm{H}_{2} \mathrm{~S}$, Biogás. 


\begin{abstract}
Traditionally the industrial waste gases have been treated by physical-chemical processes, such as scrubbers, absorption, condensation and oxidation. Although these techniques presented great efficiency, the need to add chemical products and the replacement of adsorbent results in relatively high operational costs compared to biological treatment techniques. The objective of this study is to improve an experimental biofiltration unit to remove air steam containing $\mathrm{H}_{2} \mathrm{~S}$, using polyurethane foam as filter bed, to analyze the bed dynamic flow through pressure drop and the bed moisture, and to analyze the biofilter behavior during the $\mathrm{H}_{2} \mathrm{~S}$ depuration with the progressive increase of input concentration. The bio-filter has an acrylic column, divided into 3 parts, from which two are $13 \mathrm{~cm}$ high and the central one is $50 \mathrm{~cm}$ high, adding up to a $76 \mathrm{~cm}$ high column with an inner diameter of $5.2 \mathrm{~cm}$. Modules were attached on the top and bottom biofilter extremities to distribute and collect the air stream and also to recirculate the liquid phase. The inoculum used was a sludge from a activated sludge unit, which works as posttreatment for domestic sewer treated by a UASB reactor. The inoculum acclimatizing was done for 7 days with thiosulphate and 7 days with $\mathrm{H}_{2} \mathrm{~S}$. The studied measured hydrogen sulphide concentrations were divided into seven average concentration levels, which are

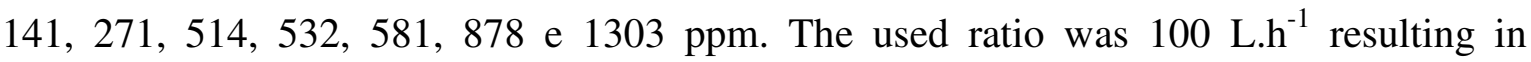
hydraulic retention time of approximately 58 seconds. The head losses obtained in the system were below $0.810^{-2}$ mca. The polyurethane foam presented to be a good support manner to the microorganisms attach. The activated sludge presented to be a good inoculum for the treatment of $\mathrm{H}_{2} \mathrm{~S}$ because it required a short time to adapt. The average efficiency of the biofilter kept above $96 \%$ and the bed humidity above $92 \%$, reaching the maximum elimination capacity $\left(\mathrm{EC}_{\mathrm{máx}}\right)$ of approximately $155 \mathrm{~g} \cdot \mathrm{m}^{-3} \cdot \mathrm{h}^{-1}$ and a optimum elimination capacity of approximately $139 \mathrm{~g} \cdot \mathrm{m}^{-3} \cdot \mathrm{h}^{-1}$. The main $\mathrm{H}_{2} \mathrm{~S}$ degradation product found was the elemental sulfur.
\end{abstract}

Keywords: gas treatment, biofiltration, biological filter, $\mathrm{H}_{2} \mathrm{~S}$, biogas. 


\section{LISTA DE FIGURAS}

Figura 1 - Circulação do enxofre no meio ambiente. Os números mostram os montantes do enxofre liberado em cada processo expresso em megatoneladas por ano. 8 Figura 2 - Ciclo biológico do enxofre 9 Figura 3 - Esquema dos sistemas mais comuns de tratamento biológico de gases 21 Figura 4 - Curva de ruptura típica para adsorção em leito fixo.

Figura 5 - Curvas de ruptura para recheios com diferentes características: a) recheio homogêneo; b) recheio com canais preferenciais; c) recheio com zonas de estagnação e

d) recheio com zonas mortas.

Figura 6 - Curva de ruptura para tolueno.

Figura 7 - Espuma de poliuretano cortadas em cubos de $5 \mathrm{~mm}$.

Figura 8 - Espuma de poliuretano com aumento de 20 vezes.

Figura 9 - Montagem do sistema de biofiltração (1) Cilindro de H2S puro; (2) Válvula agulha; (3) Contador de bolhas; (4) Trompa de vácuo para diluição do H2S; (5) Compressor; (6) Válvula reguladora de pressão; (7) Umidificador; (8) Misturador; (9 e 16) Rotâmetros; (10) Válvula para acerto da vazão de entrada no reator; (11) Amostrador de entrada; (12) Amostrador de saída; (13) Biofiltro; (14) Inóculo reserva; (15) Tanque de $\mathrm{NaOH}$, (16) Bomba de recirculação.

Figura 10 - Sistema de umidificação

Figura 11 - Partes do biofiltro desmontado

Figura 12 - Módulo inferior do Biofiltro

Figura 13 - Biofiltro.

Figura 14 - Parte superior do biofiltro.

Figura 15 - Visão geral do sistema.

Figura 16 - Valores de perda de carga para espuma de poliuretano seca em função da velocidade superficial do ar.

Figura 17 - Valores de perda de carga para espuma de poliuretano úmida em função da velocidade superficial de ar.

Figura 18 - Valores de perda de carga para espuma de poliuretano com 121 dias de operação no biofiltro em função da velocidade superficial de ar.

Figura 19 - Comparação dos valores das perdas de cargas seca, úmida, após a operação do sistema considerando alturas do leito de 60 e $76 \mathrm{~cm}$ em função da velocidade superficial do ar. 
Figura 20 - Comparação dos valores das perdas de cargas seca calculada por Darcy e por ERGUN em função da velocidade superficial de ar.

Figura 21 - Curva de ruptura.

Figura 22 - Valores de concentração de H2S na entrada e saída do biofiltro durante a operação do sistema.

Figura 23 - Valores médios de concentração na entrada e na saída nas 7 fases de operação do biofiltro.

Figura 24 - Eficiência de remoção do biofiltro.

Figura 25 - Valores de Concentração de entrada, saída e eficiência do biofiltro na primeira fase.

Figura 26 - Valores de concentração de entrada, saída e eficiência do biofiltro na segunda fase.

Figura 27 - Valores de concentração de entrada e saída do biofiltro na quarta fase.78

Figura 28 - Valores de concentração de entrada e saída do biofiltro na quinta fase.79

Figura 29 - Valores de concentração de entrada e saída do biofiltro na sexta fase. 81

Figura 30 - Concentrações de entrada e saída do biofiltro na sétima fase.

Figura 31 - Gráfico de pH durante a operação do biofiltro.

Figura 32 - Perfil de degradação do sulfeto no leito.

Figura 33 - Capacidade de eliminação do biofiltro em função da concentração de entrada.

Figura 34 - Capacidade de eliminação em função da taxa de carregamento.

Figura 35 - Capacidade de eliminação do biofiltro corrigida a altura do leito na sétima fase.

Figura 36 - Microscopia óptica de contraste da fase da biomassa destacando a presença de protozoários.

Figura 37 - Microscopia óptica de contraste da fase da biomassa destacando a presença de bacilos.

Figura 38 - Microscopia óptica de luz comum destacando a presença de cristais de enxofre.

Figura 39 - MEV da espuma de poliuretano com aumento de 3000x, após inoculação com lodo: bacilos e protozoários.

Figura 40 - MEV da espuma de poliuretano com aumento de 2000x, após inoculação com lodo: bacilos e coco-bacilos. 
Figura 41 - MEV da espuma de poliuretano com aumento de 2500x, após inoculação com lodo: sarcina.

Figura 42 - MEV da espuma de poliuretano com aumento de 5000x: grânulos de enxofre.

Figura 43 - MEV da espuma de poliuretano com aumento de 3000x:grânulos de enxofre.

Figura 44 - MEV com aumento de 5000x: grânulos de enxofre.

Figura 45 - Colmatação do leito de espuma.

Figura 46 - Fotos das espumas utilizadas no biofiltro.

Figura 47 - Detalhe da deformação da espuma.

Figura 48 - Foto comparativa da redução de tamanho das espumas. 


\section{LISTA DE TABELAS}

TABELA 1 - Limites de exposição de gases e vapores tóxicos.

TABELA 2 - Processos convencionais para a depuração e desodorização de gases e vapores industriais.

TABELA 3 - Características de alguns microrganismos utilizados na degradação de $\mathrm{H} 2 \mathrm{~S}$ ou compostos sulfurosos.

17

TABELA 4 - Mecanismos responsáveis pela remoção de compostos odorantes em biofiltros com lodo ativado.

TABELA 5 - Vantagens e desvantagens dos reatores biológicos.

TABELA 6 - Principais poluentes removidos por biofiltração e sua biodegradabilidade.

TABELA 7 - Pesquisas realizadas na remoção de Sulfeto de Hidrogênio utilizando Biofiltros.

TABELA 8 - Meio ATCC290-S6.

TABELA 9 - Freqüência de análises no ensaio de adsorção.

TABELA 10 - Duração das fases do sistema e suas concentrações médias. 55

TABELA 11 - Permeabilidades do leito obtida graficamente. 64

TABELA 12 - Porosidade do leito e da espuma.

TABELA 13 - Comparação dos dados obtidos de porosidade da espuma e permeabilidade do leito.

TABELA 14 - Dados de umidade e porosidade do leito por secção.

TABELA 15 - Comparação dos resultados perda de carga da literatura com os deste trabalho.

TABELA 16 - Dados obtidos no ensaio de adsorção.

TABELA 17 - Duração das fases do sistema, suas concentrações médias de entrada (CeH2S), saída (CsH2S) e eficiência.

70

TABELA 18 - Resultados obtidos na primeira fase de operação do sistema.

TABELA 19 - Resultados obtidos na segunda e terceira fases de operação do sistema.

TABELA 20 - Resultados obtidos na quarta fase de operação do sistema. 
TABELA 21 - Resultados obtidos na quinta fase de operação do sistema.

TABELA 22 - Valores obtidos na operação do biofiltro durante a sexta fase. $\quad 80$

TABELA 23 - Valores obtidos na operação do biofiltro durante a sétima fase. 82

TABELA 24 - Capacidade de eliminação máxima e ótima. 86

TABELA 25 - Capacidade de eliminação máxima encontrada em pesquisas anteriores.

TABELA 26 - Resultados obtidos pelo EDX. 
ACGIH $=$ American Conference of Governmental Industrial Hygienists ATCC $=$ American Type Culture Collection

DEQ = Departamento de Engenharia Química

DMDS $=$ Dimetil Disulfeto

DMS $=$ Dimetil Sulfeto

$\mathrm{EPA}=$ Environmental Protection Agency

$\mathrm{ETE}=$ Estação de tratamento de Esgoto

HMDS = Hexametildesilasani

LCA 2 = Laboratório de Controle Ambiental 2

MEV = Microscopia Eletrônica de Varredura

STEAL $=$ Short Term Exposure Limit

TDH = Tempo de Detenção Hidráulica

TLV $=$ Threshold Limit Values

TWA $=$ Time Weighted Average

VOCs $=$ Volatile Organic Compounds 


\section{LISTA DE SÍMBOLOS}

$\eta=$ Eficiência de remoção

$\gamma=$ Esfericidade

$\rho=$ Massa específica

$\varepsilon=$ Porosidade

$\rho_{\text {esp }}=$ Densidade específica da espuma

$\varepsilon_{\text {esp }}=$ Porosidade da espuma

$\varepsilon_{\text {leito }}=$ Porosidade do leito

$\mu=$ Viscosidade

$24,44=$ Volume molar corrigido para 1 atm e $25^{\circ} \mathrm{C}$

$\mathrm{C}=$ Concentração de saída

$\mathrm{C}_{\left(\mathrm{H}_{2} \mathrm{~S}\right)}=$ Concentração de $\mathrm{H}_{2} \mathrm{~S}$

$\mathrm{C}_{(\mathrm{mg} / \mathrm{L})}=$ Concentração calculada

$\mathrm{C}_{\left(\mathrm{mg} / \mathrm{m}^{3}\right)}{ }^{3}=$ Concentração calculada

$\mathrm{C}_{0}=$ Concentração de entrada

$\mathrm{C}_{\mathrm{b}}=$ Concentração desejada na saída

$\mathrm{C}_{\mathrm{E}}=$ Concentração lida no espectrofotômetro

$\mathrm{C}_{\mathrm{e}(\mathrm{H} 2 \mathrm{~S})} ; \mathrm{C}_{\mathrm{ent}}=$ Concentração de entrada

$\mathrm{C}_{\mathrm{s}\left(\mathrm{H}_{2} \mathrm{~S}\right)} ; \mathrm{C}_{\mathrm{sai}}=$ Concentração de saída

$\mathrm{D}=$ Diluição da amostra

$\mathrm{D}_{\mathrm{EQ}}=$ Diâmetro da partícula ou esfera equivalente

$\mathrm{D}_{\mathrm{V}}=$ Diâmetro médio

$\mathrm{Ec}=$ Capacidade de eliminação

$\mathrm{Ec}_{(\text {máx })}=$ Capacidade de eliminação máxima

$\mathrm{Ec}_{(\text {Ótimo })}=$ Capacidade de eliminação ótima

$\mathrm{K}=$ Permeabilidade do meio poroso

$\mathrm{L}=$ Comprimento do leito

$\mathrm{L}_{\mathrm{S}}=$ Taxa de Carregamento

$\mathrm{m}_{\mathrm{e}}=$ Massa de espuma seca

$\mathrm{m}_{\text {esp }}=$ Massa da espuma

$\mathrm{Mol}_{\mathrm{H}_{2} \mathrm{~S}}=$ Massa molecular do $\mathrm{H}_{2} \mathrm{~S}$

$\mathrm{m}_{\mathrm{t}}=$ Massa total do leito 
$\mathrm{Q}=$ Vazão

$\mathrm{T}=$ Temperatura

$\mathrm{t}=$ Tempo

$\mathrm{t}_{\mathrm{b}}=$ Tempo de ruptura

$\mathrm{v}=$ Velocidade Superficial

$\mathrm{V}=$ Volume

$\mathrm{V}_{(\mathrm{L})}=$ Volume da amostra

$\mathrm{V}_{\mathrm{esp}}=$ Volume da espuma

$\mathrm{V}_{\mathrm{P}} / \mathrm{S}_{\mathrm{P}}=$ Volume da razão de área superficial pelo sistema de partícula

$\mathrm{V}_{\mathrm{t}}=$ Volume total do leito

$\mathrm{V}_{\mathrm{v}}=$ Volume de vazios

$\Delta \mathrm{P}=$ Queda de pressão 


\section{SUMÁRIO}

1. INTRODUÇÃO 1

2. OBJETIVOS 5

3. REVISÃO BIBLIOGRÁFICA 6

3.1. Ciclo do enxofre 7

3.2. Tratamento de efluentes gasosos 10

3.3. Solubilidade dos poluentes 15

3.4. Oxidação biológica de $\mathrm{H}_{2} \mathrm{~S} \quad 15$

3.5. Biotecnologias para remoção de $\mathrm{H}_{2} \mathrm{~S} \quad 20$

3.6. Fatores ambientais da Biofiltração 25

3.6.1. Necessidades nutricionais dos biofiltros 26

3.6.2. O meio suporte na biofiltração 26

3.6.3. Teor de umidade no biofiltro 30

3.6.4. A importância do $\mathrm{pH}$ em biofiltros 31

3.6.5. A influência da temperatura nos biofiltros 31

3.6.6. Tempo de residência e altura do leito dos biofiltros 32

3.7. Resultados de pesquisas 32

4. MATERIAIS E MÉTODOS 39

4.1. Inóculo e Meio de Cultura 39

4.2. Adaptação do Inóculo $\quad 39$

4.3. Espuma de poliuretano como meio suporte 40

4.4. Empacotamento do recheio 42

4.5. Sistema de biofiltração 43

4.6. Ensaios hidrodinâmicos 50

4.7. Análise de sulfeto 52

4.8. Ensaio de Adsorção 54

4.9. Operação contínua do biofiltro 55

4.10. Capacidade de Eliminação, Taxa de carregamento e Eficiência de Remoção 56

4.11. Microscopia Óptica. 58

4.12. Metodologia de preparo das amostras de espuma de poliuretano para Microscopia Eletrônica de Varredura $\quad 58$

5. RESULTADOS E DISCUSSÕES 60

5.1. Ensaios Hidrodinâmicos 60 
5.2. Adsorção do $\mathrm{H}_{2} \mathrm{~S} \quad 68$

5.3. Biofiltração do $\mathrm{H}_{2} \mathrm{~S} \quad 70$

5.4. Perfil de degradação do sulfeto ao longo do leito. 84

5.5. A capacidade de eliminação $\quad 84$

5.6. Microscopia Óptica $\quad 88$

5.7. Microscopia Eletrônica de Varredura 90

5.8. Colmatação do Leito 94

6. CONCLUSÕES 97

7. DIFICULDADES EXPERIMENTAIS 99

8. SUGESTÕES DE CONTINUIDADE 100

9. REFERÊNCIAS BIBLIOGRÁFICAS 101

10. ANEXOS 113 


\section{INTRODUÇÃO}

A emissão de poluentes gasosos por fontes antrópicas tem maior relevância nas áreas urbanas que os emitidos pela natureza, por serem lançados de forma pontual, em grandes quantidades e normalmente muito próximo a essas áreas. Segundo Jorio e Heitz (1999) até meados dos anos 70 minimizou-se a importância desta poluição e sempre se escondeu à amplitude do problema pelo aumento da altura das chaminés industriais, mas com a promulgação do "Clean Air Act" em 1970 ocorreram algumas melhoras. Desta forma, se pôde notar uma forte diminuição das partículas de chumbo e de monóxido de carbono na maior parte das grandes cidades, porém, muitos problemas ainda continuam.

Com a maior compreensão dos efeitos causados pela poluição atmosférica em todas as formas de vida, foram criadas legislações ambientais para obrigar as empresas a controlar as emissões gasosas que ofereciam riscos potenciais a saúde humana como câncer e danos no sistema respiratório, e também a controlar os compostos que causam degradação ambiental como os precursores do "smog", gases do efeito estufa, compostos que afetam a camada de ozônio, compostos orgânicos voláteis (Volatile Organic Compounds - VOCs), compostos tóxicos, compostos odorantes e os compostos de enxofre que provocam a chuva ácida (DEVINNY et al. 1999).

$\mathrm{O}$ enxofre nas suas diversas composições $\left(\mathrm{SO}_{4}{ }^{2-}, \mathrm{S}_{2} \mathrm{O}_{3}{ }^{2-}, \mathrm{H}_{2} \mathrm{~S}\right.$, etc.) está distribuído de forma ampla na natureza. A interação desses compostos com os fatores bióticos e abióticos determina uma série de transformações que irão reciclar as várias formas de enxofre. O enxofre orgânico, encontrado nas proteínas dos seres vivos, poderá se transformar em gás sulfídrico $\left(\mathrm{H}_{2} \mathrm{~S}\right)$ pela ação dos microrganismos decompositores de matéria orgânica morta. $\mathrm{O}$ sulfato presente em ambientes anaeróbios, também poderá se transformar em $\mathrm{H}_{2} \mathrm{~S}$, como consequiência do metabolismo das bactérias redutoras de sulfato (OPRIME, 2001).

Dentre as várias formas de enxofre encontradas na natureza, o $\mathrm{H}_{2} \mathrm{~S}$ é considerado um dos principais agentes contaminantes da atmosfera. O sulfeto de hidrogênio geralmente encontrado na natureza é resultado, principalmente, de atividades vulcânicas, evaporação de águas oceânicas e fontes naturais de água quente (JANSEN et al., 1999), antropicamente é proveniente de refinarias de petróleo, curtumes e abatedouros, mineração, industrias de celulose e papel, corantes, pigmentos, fertilizantes, adesivos, 
viscose, celofane, rayon, tecidos sintéticos, estações de tratamento de água residuárias, industrias químicas de carbonato de bário, sais de bário, acido sulfúrico, sulfetos inorgânicos, purificação de fosfatos (DI BERNARDO et al., 1989; MORAES JUNIOR, 1991).

Com relação a estações de tratamento de águas residuárias, Rands et al. (1981) e Noyola et al. (2006) afirmam que a as concentrações de $\mathrm{H}_{2} \mathrm{~S}$ presentes no biogás dos reatores anaeróbio tratando esgotos domésticos variam de 10 a 820 ppm podendo atingir valores de 1000 ppm em digestores anaeróbios de lodo.

Após sua liberação, o $\mathrm{H}_{2} \mathrm{~S}$ é oxidado a dióxido de enxofre $\left(\mathrm{SO}_{2}\right)$ o qual é convertido a ácido sulfúrico $\left(\mathrm{H}_{2} \mathrm{SO}_{4}\right)$, que retorna ao solo na forma de "chuva ácida". Como a presença de $\mathrm{H}_{2} \mathrm{~S}$ e também de outras formas de enxofre é altamente significativa em combustíveis fósseis (petróleo e carvão, por exemplo), a utilização intensa destes combustíveis em áreas altamente industrializadas, determina uma liberação significativa de $\mathrm{SO}_{2}$, agravando a intensidade das "chuvas ácida" (OPRIME, 2001).

Mais especificamente, o gás sulfídrico é um gás incolor, corrosivo, com odor típico de "ovo podre", que também é denominado gás hidrosulfúrico ou sulfeto de hidrogênio e pode ser percebido pelo olfato humano a concentrações de até $0,5 \mathrm{ppb}\left(7 \mu \mathrm{g} / \mathrm{m}^{3}\right)(\mathrm{STERN}, 1976)$.

Devido à sua toxicidade, propriedades corrosivas, odores indesejáveis e alta demanda de oxigênio, o sulfeto é um dos principais problemas associados aos tratamentos de águas residuárias e outras atividades industriais, portanto, deve ser rigorosamente controlado (BUISMAN et al., 1990).

Dessa forma, sua remoção e disposição tomam-se de fundamental importância, diversos tipos de processos físico-químicos têm sido desenvolvidos e utilizados industrialmente. Em geral, esses processos apresentam boa eficiência, melhorando a qualidade do efluente gasoso industrial e levando algumas vezes, a produção de subprodutos como, por exemplo, o enxofre. (OPRIME, 2001).

Há várias tecnologias disponíveis para tratar odores emitidos por estações de tratamento de esgotos, manipulação de lodos e processos industriais. Os três métodos para tratamento dos odores emitidos são bioquímicos (biofiltros, biolavadores e lodos ativados), químicos (lavadores químicos, oxidação térmica, oxidação catalítica e ozonização) e 
físicos (condensação, adsorção e absorção) (BURGESS et al., 2001). Entretanto, esses processos (químicos e físicos) apresentam custos elevados por exigirem altas pressões e temperaturas, catalisadores específicos, etc.

Assim, torna-se necessário o desenvolvimento de tecnologias alternativas para contornar essa limitação econômica dos processos convencionais. Como exemplo, pode ser citado um processo de natureza biotecnológica, que tem como característica básica, a metabolização do $\mathrm{H}_{2} \mathrm{~S}$ por alguns microrganismos. Dentre os microrganismos capazes de oxidar o $\mathrm{H}_{2} \mathrm{~S}$, destacam-se as espécies autotróficas do gênero Thiobacillus, as quais oxidam formas reduzidas de enxofre (incluindo o $\mathrm{H}_{2} \mathrm{~S}$ ) como fonte energética para seu crescimento (OPRIME, 2001).

A escolha de uma única tecnologia ou a combinação de tecnologias vai depender de alguns fatores como; características de operação e capacidade de manutenção, objetivos do tratamento, fluxo de impurezas, padrão de carregamento do contaminante e as características e concentrações dos odores no ar (BURGESS et al., 2001).

O processo básico para a determinação da eficiência de remoção por biofiltração foi compreendido qualitativamente no fim dos anos 60. Daí até as proximidades da década de 80, a biofiltração foi gradativamente utilizada na Alemanha para controlar a emissão de VOCs e poluentes tóxicos na fase gasosa emitidos pelas mais variadas indústrias (MAIA, 2003).

No Brasil, há poucos estudos relacionados ao tratamento biológico de efluentes gasosos contendo substâncias tóxicas e/ou de odor desagradável evidenciando assim a necessidade do desenvolvimento e aprimoramento de tecnologias capazes de degradar eficientemente essas correntes, avaliando-se as possibilidades e viabilidades desses processos.

O Departamento de Engenharia Química da Universidade Federal da São Carlos (DEQ/UFSCar) e o Departamento de Hidráulica e Saneamento na Escola de Engenharia de São Carlos da Universidade de São Paulo (SHS/EESC/USP) têm contribuído para o aprimoramento das tecnologias e métodos de tratamento gases e efluentes gasosos. Especificamente no Laboratório de Controle Ambiental II (LCA 2) do DEQ/UFSCar foram realizadas pesquisas na área de biofiltração, estas pesquisas testaram alguns meios suportes 
com culturas puras. Visando um aprimoramento e um aumento da estabilidade dos sistemas de biofiltração desenvolvidos anteriormente, esta pesquisa teve como objetivos gerais, utilizar um consórcio de microrganismos aeróbios provenientes de um sistema de lodos ativados para aumentar a eficiência e a estabilidade do biofiltro, aumentar progressivamente a concentração de $\mathrm{H}_{2} \mathrm{~S}$ até concentrações superiores as anteriormente trabalhadas, utilizando como meio suporte a espuma de poliuretano. 


\section{OBJETIVOS}

O presente trabalho propõe aprimorar uma unidade de biofiltração para o tratamento de efluentes gasosos contendo sulfeto de hidrogênio. A técnica de tratamento de gases tóxicos em biofiltros não apresenta muitos estudos ou aplicações no país e, sendo assim, a presente proposta tem os seguintes objetivos:

a) Desenvolver e aprimorar uma unidade experimental de biofiltração para estudar a depuração de uma corrente gasosa contendo $\mathrm{H}_{2} \mathrm{~S}$ utilizando como material suporte para fixação dos microrganismos a espuma de poliuretano;

b) Analisar a fluidodinâmica do leito de espuma de poliuretano através de ensaios de perda de carga em função da vazão de ar e da umidade do leito;

c) Analisar o desempenho do biofiltro na depuração do $\mathrm{H}_{2} \mathrm{~S}$ com o aumento progressivo da concentração de entrada. 


\section{REVISÃO BIBLIOGRÁFICA}

A preocupação com a poluição atmosférica teve seu marco histórico com a promulgação do "Clean Air Act” em 1970 e a partir desta década ocorreu o grande impulso tanto no desenvolvimento de equipamentos e tecnologias de controle de poluição do ar como também na criação de programas e legislações relacionados ao controle deste tipo de poluição (HORIKAWA, 2001).

Através de estudos sobre a tolerância de organismos a estes e outros componentes tóxicos elaboraram-se tabelas com os limites de tolerância do corpo humano a cada poluente. Um exemplo são os valores limites de tolerância (Threshold Limit Values - TLV) publicado pela American Conference of Governamental Industrial Hygienists (ACGIH) que, de acordo com Macintyre (1990), indicam a concentração média de substâncias suspensas ou dispersas no ar de um certo ambiente de trabalho, em um determinado intervalo de tempo, e que representam condições para as quais pode-se presumir com certa segurança que os trabalhadores expostos a esse ar não manifestarão nenhum efeito adverso em seu organismo. Segundo Macintyre (1990), os valores conhecidos de limites de tolerância são:

a) TLV-TWA (Threshold Limit Value - Time Weighted Average): corresponde a concentrações ponderadas pelo tempo, para uma jornada de 8 horas e uma semana de trabalho de 40 horas e para as quais os trabalhadores podem ser expostos repetidamente, dia após dia, sem efeito adverso.

b) TLV - STEL (Threshold Limit Value - Short Term Exposure Limit): corresponde a concentração para a qual os trabalhadores podem ser expostos continuadamente, por um curto intervalo de tempo, sem sofrerem efeitos adversos. Um STEL corresponde à concentração durante um intervalo de tempo de 15 minutos e que não deve ser excedida em nenhum tempo durante o dia, supondo que a concentração ponderada diária esteja dentro dos padrões dos limites TLV - TWA. As exposições correspondentes ao STEL não devem exceder 4 vezes ao dia e deve haver um intervalo de pelo menos 60 minutos entre duas exposições sucessivas ao STEL.

c) TLV - C (Threshold Limit Value -Ceiling): é a concentração que não deve ser excedida em nenhum momento da jornada de trabalho, correspondendo assim, a um limite superior. 
A Tabela 1 apresenta os limites de exposição de alguns gases.

TABELA 1 - Limites de exposição de gases e vapores tóxicos

Gás

Características

Limites de Exposição

TLV-TWA TLV-STEL

\begin{tabular}{|c|c|c|c|}
\hline $\begin{array}{l}\text { Gás sulfídrico } \\
\qquad\left(\mathrm{H}_{2} \mathrm{~S}\right)\end{array}$ & $\begin{array}{l}\text { Odor forte, semelhante ao ovo podre, } \\
\text { produz dióxido de enxofre e água na } \\
\text { combustão completa e enxofre livre e } \\
\text { água na incompleta (oxigênio }\end{array}$ & $10 \mathrm{ppm}$ & $15 \mathrm{ppm}$ \\
\hline & insuficiente), percepção humana 0,5 ppb. & & \\
\hline Amônia $\left(\mathrm{NH}_{3}\right)$ & $\begin{array}{l}\text { Odor irritante e penetrante, percepção } \\
\text { humana acima de } 0,5 \mathrm{ppm}\end{array}$ & $25 \mathrm{ppm}$ & $38,9 \mathrm{ppm}$ \\
\hline $\begin{array}{c}\text { Dióxido de } \\
\text { enxofre }\left(\mathrm{SO}_{2}\right)\end{array}$ & $\begin{array}{l}\text { Odor forte e sufocante, percepção } \\
\text { humana acima de } 0,8 \mathrm{ppm}\end{array}$ & $2 \mathrm{ppm}$ & $3,82 \mathrm{ppm}$ \\
\hline
\end{tabular}

A exposição ao ar contendo mais que 1000 ppm de gás sulfídrico resulta em morte rápida devido à asfixia e paralisia do sistema nervoso central. Os sinais da exposição aguda são a taquicardia ou braquicardia (EPA, 2000). Um dos efeitos crônicos do envenenamento por $\mathrm{H}_{2} \mathrm{~S}$ é a debilidade geral (MANAHAN, 1994). A exposição a 100 ppm por curto período de tempo causa perda de sensibilidade do olfato, além de edema e inflamação da conjuntiva (LIPTÁK, 1974). A exposição menos intensa provoca, em geral, tontura, náusea, diarréia, gastrite, dor de cabeça e danos neurológicos (inclusive polineurite). Não há evidencias que a exposição repetida resulte em efeitos cumulativos (HORIKAWA, 2001).

A implantação de sistemas de controle da poluição podem ser utilizados tanto na melhoria das condições do ambiente de trabalho, quanto na recuperação de gases de alto valor agregado, podendo também ser empregados para aumentar a vida útil dos equipamentos da própria indústria quando os gases possuem características corrosivas.

\subsection{Ciclo do enxofre}

Os compostos voláteis sulfurosos, por estarem entre os principais compostos presentes em efluentes líquidos e gasosos, têm sido amplamente estudados. 
As fontes antrópicas somam por volta de 1/3 do total de emissões de compostos sulfurosos na atmosfera. Estima-se que o lançamento anual desses compostos por fontes antrópicas somam um total de $63.10^{6}$ toneladas de enxofre por ano, sendo que $93 \%$ dessas fontes são emitidas no hemisfério norte. O total emitido por todas as fontes naturais é de aproximadamente 128 megatoneladas por ano. A maior parte desses compostos é liberada em forma de $\mathrm{H}_{2} \mathrm{~S}$ pela deterioração da matéria orgânica marinha e terrestre (WILLIAMSON, 1973).

Outra fonte de enxofre atmosférico é o sulfato liberado na evaporação oceânica. Há um ciclo continuo do enxofre em forma de gases e vapores pela atmosfera que tem origem terrestre e marinha, como ilustrado na Figura 1.

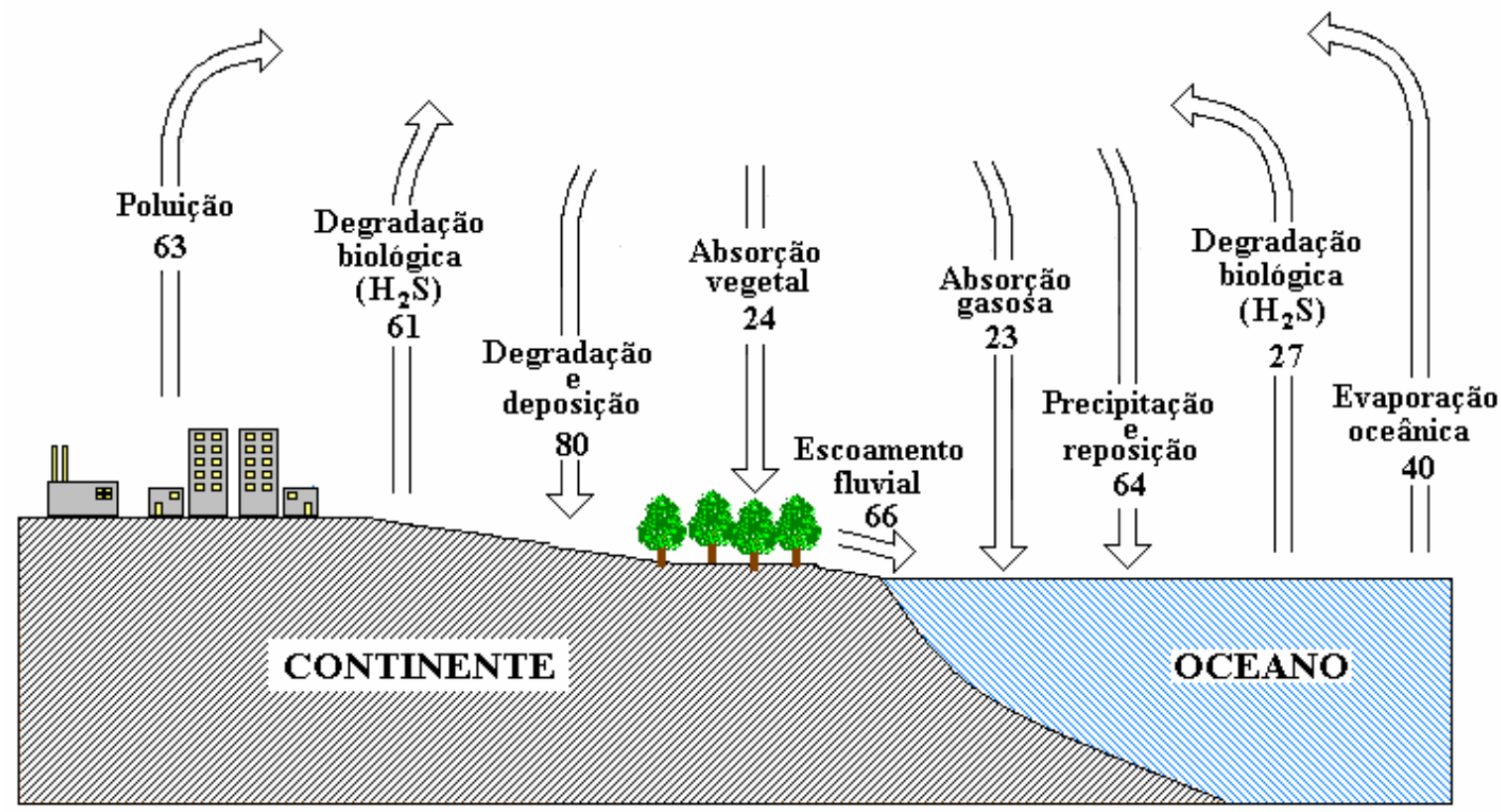

Figura 1. Circulação do enxofre no meio ambiente. Os números mostram os montantes do enxofre liberado em cada processo expresso em megatoneladas por ano. Fonte: WILLIAMSON, 1973.

$\mathrm{Na}$ baixa atmosfera, o $\mathrm{H}_{2} \mathrm{~S}$ é oxidado em um dia ou dois a $\mathrm{SO}_{2}$, aparentemente pela pequena concentração de ozônio o qual é normalmente presente, essa reação pode ser acelerada há poucas horas através do smog fotoquímico. Oxidações posteriores irão converter o $\mathrm{SO}_{2}$ em acido sulfúrico ou $\left(\mathrm{NH}_{4}\right)_{2} \mathrm{SO}_{4}$ (WILLIAMSON, 1973).

O gás sulfídrico na atmosfera é oxidado a dióxido de enxofre, segundo Manahan (1994) a reação de oxidação ocorre de acordo com a eq. (1).

$$
\mathrm{H}_{2} \mathrm{~S}+3 / 2 \mathrm{O}_{2} \rightarrow \mathrm{SO}_{2}+\mathrm{H}_{2} \mathrm{O}
$$


A oxidação química do $\mathrm{H}_{2} \mathrm{~S}$ em meio líquido por $\mathrm{O}_{2}$ chega a ser 75 vezes mais lenta que em meio gasoso para concentrações de sulfeto de até $10 \mathrm{mg} . \mathrm{L}^{-1}$ e cerca de seis vezes mais lenta para concentrações de sulfeto acima de 600 mg.L -1 $^{-1}$ em pH 8 (BUISMAN et al., 1990).

Os processos microbiológicos para a remoção de compostos sulfurosos são baseados no ciclo biológico do enxofre apresentado na Figura 2.

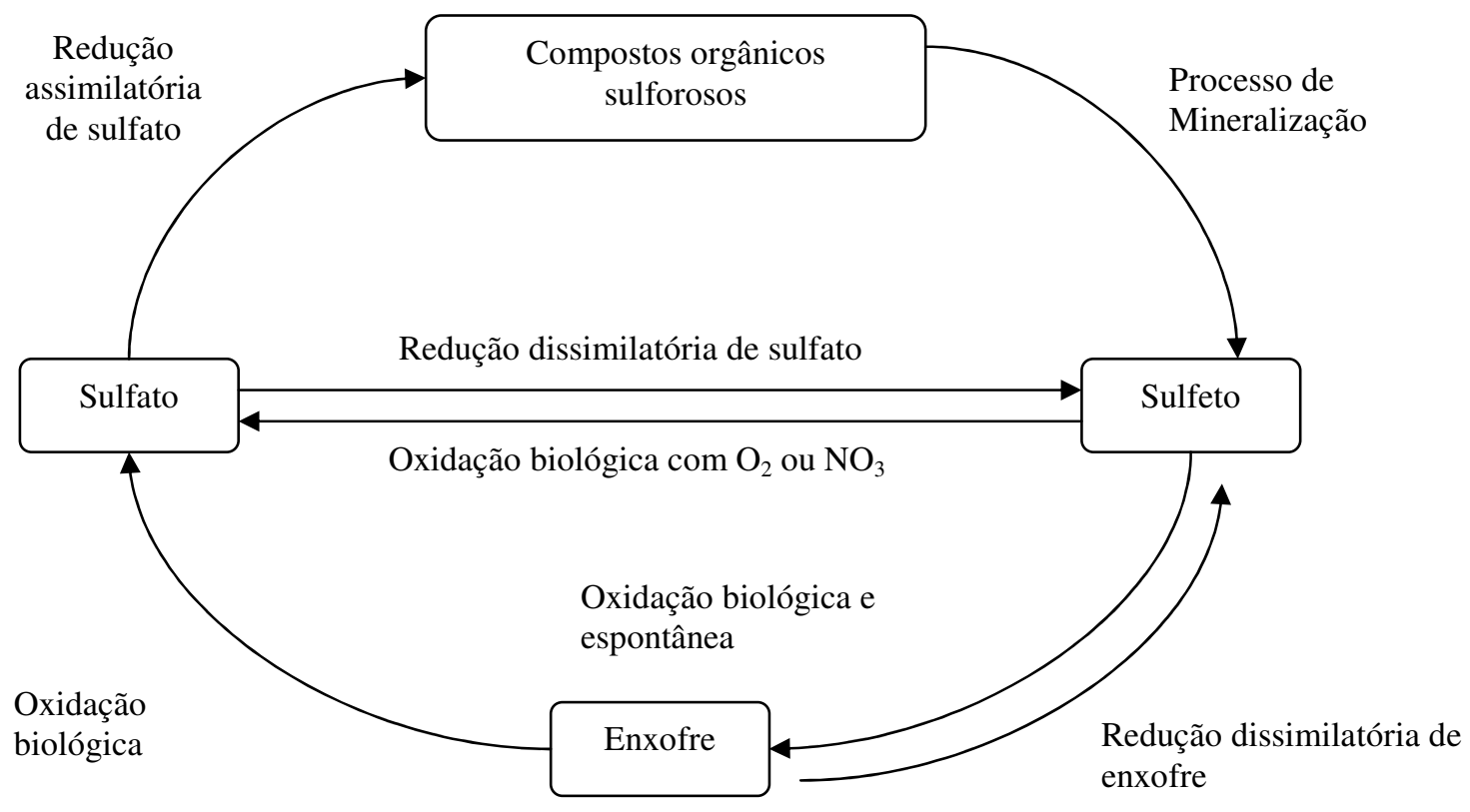

Figura 2. Ciclo biológico do enxofre

O ciclo possui um lado oxidativo e um redutivo, os quais em ecossistemas naturais devem estar em equilíbrio.

No lado redutivo a função do sulfato e do enxofre é a de aceptor de elétrons na rota metabólica utilizada por uma grande variedade de bactérias anaeróbias redutoras de sulfato (JASSEN et al., 1999).

No lado oxidativo do ciclo, os compostos reduzidos de enxofre servem como doadores de elétrons para as bactérias anaeróbias fototróficas ou promovem o aumento de energia para as bactérias redutoras de sulfato.

No principio, dois diferentes processos biotecnológicos podem ser distinguidos para a remoção do $\mathrm{H}_{2} \mathrm{~S}$. 
Primeiramente, as bactérias do gênero Chlorobiaceae e Chromatiaceae, catalisam sob condições anaeróbias, a reação fotossintética de Van Niel, como mostrado na eq. 2.

$$
2 \mathrm{nH}_{2} \mathrm{~S}+\mathrm{nCO}_{2} \rightarrow 2 \mathrm{nS}^{0}+\left(\mathrm{CH}_{2} \mathrm{O}\right)_{\eta}+\mathrm{nH}_{2} \mathrm{O}
$$

Em seguida, a oxidação do sulfeto a enxofre elementar (eq. 3) ou sulfato (eq. 4) pelo uso de bactérias quimiolitoautotróficas pertencentes ao gênero Thiobacillus é frequentemente descrito sob condições de limitações de oxigênio em bioreatores. Os Thiobacillus conseguem competir com sucesso com a oxidação química do sulfeto por causa de sua grande afinidade por estes compostos.

As equações 3 e 4 podem ocorrer em sistemas aeróbios removendo sulfeto (JANSSEN et al., 1999).

$$
\begin{array}{ll}
2 \mathrm{HS}^{-}+\mathrm{O}_{2} \rightarrow 2 \mathrm{~S}^{0}+2 \mathrm{OH}^{-} & \Delta \mathrm{G}^{\circ}=-169.35 \mathrm{kJmol}^{-1} \\
2 \mathrm{HS}^{-}+4 \mathrm{O}_{2} \rightarrow 2 \mathrm{SO}_{4}^{2-}+2 \mathrm{H}^{+} & \Delta G^{\circ}=-732.58 \mathrm{kJmol}^{-1}
\end{array}
$$

\subsection{Tratamento de efluentes gasosos}

São quatro os processos mais empregados para se reduzir a toxicidade e o odor proveniente de gases e vapores industriais: adsorção, absorção (seguida ou não de reação química), combustão (incineração) e condensação.

Os efluentes gasosos industriais têm sido tradicionalmente tratados por processos físico-químicos, como lavadores, adsorção, condensação e oxidação. Embora as técnicas físico químicas possam remover com eficiência os compostos odorantes da corrente gasosa, dentro de certas condições, a necessidade de adição de produtos químicos diariamente e a substituição do adsorvente resulta em custo de operação relativamente alto quando comparados com técnicas de tratamento biológico (CABRAL, 2003).

O tratamento biológico de efluentes gasosos apenas se tornou uma opção efetiva e econômica nas ultimas décadas, ganhando maior atenção na Europa nos anos 90 devido a sua eficiência, custo - benefício e aceitação ambiental (KENNES \& THALASSO, 1998; BURGESS et al., 2001). 
Recentemente as pesquisas na área da biofiltração visam melhorar a concepção dos biofiltros, selecionando e testando novos materiais filtrantes mais duráveis, disponíveis e menos onerosos, podendo servir de meio ambiente biológico favorável a uma atividade microbiana intensa e eficaz para a degradação dos contaminantes do ar (CHOU \& CHENG, 1997; SMET et al., 1996; BIBEAU et al., 1997; HEITZ et al., 1997; WANG et al., 997; JORIO et al., 1998; WU et al., 1999).

$\mathrm{Na}$ Tabela 2 são fornecidos: os fundamentos, os principais equipamentos, as vantagens e desvantagens de cada processo. A título de comparação são também mostradas as características da biofiltração. 
TABELA 2 - Processos convencionais para a depuração e desodorização de gases e vapores industriais

\begin{tabular}{|c|c|c|c|c|}
\hline MÉTODO & FUNDAMENTO & $\begin{array}{c}\text { PRINCIPAIS } \\
\text { EQUIPAMENTOS }\end{array}$ & VANTAGENS & DESVANTAGENS \\
\hline ADSORÇÃO & $\begin{array}{l}\text { As moléculas dos líquidos, } \\
\text { gases ou vapores } \\
\text { (adsorvato) são retidas por } \\
\text { forças físicas (adsorção } \\
\text { física, fisissorção) ou } \\
\text { químicas (adsorção } \\
\text { química, quimiossorção) na } \\
\text { superfície de um sólido } \\
\text { (adsorvente) }\end{array}$ & $\begin{array}{l}\text { a) coluna de recheio; } \\
\text { b) leito fluidizado em } \\
\text { coluna de pratos } \\
\text { perfurados }\end{array}$ & $\begin{array}{l}\text { a) os gases ou vapores podem ser } \\
\text { reaproveitados e o leito regenerado, por } \\
\text { exemplo, com vapor d'água ou } \\
\text { nitrogênio (dessorção física). } \\
\text { b) Não há resíduos químicos quando os } \\
\text { gases ou vapores retornam ao processo; } \\
\text { c) alta eficiência de remoção com } \\
\text { carvão ativado (apolar) de vapores e } \\
\text { gases orgânicos com pouca polaridade } \\
\text { (com ou sem umidade). }\end{array}$ & $\begin{array}{l}\text { a) Os gases ou vapores adsorvidos devem ser tratados } \\
\text { se não retornarem ao processo. Comum quando o } \\
\text { resíduo contém vários compostos de difícil separação; } \\
\text { b) custos de aquisição e de manutenção relativamente } \\
\text { altos; } \\
\text { c) necessita de pré-filtros para se evitar a colmatação; } \\
\text { d) a adsorção física (fraca interação entre o adsorvato e } \\
\text { o adsorvente) requer um resfriamento do resíduo para } \\
\text { uma boa operação (em geral, abaixo de } 49^{\circ} \mathrm{C} \text { ); } \\
\text { e) o processo de adsorção química (forte interação } \\
\text { entre o adsorvato e o adsorvente) requer temperaturas } \\
\text { mais altas que } 200^{\circ} \mathrm{C} \text {. O adsorvente sólido é de difícil } \\
\text { regeneração; } \\
\text { f) os adsorventes que contém sílica adsorvem } \\
\text { preferencialmente moléculas pequenas insaturadas e } \\
\text { polares. Se operarem com gases e vapores úmidos, } \\
\text { adsorverão preferencialmente a água; } \\
\text { g) pode haver uma rápida deterioração (colmatação e } \\
\text { deformação) do adsorvente em função do número de } \\
\text { ciclos e do tipo de adsorvato. }\end{array}$ \\
\hline
\end{tabular}


TABELA 2 - Processos convencionais para a depuração e desodorização de gases e vapores (continuação)

\begin{tabular}{|c|c|c|c|c|}
\hline MÉTODO & FUNDAMENTO & $\begin{array}{l}\text { PRINCIPAIS } \\
\text { EQUIPAMENTOS }\end{array}$ & VANTAGENS & DESVANTAGENS \\
\hline ABSORÇÃO & $\begin{array}{l}\text { O componente solúvel de } \\
\text { uma fase gasosa é } \\
\text { transferido para um líquido } \\
\text { (absorvente) com } \\
\text { volatilidade pequena nas } \\
\text { condições do processo }\end{array}$ & $\begin{array}{l}\text { a) coluna de recheio; } \\
\text { b) coluna de prato; } \\
\text { c) coluna de } \\
\text { nebulização; }\end{array}$ & $\begin{array}{l}\text { a) perda de carga relativamente baixa } \\
\text { (coluna de recheio e de nebulização); } \\
\text { b) pode-se obter alta taxa de } \\
\text { transferência de massa (coluna de } \\
\text { recheio e de pratos); } \\
\text { c) custo inicial relativamente baixo; } \\
\text { d) em geral, pode-se adicionar } \\
\text { módulos para se aumentar a taxa de } \\
\text { transferência; } \\
\text { espaço requerido relativamente baixo; }\end{array}$ & $\begin{array}{l}\text { a) os gases e vapores absorvidos devem ser tratados se não } \\
\text { retornarem ao processo. Comum quando o resíduo contém vários } \\
\text { compostos de difícil separação; } \\
\text { b) custos de manutenção relativamente altos; } \\
\text { c) necessita de pré-filtros (coluna de recheio e de pratos); } \\
\text { d) pode haver canais preferenciais que reduzem o tempo de } \\
\text { detenção e a taxa de transferência de massa (coluna de recheio); } \\
\text { e) se a absorção for seguida de reação química, é comum a } \\
\text { formação de resíduos sólidos e/ou líquidos, além dos altos custos } \\
\text { de aquisição, operação e manutenção. }\end{array}$ \\
\hline COMBUSTÃO & $\begin{array}{l}\text { Os gases e vapores } \\
\text { (úmidos, inertes ou } \\
\text { combustíveis) são, com } \\
\text { suficiente temperatura, } \\
\text { tempo de contato e } \\
\text { turbulência, oxidados (com } \\
\text { ou sem catalisadores) em } \\
\text { produtos menos tóxicos, } \\
\text { idealmente em vapor } \\
\text { d'água e dióxido de } \\
\text { carbono }\end{array}$ & $\begin{array}{l}\text { a) incineradores de } \\
\text { chama direta (650 a } \\
870^{\circ} \mathrm{C} \text {; o combustível é } \\
\text { o próprio resíduo); } \\
\text { b) incineradores } \\
\text { térmicos ( } 650 \text { a } 820^{\circ} \mathrm{C} ; \\
\text { requer combustível); } \\
\text { c) incinerados } \\
\text { catalíticos (350 a } 425 \\
{ }^{\circ} \mathrm{C} ; \quad \text { requer } \\
\text { combustível); }\end{array}$ & $\begin{array}{l}\text { a) possibilidade de geração de vapor e } \\
\text { recuperação de energia; } \\
\text { b) pode remover gases, vapores e } \\
\text { pequenas partículas orgânicas; } \\
\text { c) operação simples; } \\
\text { d) custo inicial relativamente baixo } \\
\text { para pequenas unidades; } \\
\text { e) pouco espaço ocupado } \\
\text { (principalmente pelo incinerador } \\
\text { catalítico); }\end{array}$ & $\begin{array}{l}\text { a) se a combustão for incompleta, pode gerar aldeídos, ácidos } \\
\text { orgânicos, carbono e monóxido de carbono; } \\
\text { b) a incineração do gás sulfídrico produz dióxido de enxofre } \\
\text { (incineração por chama direta); } \\
\text { c) custos relativamente altos de operação (grande consumo de } \\
\text { combustível pelos incineradores térmicos e catalíticos) e } \\
\text { manutenção (catalítico); } \\
\text { d) os catalisadores (platina, óxido de cobre, cromo, vanadium, } \\
\text { níquel, cobalto) dos incineradores catalíticos estão sujeitos à } \\
\text { redução da atividade por obstrução, corrosão e envenenamento, } \\
\text { principalmente por mercúrio, chumbo, zinco, organometálicos e } \\
\text { halogêneos; } \\
\text { e) necessitam de pré-filtros para se evitar incrustações e } \\
\text { sedimentações (incineradores térmicos e catalíticos); } \\
\text { f) possibilidade de explosões provocadas muitas vezes pela baixa } \\
\text { velocidade do gás (flasback). }\end{array}$ \\
\hline
\end{tabular}

FONTE: MORAES Jr. (1991) 
TABELA 2 - Processos convencionais para a depuração e desodorização de gases e vapores industriais (continuação)

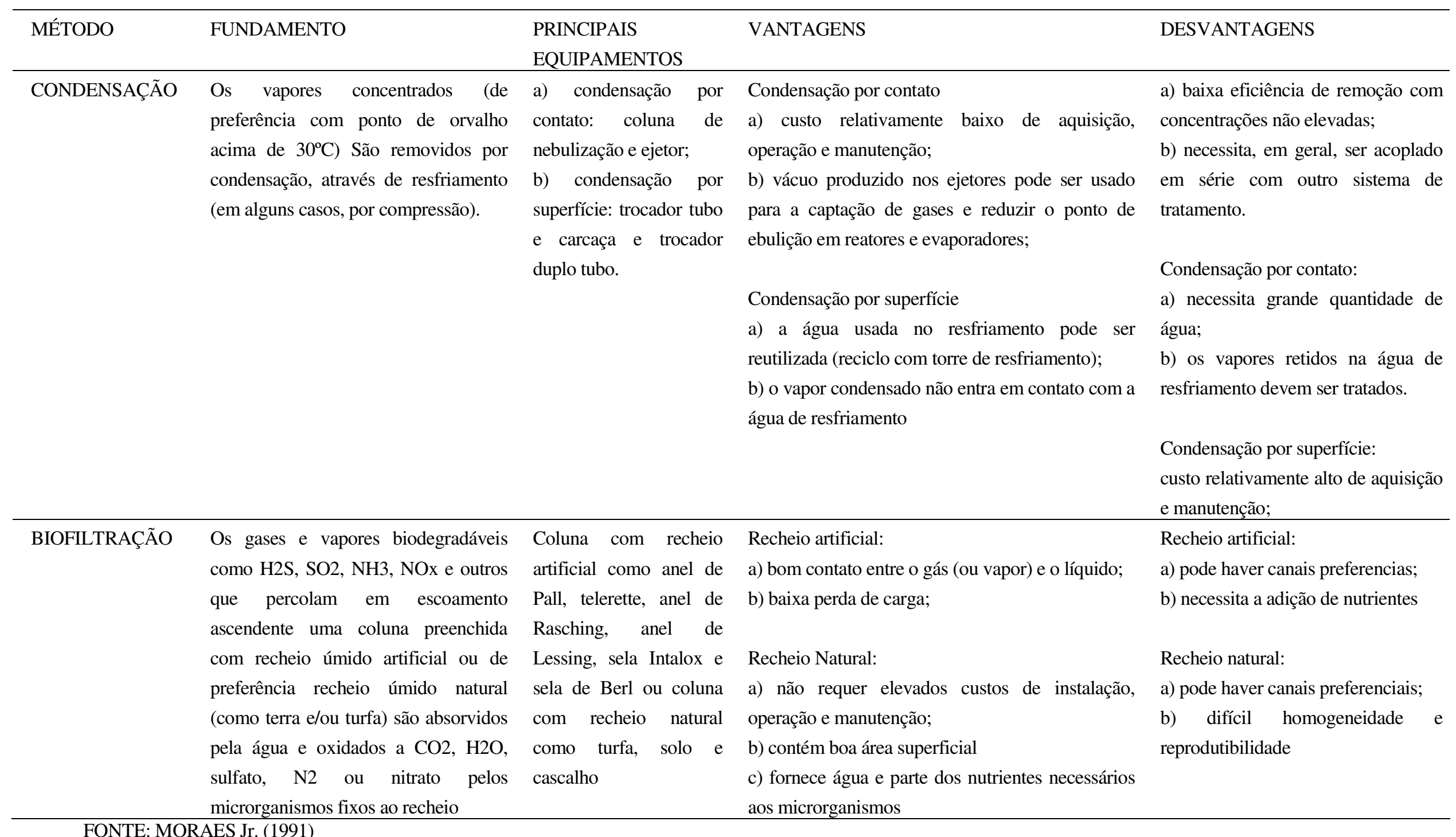




\subsection{Solubilidade dos poluentes}

A biodegradação dos contaminantes induz necessariamente uma etapa previa de transferência e de difusão dos poluentes e do oxigênio no biofilme, a solubilidade dos poluentes na água, seu coeficiente de Henry e seu coeficiente de difusão no biofilme são fatores determinantes na eficácia da biofiltração. No caso de poluentes pouco solúveis com coeficiente de Henry superior a 10 atm.L.mol ${ }^{-1}$, sua biofiltração ou outro procedimento biológico de tratamento do ar é pouco recomendado (DOLFING et al., 1993).

\subsection{Oxidação biológica de $\mathrm{H}_{2} \mathrm{~S}$}

A importância da oxidação biológica veio em questão quando Kanagawa e Mikami (1989), testaram a remoção de $\mathrm{H}_{2} \mathrm{~S}$ de uma corrente gasosa através de um meio esterilizado e outro contendo Thiobacillus thioparus, no experimento com o meio esterilizado a oxidação ocorreu, mas a taxas muito baixas, por isso os autores concluíram que a oxidação do $\mathrm{H}_{2} \mathrm{~S}$ foi feita principalmente pelos microrganismos.

Burgess et al. (2001), descobriram que para concentrações de sulfeto de hidrogênio por volta de $150 \mathrm{mg} . \mathrm{L}^{-1}$ a velocidade de oxidação biológica foi sete vezes mais rápida que a velocidade de oxidação química, e para concentrações de sulfeto abaixo de $10 \mathrm{mg} . \mathrm{L}^{-1}$, as velocidades de oxidação biológica foram 75 vezes mais rápidas que a velocidade de oxidação química.

No tratamento de efluentes gasosos, a seleção correta do tipo de microrganismo a ser utilizado é muito importante. O uso do lodo proveniente de lodos ativados é freqüentemente utilizado como inóculo em bioreatores, fazendo com que sejam necessárias menos de três semanas para a adaptação sistema (OTTENGRAF \& VAN DEN OEVER, 1983).

A duração da etapa de adaptação depende da afinidade da população microbiana frente aos poluentes. Nesse contexto o biofiltro é vantajoso em relação a outros sistemas biológicos de tratamento de efluentes gasosos, pois é caracterizado por uma fase líquida estacionária e uma flora microbiana imobilizada facilitando a adaptação de uma população aos contaminantes. 
O uso de culturas puras ganhou grande atenção, pela possibilidade de redução do tempo de partida e o aumento da eficiência das taxas de remoção no reator (SUBLETTE \& SYLVESTER, 1987).

A literatura mostra que o uso de microrganismos fototróficos, heterotróficos e autotróficos para a desulfurização de gases tem muitas vantagens sobre outros processos físico-químico, além de ser possível a recuperação de enxofre produzido biologicamente. (BURGESS et al., 2001).

O metabolismo de espécies como Thiobacillus, Thermothrix, Thiothrix, Beggiato tem sido intensivamente estudados para oxidação inorgânica (enxofre elementar, sulfeto de hidrogênio, tiosulfato) ou orgânica (metanetiol, dimetilsulfeto e dimetildisulfeto) de compostos sulfurosos (SYED et al., 2006).

As bactérias quimiotróficas utilizadas para a degradação do $\mathrm{H}_{2} \mathrm{~S}$, crescem e produzem novas células utilizando o carbono inorgânico $\left(\mathrm{CO}_{2}\right)$ como fonte de carbono e a energia química é adquirida de compostos inorgânicos reduzidos como o $\mathrm{H}_{2} \mathrm{~S}$. Na presença de fontes de carbono reduzidas (glicose, aminoacidos, etc), algumas dessas bactérias podem crescer heterotroficamente, utilizando o carbono orgânico como fonte de carbono e os compostos inorgânicos como fonte de energia (SYED et al., 2006).

As características de alguns microrganismos utilizados para degradação de compostos sulfurosos são apresentadas na Tabela 3. 
TABELA 3 - Características de alguns microrganismos utilizados na degradação de $\mathrm{H}_{2} \mathrm{~S}$ ou compostos sulfurosos.

\begin{tabular}{|c|c|c|c|c|c|c|c|c|c|}
\hline Condições & $\begin{array}{l}\text { Thiobacillus } \\
\text { ferrooxidans }\end{array}$ & $\begin{array}{l}\text { Thiobacillus } \\
\text { thiooxidans }\end{array}$ & $\begin{array}{c}\text { Thiobacillus } \\
\text { novellus }\end{array}$ & $\begin{array}{c}\text { Thiobacillus } \\
\text { thioparus }\end{array}$ & $\begin{array}{l}\text { Microrganismos } \\
\text { Thiobacillus } \\
\text { denitrificans } \\
\end{array}$ & $\begin{array}{c}\text { Thermothrix } \\
\text { azorensis }\end{array}$ & Thiothix nivea & $\begin{array}{l}\text { Thioalkalispira } \\
\text { microaerophila }\end{array}$ & $\begin{array}{c}\text { Thiomicrospra } \\
\text { frísia }\end{array}$ \\
\hline $\begin{array}{l}\mathrm{pH} \text { de } \\
\text { Crescimento }\end{array}$ & - & $0,5-6,0$ & $5,7-9,0$ & $5-9$ & - & $6,0-8,5$ & $6,0-8,5$ & $8-10,4$ & $4,2-8,5$ \\
\hline pH Ótimo & $1,3-4,5$ & $2,0-3,5$ & 7,0 & 7,5 & $6,8-7,4$ & $7,0-7,5$ & - & 10 & 6,5 \\
\hline $\begin{array}{l}\text { Temperatura } \\
\text { de cresci- } \\
\text { mento }\left({ }^{\circ} \mathrm{C}\right)\end{array}$ & $10-37$ & $10-37$ & $10-37$ & - & - & $\begin{array}{c}63-86 \\
\text { (termofílica) }\end{array}$ & - & - & $3,5-39$ \\
\hline $\begin{array}{l}\text { Temperatura } \\
\text { Ótima }\left({ }^{\circ} \mathrm{C}\right)\end{array}$ & $30-35$ & $28-30$ & 30 & 28 & $28-32$ & $76-78$ & $15-30$ & - & $32-35$ \\
\hline $\begin{array}{l}\text { Forma e } \\
\text { tamanho }\end{array}$ & $\begin{array}{c}\text { Bacilo } \\
0,5-1 \mu \mathrm{m}\end{array}$ & $\begin{array}{c}\text { Bacilo } \\
0,5 \times 1,1-2 \\
\mu \mathrm{m}\end{array}$ & $\begin{array}{c}\text { Bacilo } \\
0,4-0,8 \times 0,8- \\
2 \mu \mathrm{m}\end{array}$ & $\begin{array}{c}\text { Bacilo } \\
0,9-1,8 \mu \mathrm{m}\end{array}$ & $\begin{array}{c}\text { Bacilo } \\
0,5 \times 1-3 \mu \mathrm{m}\end{array}$ & $\begin{array}{c}\text { Bacilo } \\
0,3-0,8 \times 2-5 \\
\mu \mathrm{m}\end{array}$ & $\begin{array}{c}\text { Bacilo } \\
0,7-2,6 \times 0,7- \\
5 \mu \mathrm{m}\end{array}$ & $\begin{array}{c}\text { Espirilo } \\
0,3-0,45 \times 1- \\
4 \mu \mathrm{m}\end{array}$ & $\begin{array}{c}\text { Bastonetes } \\
\text { curvos } \\
0,3-0,5 \times 1- \\
2,7 \mu \mathrm{m}\end{array}$ \\
\hline Nível trófico & $\begin{array}{l}\text { Quimiauto- } \\
\text { trófica } \\
\text { Obrigatória }\end{array}$ & $\begin{array}{c}\text { Quimiautotró- } \\
\text { fica } \\
\text { obrigatória }\end{array}$ & $\begin{array}{l}\text { Quimiauto- } \\
\text { trófica } \\
\text { facultativa }\end{array}$ & $\begin{array}{l}\text { Quimiauto- } \\
\text { trófica } \\
\text { obrigatória }\end{array}$ & $\begin{array}{l}\text { Quimiauto- } \\
\text { trófica } \\
\text { obrigatória }\end{array}$ & $\begin{array}{l}\text { Quimiauto- } \\
\text { trófica } \\
\text { obrigatória }\end{array}$ & $\begin{array}{l}\text { Quimiauto- } \\
\text { trófica } \\
\text { facultativa }\end{array}$ & $\begin{array}{l}\text { Quimiauto- } \\
\text { trófica } \\
\text { obrigatória }\end{array}$ & $\begin{array}{l}\text { Quimiauto- } \\
\text { trófica } \\
\text { obrigatória }\end{array}$ \\
\hline $\begin{array}{l}\text { Fontes de } \\
\text { energia }\end{array}$ & $\begin{array}{c}\text { Íons ferrosos } \\
\text { e compostos } \\
\text { sulfurosos } \\
\text { reduzidos }\end{array}$ & $\begin{array}{l}\text { Sulfeto de } \\
\text { Hidrigênio, } \\
\text { plitionatos } \\
\text { enxofre } \\
\text { elementar. }\end{array}$ & $\begin{array}{c}\text { Sulfeto de } \\
\text { Hidrogênio, } \\
\text { metil } \\
\text { mercaptanas, } \\
\text { dimetil sulfeto, } \\
\text { dimetil disulfeto }\end{array}$ & $\begin{array}{l}\text { Tiosulfato, } \\
\text { sulfeto }\end{array}$ & $\begin{array}{l}\text { Tiosulfato, } \\
\text { tetrationato, } \\
\text { tiocianato, } \\
\text { sulfeto, enxofre } \\
\text { elementar. }\end{array}$ & $\begin{array}{l}\text { Tiosulfato, } \\
\text { tetrationato, } \\
\text { sulfeto de } \\
\text { hidrogênio, } \\
\text { enxofre } \\
\text { elementar. }\end{array}$ & $\begin{array}{c}\text { Enxofre } \\
\text { inorgânico, } \\
\text { compostos } \\
\text { orgânicos } \\
\text { simples, açúcar. }\end{array}$ & $\begin{array}{l}\text { Sulfeto, } \\
\text { polisulfeto, } \\
\text { enxofre } \\
\text { elementar, } \\
\text { tiosulfato }\end{array}$ & $\begin{array}{l}\text { Tiosulfato, } \\
\text { tetrationato, } \\
\text { enxofre, } \\
\text { sulfeto }\end{array}$ \\
\hline $\begin{array}{l}\text { Necessidade } \\
\text { de oxigênio }\end{array}$ & $\begin{array}{l}\text { Facultativo } \\
\text { Anaeróbio* }\end{array}$ & Aeróbio estrito & Aeróbio estrito & Aeróbio estrito & $\begin{array}{l}\text { Facultativo } \\
\text { Anaeróbio** }\end{array}$ & Aeróbio estrito & $\begin{array}{l}\text { Aeróbio estrito } \\
\text { e } \\
\text { microaerofílico }\end{array}$ & $\begin{array}{l}\text { Aeróbio estrito e } \\
\text { microaerofílico }\end{array}$ & $\begin{array}{l}\text { Aeróbio } \\
\text { estrito }\end{array}$ \\
\hline $\begin{array}{l}\text { Deposito de } \\
\text { enxofre }\end{array}$ & - & - & - & Extracelular & - & Intracelular & Intracelular & Intracelular & Extracelular \\
\hline Referência & $\begin{array}{l}\text { Colorado } \\
\text { School of } \\
\text { mines }\end{array}$ & $\begin{array}{l}\text { TAKANO et al. } \\
\text { (1997) }\end{array}$ & $\begin{array}{c}\text { CHA et al. } \\
\text { (1999); KELLY } \\
\text { et al. }(2000)\end{array}$ & $\begin{array}{l}\text { VLASCEANU } \\
\text { et al. (1997) }\end{array}$ & $\begin{array}{c}\text { KELLY e } \\
\text { WOOD (2000) }\end{array}$ & $\begin{array}{l}\text { ODINTSOVA et } \\
\text { al. (1996) }\end{array}$ & $\begin{array}{l}\text { HOWARTH et } \\
\text { al. (1999); } \\
\text { PRESCOTT et } \\
\text { al. (2003) }\end{array}$ & $\begin{array}{c}\text { SOROKIN et al. } \\
\text { (2002) }\end{array}$ & $\begin{array}{l}\text { BRINKHOFF } \\
\text { et al. (1999) }\end{array}$ \\
\hline
\end{tabular}

*Sob condições anaeróbias o Thiobacillus ferrooxidans pode crescer no enxofre elementar utilizando o ferro iônico como um aceptor.

**Cresce como um anaeróbio quimiautotrófico utilizando nitrato, nitrito ou óxidos nitroso.

Fonte: SYED et al., (2006) 
A purificação de efluentes gasosos contendo um baixo número de poluentes pode ser efetuada através de uma população limitada a algumas espécies microbianas para acelerar a partida do biofiltro com culturas puras ou lodos ativados, previamente adaptados aos poluentes. Esta prática é particularmente eficaz na degradação de compostos orgânicos complexos ou recalcitrantes, como hidrocarbonetos halogenados ou aromáticos, que necessitam às vezes para acelerar o processo, serem co-metabolizados juntamente com outras substâncias mais facilmente degradáveis. Por outro lado, emissões gasosas poluídas simultaneamente por compostos diversos, como as que são emitidas por plantas de tratamento dos esgotos ou de compostagem, necessitam de uma população mais heterogênea capaz de utilizar várias rotas metabálicas diferenciadas, que são geralmente disponíveis nos microrganismos presentes nos lodos ativados e na compostagem (CONVERTI et al., 2001).

Os mecanismos de degradação do $\mathrm{H}_{2} \mathrm{~S}$ em biofiltros são muito complexos, pois eles envolvem tanto limitações físicas como a taxa de transferência do $\mathrm{H}_{2} \mathrm{~S}$ da fase gasosa para a fase liquida (biofilme), quanto, mudanças químicas dependendo da atividade microbiana (ELIAS et al., 2002).

Acredita-se que os compostos odorantes, são removidos por adsorção e ou diluição na fase líquida e pela combinação de oxidação química e biológica (OSTOJIC et al., 1992).

A biodegradação na presença do oxigênio é realizada por uma população microbiana aeróbia. No momento das reações de biodegradação, o oxigênio é transferido para a fase líquida ao nível do biofilme, onde é utilizado pelos microrganismos. A baixa solubilidade do oxigênio na água limita sua transferência para o biofilme, mas devido à elevada concentração de oxigênio no ar e a espessura mais fina do biofilme, supõe-se que o oxigênio seja transferido em quantidades suficientes (JORIO \& HEITZ, 1999; HODGE \& DEVINNY, 1995).

A Tabela 4 resume os mecanismos de remoção que podem ocorrer em um reator com leito de lodo ativado. 
TABELA 4 - Mecanismos responsáveis pela remoção de compostos odorantes em biofiltros com lodo ativado

Método de remoção Comentários

Os compostos odorantes são transferidos da fase gasosa para a massa líquida. Compostos solúveis em água como $\mathrm{o} \quad \mathrm{H}_{2} \mathrm{~S}$, podem ser

Absorção prontamente absorvidos no líquido. A massa de material transferido é em função da área superficial das bolhas, o tempo de contato e o coeficiente de difusividade.

Adsorção

Alguns compostos com alto peso molecular e baixa solubilidade podem ser fisicamente adsorvidos no floco biológico.

Os compostos odorantes relativamente mais quentes que são

Condensação transferidos para a fase líquida, a menores temperaturas vão resultar em condensação dos compostos orgânicos voláteis.

Devido a alta concentração de microrganismos aeróbios ativos, a

Oxidação Biológica oxidação biológica é responsável por uma significante conversão dos compostos odorantes que inicialmente são absorvidos pelo liquido, adsorvido pelos flocos ou condensado.

Fonte: BURGESS et al. (2001)

Buisman et al. (1990) propuseram um mecanismo de degradação, onde o sulfato era o produto final da remoção aeróbia de sulfeto pelo Thiobacillus sp. Estes autores determinaram também que o enxofre elementar era apenas um produto intermediário do processo como um todo.

Nos sistemas que removem biologicamente $\mathrm{o}_{2} \mathrm{~S}$, a oxidação fornece o suplemento de energia necessário para as células e essas por sua vez produzem compostos menos odoríficos, conforme as equações 5 e 6 (OYARZÚN et al., 2003).

$$
\begin{aligned}
& 2 \mathrm{HS}^{-}+\mathrm{O}_{2} \rightarrow 2 \mathrm{~S}^{0}+2 \mathrm{OH}^{-} \\
& 2 \mathrm{~S}^{0}+3 \mathrm{O}_{2} \rightarrow 2 \mathrm{SO}_{4}^{-2}+2 \mathrm{H}^{+}
\end{aligned}
$$

Chung et al. (1996a) descobriram que o mecanismo de degradação por Thiobacillus thioparus $\mathrm{CH} 11$ variava para diversas concentrações de $\mathrm{H}_{2} \mathrm{~S}$, mostrando que, quando o reator é submetido a menores concentrações de alimentação $(5 \mathrm{ppm})$, a maior parte do sulfeto se torna sulfato e, a maiores concentrações (60 ppm), a maior parte do sulfeto se torna enxofre elementar.

As equações 7 e 8 mostram as porcentagens e os compostos encontrados por Chung et al. (1996a) para as diferentes concentrações de alimentação.

Para altas concentrações: 


$$
\mathrm{H}_{2} \mathrm{~S} \rightarrow 0,25 \mathrm{SO}_{4}^{2-}+0,72 \mathrm{~S}+0,02 \mathrm{SO}_{3}^{2-}+0,005 \mathrm{~S}^{2-}
$$

Para baixas concentrações:

$$
\mathrm{H}_{2} \mathrm{~S} \rightarrow 0,75 \mathrm{SO}_{4}^{2}+0,18 \mathrm{~S}+0,05 \mathrm{SO}_{3}^{2}+0,007 \mathrm{~S}^{2}
$$

\subsection{Biotecnologias para remoção de $\mathrm{H}_{2} \mathrm{~S}$}

Em todos os tipos de reatores biológicos, dois processos principais ocorrem. Primeiro, os poluentes são transferidos da fase gasosa para o meio líquido ou para um biofilme, e segundo, os poluentes são degradados pelos microrganismos que estão presentes no meio liquido ou no biofilme (CABRAL, 2003).

Os microrganismos são um importante fator nos ciclos biogeoquímicos, mineralizando biopolímeros e compostos xenobióticos (LIE et al., 1998).

Segundo Brauer (1986), o processo de transformação pode ser expresso simplificadamente pela eq. 9:

Gases Odorantes $+\mathrm{O}_{2} \stackrel{\text { bactéria }}{\longrightarrow}$ Células Bacterianas $+\mathrm{CO}_{2}+\mathrm{H}_{2} \mathrm{O}$

Quando providas com uma fonte de oxigênio, as bactérias consomem as espécies iônicas de sulfeto e a oxidam a espécies sulfurosas não odorantes. Este mecanismo sugere uma cultura biológica adaptada à degradação de compostos sulfurosos, como as encontradas em um sistema de lodos ativados. Estas conseguem converter o sulfeto em espécies de sulfato, não odorantes, se houver uma fonte de oxigênio (JOYCE, 1995).

Para o tratamento de efluentes gasosos, as três técnicas de biotecnologia mais utilizadas, são os biolavadores, biopercoladores e os biofiltros e se baseiam no fato de que certas espécies microbianas são capazes de degradar os poluentes orgânicos ou inorgânicos da corrente gasosa para formar produtos de oxidação tais como água, dióxido de carbono, sais minerais e o material celular necessário ao crescimento microbiano. Assim, os poluentes na fase gasosa são primeiramente transferidos para a fase liquida e servem de substrato para a flora microbiana presente no bioreator (JORIO \& HEITZ, 1999). 
A Figura 3 mostra um esquema dos sistemas mais comuns utilizados para o tratamento biológico de gases.
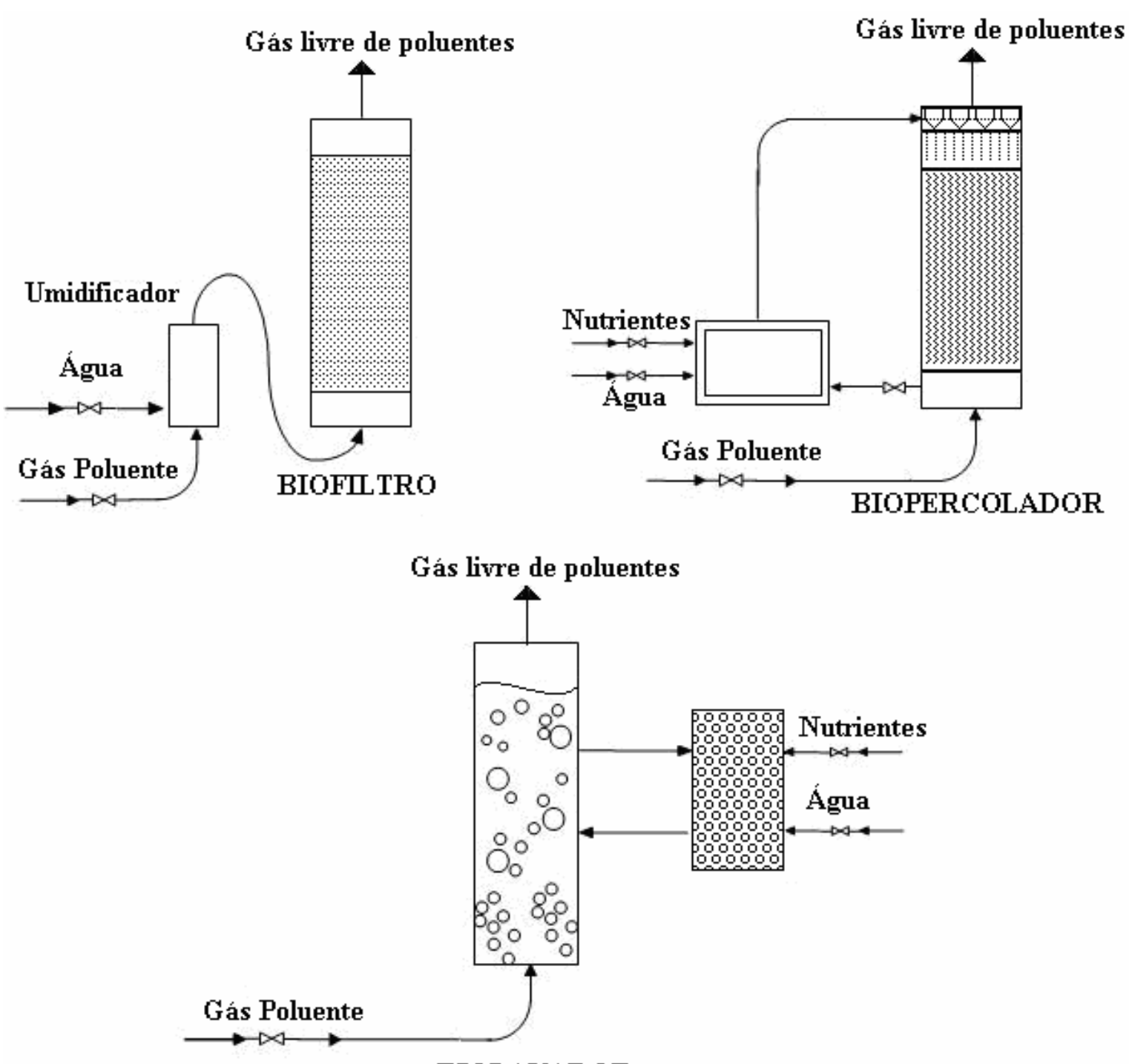

\section{BIOLAVADOR}

Figura 3. Esquema dos sistemas mais comuns de tratamento biológico de gases FONTE: EDWARDS \& NIRMALAKHANDAN (1996)

Na Tabela 5 são mostradas as vantagens e desvantagens de cada um dos tipos mais comuns de reatores biológicos. 
TABELA 5 - Vantagens e desvantagens dos reatores biológicos.

\begin{tabular}{|c|c|c|}
\hline & Vantagens & Desvantagens \\
\hline \multirow{5}{*}{ Biofiltro } & Operação Simples & $\begin{array}{l}\text { Baixo Fluxo volumétrico de } \\
\text { efluente gasoso }\end{array}$ \\
\hline & Baixos Custos de Investimento & Apenas baixas concentrações de \\
\hline & Baixo Custo de operação & poluente \\
\hline & $\begin{array}{l}\text { Degradação de menos poluentes } \\
\text { solúveis em água }\end{array}$ & $\begin{array}{l}\text { Impossível o controle do } \\
\text { processo }\end{array}$ \\
\hline & Redução satisfatória de odores & $\begin{array}{l}\text { Formação de canal preferencial } \\
\text { de fluxo é comum }\end{array}$ \\
\hline \multirow{5}{*}{ Biopercolador } & o Simples & Limitado controle do processo \\
\hline & Baixos Custos de Investimento & Formação de canais pode ser um \\
\hline & Baixo Custo de operação & problema \\
\hline & Satisfatório para contaminações & Vida limitada do leito \\
\hline & $\begin{array}{l}\text { moderadas de efluente gasoso } \\
\text { Possibilidade de adição de nutrientes }\end{array}$ & $\begin{array}{l}\text { Excesso de biomassa não } \\
\text { disponível }\end{array}$ \\
\hline \multirow{5}{*}{ Biolavador } & $\begin{array}{l}\text { Boa possibilidade de controle do } \\
\text { processo }\end{array}$ & $\begin{array}{l}\text { Alto custo de investimento } \\
\text { Altos custos operacionais }\end{array}$ \\
\hline & Alta transferência de massa & Produção de excesso \\
\hline & Satisfatório para modelagem & biomassa \\
\hline & & $\mathrm{D}$ \\
\hline & $\begin{array}{l}\text { Alta estabilidade operacional } \\
\text { Possibilidade de adição de nutrientes }\end{array}$ & $\begin{array}{l}\text { Possível entupimento na fase de } \\
\text { absorção }\end{array}$ \\
\hline
\end{tabular}

Os biolavadores fazem a absorção dos poluentes da fase gasosa para a fase liquida pelo borbulhamento do efluente gasoso em uma coluna de água; essa transferência é seguida da degradação dos compostos. A fase liquida é recirculada promovendo uma excelente limpeza dos gases com alta solubilidade. As desvantagens desse sistema dizem respeito à condição de dissolução dos poluentes. Durante o curto tempo de residência, muitos dos poluentes são voláteis e pouco solúveis em água e o crescimento da biomassa tem que ser controlado para reduzir o descarte de resíduos sólidos e para aumentar a eficiência do sistema (BURGESS et al., 2001).

Os biolavadores são constituídos de três elementos: uma coluna de transferência de gás - liquido ou absorventes, um tanque de ativação biológica, na qual se produz a degradação biológica dos poluentes solubilizados em meio mais ou menos ventilado e um decantador que permite a separação da biomassa e do líquido recirculado. (MIGAUD, 1996, apud CABRAL, 2003)

Os biolavadores são pouco utilizados em nível industrial, porém, as razões que levam a escolha desta técnica são a capacidade de absorção às flutuações de vazão ou à 
concentração dos compostos hidrossolúveis e a facilidade do controle dos parâmetros pH e densidade celular (COX \& DESHUSSES, 2000a).

O tratamento de gases através de biopercoladores consiste em utilizar a propriedade de inúmeros microrganismos a serem adsorvidos e fixos sobre os elementos de preenchimento ou sobre os suportes estruturados. Após a inoculação, o biofilme se desenvolve na superfície do suporte, podendo ter vários milímetros (LE CLOIREC et al., 1991; CABRAL, 2003)

Nos biopercoladores, a taxa de alimentação e a concentração de nutrientes são baseadas na expectativa de requerimento de nutrientes pela cultura microbiana. Os biopercoladores, geralmente, recebem menos nutrientes do que precisam estequiometricamente. Isto acontece porque os nutrientes são internamente reciclados através de células mortas, digestão de biomassa endógena e por predadores tais como protozoários e rotíferos. A limitação de nutrientes pode ser um escolha do operador na tentativa de limitar o crescimento da biomassa e colmatação do leito (COX \& DESHUSSES, 2000a).

As vantagens dos biopercoladores são o requerimento de baixo tempo de detenção do gás, maior facilidade do controle das condições operacionais ( $\mathrm{pH}$ e umidade) comparado com os biofiltros, altas eficiências de remoção e requerimento de menores espaços para serem instalados quando comparados com os biolavadores.

A biofiltração é um processo que utiliza o crescimento de microrganismos imobilizados em um meio suporte orgânico. O meio suporte orgânico atua como um suporte físico para a biomassa ativa e, em alguns casos, ele fornece nutrientes para o crescimento bacteriano. A corrente de gás poluído passa através do leito filtrante que absorve os compostos biodegradáveis voláteis e os microrganismos degradam esses compostos em compostos menos prejudiciais (VAN GROENESTIJN \& HESSELINK, 1993).

Os biofiltros apresentam-se em duas configurações: biofiltros abertos e biofiltros fechados. Os biofiltros abertos consistem tipicamente de uma determinada área de solo escavada que possui uma rede de distribuição de tubulações perfuradas, localizadas no 
fundo para aeração, circundadas com brita e com enchimento de solo ou composto (CABRAL, 2003).

Os biofiltros fechados foram desenvolvidos para resolver certos problemas como controle de temperatura e umidade do leito, sendo mais compactos e confiáveis ocupam espaços menores que os filtros abertos e são pouco afetados pelas variações climáticas, melhorando ainda mais sua estabilidade (JORIO \& HEITZ, 1999).

$\mathrm{Na}$ Tabela 6 são classificados os poluentes mais comuns removidos por biofiltração, as diferentes classes de poluentes e os diversos poluentes dentro da mesma classe caracterizam-se por uma biodegradabilidade bastante variável (CONVERTI, et al. 2001).

TABELA 6 - Principais poluentes removidos por biofiltração e sua biodegradabilidade.

\begin{tabular}{|c|c|c|c|c|}
\hline $\begin{array}{c}\text { Alta } \\
\text { Biodegradabilidade }\end{array}$ & $\begin{array}{c}\text { Boa } \\
\text { Biodegradabilidade }\end{array}$ & $\begin{array}{c}\text { Mínima } \\
\text { Biodegradabilidade }\end{array}$ & $\begin{array}{c}\text { Nula } \\
\text { Biodegradabilidade }\end{array}$ & $\begin{array}{c}\text { Incerta } \\
\text { Biodegradabilidade }\end{array}$ \\
\hline Alifáticos & Alifáticos & Alicíclicos & Halogenados & Alifáticos \\
\hline Butadieno & Hexano & Ciclohexano & 1,1,1-Tricloroetano & Acetileno \\
\hline Aromáticos & Aromáticos & Alifáticos & & Azotados \\
\hline \multirow[t]{2}{*}{$\begin{array}{l}\text { Etilbenzeno, Xileno, } \\
\text { Cresóis. }\end{array}$} & $\begin{array}{l}\text { Benzeno, Estireno, } \\
\text { Tolueno, Fenóis. }\end{array}$ & Metano, Pentano & & Isocianatos \\
\hline & & Aromáticos & & Oxigenados \\
\hline Azotados & Halogenados & $\underline{\text { Hidrocarbonetos }}$ & & Metil metacrilato \\
\hline \multirow[t]{2}{*}{ Trimetilamina } & Clorotenóis & policiclicos & & \\
\hline & & $\underline{\text { aromáticos }}$ & & Sulfurados \\
\hline Oxigenados & Azotados & & & $\underline{\text { Isoliocianatos }}$ \\
\hline Álcoois: Butanol, & $\underline{\text { Amidas }}$ & Halogenados & & \\
\hline Etanol, Metanol & Heterocíclicos: & Tetracloreto de & & \\
\hline Aldeídos: & $\underline{\text { Piridina }}$ & Carbono, & & \\
\hline Acetaldeído, & $\underline{\text { Isonitrilas }}$ & Dicloroetano, & & \\
\hline Formaldeído & Nitrilas: Acetonitrila & Diclorometano, & & \\
\hline Ésteres: Etil acetato & & Pentaclorofenol, & & \\
\hline Éteres: & Oxigenados & Percloroetileno, & & \\
\hline Tetraidrofurano & Metilisobutilcetona & tricloroetano, & & \\
\hline Cetonas: Acetona & & tricloroetileno & & \\
\hline Ácidos Orgânicos: & Sulfurados & & & \\
\hline \multirow[t]{2}{*}{ Ácido Butírico } & $\underline{\text { Heterocíclicos: }}$ & Azotados & & \\
\hline & Tiofeno & $\underline{\text { Nitrocompostos }}$ & & \\
\hline Sulfurados & $\underline{\text { Sulfocianatos }}$ & & & \\
\hline \multirow[t]{2}{*}{ Metil mercaptano } & Tioéteres: Dimetil & Oxigenados & & \\
\hline & sulforeto & Dioxana & & \\
\hline \multicolumn{5}{|l|}{ Inorgânicos } \\
\hline $\mathrm{HCl}, \mathrm{HF}, \mathrm{H}_{2} \mathrm{~S}, \mathrm{NH}_{3}$ & & Sulfurados & & \\
\hline $\mathrm{NO}\left(\right.$ exceto $\left.\mathrm{NO}_{2}\right)$, & & Disulfureto de & & \\
\hline $\mathrm{PH}_{3}, \mathrm{SiH}_{4}, \mathrm{SO}_{2}$ & & Carbono & & \\
\hline
\end{tabular}


Os procedimentos biológicos podem ser aplicados a uma grande variedade de compostos biodegradáveis, como mostrados na Tabela 6. Esses compostos fazem parte de poluentes atmosféricos, tóxicos, mal cheirosos e perigosos. Outro aspecto prático da tecnologia de biofiltração é a possibilidade de tratamento, em uma só etapa, de efluentes contaminados por diversas categorias de poluentes (JORIO \& HEITZ, 1999).

Baseado nos custos do equipamento e de operação, acredita-se que o tratamento biológico seja a opção mais econômica para tratar $\mathrm{NH}_{3}$ e $\mathrm{H}_{2} \mathrm{~S}$. As tecnologias de células imobilizadas são implantadas nos tratamentos de águas residuárias e trazem vantagens como, altos números de microrganismos, prevenção de perda de microrganismos, alta tolerância as condições ambientais e alta estabilidade operacional (CHUNG et al., 2000).

No estudo do tratamento de efluentes gasosos, CHUNG et al. (1996a) provaram o valor da tecnologia das células imobilizadas mostrando a alta eficiência de remoção (superiores a 99\%), o alto potencial de remoção $\left(33\right.$ g. $\left.\mathrm{S}^{2-} \cdot \mathrm{m}^{-3} \cdot \mathrm{h}^{-1}\right)$ e a estabilidade operacional do sistema.

\subsection{Fatores ambientais da Biofiltração}

A biofiltração é um processo complexo que inclui transferência de massa e reações químicas que são influenciados pela fluido-dinâmica do fluxo gasoso que atravessa o reator. É necessário um ambiente o mais próximo possível das condições ótimas para os microrganismos, dentre as quais a estrutura do meio suporte, a umidade, a temperatura e o pH devem ser controlados para garantir boas remoções (CONVERTI et al., 2001).

Uma distribuição uniforme da corrente gasosa na entrada do biofiltro é indispensável, pois uma distribuição não uniforme favorece caminhos preferenciais, diminuindo assim o tempo de residência.

A umidificação ocasional do leito filtrante é necessária para o controle de umidade e $\mathrm{pH}$, e para fornecer eventualmente suplementos nutritivos aos microrganismos. Esta irrigação é feita por borrifação direta (VAN GROENESTYN \& HESSLINK, 1993).

Outros equipamentos podem ser exigidos para o processo de biofiltração. No caso de emissões gasosas carregadas de partículas sólidas, é necessário retira-las previamente 
através de um equipamento suplementar para evitar a colmatação do leito filtrante (ciclone, por exemplo). No caso de gases frios $\left(\mathrm{T}<10^{\circ} \mathrm{C}\right)$, é necessário elevar a temperatura para ajustá-la àquela favorável à atividade microbiana, antes de introduzi-los no biofiltro.

O resfriamento dos efluentes gasosos muito quentes é realizado durante a etapa de umidificação, enquanto que o aquecimento dos gases é sempre realizado por injeção de vapor quente no biofiltro (VAN LITH et al., 1997).

\subsubsection{Necessidades nutricionais dos biofiltros}

Como todo organismo vivo, os microrganismos têm necessidades nutricionais para seu crescimento e funcionamento normal. O nitrogênio e o fósforo são elementos nutritivos essenciais (VAN GROENESTIJIN \& HESSLINK, 1993). O nitrogênio constitui perto de $15 \%$ do peso seco de uma célula, sendo um elemento indispensável para a síntese dos ácidos nucléicos e das proteínas das células microbianas.

O nitrogênio e o fósforo podem ser ajustados sob a forma de fosfato de amônia, ou ainda, de uma mistura de sais tais como o sulfato de amônio, nitrato de amônia e o cloreto de amônio, fosfatos de potássio, fosfato de sódio e fosfato de cálcio. Heitz et al. (1994) sugerem que a atividade metabólica dos microrganismos em sistemas de biofiltração seja estimulada pela presença de elementos nutritivos em certas proporções como $\mathrm{C} / \mathrm{N} / \mathrm{P}$ 100:15:3 e C/N/P 100:5:1.

\subsection{2. $\quad$ O meio suporte na biofiltração}

O recheio do biofiltro é o suporte dos microrganismos, que aderem à superfície das partículas sólidas e tomam os nutrientes necessários à sua atividade. As características físicas e mecânicas das partículas de material suporte têm influencia direta sobre a estrutura física do leito e sua estabilidade e condicionam a transferência dos contaminantes e do oxigênio da fase gasosa para o biofilme. O tipo de material filtrante é um parâmetro importante do procedimento (CORSI \& SEED 1995; SMITH et al., 1996; WANG et al., 1997; WU et al., 1998).

O meio suporte tem que ser capaz de garantir a estabilidade do leito e as condições ótimas para o desenvolvimento dos microrganismos. Os materiais mais utilizados são os que oferecem uma grande área superficial específica, uma eficaz retenção de água e 
nutrientes e uma particular capacidade de imobilização. Para prevenir o aumento de perdas de carga, o envelhecimento do leito, o seu quebramento e a formação de zonas não homogêneas, estes materiais são geralmente misturados a materiais inertes, como esferas de poliestireno, partículas de lava, bolinhas de vidro, argila porosa e materiais cerâmicos (CONVERTI et al., 2001).

$\mathrm{Na}$ presença de concentrações elevadas de poluentes, o volume e a espessura do biofilme formado em torno das partículas do material filtrante, aumentam, reduzindo a porosidade do meio, podendo acarretar na colmatação do leito (WANNER, et al. 1995). Nessa situação a operação do biofiltro necessita uma substituição mais freqüente de material filtrante (JORIO \& HEITZ, 1999).

Outra importante característica do meio suporte, e que deve ser observada com grande interesse, é a capacidade de adsorção que alguns recheios apresentam.

As curvas de ruptura para adsorção consistem no método de mais amplo emprego para estudo de perfis de concentração no interior de equipamentos adsorvedores. Sua utilização em maior escala, quando comparado com outros métodos, se justifica pela facilidade de obtenção dos dados necessários para sua elaboração. A curva de ruptura em si consiste num gráfico de $\mathrm{C} / \mathrm{Co}$ em função do tempo, onde $\mathrm{C}$ é a concentração do adsorvato na corrente de saída do adsorvedor e Co é a concentração do adsorvato na corrente de entrada do adsorvedor.

Um exemplo típico de curva em um processo de adsorção é apresentado na Figura 4.

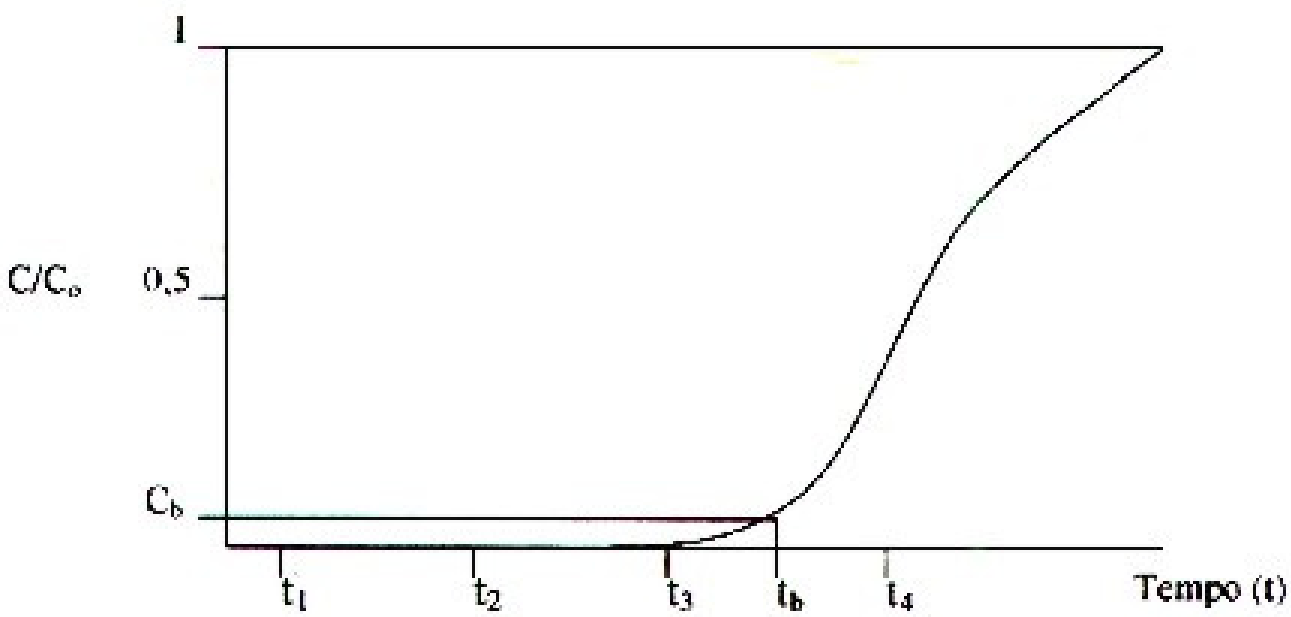

Figura 4. Curva de ruptura típica para adsorção em leito fixo. FONTE: McCABE et al. (1986). 
A partir do perfil apresentado na Figura 4, observa-se que a concentração de saída nos tempos $t_{1}$ e $t_{2}$ é praticamente zero, e que a medida que o tempo vai passando a concentração de saída tende a aumentar. O processo de adsorção é mantido até que se alcance a concentração desejada na saída $\left(C_{b}\right)$, que freqüentemente é definida entre $C / C_{o}=$ 0,05 e $\mathrm{C} / \mathrm{C}_{\mathrm{o}}=0,10$, e é chamada de ponto de ruptura. O tempo necessário para alcançar esta concentração $\left(\mathrm{C}_{\mathrm{b}}\right)$ é chamado de tempo de ruptura $\left(\mathrm{t}_{\mathrm{b}}\right)$. Caso o processo de adsorção seja mantido além do ponto de ruptura, a concentração do adsorvato na fase fluida efluente tende a aumentar até alcançar o valor da concentração do adsorvato na alimentação, provocando assim a saturação do leito.

As curvas de ruptura também permitem a avaliação da homogeneidade do recheio adsorvente, a Figura 5 apresenta as curvas de ruptura para a) recheio homogêneo, b) com canais preferenciais, c) com zonas de estagnação e d) com zonas mortas.

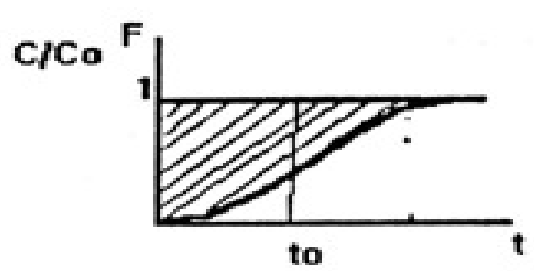

(a)

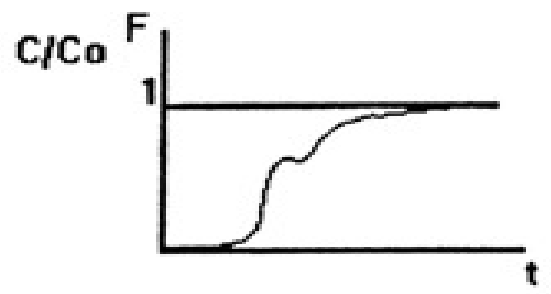

[c]

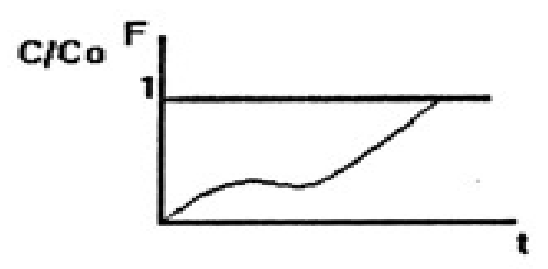

[b]

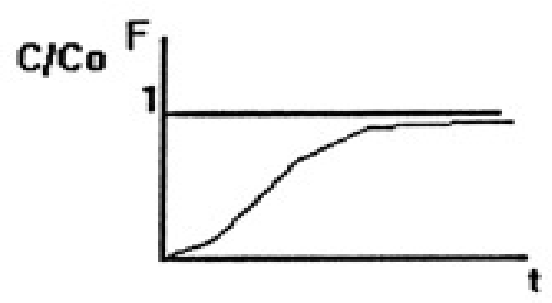

[d]

Figura 5. Curvas de ruptura para recheios com diferentes características: a) recheio homogêneo; b) recheio com canais preferenciais; c) recheio com zonas de estagnação e d) recheio com zonas mortas. FONTE: McCABE et al. (1986).

As curvas de ruptura apresentados por Moe e Irvine (2000a) na Figura 6 apesar de serem para tolueno mostram a baixa capacidade adsorvente da espuma de poliuretano. 


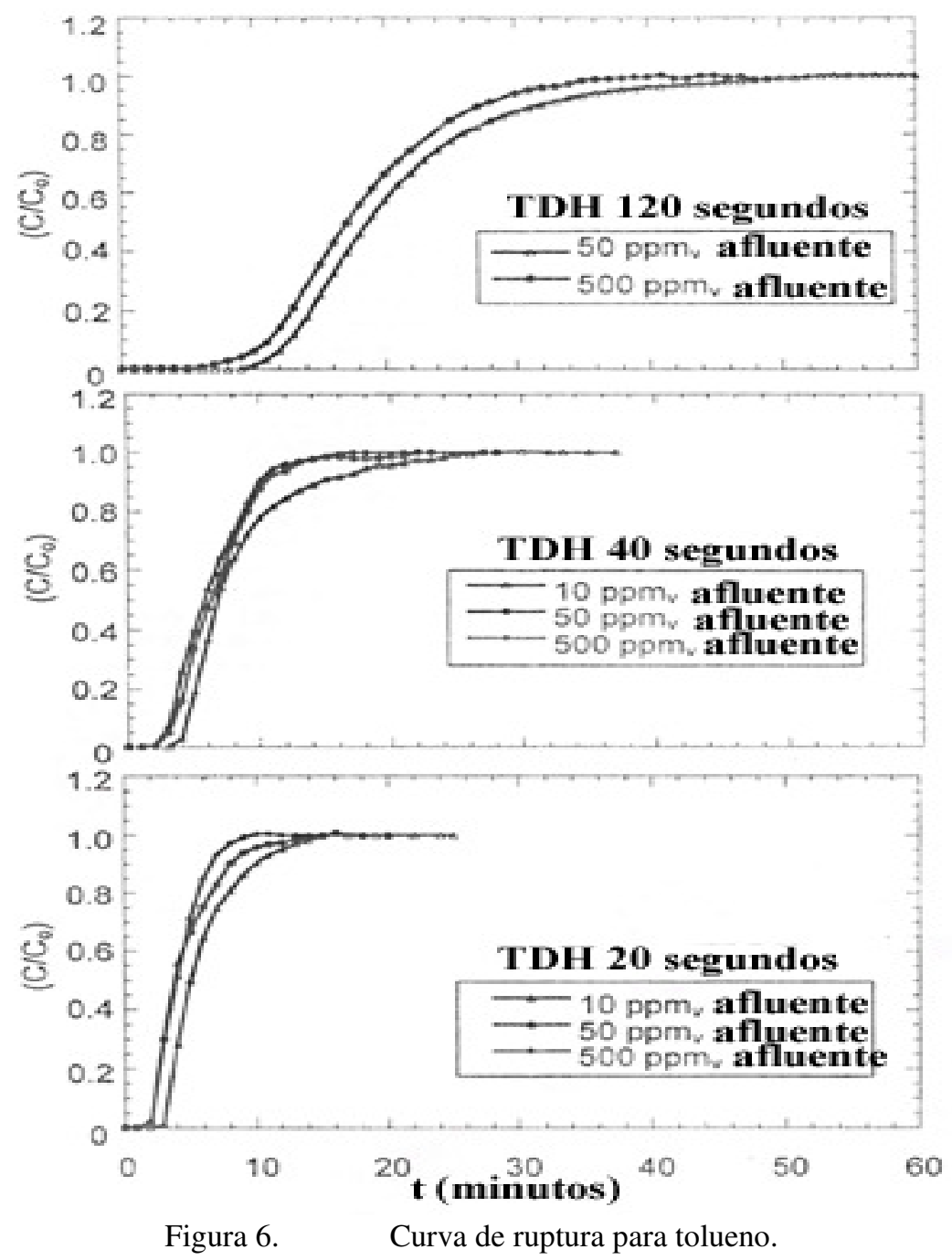

Fonte: Moe e Irvine (2000a)

Vários elementos naturais ou subprodutos de certas indústrias podem ser utilizados como leito filtrante. Entre eles, as fibras de coco, as cascas do cacau, os grãos de arroz, areia de algas marinhas, seixo e os materiais mais convencionais, tais como carvão, compostos, folhas, galhos secos e casca de madeira. Hodge e Devinny (1994); Webster et al. (1997) propuseram o uso de leitos filtrantes compostos de materiais sintéticos sob a forma de cacos de cerâmica, carvão ativado, vidro e argila. Esses materiais naturais ou sintéticos não apresentam todas as qualidades pesquisadas para constituir um leito filtrante ideal. Entretanto, cada um desses materiais corresponde a uma das características pesquisadas.

Atualmente para satisfazer o máximo de critérios, vários pesquisadores como Smet et al. 1996, Wu et al. 1999; Deshusses 1997, Chou \& Cheng 1997, industriais e vendedores de leitos filtrantes propõe misturas compostas de materiais com excelentes características 
biológicas (composto, carvão, etc.) e uma fração media de partículas de materiais inertes (JORIO \& HEITZ, 1999).

Esses materiais reforçam a estrutura do leito e aumentam sua permeabilidade, evitando também a formação de caminhos preferenciais e melhorando a distribuição do gás e dos nutrientes no biofiltro. O carvão ativado atenua os efeitos tóxicos da concentração dos poluentes, graças a sua excelente propriedade adsorvente. Os leitos assim compostos ocasionam uma baixa perda de carga e são mais duráveis, porém, mais custosos que os leitos convencionais (EDWARDS \& NIRMALAKHANDAN, 1996).

A espuma de poliuretano foi estudada por Moe e Irvine (2000 a e b), monitorando a produção até seu emprego em biofiltros. Os autores citaram que este meio suporte pode ser preparado com materiais hidrofílicos promovendo uma reumidificação mais eficiente no caso de problemas de secagem do leito. Moe e Irvine (2000a) fizeram uma caracterização do empacotamento da espuma de poliuretano e obtiveram uma porosidade do leito de 0,85 e perdas de carga menores que $0,2.10^{-2}$ mca por metro de recheio, correspondentes as encontradas por Rodrigues (2002a) e Maia (2003) que segundo estes os autores, também apresentou o melhor desempenho em biofiltros dentre os outros suportes testados (carvão ativado, solo, cilindros de poliestireno e contas de alginato de cálcio).

Como características principais, a espuma de poliuretano apresenta uma grande capacidade de retenção de umidade e uma baixa densidade, os poros da espuma de poliuretano possibilitam uma adesão de microrganismos.

\subsubsection{Teor de umidade no biofiltro}

O teor de umidade é o parâmetro mais crítico, por ser essencial à sobrevivência, à atividade dos microrganismos e por contribuir para a capacidade tamponante do biofiltro. A taxa de umidade do material suporte em um biofiltro varia de 40 a $60 \%$ em peso (JORIO \& HEITZ, 1999; CONVERTI et al., 2001).

A falta de umidade no material filtrante limita a transferência dos poluentes da fase gasosa para a fase líquida e sua difusão através do biofilme líquido, reduzindo a atividade dos microrganismos e diminuindo a eficiência do biofiltro. Uma umidade excessiva do leito filtrante também diminui a performance do biofiltro, nesse caso a porosidade do leito diminui reduzindo a superfície do biofilme disponível para transferência dos poluentes da 
fase gasosa. O acúmulo de água no leito pode acarretar sua compactação e a formação de zonas anaeróbias (JORIO \& HEITZ, 1999).

O consumo de água no biofiltro depende da temperatura, do calor liberado pela oxidação microbiana dos poluentes e da umidade relativa do gás. Por causa da evaporação, é preciso fornecer continuamente água ao sistema para garantir um grau de saturação da corrente gasosa maior que 95\%, necessário para manter as condições ideais para os microrganismos. Isso pode ser feito umidificando-se o fluxo gasoso contínuo através de um sistema a aspersão de água colocado antes da unidade de filtração, ou periodicamente, banhando-se o material filtrante por meio de aspersores superficiais, atomizadores, etc (CONVERTI et al., 2001).

\subsubsection{A importância do pH em biofiltros}

$\mathrm{O}$ efeito do $\mathrm{pH}$ sobre os sistemas de biofiltração é o resultado indireto da sua ação sobre a velocidade das reações enzimáticas, na biofiltração. Assim como na maioria dos processos aeróbios, a atividade é geralmente máxima dentro do intervalo de $\mathrm{pH}$ que vai de 5 a 9, com valores ótimos entre 6 e 8. Devido ao fato de que nos biofiltros a fase liquida é estacionária, podendo ocorrer fenômenos de acidificação do meio suporte, durante a biodegradação de poluentes sulfurados, nitrogenados e halogenados, o que leva a formação de produtos ácidos como ácido sulfúrico, nítrico e clorídrico como exemplificado na eq. 10 (CONVERTI et al., 2001).

$$
\mathrm{H}_{2} \mathrm{~S}+2 \mathrm{O}_{2} \stackrel{\text { Oxidação_Biológica }}{\longrightarrow} \mathrm{H}_{2} \mathrm{SO}_{4}
$$

Em meio líquido o $\mathrm{H}_{2} \mathrm{~S}$ se ioniza parcialmente, formando polissulfetos e com isso podendo também aumentar o $\mathrm{pH}$ do meio, de acordo com a eq. 11 fornecida por JONES (1973).

$$
\mathrm{H}_{2} \mathrm{~S} \leftrightarrow \mathrm{HS}^{-}+\mathrm{H}^{+} \leftrightarrow \mathrm{S}^{2-}+2 \mathrm{H}^{+}
$$

\subsubsection{A influência da temperatura nos biofiltros}

A temperatura também influencia o crescimento microbiano através dos seus efeitos sobre a atividade enzimática e os vários processos metabólicos. Os microrganismos aeróbios normalmente presentes nos biofiltros são mesófilos (temperaturas entre $20 \mathrm{e}$ 
$40^{\circ} \mathrm{C}$ ), com um valor ótimo de $35^{\circ} \mathrm{C}$ para os mais comuns. Apesar das velocidades de reação e difusão aumentarem com a temperatura, este efeito é contrabalançado pela diminuição de solubilidade dos compostos a serem removidos e de capacidade de adsorção física do material de enchimento (CONVERTI et al., 2001).

No momento da biofiltração, parte da energia liberada pelas reações de biodegradação dos poluentes é utilizada para síntese e crescimento de novas células. $\mathrm{O}$ aumento da temperatura entre a entrada e a saída do biofiltro é em geral da ordem de 2 a $4^{\circ} \mathrm{C}$, podendo atingir o máximo de $10{ }^{\circ} \mathrm{C}$, quando são tratadas correntes gasosas com altas concentrações de poluentes orgânicos (JORIO \& HEITZ, 1999).

\subsubsection{Tempo de residência e altura do leito dos biofiltros}

O tempo de permanência do ar deve ser maior que 15 ou 30 segundos para permitir a transferência do oxigênio e dos contaminantes para o biofilme ocorrendo assim à degradação biológica (LI et al., 1996; SORIAL et al., 1997; VAN LITH et al., 1997).

Em geral, a maioria dos biofiltros é operada com tempo de resistência em leito vazio, variando de 30 segundos a 2 minutos. A escolha do tempo de permanência do ar depende da natureza dos poluentes. A degradação de contaminantes pouco solúveis na água ou dificilmente biodegradáveis necessita de tempos de permanência mais elevados.

A escolha da altura do leito é determinante para o dimensionamento de um biofiltro; uma grande área resulta em dificuldades operacionais tais como a distribuição não uniforme dos gases sobre a seção do leito, reduzindo assim o tempo de contato entre os contaminantes e a flora microbiana. Por outro lado, uma altura muito elevada pode causar excessivas perdas de carga, permitindo o acréscimo da energia necessária para veicular o efluente poluído. Leitos muito altos ficam sempre expostos a problemas de compactação. Em geral, é aconselhado utilizar leitos de altura entre 0,50 e 2,00 m. A maioria dos biofiltros industriais tem altura próxima a 1,00 m (WANI et al., 1997).

\subsection{Resultados de pesquisas}

O Thiobacillus sp. foi amplamente utilizado em estudos de conversão do $\mathrm{H}_{2} \mathrm{~S}$ e outros compostos sulfurosos por processos biológicos (SUBLETTE \& SYLVESTER, 
1987; CHUNG et al., 1996a; CHA et al., 1999; OYARZÚN et al., 2003). Estas bactérias têm a habilidade de crescer sob várias condições de stress ambiental como déficit de oxigênio, condições ácidas, entre outras. Muitos Thiobacillus sp. (como Thiobacillus thiooxidans, Thiobacillus ferrooxidans) tem características acidofílicas e são capazes de se desenvolver em condições de pH baixo (1-6). Outros Thiobacillus sp. (como Thiobacillus thioparus, Thiobacillus denitrificans, Thiobacillus novellus) se desenvolvem em $\mathrm{pH}$ próximos a neutralidade (6-8)

Maka e Cork (1990) investigaram o efeito da quantidade e da intensidade de luz no metabolismo do $\mathrm{H}_{2} \mathrm{~S}$ em um reator fed-batch. A intensidade da luz foi variada, mantendose a área de exposição do reator constante a taxas de alimentação de $32 \mathrm{ou} 64 \mathrm{mg} \cdot \mathrm{S}^{2-} \cdot \mathrm{h}^{-1} . \mathrm{L}^{-}$ 1. Em uma alta intensidade luminosa o sulfeto foi removido e mais da metade foi convertido a sulfato. A baixas intensidades, o sulfeto não foi completamente oxidado e esse foi acumulado no reator.

Cho et al. (1992a) trabalharam com um biofiltro cilíndrico em escala piloto de 500 $\mathrm{mm}$ de diâmetro por $850 \mathrm{~mm}$ de altura feito em aço, com um leito fibroso e inoculado com uma cultura pura de Thiobacillus thioparus DW44 previamente adaptada. O biofiltro foi instalado em uma estação de tratamento de resíduo sólido. Uma remoção quase que completa (maior que 99\%) foi observada imediatamente após a partida e esta se manteve constante durante todo o período do experimento para concentrações de entrada que variavam de 25 a $45 \mathrm{ppm}$.

Chung et al. (1996b) trabalharam com um sistema de biofiltração inoculado com Pseudomonas putida CH11 imobilizada em alginato de cálcio que, de acordo com os autores, além de diminuir a altura do leito, aumentou a eficiência de remoção de $\mathrm{H}_{2} \mathrm{~S}$. Os pesquisadores analisaram o comportamento do sistema em concentrações entre 10 e 60 ppm e vazões entre 36 e 72 L.h $^{-1}$ e obtiveram, em todas as condições de operação, um bom desempenho, com uma eficiência superior a $95 \%$.

Chung et al. (1997) utilizaram Thiobacillus novellus em um biofiltro para a oxidação do $\mathrm{H}_{2} \mathrm{~S}$, sob condições mixotróficas. A eficiência de remoção atingida foi de $99,6 \%$ e os produtos formados foram sulfato $(83,6 \%)$ e sulfeto $(12,6 \%)$. Uma pequena conversão do sulfeto para enxofre elementar foi detectada. 
O trabalho de Wani et al. (1999) foi direcionado à degradação de gás sulfídrico juntamente com compostos reduzidos de enxofre como dimetil sulfeto (DMS) e dimetil disulfeto (DMDS), para verificar possíveis interferências destes compostos na remoção de $\mathrm{H}_{2} \mathrm{~S}$. Para o desenvolvimento da pesquisa, os autores utilizaram três colunas, empacotadas com composto, resíduo de jardinagem e com a mistura de ambos, respectivamente. Em todos os biofiltros foi adicionado perlita (uma parte para quatro de meio), para aumentar a porosidade do leito, e dolomita. $\mathrm{O}$ meio foi inoculado com lodo ativado e deu-se início à adaptação do sistema, que durou duas semanas, aumentando-se gradativamente a concentração de 10 a 500 ppm. Após seis meses de operação, os autores observaram uma queda do pH, de cerca de 7,0 para 2,0, atribuída à formação de metabólitos ácidos. Os biofiltros alcançaram $100 \%$ de remoção de $\mathrm{H}_{2} \mathrm{~S}$, para uma concentração de entrada de 250 ppm, sendo que, para valores superiores a este a eficiência foi de 90\%. Diante dos resultados os autores concluíram que a presença de DMS e DMDS não interferiu na remoção de $\mathrm{H}_{2} \mathrm{~S}$.

A comparação entre as eficiências de remoção do $\mathrm{H}_{2} \mathrm{~S}$ inorgânico e compostos orgânicos sulfurados (metil mercaptanas, dimetil sulfeto e dimetil disulfeto) pela imobilização de Thiobacillus novellus é apresentada no estudo de Cha et al., (1999). Eles observaram que o Thiobacillus novellus conseguiu degradar $\mathrm{H}_{2} \mathrm{~S}$ e metil mercaptanas com $100 \%$ de eficiência, dimetil dissulfeto com $87 \%$ e dimetil sulfeto com $73 \%$. O produto final do processo metabólico encontrado foi o sulfato.

Chung et al. (2001) estudaram a degradação de $\mathrm{H}_{2} \mathrm{~S}$ juntamente com $\mathrm{NH}_{3}$, utilizando as bactérias heterotróficas Pseudomonas putida CH11 e Arthrobacter oxydans CH8 imobilizadas em alginato de cálcio. Os autores utilizaram várias taxas de a alimentação (1:1, - igual a 60:60 ppm - 1:2 e 2:1), sendo que para uma alimentação de $\mathrm{H}_{2} \mathrm{~S}$ e $\mathrm{NH}_{3}$ numa proporção de 1:2, a maior concentração de $\mathrm{NH} 3$ provocou uma queda da remoção de $\mathrm{H}_{2} \mathrm{~S}$ (90\%), atribuída a uma queda do $\mathrm{pH}$ para 5,8. Esta acidificação resultou em queda da atividade da Pseudomonas putida, diminuindo, assim, a eliminação de $\mathrm{H}_{2} \mathrm{~S}$. Já a alimentação com concentração maior de $\mathrm{H}_{2} \mathrm{~S}$ resultou em uma inibição do metabolismo da Pseudomonas putida (95\% para 92\% de eficiência) e reduziu a remoção de amônia (de 98 para 94\%).

Elias et al. (2002) utilizaram um meio suporte constituído de estrume de porco e serragem para fins de biofiltração. Os autores conseguiram uma taxa de carregamento de 
$45 \mathrm{~g} / \mathrm{m}^{3}$.h. Nenhum nutriente foi adicionado ao sistema e a porosidade do leito caiu de 23,1 para $12,9 \%$. Contudo, esta mudança na porosidade, não afetou a eficiência de remoção significativamente e isso possibilitou que o biofiltro pudesse ser facilmente limpo por uma descarga de água através da entrada. O principal produto formado no processo foi enxofre elementar ( $82 \%$ da acumulação total de enxofre), acompanhado pela formação de sulfatos e tiosulfatos $(18 \%)$.

Kim et al. (2002) investigaram a remoção simultânea de $\mathrm{H}_{2} \mathrm{~S}$ e $\mathrm{NH}_{3}$ utilizando dois biofiltros, um empacotado com lascar de madeira e o outro com carvão ativado. A mistura de lodo ativado e Thiobacillus thioparus foi pulverizada no material empacotado e o percolado foi recirculado para aumentar a inoculação dos microrganismos. Inicialmente os dois biofiltros apresentaram altas eficiências $(99,9 \%)$. Contudo, devido ao acumulo de enxofre elementar e sulfato de amônio no material suporte, a eficiência de remoção com o passar do tempo decaiu para 75 e $30 \%$ respectivamente para o $\mathrm{H}_{2} \mathrm{~S}$ e a $\mathrm{NH}_{3}$.

Hartikainen et al. (2002) testaram a trufa como material suporte e observaram que a remoção do $\mathrm{H}_{2} \mathrm{~S}$ era possível sem a necessidade de inoculação do biofiltro com microrganismos. A trufa naturalmente ácida ( $\mathrm{pH} 4)$ foi testada com e sem a correção do pH. O biofiltro com correção do $\mathrm{pH}$ removeu $95 \%$ do $\mathrm{H}_{2} \mathrm{~S}$ depois de um dia de operação enquanto que o biofiltro sem a correção do pH alcançou a mesma eficiência após 1 mês.

Kleerebezen e Mendez (2002) propuseram a simultânea degradação do $\mathrm{H}_{2} \mathrm{~S}$ e $\mathrm{NH}_{3}$ utilizando o Thiobacillus denitrificans e bactérias nitrificantes. O Thiobacillus denitrificans é capaz de degradar o $\mathrm{H}_{2} \mathrm{~S}$ em condições tanto anaeróbias quanto aeróbias, utilizando o oxigênio ou o nitrato como aceptor de elétrons. $\mathrm{O}$ nitrato $\left(\mathrm{NO}_{3}\right)$ pode ser obtido a partir da nitrificação da amônia pelas bactérias nitrificantes. O Thiobacillus denitrificans oxida simultaneamente $\mathrm{o} \mathrm{H}_{2} \mathrm{~S}$ para enxofre elementar ou sulfato e reduz o nitrato a nitrogênio gasoso.

Rodrigues (2002a) utilizando uma coluna em acrílico de $5 \mathrm{~cm}$ de diâmetro interno e $25 \mathrm{~cm}$ de altura testou como meio suporte a espuma de poliuretano e solo. Como inóculo foram testadas as culturas puras de Thiobacillus thioparus e Pseudomonas Putida tratando o $\mathrm{H}_{2} \mathrm{~S}$ em concentrações que variaram de 15 a $245 \mathrm{ppm}$, em que, devido a dificuldades operacionais na coluna de solo e na adaptação da cultura de Pseudomonas Putida, o estudo foi realizado apenas para a cultura de Thiobacillus thioparus e a espuma de poliuretano, 
em que para essa faixa de concentração as eficiências se mantiveram sempre acima dos $90 \%$.

Segundo Busca e Pistarino (2003), os dados experimentais mostram que o enxofre mineralizado em biofiltros aumenta principalmente os íons sulfato os quais se mantêm no biofiltro, sendo que apenas quando as concentrações forem relativamente altas será encontrada uma significante acidificação do reator.

Malhautier et al. (2003) estudaram a degradação conjunta de $\mathrm{H}_{2} \mathrm{~S}$ e $\mathrm{NH}_{3}$ utilizando dois biofiltros em escala de bancada, empacotados com lodo granulado. Uma unidade foi alimentada principalmente com $\mathrm{H}_{2} \mathrm{~S}$ e a outra com $\mathrm{NH}_{3}$. Para o $\mathrm{H}_{2} \mathrm{~S}$ a eficiência obtida foi de $100 \%$ e para a $\mathrm{NH}_{3}$ a eficiência de remoção obtida foi de $80 \%$. Contudo os autores concluíram que a oxidação de altos níveis de $\mathrm{H}_{2} \mathrm{~S}$ pode ter um efeito negativo no crescimento e na atividade das bactérias nitrificantes.

Morgan-sagastume et al. (2003) investigaram mudanças nas propriedades físicas de um biofiltro em escala de bancada, preenchido com um meio constituído de compostagem de alimentos, folhas, restos de jardinagem e esterco de cavalo. A eficiência de remoção decaiu de 100 para 90\% após 206 dias de operação. Eles então concluíram que a variação no conteúdo da mistura e a área especifica podem explicar o decréscimo na eficiência de remoção ao longo do tempo. Eles também mencionam que a acumulação do $\mathrm{SO}_{4}{ }^{-2}$ reduziu o pH do meio de 7,5 para 4,4. Após revolverem a material suporte, a eficiência de remoção retornou para próxima de $100 \%$.

Maia (2003) estudou o tratamento biológico do $\mathrm{H}_{2} \mathrm{~S}$, utilizando uma coluna de acrílico de $5,0 \mathrm{~cm}$ de diâmetro interno e dois módulos de $12,5 \mathrm{~cm}$ cada, totalizando $25 \mathrm{~cm}$ de altura. A bactéria utilizada foi o Thiobacillus thioparus e os suportes testados no trabalho foram espuma de poliuretano e contas de alginato/quitosana, uma vez que o biofiltro necessita de adição freqüente de umidade. Logo após um período de adaptação a eficiência de remoção atingiu patamares de $98 \%$ para a coluna com alginato/quitosana e 90\% para a coluna com espuma de poliuretano.

Clark et al. (2004) operaram um biofiltro em escala piloto para reduzir o odor dos gases de uma estação de tratamento de esterco de suínos. O biofiltro foi empacotado com partículas de poliestireno e turfa na proporção de 3:1 em volume. O volume empacotado 


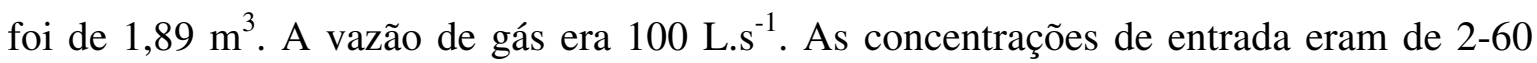
ppm de $\mathrm{H}_{2} \mathrm{~S}$ e 2-30 ppm de $\mathrm{NH}_{3}$. A adição de nutrientes não demonstrou ser um aspecto importante no desempenho do sistema. A remoção média dos odores foi de aproximadamente $38 \%$ sem adição de nutrientes e $45 \%$ quando os nutrientes foram adicionados. O aumento da temperatura teve um efeito favorável somente durante a fase de adaptação.

Tacla (2004) trabalhou com nove biofiltros, testando três tipos de suporte diferentes (turfa, bagaço de cana e casca de arvore do tipo Pinus). Os biofiltros foram inoculados sendo dois com o suporte mais o lodo de uma indústria de celulose e papel e um com o suporte mais água, na fase final de operação onde a concentração média de sulfeto foi de $305 \mathrm{ppm}$. Os biofiltros com bagaço de cana e lodo apresentaram uma eficiência média de $87,35 \%$ e 55,73\%, para o bagaço de cana e água a eficiência média obtida foi de 51,26\%. Nos biofiltros com casca de pinus e lodo, as eficiências médias foram de 92,73\% e $94,63 \%$, para a casca de pinus e água a eficiência média foi de 94,98\%. Nos biofiltros com turfa e lodo as eficiências médias foram de $85,86 \%$ e $85,09 \%$, no biofiltro com turfa e águas a eficiência média foi de 93,50\%.

A Tabela 7 mostra um resumo dos resultados das pesquisas já realizadas para a remoção de $\mathrm{H}_{2} \mathrm{~S}$ utilizando-se biofiltros. 
TABELA 7 - Pesquisas realizadas na remoção de Sulfeto de Hidrogênio utilizando Biofiltros.

\begin{tabular}{|c|c|c|c|c|c|c|c|c|c|}
\hline Escala & Tipo de Leito & $\begin{array}{l}\text { Volume do } \\
\text { Leito }\end{array}$ & $\begin{array}{l}\text { Poluentes tratados e concentrações de } \\
\text { entrada }\end{array}$ & $\begin{array}{l}\text { Vazões e } \\
\text { tempos de } \\
\text { residência }\end{array}$ & $\begin{array}{l}\text { Tempo de } \\
\text { Operação }\end{array}$ & Microrganismo & $\begin{array}{l}\text { Eficiência } \\
\text { de remoção }\end{array}$ & Inoculação & Autor \\
\hline Laboratório & $\begin{array}{l}\text { Células } \\
\text { imobilizadas } \\
\text { Alginato de Cálcio }\end{array}$ & $0,7 \mathrm{~L}$ & Corrente de $\mathrm{Ar}$ com $\mathrm{H}_{2} \mathrm{~S}$ (5-100ppm) & $18-150 \mathrm{~L} / \mathrm{h}$ & 87 dias & T. thioparus & $\begin{array}{l}85-99 \% \\
\left(\mathrm{H}_{2} \mathrm{~S}\right)\end{array}$ & $\begin{array}{l}\text { Imobilização em Alginato } \\
\text { de Cálcio }\end{array}$ & CHUNG et al. (1996a) \\
\hline Laboratório & $\begin{array}{l}\text { Resíduo de } \\
\text { jardinagem }\end{array}$ & $18 \mathrm{~L}$ & Corrente de ar com $\mathrm{H}_{2} \mathrm{~S}$ (10-450ppm). & $\begin{array}{l}1,7 \mathrm{~m}^{3} / \mathrm{h} \\
38 \mathrm{~s}\end{array}$ & 30 dias & Cultura mista & $\begin{array}{l}90-100 \% \\
\left(\mathrm{H}_{2} \mathrm{~S}\right)\end{array}$ & Lodo Ativado & WANI et al. (1999) \\
\hline Laboratório & $\begin{array}{l}\text { Células } \\
\text { imobilizadas } \\
\text { Alginato de Cálcio }\end{array}$ & $0,7 \mathrm{~L}$ & $\begin{array}{l}\text { Corrente de ar com } \mathrm{H}_{2} \mathrm{~S}(60-120 \mathrm{ppm}) \text {, } \\
\mathrm{NH}_{3}(60-120 \mathrm{ppm})\end{array}$ & $\begin{array}{l}36 \mathrm{~L} / \mathrm{h} \\
72 \mathrm{~s}\end{array}$ & 30 dias & $\begin{array}{l}\text { Pseudomonas putida, } \\
\text { Arthrobacter oxydans }\end{array}$ & $\begin{array}{l}>90 \%\left(\mathrm{H}_{2} \mathrm{~S}\right) \\
\mathrm{S}_{\left(\mathrm{NH}_{3}\right)}\end{array}$ & $\begin{array}{l}\text { Imobilização de } \\
\text { Pseudomonas putida e } \\
\text { Arthrobacter oxydans em } \\
\text { alginato de cálcio }\end{array}$ & CHUNG et al. (2001) \\
\hline Laboratório & $\begin{array}{l}\text { Estrume de porco } \\
+ \text { serragem }\end{array}$ & $5,9 \mathrm{~L}$ & $\begin{array}{l}\text { Corrente de ar com } \mathrm{H}_{2} \mathrm{~S}(10-45 \\
\left.\mathrm{g} / \mathrm{m}^{3} \cdot \mathrm{h}\right)\end{array}$ & $13,5-27 \mathrm{~s}$ & 2500 horas & Cultura Mista & $>90 \%\left(\mathrm{H}_{2} \mathrm{~S}\right)$ & Não Houve & ELIAS et al. (2002) \\
\hline Real & $\begin{array}{l}\text { Espuma de } \\
\text { Poliuretano }\end{array}$ & $\begin{array}{l}500 \mathrm{~m}^{3}(6 \\
\text { unidades })\end{array}$ & $\begin{array}{l}\text { Efluente de Indústria de tabaco com } \\
\mathrm{H}_{2} \mathrm{~S} \text { (800-1200ppm) }\end{array}$ & $11 \mathrm{~s}$ & 42 dias & - & $>90 \%\left(\mathrm{H}_{2} \mathrm{~S}\right)$ & - & $\begin{array}{l}\text { COX \& DESHUSSES } \\
(2002)\end{array}$ \\
\hline Laboratório & $\begin{array}{l}\text { Lascas de } \\
\text { Madeira, carvão } \\
\text { ativado granulado }\end{array}$ & $1 \mathrm{~L}$ & $\begin{array}{l}\text { Corrente de ar com } \mathrm{H}_{2} \mathrm{~S} \text { (30-450ppm), } \\
\mathrm{NH}_{3}(35-300 \mathrm{ppm})\end{array}$ & $\begin{array}{l}60-180 \mathrm{~L} / \mathrm{h} \\
20-60 \mathrm{~s}\end{array}$ & 230 dias & T. thioparus & $\begin{array}{l}75-99 \% \\
\left(\mathrm{H}_{2} \mathrm{~S}\right) \\
30-92 \% \\
\left(\mathrm{NH}_{3}\right)\end{array}$ & $\begin{array}{l}\text { Lodo ativado }+ \\
\text { cultura de } T . \text { thioparus }\end{array}$ & KIM et al. (2002) \\
\hline Laboratório & $\begin{array}{l}\text { Partículas de } \\
\text { poliuretano }\end{array}$ & $1 \mathrm{~L}$ & $\begin{array}{l}\text { Efluente de um reator lift tratando } \\
\text { uma mistura Sulfeto/nitrato }\end{array}$ & - & 55 dias & T. denitrificans & $80 \%(\mathrm{~S})$ & - & $\begin{array}{l}\text { KLEEREBEZEM \& } \\
\text { MENDEZ (2002) }\end{array}$ \\
\hline Real & Lascas de madeira & $\begin{array}{l}\text { Leito } \\
\text { aberto }\end{array}$ & $\begin{array}{l}\text { Efluente gasoso com } \mathrm{H}_{2} \mathrm{~S} \\
\left(1,07 \mathrm{mg} / \mathrm{m}^{3}\right), \mathrm{NH}_{3}\left(5,2 \mathrm{mg} / \mathrm{m}^{3}\right) \text {, } \\
\text { methanethol }\left(0,66 \mathrm{mg} / \mathrm{m}^{3}\right), \text { etilamina } \\
\left(1,2 \mathrm{mg} / \mathrm{m}^{3}\right), \text { DMS }\left(775,25 \mathrm{mg} / \mathrm{m}^{3}\right)\end{array}$ & $\begin{array}{l}25.485 \mathrm{~m}^{3} / \mathrm{h} \\
30 \mathrm{~s}\end{array}$ & Não cita & Cultura mista & $\begin{array}{l}>96 \% \\
\text { (Todos) }\end{array}$ & Não Houve & $\begin{array}{l}\text { SHAREEFDEEN et al. } \\
\text { (2002) }\end{array}$ \\
\hline Laboratório & Lodo Granulado & $10 \mathrm{~L}$ & $\begin{array}{l}\text { Corrente de ar com } \mathrm{H}_{2} \mathrm{~S}(170- \\
\left.680 \mathrm{~g} / \mathrm{m}^{3} \cdot \mathrm{d}\right), \mathrm{NH}_{3}\left(340 \mathrm{~g} / \mathrm{m}^{3} \cdot \mathrm{d}\right)\end{array}$ & - & 21 semanas & $\begin{array}{l}\text { Bactéria nitrificante, } \\
\text { sbactéria oxidadora de } \\
\text { sulfeto }\end{array}$ & $\begin{array}{l}100 \%\left(\mathrm{H}_{2} \mathrm{~S}\right) \\
80 \%\left(\mathrm{NH}_{3}\right)\end{array}$ & Lodo Adaptado & $\begin{array}{l}\text { MALHAUTIER et al. } \\
\text { (2003) }\end{array}$ \\
\hline Laboratório & $\begin{array}{l}\text { Composto } \\
\text { Maturado }\end{array}$ & $8 \mathrm{~L}$ & Corrente de ar com $\mathrm{H}_{2} \mathrm{~S}$ (50ppm) & $10 \mathrm{~L} / \mathrm{min}$ & 206 dias & Cultura mista & $\begin{array}{l}90-100 \% \\
\left(\mathrm{H}_{2} \mathrm{~S}\right)\end{array}$ & Não Houve & $\begin{array}{l}\text { MORGAN- } \\
\text { SAGASTUME et al. } \\
(2003)\end{array}$ \\
\hline Laboratório & Turfa & $1 \mathrm{~L}$ & $\begin{array}{l}\text { Corrente de ar com } \mathrm{H}_{2} \mathrm{~S}(355- \\
1400 \mathrm{ppm})\end{array}$ & $30 \mathrm{~L} / \mathrm{h}$ & Não cita & T. thioparus & $\begin{array}{l}65-100 \% \\
\left(\mathrm{H}_{2} \mathrm{~S}\right)\end{array}$ & T. thioparus & $\begin{array}{l}\text { OYARZÚN et al. } \\
(2003)\end{array}$ \\
\hline Real & - & - & Biogás com $\mathrm{H}_{2} \mathrm{~S}$ (5000ppm) & $10-350 \mathrm{~m}^{3} / \mathrm{h}$ & Não cita & Thiobacillus sp. & $>90 \%\left(\mathrm{H}_{2} \mathrm{~S}\right)$ & Lodo Ativado & $\begin{array}{l}\text { SCHIEDER et al. } \\
(2003)\end{array}$ \\
\hline
\end{tabular}

FONTE: Adaptado de SYED et al. (2006). *MM = metil mercaptana; DMS = dimetil sulfeto; DMDS = dimetil disulfeto 


\section{MATERIAL E MÉTODO}

\subsection{Inóculo e Meio de Cultura}

O inóculo utilizado no experimento foi o lodo de uma unidade de lodos ativados que funciona como pós-tratamento de um reator UASB tratando esgotos domésticos, proveniente da Estação de Tratamento de Esgoto do Piracicamirim (ETE-Piracicamirim) da cidade de Piracicaba/SP.

O meio de cultivo utilizado foi o meio nutricional ATCC290-S6 para Thiobacillus sp. Esse meio é composto por sais minerais que suprem as necessidades nutricionais das bactérias, sendo sua composição descrita na Tabela 8 .

\begin{tabular}{cc}
\multicolumn{2}{c}{ TABELA 8 - Meio ATCC290-S6 } \\
\hline Reagente & Massa (g/L) \\
\hline $\mathrm{MnSO}_{4}$ & 0,02 \\
$\mathrm{KH}_{2} \mathrm{PO}_{4}$ & 1,20 \\
$\mathrm{MgSO}_{4} \cdot 7 \mathrm{H}_{2} \mathrm{O}$ & 1,80 \\
$\left(\mathrm{NH}_{4}\right)_{2} \mathrm{SO}_{4}$ & 0,10 \\
$\mathrm{CaCl}_{2}$ & 0,10 \\
$\mathrm{FeCl}_{3}$ & 0,02 \\
$\mathrm{Na}_{2} \mathrm{~S}_{2} \mathrm{O}_{3}$ & 10,0 \\
\hline
\end{tabular}

\subsection{Adaptação do Inóculo}

A adaptação dos microrganismos foi realizada em barrilete de $25 \mathrm{~L}$ com solução nutriente ATCC290-S6 e lodo na proporção de 50\% (v/v), sendo 10 L de lodo e $10 \mathrm{~L}$ de meio nutriente. Durante sete dias, o barrilete foi mantido sob aeração sendo adicionado no inóculo, a cada a cada 48 horas, solução nutriente (supondo-se que todo o nutriente já houvesse sido consumido nesse período).

Decorrido o período de adaptação dos microrganismos ao meio nutriente e seleção dos mesmos em função da solução nutriente, continuou-se por mais sete dias a aeração do inóculo juntamente com a adição da solução nutriente. Nesse período, foi retirado da 
solução o tiossulfato $\left(\mathrm{Na}_{2} \mathrm{~S}_{2} \mathrm{O}_{3}\right)$, sendo este substituído pelo $\mathrm{H}_{2} \mathrm{~S}$ na forma gasosa fornecido juntamente com a aeração, para que nesse período os microrganismos se adaptassem à nova fonte de sulfeto.

Terminado os períodos de adaptação, foi realizada a inoculação dos microrganismos na espuma de poliuretano segundo a metodologia que será apresentada posteriormente, no item 4.4 - Empacotamento do recheio.

\subsection{Espuma de poliuretano como meio suporte}

O meio suporte utilizado no experimento foi a espuma de poliuretano, com massa específica ( $\rho)$ de $0,023 \mathrm{~g} . \mathrm{cm}^{-3}$, como citado por Maia (2003).

A espuma de poliuretano foi cortada em cubos de aproximadamente $5 \mathrm{~mm}$ de aresta para manter a relação de 1:10 com o diâmetro do reator, para se evitar ao máximo o efeito de parede no biofiltro (ZOTIN, 1985).

Uma foto da espuma de poliuretano cortada e sem inóculo é mostrada na Figura 7.

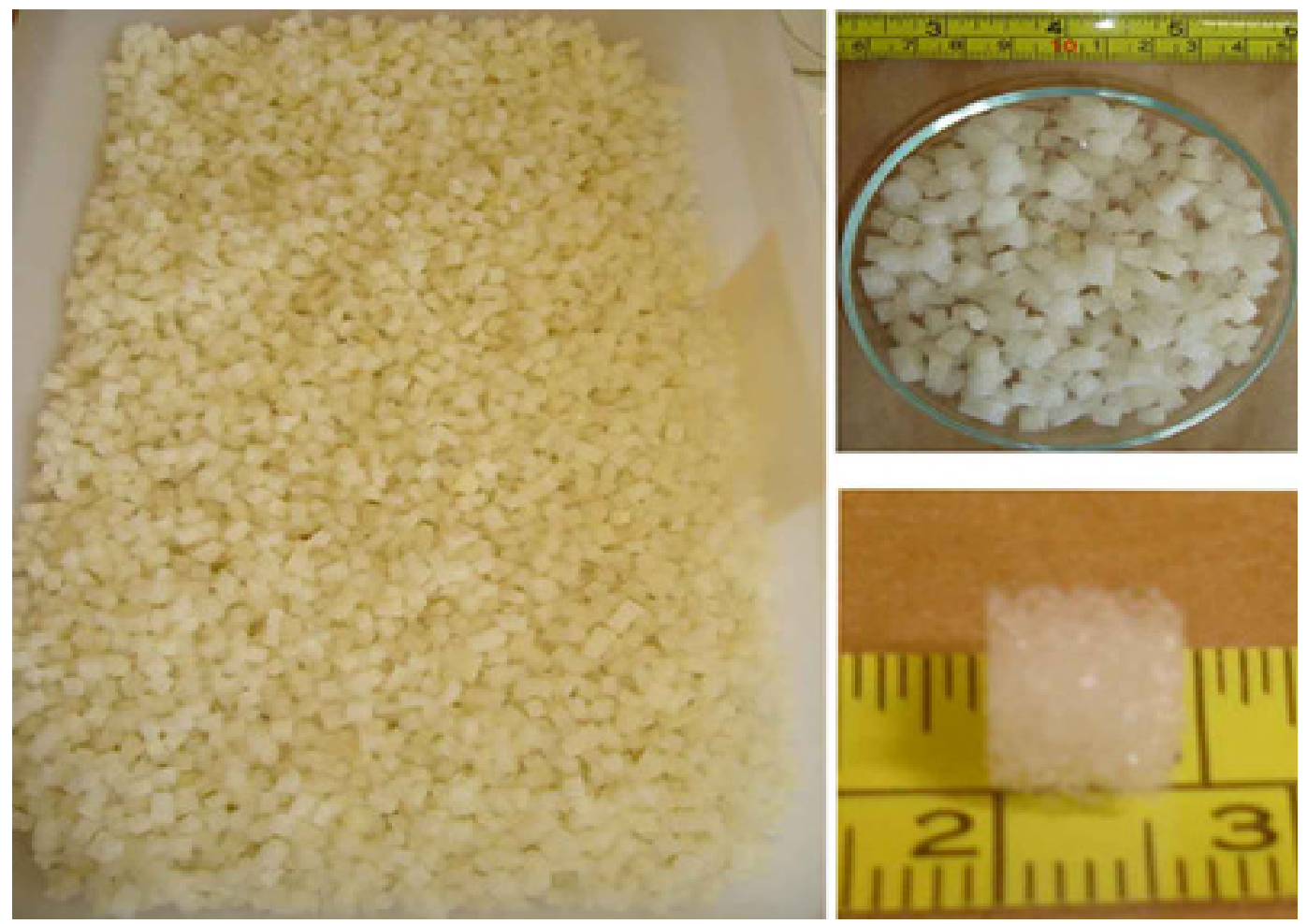

Figura 7. Espuma de poliuretano cortadas em cubos de $5 \mathrm{~mm}$. 
Para se exemplificar a grande porosidade da espuma é apresentada na Figura 8 uma foto de microscopia eletrônica de varredura com ampliação de 20 vezes com o detalhamento dos poros da espuma.

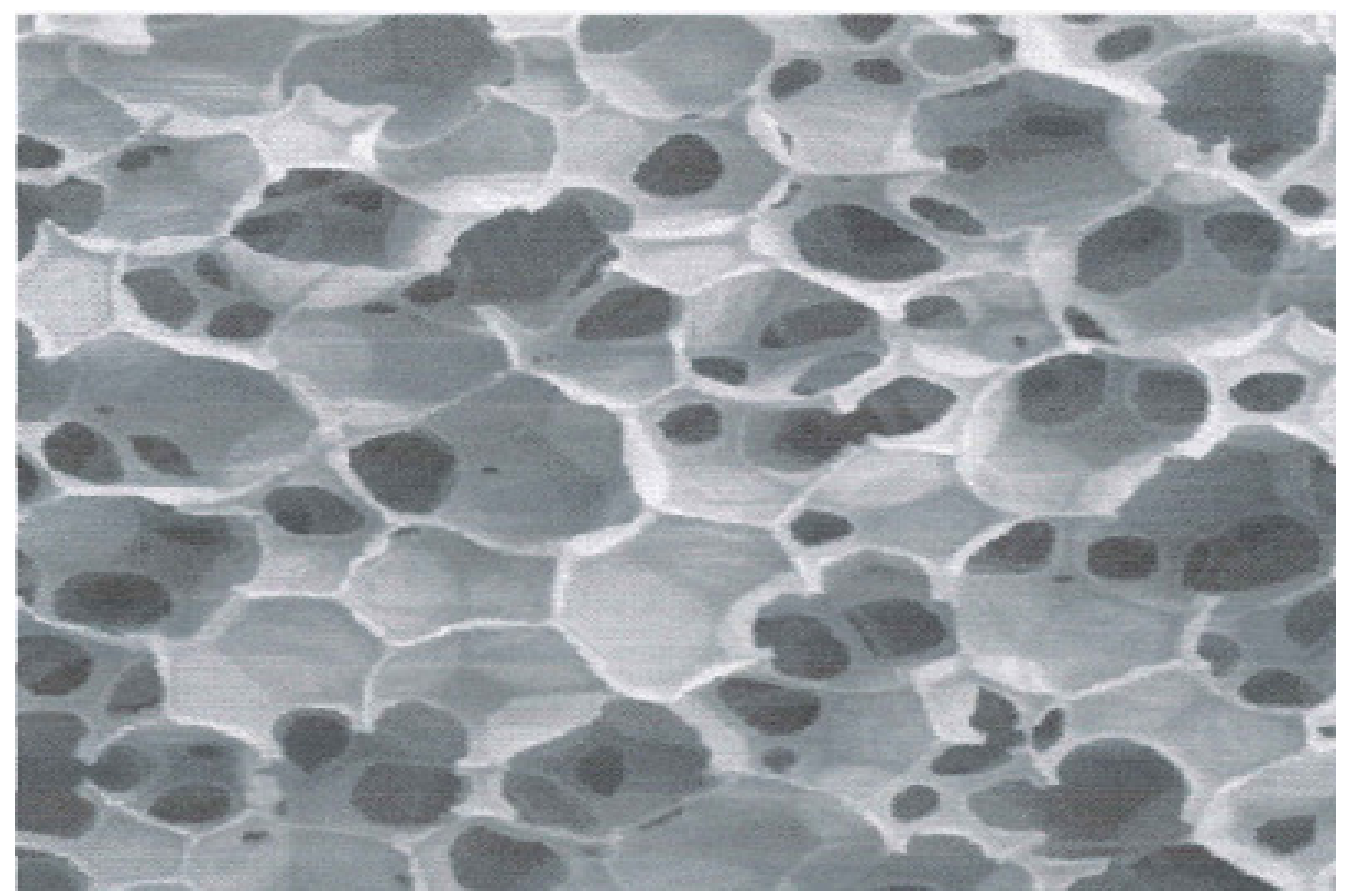

Figura 8. $\quad$ Espuma de poliuretano com aumento de 20 vezes.

A porosidade da espuma foi calculada de dois modos. O método 1 foi realizado pesando-se a mesma massa de espuma seca utilizada no experimento encharcando-se essa massa e pesando-a novamente. Com esses valores e adotando-se a massa específica da água a $25^{\circ} \mathrm{C}$ como sendo $0,997 \mathrm{~g} . \mathrm{cm}^{-3}$ (FOX \& MACDONALD, 2001) e com o auxílio da eq. 12, obteve-se o volume de água presente no leito de espuma que é equivalente ao volume de vazios.

$$
\rho=\frac{\left(m_{t}-m_{e}\right)}{V}
$$

Onde:

$\rho=$ Massa específica da água a $25^{\circ} \mathrm{C}\left[\mathrm{g} \cdot \mathrm{cm}^{-3}\right]$;

$\mathrm{m}_{\mathrm{t}}=$ Massa total do leito (espuma + água) [g];

$\mathrm{m}_{\mathrm{e}}=$ Massa de espuma seca $[\mathrm{g}]$;

$\mathrm{V}=$ Volume de água no leito $\left[\mathrm{cm}^{3}\right]$. 
Calculado o volume de água no leito (equivalente ao volume de vazios) calculou-se o volume do leito e utilizando-se a eq. 13 obteve-se a porosidade da espuma.

$$
\varepsilon_{\text {esp }}=\frac{\mathrm{V}_{\mathrm{v}}}{\mathrm{V}_{\mathrm{t}}}
$$

Onde:

$\varepsilon_{\text {esp }}=$ Porosidade da espuma;

$\mathrm{V}_{\mathrm{v}}=$ Volume de vazios $\left[\mathrm{cm}^{3}\right]$

$\mathrm{V}_{\mathrm{t}}=$ Volume total do leito $\left[\mathrm{cm}^{3}\right]$

A porosidade da espuma também foi calculada através do método 2 utilizando-se a eq. 14 e a densidade específica da espuma como sendo $0,023 \mathrm{~g} \cdot \mathrm{cm}^{-3}$ (MAIA, 2003).

$\rho_{\text {esp }}=\frac{m_{\text {esp }}}{V_{\text {esp }}}$

Onde:

$$
\begin{aligned}
& \rho_{\text {espuma }}=\text { Densidade específica da espuma }\left[\mathrm{g} \cdot \mathrm{cm}^{-3}\right] \\
& \mathrm{m}_{\text {espuma }}=\text { Massa da espuma }\left[\mathrm{cm}^{3}\right] \\
& V_{\text {espuma }}=\text { Volume da espuma }\left[\mathrm{cm}^{3}\right]
\end{aligned}
$$

\subsection{Empacotamento do recheio}

A espuma foi saturada com o lodo tomando-se cuidado de preenche-la por completo com o inóculo, e depois adicionada no interior do biofiltro em pequenas porções com o auxílio de uma escumadeira. Com o intuito de não remover o inóculo presente nos poros da espuma, o empacotamento foi concluído dando-se leves batidas na parede do reator com o auxílio de um martelo de borracha, para que a espuma melhor se acomodasse. A distribuição da espuma dentro do reator seguiu apenas orientação visual para tentar 
proporcionar o melhor acomodamento possível do recheio a fim de se evitar a formação de caminhos preferenciais ou zonas com diferentes compactações.

\subsection{Sistema de biofiltração}

A Figura 9 ilustra esquematicamente a montagem do aparato experimental utilizado neste trabalho.

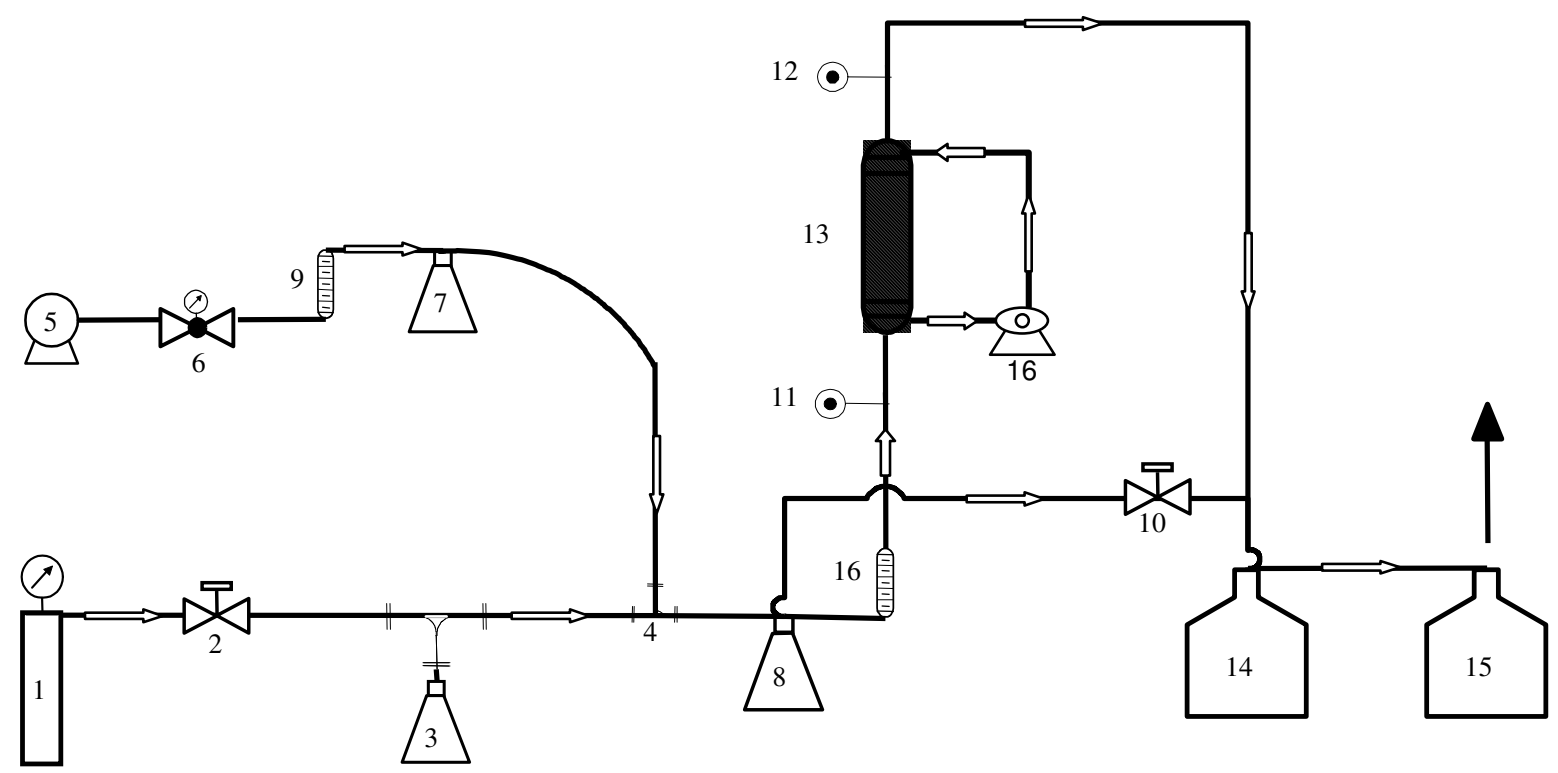

Figura 9. Montagem do sistema de biofiltração (1) Cilindro de $\mathrm{H}_{2} \mathrm{~S}$ puro; (2) Válvula agulha; (3) Contador de bolhas; (4) Trompa de vácuo para diluição do $\mathrm{H}_{2} \mathrm{~S}$; (5) Compressor; (6) Válvula reguladora de pressão; (7) Umidificador; (8) Misturador; (9 e 16) Rotâmetros; (10) Válvula para acerto da vazão de entrada no reator; (11) Amostrador de entrada; (12) Amostrador de saída; (13) Biofiltro; (14) Inóculo reserva; (15) Tanque de $\mathrm{NaOH},(16)$ Bomba de recirculação.

A vazão da corrente de ar proveniente do compressor (5) era controlada por um registro acoplado na uma válvula reguladora de pressão (6) que mantinha no sistema uma pressão entre 1 e $2 \mathrm{~kg} \cdot \mathrm{cm}^{-2}$ e uma vazão acima de $100 \mathrm{~L} \cdot \mathrm{h}^{-1}$ de acordo com a concentração pretendida. A medida da vazão era realizada através de rotâmetro (9) previamente calibrado.

A umidificação da corrente de ar no sistema era realizada através de um Frasco Duran de 2 L (7), essa corrente gasosa passava por uma mangueira plástica, sendo que, na ponta dessa mangueira, havia uma pedra porosa com o intuito de aumentar a superfície de contato do ar com a água. A corrente umidificada era coletada na parte superior do frasco e seguia no sistema. 
Uma foto do sistema de umidificação é mostrado na Figura 10

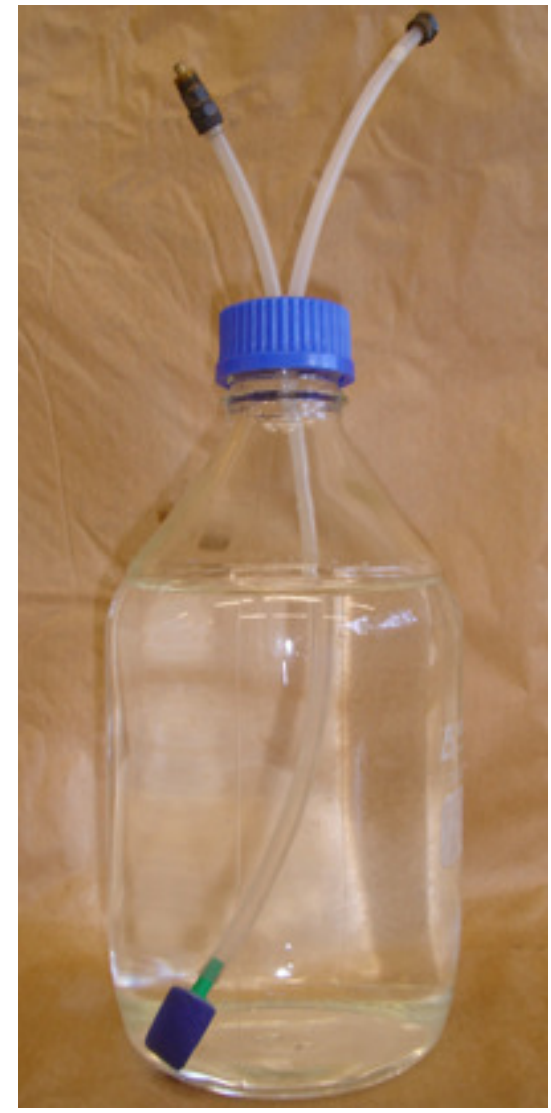

Figura 10. $\quad$ Sistema de umidificação

$\mathrm{O}_{2} \mathrm{~S}$ fornecido ao sistema foi proveniente de um cilindro de $\mathrm{H}_{2} \mathrm{~S}$ puro (1), sua vazão foi controlada através de uma válvula de agulha (2) feita em aço inox e ajustada através da contagem de bolhas de $\mathrm{H}_{2} \mathrm{~S}$ por minuto em um Frasco Duran (3) contendo água destilada. A contagem das bolhas era realizada desviando-se o $\mathrm{H}_{2} \mathrm{~S}$ para o sistema uma vez por semana ou quando as concentrações de sulfeto na entrada apresentavam valores fora da faixa pretendida, e sua concentração no sistema era determinada experimentalmente, através de medidas antes da entrada no biofiltro.

O Frasco Duran para contagem de bolhas (3) continha um tubo plástico que ia até o fundo, semelhante ao sistema de umidificação, mas na ponta do tudo foi acoplado um tubo de vidro de menor diâmetro interno para obter-se uma melhor contagem das bolhas.

As duas correntes gasosas (ar comprimido e sulfeto) eram unidas através de um “Te" em inox (4), seguindo para um Frasco Duran (8) onde ocorria a subdivisão da corrente resultante, uma parcela de $100 \mathrm{~L} . \mathrm{h}^{-1}$, medida através de um rotâmetro (16) e regularizada através de uma válvula (10), seguia para a alimentação do biofiltro (13), e a 
outra com o restante da vazão, alimentava o barrilete com inóculo reserva (14). As correntes após o barrilete de inóculo seguiam por segurança para um barrilete contento $\mathrm{NaOH}$ 0,3 M (15), para retenção do $\mathrm{H}_{2} \mathrm{~S}$ restante e após esse barrilete as correntes eram descartadas fora do laboratório.

O biofiltro utilizado foi construído com uma coluna de acrílico, dividida em 3 módulos, $2 \mathrm{com} 13 \mathrm{~cm}$ de altura e um central com $50 \mathrm{~cm}$, totalizando uma altura do leito de $76 \mathrm{~cm}$ e o diâmetro interno era de $5,2 \mathrm{~cm}$. Nas extremidades superiores e inferiores do biofiltro foram acoplados módulos para a distribuição e captação da corrente gasosa e também para a recirculação da fase líquida.

Uma foto das partes do biofiltro desmontado é apresentada na Figura 11.

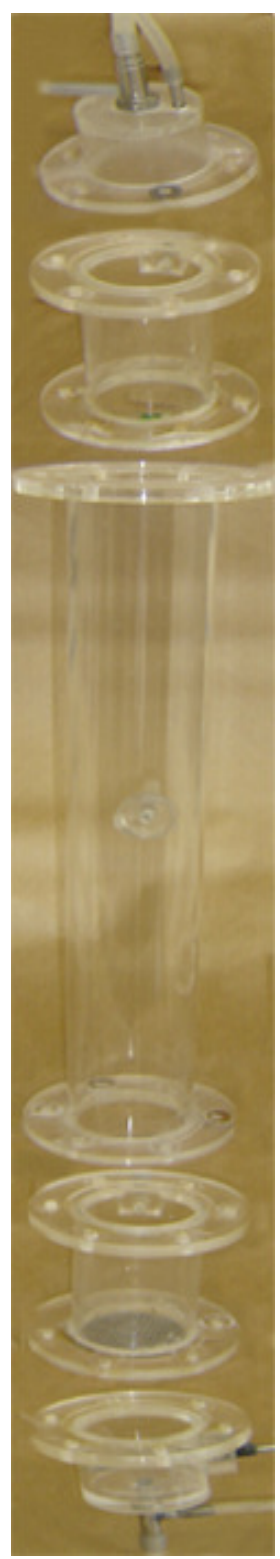

Figura 11. Partes do biofiltro desmontado 
$\mathrm{Na}$ parte inferior do leito foi acomodado uma placa de aço inox perfurada para prover uma melhor distribuição do gás e sustentar o recheio e a corrente gasosa era distribuída abaixo dessa placa por um tubo de aço inox horizontal perfurado por onde se dava entrada da corrente gasosa contaminada com $\mathrm{H}_{2} \mathrm{~S}$.

Na parte inferior do módulo de entrada do reator foi acoplado um "Te" em aço inox por onde era coletado o percolado e feita a alimentação do reator.

Uma Foto da parte inferior do reator é mostrado na Figura 12.

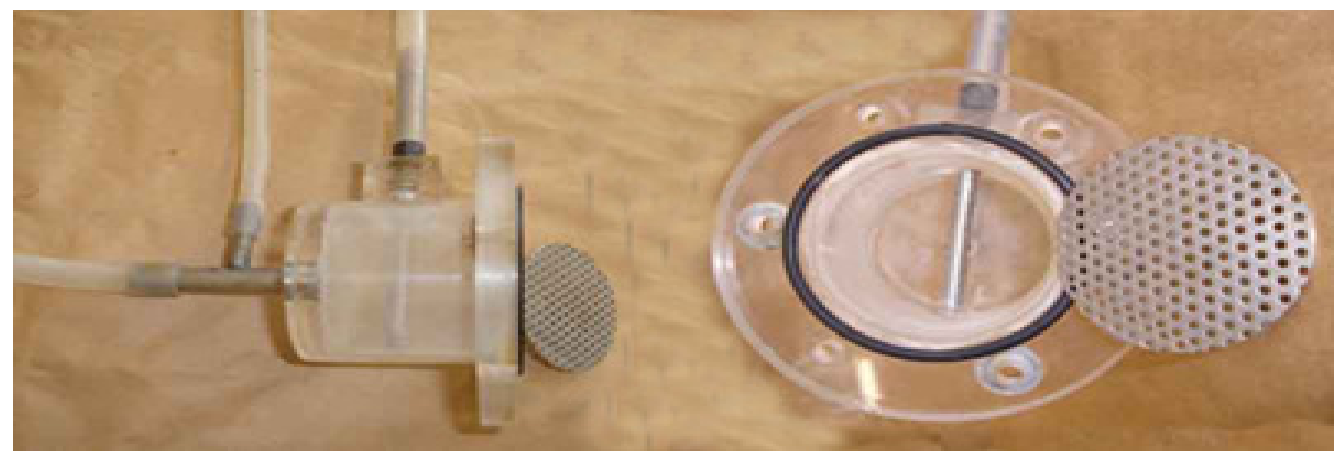

Figura 12. Módulo inferior do Biofiltro

Na parte inferior do reator, conectou-se uma bomba dosadora ligada a um timer. A bomba foi programada com o auxilio do timer sendo ativada por 5 minutos em intervalos de 6 horas, para manter uma distribuição uniforme da umidade no interior do reator e fazer uma reinoculação do reator com os microrganismos que eram "carregados" junto com o percolado.

A Figura 13 mostra o biofiltro com seu sistema de recirculação. 


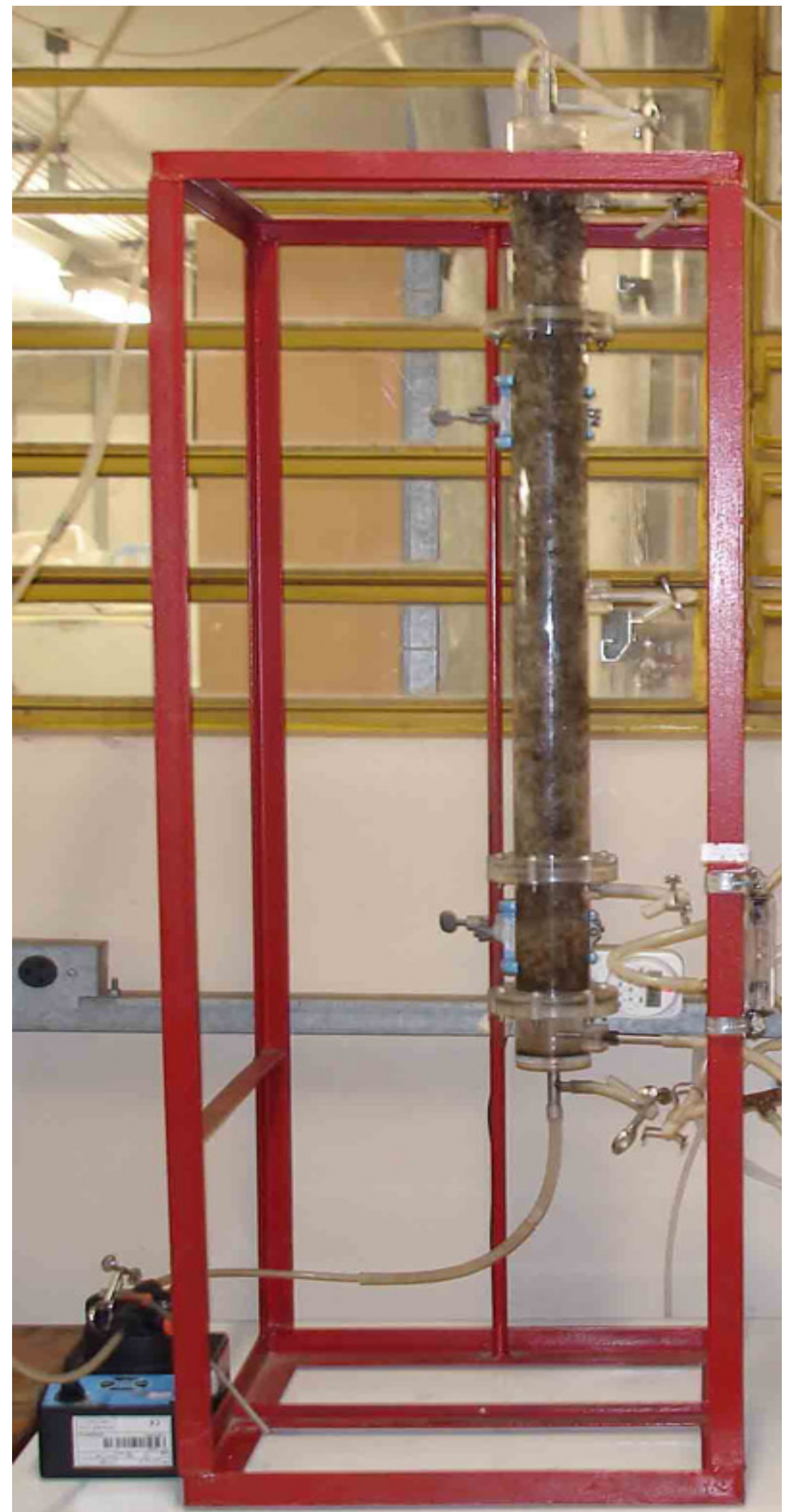

Figura 13. Biofiltro. 
O módulo superior contém um tubo de inox para saída de gases e, no centro, um atomizador spray para promover a umidificação e nutrição do meio, quando estas foram necessárias.

Uma Foto da parte superior do reator é mostrado na Figura 14.

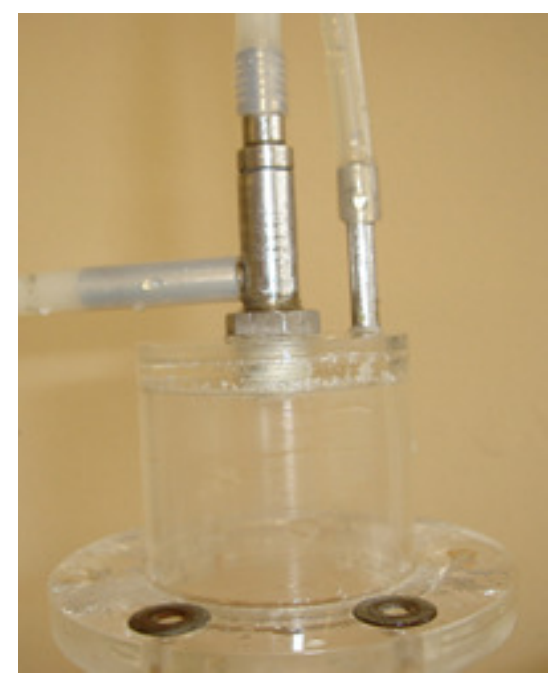

Figura 14. Parte superior do biofiltro

Como a vazão da corrente de ar contaminado era superior à vazão de alimentação do reator, utilizou-se um sistema de mistura feito em frasco Duran de $500 \mathrm{~mL}$, com o auxilio de um registro e um rotâmetro previamente calibrado. Uma parte era utilizada para a alimentação do reator e a outra parte da vazão era utilizada para a manutenção de uma reserva de inoculo adaptado.

O sistema para a manutenção do inóculo adaptado ao sulfeto era composto por um barrilete de $50 \mathrm{~L}$, sendo que a corrente gasosa em excesso entrava pela tampa junto com a corrente gasosa da saía do reator $\left(100 \mathrm{~L}^{-\mathrm{h}^{-1}}\right)$. As correntes entravam no barrilete por uma mangueira que alcançava o fundo do barrilete e possuía uma pedra porosa na ponta.

$\mathrm{O}$ sistema de segurança para contenção de odores e residuais efluentes de $\mathrm{H}_{2} \mathrm{~S}$ era constituído por um barrilete de $20 \mathrm{~L}$, para onde toda a corrente gasosa do sistema e do sistema de manutenção do inóculo era enviada antes do descarte final. Dentro do barrilete, a corrente gasosa foi distribuída na parte inferior através de uma pedra porosa e a solução utilizada para a coleta do $\mathrm{H}_{2} \mathrm{~S}$ foi uma solução de $\mathrm{NaOH}$ de $0,3 \mathrm{M}$. O descarte do ar que passava pelo sistema de segurança era coletado por uma mangueira e descartado fora do laboratório. 
A Figura 15 mostra uma foto geral de todo o sistema.

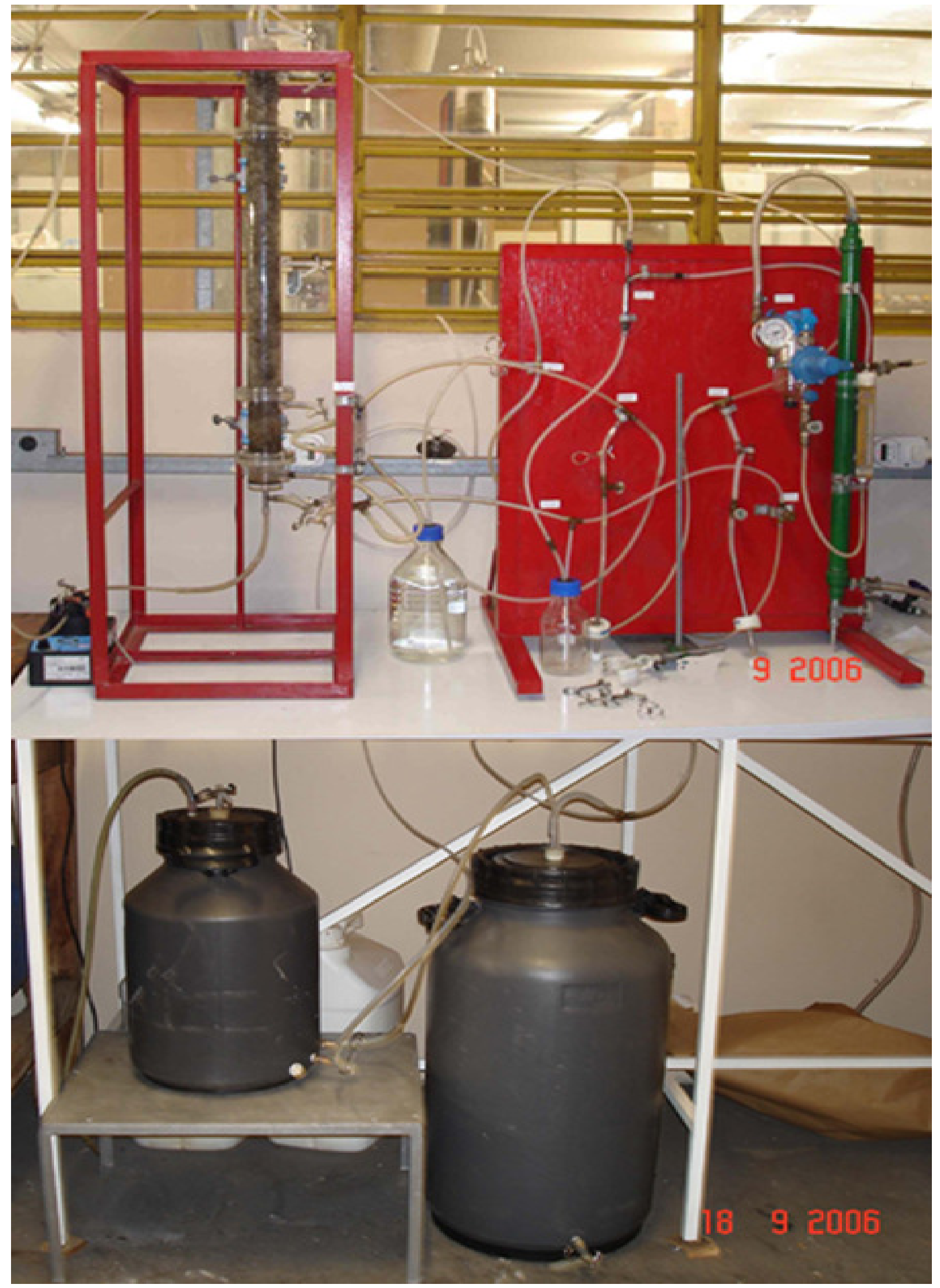

Figura 15. Visão geral do sistema 


\subsection{Ensaios hidrodinâmicos}

São inúmeras as correlações para se prever a queda de pressão em função da vazão produzida em um leito com enchimento. As mais tradicionais utilizadas em biofiltros são as de DARCY e ERGUN.

A equação de DARCY é apresentada na eq. 15.

$$
\frac{\Delta \mathrm{P}}{\mathrm{L}}=\frac{\mu}{\mathrm{K}} \cdot \mathrm{v}
$$

Onde;

$\Delta \mathrm{P}$ : queda de pressão [dina.cm ${ }^{-2}$ ]

$\mathrm{L}:$ comprimento do leito $[\mathrm{cm}]$

$\mu$ : viscosidade do fluido $\left[\mathrm{g} \cdot \mathrm{cm}^{-1} \cdot \mathrm{s}^{-1}\right]$

$\mathrm{K}$ : permeabilidade do meio poroso $\left[\mathrm{cm}^{-2}\right]$

$\mathrm{v}$ : velocidade superficial $\left[\mathrm{cm} \cdot \mathrm{s}^{-1}\right]$

A equação de ERGUN (1952) é apresentada na eq. 16.

$$
\frac{\Delta \mathrm{P}}{\mathrm{L}}=150 \cdot \frac{\left(1-\varepsilon_{\text {leito }}\right)^{2}}{\varepsilon_{\text {leito }}{ }^{3}} \frac{\mu \mathrm{v}}{\left(\gamma \mathrm{D}_{\mathrm{EQ}}\right)^{2}}+1,75 \cdot \frac{\left(1-\varepsilon_{\text {leito }}\right)}{\varepsilon_{\text {leito }}{ }^{3}} \frac{\rho \mathrm{v}^{2}}{\gamma \mathrm{D}_{\mathrm{EQ}}}
$$

Onde:

$\varepsilon_{\text {leito }}=$ Porosidade do leito

$\mu=$ Viscosidade o ar a $25^{\circ} \mathrm{C}\left[\right.$ dyn.s.cm $\left.{ }^{-2}\right]$

$\mathrm{v}=$ Velocidade superficial $\left[\mathrm{cm} \cdot \mathrm{s}^{-1}\right]$

$\gamma=$ Esfericidade

$\mathrm{D}_{\mathrm{EQ}}=$ Diâmetro da Partícula ou da esfera equivalente $[\mathrm{cm}]$ 


$$
\rho=\text { Massa específica do ar a } 25^{\circ} \mathrm{C}\left[\mathrm{g} . \mathrm{cm}^{-3}\right]
$$

$\mathrm{O}$ diâmetro equivalente das partículas, $\mathrm{D}_{\mathrm{EQ}}$, pode ser definido de inúmeras formas. Uma delas segundo Foust et al. (1982) é apresentada na eq. 17

$$
\mathrm{D}_{\mathrm{EQ}}=6 \cdot\left(\frac{\mathrm{V}_{\mathrm{P}}}{\mathrm{S}_{\mathrm{P}}}\right)
$$

Onde $\mathrm{V}_{\mathrm{P}} / \mathrm{S}_{\mathrm{P}}$ é o volume da razão de área superficial pelo sistema de partículas (L). Alternativamente, $\mathrm{D}_{\mathrm{EQi}}$ também é definido na eq. 18 como:

$$
\mathrm{D}_{\mathrm{EQ}}=\gamma \mathrm{D}_{\mathrm{V}}
$$

Onde $\gamma$ é a esfericidade ou a área superficial da esfera hipotética para a área de superfície média das partículas atuais e $\mathrm{D}_{\mathrm{V}}$ é o diâmetro médio de diferentes esferas hipotéticas tendo um volume médio das partículas atuais. As equações 17 e 18 permitem estimar o diâmetro individual das partículas.

A porosidade do leito é definida segundo a eq 19.

$$
\varepsilon_{\text {leito }}=\frac{V_{v}}{V_{t}}=\frac{V_{t}-V_{\text {esp }}}{V_{t}}
$$

Onde:

$$
\varepsilon_{\text {leito }}=\text { Porosidade do leito }
$$

$\mathrm{V}_{\mathrm{v}}=$ Volume de vazios $\left[\mathrm{cm}^{3}\right]$

$\mathrm{V}_{\mathrm{t}}=$ Volume total do leito $\left[\mathrm{cm}^{3}\right]$

$\mathrm{V}_{\text {espuma }}=$ Volume da espuma $\left[\mathrm{cm}^{3}\right]$

Os ensaios de fluidodinâmica foram realizados nas colunas de espuma de poliuretano seca, úmida e após o termino da operação do sistema. 
Após o empacotamento, as colunas foram conectadas ao sistema e a perda de carga foi determinada por manômetro inclinado com água na coluna, ligado à saída própria para tal finalidade.

As tomadas de pressão se localizavam nos extremos da coluna, para permitir que altura efetiva do leito pudesse ser utilizada como a altura das tomadas de pressão. A coluna foi totalmente preenchida com o material a ser estudado de forma a manter a altura do leito aproximadamente igual para todas as medições. Para cada réplica, as massas empacotadas foram as mesmas da utilizada no experimento $(27,16 \mathrm{~g})$ para que a densidade global do leito fosse mantida a mesma em todas as réplicas.

As colunas foram alimentadas com uma corrente de ar comprimido proveniente de um compressor e previamente reguladas por válvulas de pressão. A vazão do gás foi aferida por um manômetro em "U" acoplado a uma placa de orifício devidamente calibrada.

As medidas de perda de carga foram obtidas variando-se a vazão de ar na entrada da coluna e avaliando o efeito dessa mudança no manômetro acoplado reator, verificandose assim a sua perda de carga em "cm de coluna de água".

Uma vez em posse dos dados de perda de carga e vazão, foi feita a regressão linear das curvas obtidas e com esse resultado e utilizando a equação de DARCY (eq. 15), obteve-se a permeabilidade do leito.

Os valores da perda de carga para a espuma seca também foram calculados através da equação de ERGUN (eq. 16). Para tanto, foram utilizados os valores experimentais de porosidade do leito, velocidade superficial, esfericidade e diâmetro equivalente.

\subsection{Análise de sulfeto}

A análise de sulfeto foi realizada com um kit da $\mathrm{HACH}$, que é baseado no método do azul de metileno (APHA, 1986).

A corrente gasosa a ser analisada era borbulhada em um frasco contendo $50 \mathrm{~mL}$ de solução $0,3 \mathrm{M}$ de $\mathrm{NaOH}$ durante o tempo de um minuto. Adicionava-se $1 \mathrm{~mL}$ de solução 
de acetato de zinco e amostra era então ligeiramente agitada ficando em repouso por 15 minutos.

Decorrido o tempo de reação (15 minutos), $1 \mathrm{~mL}$ da amostra era transferido para um balão de $50 \mathrm{~mL}$ e completava-se o volume do balão.

Feita a diluição, transferia-se $25 \mathrm{~mL}$ da amostra diluída para proveta de $25 \mathrm{~mL}$ e fazia-se a adição dos reagentes 1 e 2 do kit da HACH. Esperava-se o tempo de reação de 5 minutos e se realizava a leitura da concentração no espectrofotômetro. As leituras do espectro eram fornecidas em $\mathrm{mg} \cdot \mathrm{L}^{-1}$.

As relações fornecidas por Rodrigres (2002b) eram utilizadas para se converter a concentração encontrada no espectro para a concentração real da amostra também em mg.L -1 $^{-1}$ Eq. 20) e em seguida essa concentração era convertida para ppm (Eq. 21).

$\mathrm{C}_{(\mathrm{mg} / \mathrm{L})}=\frac{\mathrm{C}_{\mathrm{E}} \cdot \mathrm{D} \cdot \mathrm{V}_{(\mathrm{L})}}{\mathrm{Q}_{(\mathrm{L} / \mathrm{h})} \cdot \mathrm{t}_{(\mathrm{h})}}$

Onde:

$\mathrm{C}_{\mathrm{E}}$ : Concentração lida no espectrofotômetro $\left(\mathrm{mg} \cdot \mathrm{L}^{-1}\right)$;

D: Fator de diluição da amostra;

$\mathrm{V}_{(\mathrm{L})}$ : Volume da amostra (L);

Q: Vazão da corrente gasosa $\left(L \cdot h^{-1}\right)$;

t: Tempo de coleta da amostra (h).

$\mathrm{C}_{\mathrm{H}_{2} \mathrm{~S}(\mathrm{ppm})}=\mathrm{C}_{\left(\mathrm{mg} / \mathrm{m}^{3}\right)} \cdot \frac{24,44}{\mathrm{~mol}_{\mathrm{H}_{2} \mathrm{~S}}}$

Onde:

$\mathrm{C}_{(\mathrm{mg} / \mathrm{m} 3)}$ : Concentração calculada na eq. (24) $\left(\mathrm{C}_{\mathrm{mg} / \mathrm{L}}\right)$ dividida por $10^{6}\left[\mathrm{mg} \cdot \mathrm{m}^{-3}\right]$;

24,44: Volume molar corrigido para $1 \mathrm{~atm}$ e $25^{\circ} \mathrm{C}\left[\mathrm{L} \cdot \mathrm{mol}^{-1}\right]$; 
Mol $_{\mathrm{H} 2 \mathrm{~S}}$ : Massa molecular do $\mathrm{H}_{2} \mathrm{~S}\left[\mathrm{mg} \cdot \mathrm{mol}^{-1}\right]$.

\subsection{Ensaio de Adsorção}

Tomando como base os dados de adsorção de Moe e Irvine (2000a) realizou-se uma primeira coleta das concentrações de entrada e saída com 15 minutos de operação do ensaio de adsorção sendo o restante das análises de concentrações do $\mathrm{H}_{2} \mathrm{~S}$ realizadas na entrada $\left(\mathrm{C}_{\mathrm{e}\left(\mathrm{H}_{2} \mathrm{~S}\right)}\right)$ e na saída $\left(\mathrm{C}_{\mathrm{s}\left(\mathrm{H}_{2} \mathrm{~S}\right)}\right)$ da coluna conforme os intervalos apresentados na Tabela 9.

TABELA 9 - Freqüência de análises no ensaio de adsorção.

\begin{tabular}{lc}
\hline & Tempos \\
\hline $\mathrm{C}_{\mathrm{e}(\mathrm{H} 2 \mathrm{~S})}$ & 15 minutos, 2, 8, 18, 20, 24, 30 e 50 horas \\
$\mathrm{C}_{\mathrm{s}\left(\mathrm{H}_{2} \mathrm{~S}\right)}$ & 15 minutos, $1,2,4,6,8,10,18,20,22,24,26,28,30$ e 50 horas \\
\hline
\end{tabular}

Os testes de adsorção foram realizados empacotando-se uma coluna seca contendo a mesma massa de espuma utilizada na operação do biofiltro $(27,16 \mathrm{~g})$, para que a quantidade de sulfeto adsorvida pudesse ser subtraída da concentração tratada biologicamente. Foi realizado paralelamente, o ajuste da concentração do $\mathrm{H}_{2} \mathrm{~S}$ (275 ppm, concentração equivalente a da segunda fase de operação do sistema). As vazões do ar foram fixas em $100 \mathrm{~L} \cdot \mathrm{h}^{-1}$ (vazão de operação do sistema).

Com o intuito de se minimizarem perturbações e variações bruscas nas concentrações de entrada da coluna de adsorção, devido ao intervalo de tempo que a coluna ficaria sem alimentação durante a amostragem, preferiu-se aumentar os intervalos de amostragem das concentrações de entrada. Para efeito de cálculo, nas concentrações de entrada em que não se tinha os pontos amostrados realizou-se uma média entre as concentrações anteriores e posteriores.

Como medida de segurança durante o ensaio de adsorção, toda a corrente gasosa após passar pela coluna era borbulhada em um barrilete de $25 \mathrm{~L}$ contendo $18 \mathrm{~L}$ de solução de $\mathrm{NaOH}$ 0,3 M, para a retenção do $\mathrm{H}_{2} \mathrm{~S}$ e após a passagem pelo hidróxido de sódio a corrente era descartada fora do laboratório. 


\subsection{Operação contínua do biofiltro}

Com o inóculo adaptado conforme descrito no item 4.2 e utilizando a espuma de poliuretano descrita no item 4.3 foi realizada a inoculação e o empacotamento do recheio do biofiltro conforme descrito pelo item 4.4.

A alimentação do biofiltro foi realizada diariamente, com aproximadamente $50 \mathrm{~mL}$ de solução nutriente preparada conforme descrito na Tabela 8 do item 4.1, mas sem a adição de $\mathrm{Na}_{2} \mathrm{~S}_{2} \mathrm{O}_{3}$ para que a única fonte de sulfeto no reator fosse o $\mathrm{H}_{2} \mathrm{~S}$, a solução também era acrescida de 50 g. $\mathrm{L}^{-2}$ de bicarbonato de sódio $\left(\mathrm{NaHCO}_{3}\right)$, para se elevar a alcalinidade no biofiltro, com a intenção de sempre se manter o $\mathrm{pH}$ no interior da coluna de biofiltração na faixa de 6 a 8 .

Durante a operação do biofiltro, foram realizadas medidas diárias do $\mathrm{pH}$ do percolado, coletado antes da alimentação do sistema.

Como o equipamento utilizado para controlar a vazão de sulfeto não mantinha uma vazão constante e a vazão de ar também variava conforme ocorriam oscilações na pressão do compressor, as concentrações de entrada $\left(\mathbf{C}_{\mathbf{H} 2 \mathbf{S}}\right)$ em cada uma das sete fases são apresentadas em valores médios, como mostrados na Tabela 10.

TABELA 10 - Duração das fases do sistema e suas concentrações médias.

\section{Fase Duração (dias) Período (dias) $\quad \mathbf{C}_{\mathrm{H}_{2} \mathrm{~S}}$ Média (ppm)}

\begin{tabular}{cccc}
\hline I & 20 & $1^{\circ}-20^{\circ}$ & 141 \\
II & 14 & $21^{\circ}-34^{\circ}$ & 271 \\
III & 9 & $35^{\circ}-43^{\circ}$ & 514 \\
IV & 13 & $44^{\circ}-56^{\circ}$ & 532 \\
V & 17 & $57^{\circ}-73^{\circ}$ & 581 \\
VI & 21 & $74^{\circ}-94^{\circ}$ & 878 \\
Paralisação & 14 & $95^{\circ}-108^{\circ}$ & - \\
VII & 13 & $109^{\circ}-121^{\circ}$ & 1303 \\
\hline
\end{tabular}

O sistema foi operado continuamente por 42 dias. No $43^{\circ}$ dia ocorreram problemas operacionais (quebra do biofiltro). Corrigidos os problemas voltou-se novamente a operação do sistema até o $94^{\circ}$ dia, quando foi realizada uma paralisação da alimentação do 
$\mathrm{H}_{2} \mathrm{~S}$ no sistema, sendo apenas fornecido a corrente gasosa e a solução de alimentação até o $108^{\circ}$ dia. A paralisação foi realizada com o intuito de se verificarem os efeitos de uma paralisação temporária e a capacidade do sistema em voltar a operar com uma concentração de sulfeto superior a utilizada anteriormente. Terminada a paralisação do sistema, o $\mathrm{H}_{2} \mathrm{~S}$ foi novamente adicionado a corrente gasosa por mais 13 dias, totalizando 121 dias de operação do sistema.

Durante a operação do sistema, foram realizadas cinco vezes por semana as medidas das concentrações de entrada e saída do sistema. As análises eram realizadas em duplicata e quando apresentavam valores discrepantes ou fora da faixa de concentração pretendida as medidas eram realizadas novamente, com o intuito de se verificar se não foram cometidos erros, caso os valores se comprovassem fora da faixa pretendida era realizado um ajuste na concentração, sendo novamente medida após 2 ou 3 horas.

A adoção do intervalo de algumas horas, entre o ajuste na concentração e a nova medida da concentração, foi devida ao elevado tempo de resposta da válvula agulha em fornecer um resultado preciso da sua vazão após ser ajustada.

\subsection{Capacidade de Eliminação, Taxa de Carregamento e Eficiência de Remoção}

A capacidade de eliminação de um composto num dado biofiltro tem um valor máximo $\mathrm{EC}_{\max }$, correspondente à quantidade máxima desse poluente, que pode ser degradado em condição operacionais. Esta característica é muito útil para o dimensionamento dos biofiltros (SWANSON \& LOEHR, 1997). Pode ser utilizada para comparar as performances de biofiltração em casos de diferentes compostos orgânicos e entre diferentes unidades de biofiltração. (JORIO \& HEITZ, 1999).

A capacidade de eliminação tem uma tendência a aumentar com a carga de massa e com a concentração de poluente no gás e a diminuir com o tempo de residência acima de um valor limite o que não só depende da degradabilidade do composto, mas também do tipo de suporte e das condições operacionais (CONVERTI et al., 2001).

A capacidade de eliminação (Ec) é definida como o produto do fluxo gasoso (Q) por volume unitário $(\mathrm{V})$ pela diferença de concentração no afluente e no efluente $\left(\mathrm{C}_{\mathrm{ent}}-\right.$ $\mathrm{C}_{\text {sai }}$ ), fornece uma medida da habilidade do biofiltro em remover os poluentes. Desta 
definição parece evidente que, se a eficiência de remoção desejada é próxima de $100 \%$, a capacidade de eliminação também se torna máxima. (CONVERTI et al., 2001).

A capacidade de eliminação de sulfeto é calculada em função das concentrações de entrada e saída.

A Eq. 22 ilustra a capacidade de eliminação.

$$
\mathrm{Ec}=\frac{\mathrm{Q} \cdot\left(\mathrm{C}_{\mathrm{ent}}-\mathrm{C}_{\mathrm{sai}}\right)}{\mathrm{V}}
$$

Onde:

Ec: Capacidade de eliminação $\left[\mathrm{g} \cdot \mathrm{h}^{-1} \cdot \mathrm{m}^{-3}\right]$;

Q: Vazão de gás $\left[\mathrm{m}^{3} \cdot \mathrm{h}^{-1}\right]$;

$\mathrm{C}_{\mathrm{ent}}:$ Concentração de entrada $\left[\mathrm{g} \cdot \mathrm{m}^{-3}\right]$;

$\mathrm{C}_{\text {sai: }}$ Concentração de saída $\left[\mathrm{g} \cdot \mathrm{m}^{-3}\right]$;

$\mathrm{V}$ : Volume do reator $\left[\mathrm{m}^{3}\right]$

A taxa de carregamento $\left(\mathrm{L}_{\mathrm{S}}\right)$ segundo Oyarzún et al. (2003) é definida na eq. 23

$$
\mathrm{L}_{\mathrm{S}}=\frac{\mathrm{Q} \cdot \mathrm{C}_{\mathrm{ent}}}{\mathrm{V}}
$$

Onde:

$\mathrm{L}_{\mathrm{S}}$ : Taxa de carregamento $\left[\mathrm{g} \cdot \mathrm{h}^{-1} \cdot \mathrm{m}^{-3}\right]$

Q: Vazão de gás $\left[\mathrm{m}^{3} \cdot \mathrm{h}^{-1}\right]$;

$\mathrm{C}_{\mathrm{ent}}:$ Concentração de entrada $\left[\mathrm{g} \cdot \mathrm{m}^{-3}\right]$;

$\mathrm{V}$ : Volume do reator $\left[\mathrm{m}^{3}\right]$ 
A eficiência de remoção do sistema foi calculada a partir das médias dos pontos coletados na entrada e saída do sistema de acordo com a eq. 24.

$$
\eta=\frac{\left(C_{\text {ent }}-C_{\text {sai }}\right)}{C_{\text {ent }}} .100
$$

Onde:

$\eta=$ Eficiência de remoção $[\%]$

$\mathrm{C}_{\text {ent }}=$ Concentração de entrada $[\mathrm{ppm}]$;

$\mathrm{C}_{\mathrm{sai}}=$ Concentração de saída $[\mathrm{ppm}]$

\subsection{Microscopia Óptica.}

A fim de se verificar a existências dessas morfologias foram coletadas amostras do lodo utilizado como inóculo após a fase de adaptação e do percolado, e observadas ao microscópio óptico.

\subsection{Metodologia de preparo das amostras de espuma de poliuretano para Microscopia Eletrônica de Varredura}

O preparo das amostras para a microscopia eletrônica de varredura (MEV) foi realizado de acordo com Araújo, (1995) sendo o procedimento descrito a seguir.

O processo de fixação foi feito com a inserção da espuma numa solução de glutaraldeido (2,5\% em tampão de fosfato) por $12 \mathrm{~h} \mathrm{a} 4{ }^{\circ} \mathrm{C}$. Esta etapa teve por objetivo fixar a morfologia da amostra.

Decorridas $12 \mathrm{~h}$ a espuma passou por um processo de lavagem com uma solução tampão de fosfato $0,1 \mathrm{M}$ com $\mathrm{pH}$ 7,3 durante $10 \mathrm{~min}$, em seguida a espuma passou por um processo de secagem. Realizando-se uma seqüência de lavagens com soluções de etanol, cada uma de 10 minutos: 50\%, 70\%, 80\%, 90\%, 95\% e 100\%, sendo que na solução de $100 \%$ foram efetuadas 3 lavagens de 10 minutos cada. 
Após a secagem com o etanol foi utilizado HMDS (hexametildesilasani), efetuando-se 2 lavagens de $30 \mathrm{~s}$ cada, para o processo final de secagem.

A espuma foi então fixada no suporte para microscopia eletrônica com esmalte base e então submetida ao banho de ouro. 


\section{RESULTADOS E DISCUSSÕES}

\subsection{Ensaios Hidrodinâmicos}

Com a finalidade de verificar-se o efeito da operação do sistema na perda de carga do leito da espuma de poliuretano foram realizados os testes hidrodinâmicos. Portanto, calculou-se através da equação de DARCY a permeabilidade do leito nas espumas secas, úmidas e após 121 dias de operação do sistema, através da regressão linear dos dados obtidos, e utilizando-se para efeito de cálculo a viscosidade do ar a $20^{\circ} \mathrm{C}$ como sendo $1,81.10^{-5}$ N.s.m ${ }^{-2}$ (FOX \& MACDONALD, 2001).

A Figura 16 mostra gráfico com os valores da perda de carga $(\Delta \mathrm{P} / \mathrm{L})$ para a espuma de poliuretano seca em função da velocidade superficial de ar (v) obtidos nos ensaios hidrodinâmicos e a média dos mesmos.

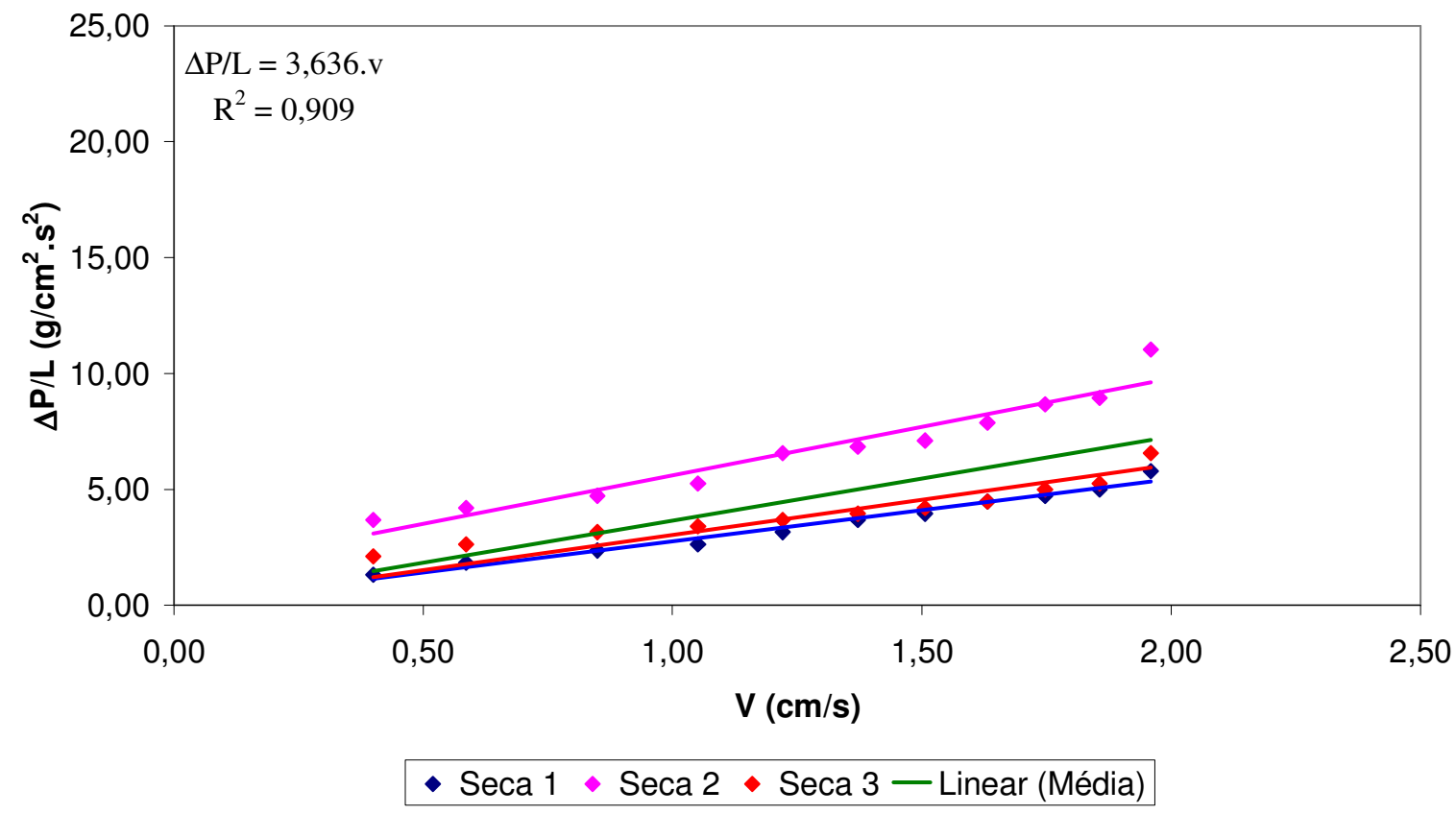

Figura 16. Valores de perda de carga para espuma de poliuretano seca em função da velocidade superficial do ar.

Como pode ser observado na Figura 16, para o leito de espuma de poliuretano seca, os valores de $\Delta \mathrm{P} / \mathrm{L}$ em função de $\mathrm{v}$ apresentam comportamento linear condizente com o previsto pela equação de DARCY. Para um dos ensaios, a equação da reta obtida por 
regressão linear não passou pela origem. Isto ocorreu, provavelmente, devido às dificuldades de reprodutibilidade do empacotamento da espuma seca, que apresentou muita "carga estática" fazendo com que as espumas se agregassem de forma aleatória, dificultando seu manuseio e, ocorrendo no leito regiões um pouco compactadas. Mas, mesmo com as dificuldades decorrentes do empacotamento do leito em cada réplica, as perdas de cargas se mantiveram muito baixas.

A Figura 17 mostra gráfico com os valores da perda de carga para a espuma de poliuretano úmida em função da velocidade superficial de ar obtidos nos ensaios hidrodinâmicos e a média dos mesmos.

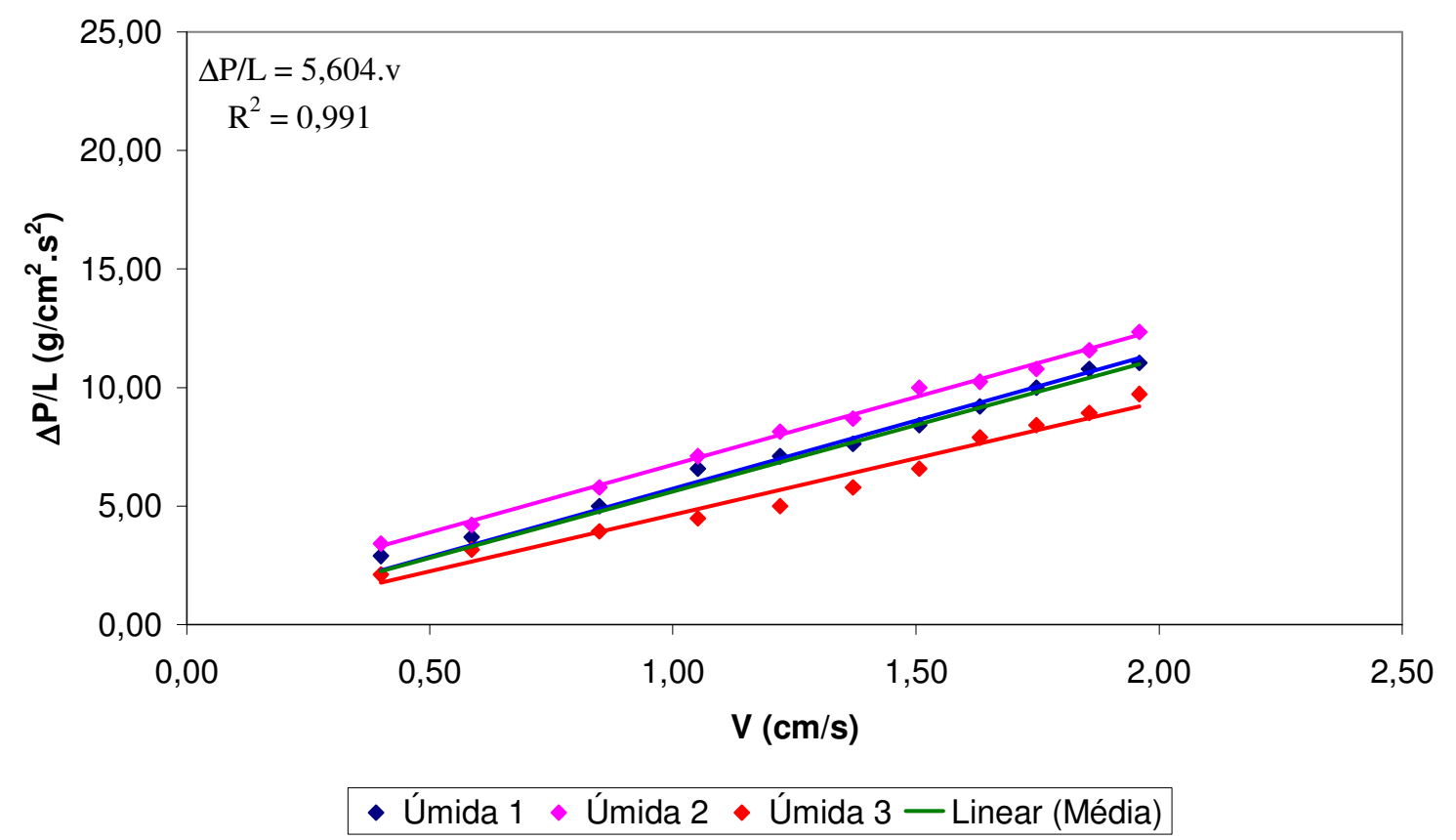

Figura 17. Valores de perda de carga para espuma de poliuretano úmida em função da velocidade superficial de ar.

Na Figura 17, o gráfico da perda de carga para a coluna úmida tem uma melhor reprodutibilidade dos pontos, pois com a espuma úmida não ocorreu "carga estática", fornecendo assim uma melhor acomodação da espuma no leito e uma maior facilidade de empacotamento do mesmo. Na coluna úmida a regressão linear dos pontos amostrados passa pela origem o que demonstra um melhor ajuste dos pontos para o calculo da perda de carga através da equação de DARCY. 
A Figura 18 mostra um gráfico comparativo entre os valores da perda de carga para a espuma de poliuretano utilizada no biofiltro para o tratamento de $\mathrm{H}_{2} \mathrm{~S}$, após 121 dias de operação, em função da velocidade superficial de ar obtidos nos ensaios hidrodinâmicos e a média dos mesmos.

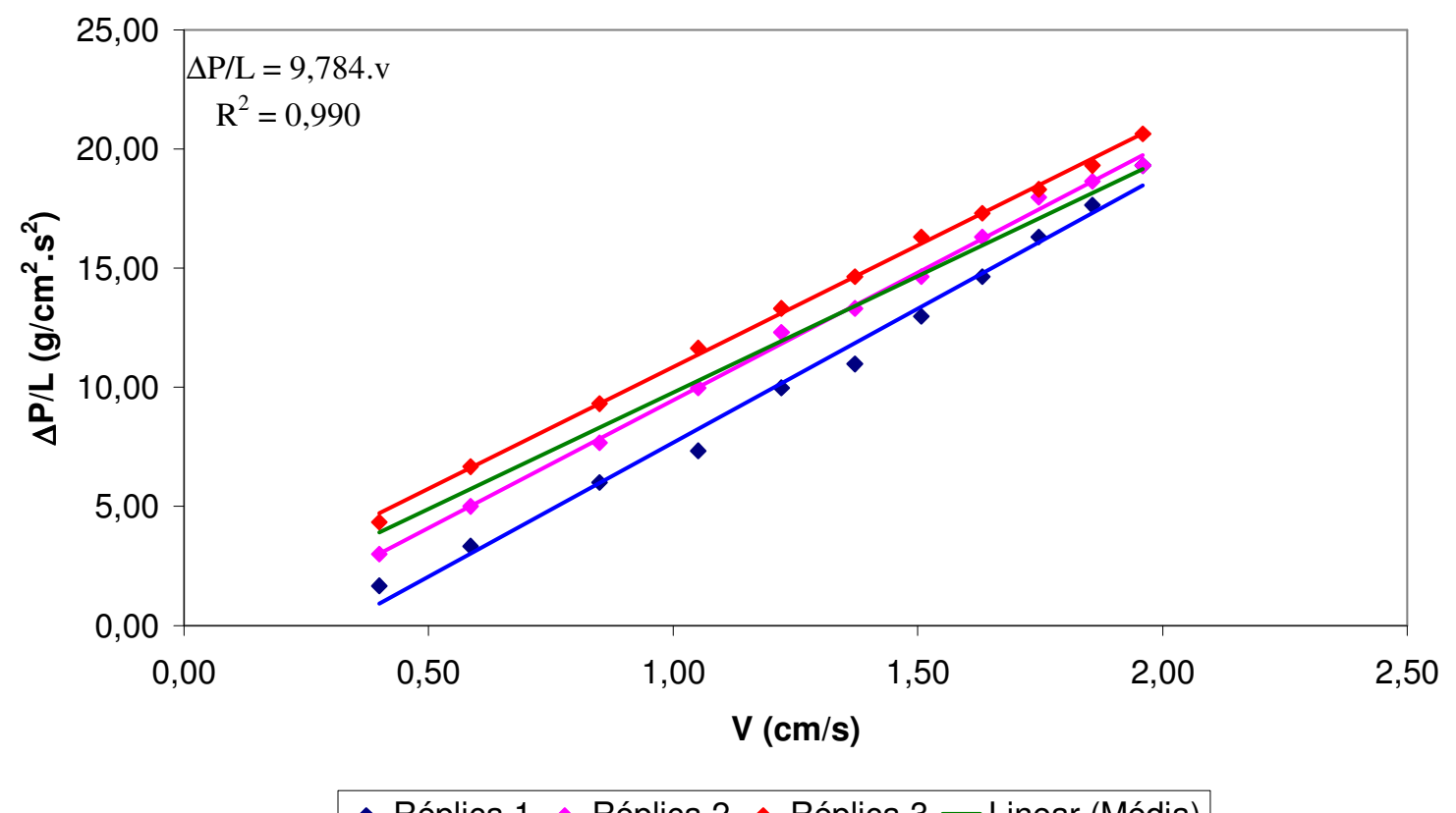

Figura 18. Valores de perda de carga para espuma de poliuretano com 121 dias de operação no biofiltro em função da velocidade superficial de ar.

Nota-se pelo gráfico da Figura 18 que a perda de carga no sistema aumentou, mas ainda assim se tem baixos valores de perda de carga (valor de $\Delta \mathrm{P} / \mathrm{L}$ equivalente a 12,80 $\mathrm{g} / \mathrm{cm}^{2} . \mathrm{s}^{2}$ que corresponde a $0,78 \cdot 10^{-2} \mathrm{mca}$, para a velocidade superficial de operação) e um bom ajuste dos pontos para o cálculo da permeabilidade do leito ser feita por DARCY, considerando-se uma altura do leito de $60 \mathrm{~cm}$.

A Figura 19 mostra um gráfico com os valores médios das perdas de carga obtidas nas espumas secas, úmidas, após 121 dias de operação considerando no gráfico as alturas do leito como sendo $76 \mathrm{~cm}$ (altura inicial) e $60 \mathrm{~cm}$ (altura após a colmatação do leito). Também foi calculada estimativa de perda de carga através da equação de ERGUN. 


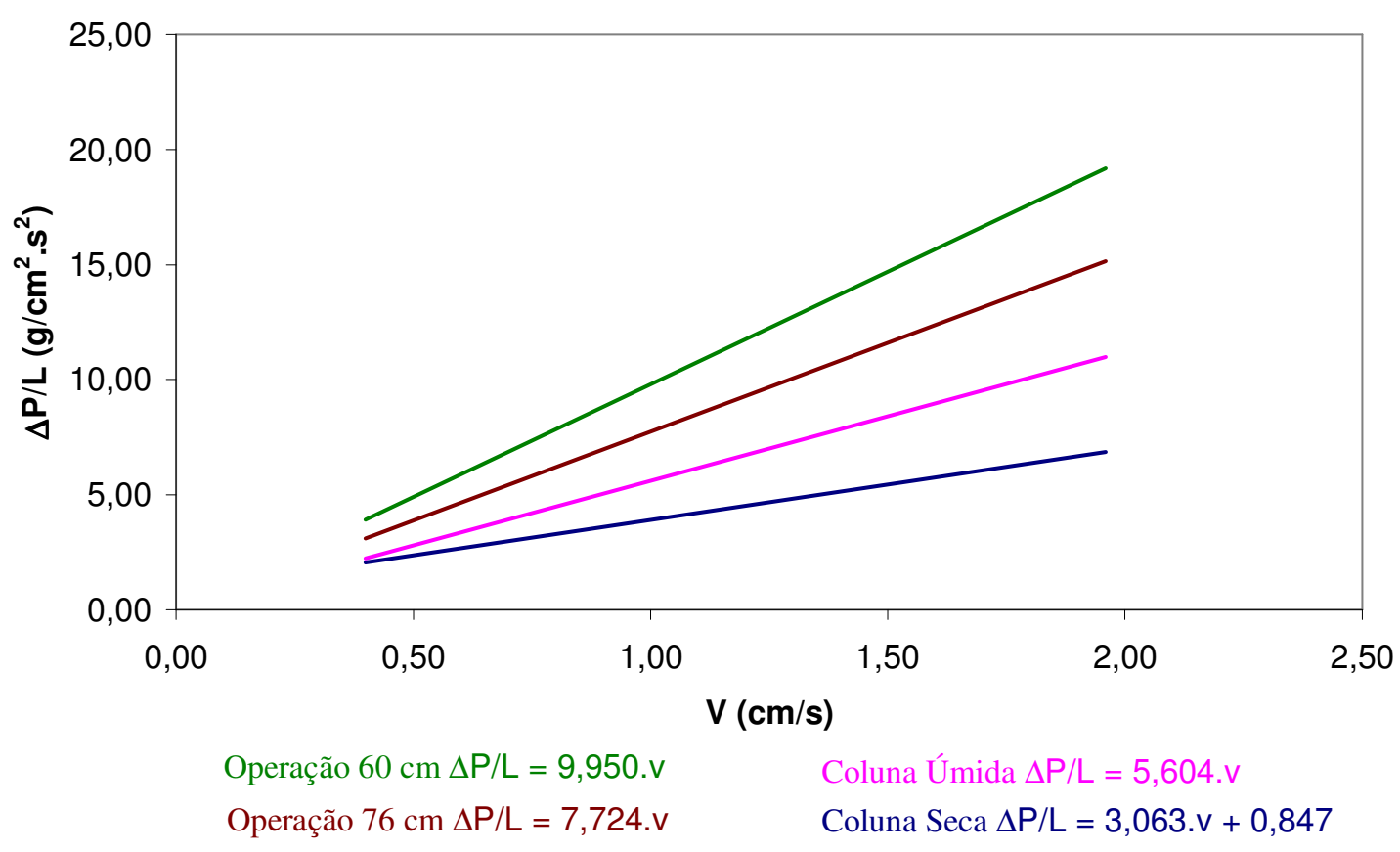

Figura 19. Comparação dos valores das perdas de cargas seca, úmida, após a operação do sistema considerando alturas do leito de 60 e $76 \mathrm{~cm}$ em função da velocidade superficial do ar.

A Figura 19 mostra que mesmo considerando a altura do leito como constante (76 $\mathrm{cm}$ ) ocorreu uma redução da permeabilidade e conseqüente aumento da perda de carga se comparado com o leito de espuma úmido, indicando assim que uma parte do aumento da perda de carga foi devido à colmatação do leito, mas parte do aumento da perda de carga foi devido ao crescimento dos microrganismos, acúmulo de enxofre, enrijecimento da espuma e outros fatores físicos.

A Figura 20 mostra um gráfico comparativo dos dados de perda de carga para a espuma seca calculados por DARCY e por ERGUN em função da velocidade superficial. 


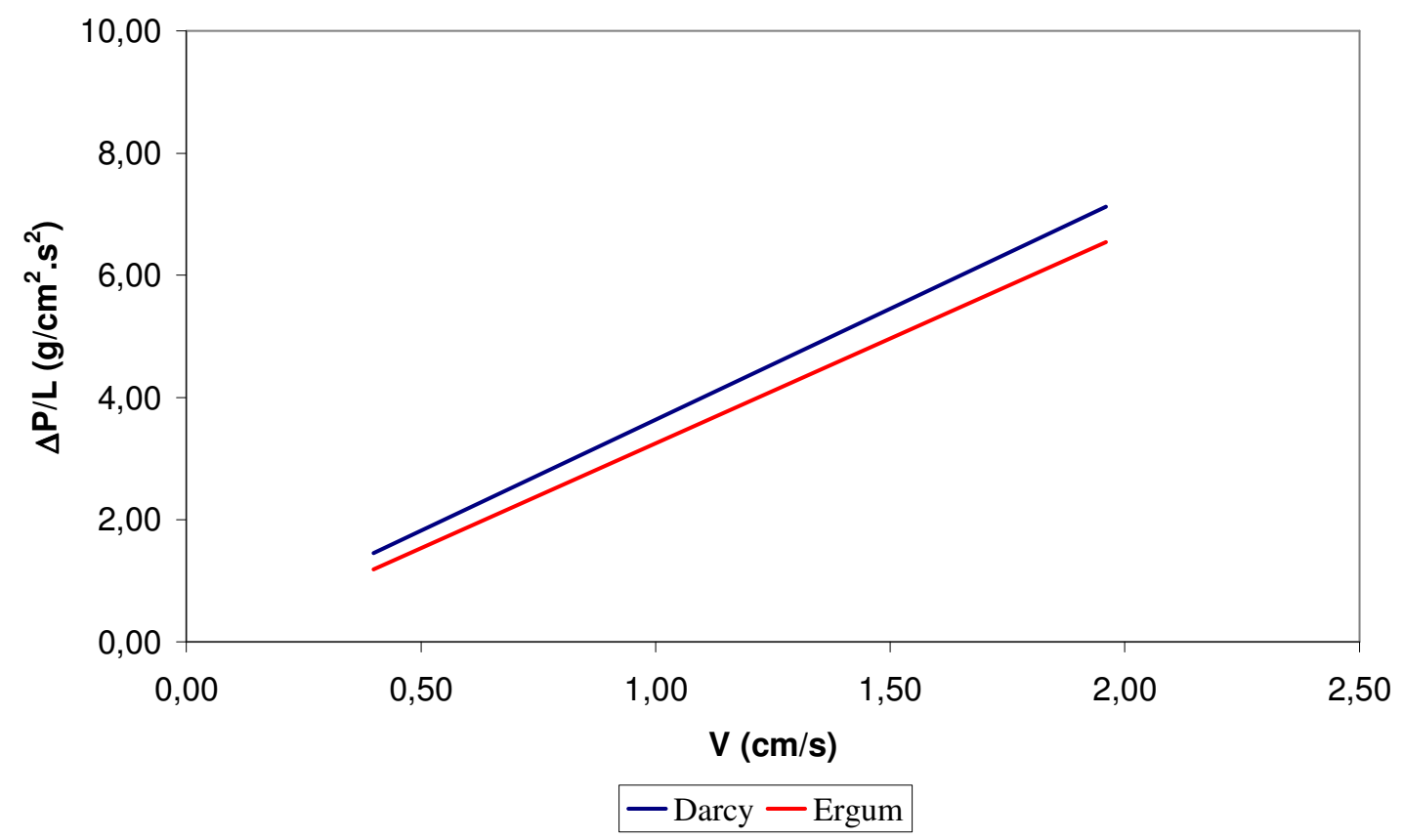

Figura 20. Comparação dos valores das perdas de cargas seca calculada por Darcy e por ERGUN em função da velocidade superficial de ar.

A Figura 20 mostra que a equação de ERGUN resulta em valores muito próximos aos encontrados através de DARCY para a espuma seca. Assim, para baixas velocidades o termo quadrático na equação de ERGUN apresenta pouca influência, aproximando-se da equação de DARCY e o ajuste realizado em DARCY, para que esse passasse pela origem é válido para se estimar a perda de carga do sistema, em coluna de espuma seca, na faixa de valores de velocidade ensaiados.

A Tabela 11 mostra um comparativo das permeabilidades obtidas nos ensaios com as espumas secas, úmidas, no leito após a desativação do sistema.

TABELA 11 - Permeabilidades do leito obtida graficamente.

\begin{tabular}{cccc}
\hline \multirow{2}{*}{ Coluna } & \multicolumn{3}{c}{$\Delta \mathrm{P} / \mathrm{L}$ em função da velocidade superficial $(\mathrm{V})$} \\
& Regressão & $\mathrm{K}\left(\mathrm{cm}^{2}\right)$ & $\mathrm{R}^{2}$ \\
\hline Seca & $3,636 . \mathrm{v}$ & $1,41 \mathrm{E}-04$ & 0,909 \\
Úmida & $5,604 . \mathrm{v}$ & $9,17 \mathrm{E}-05$ & 0,991 \\
Biofiltro $60 \mathrm{~cm}$ & $9,950 . \mathrm{v}$ & $5,25 \mathrm{E}-05$ & 0,990 \\
Biofiltro 76 cm & $7,724 . \mathrm{v}$ & $6,65 \mathrm{E}-05$ & 0,990 \\
\hline
\end{tabular}

Como esperado, após a inoculação da espuma e 121 dias de operação do biofiltro nota-se também a redução da permeabilidade do leito. 
Utilizando-se dos dados de densidade ( $\rho_{\text {espuma }}$ ) da espuma de poliuretano como sendo $0,023 \mathrm{~g} \cdot \mathrm{cm}^{-3}$ (MAIA, 2003), a massa especifica da água a $25^{\circ} \mathrm{C}$ ( $\rho_{\text {água }}$ ) como 0,997 g. $\mathrm{cm}^{-3}$ (FOX \& MACDONALD, 2001), calculou-se com a Tabela 12 a porosidade do leito e da espuma.

TABELA 12 - Porosidade do leito e da espuma.

\begin{tabular}{lccc}
\hline & \multicolumn{2}{c}{ Espuma } & \multirow{2}{*}{ Leito } \\
\hline Massa de 50 espumas secas (g) & Método 1 & Método 2 & \\
Massa de 1 espuma seca (g) & 0,133 & 0,9718 & - \\
Massa total de espuma (g) & 0,0027 & 0,0194 & - \\
Quantidade de espuma total & 27,16 & - & 27,16 \\
Massa de 50 espumas encharcadas (g) & 10.211 & 50 & - \\
Massa de 1 espuma encharcada (g) & - & 40,0031 & - \\
Massa total de espumas encharcadas (g) & - & 0,800 & - \\
Densidade da espuma $\left(\mathrm{g} . \mathrm{cm}^{-3}\right)$ & 1420,69 & - & - \\
Massa especifica da água a $25^{\circ} \mathrm{C}\left(\mathrm{g} . \mathrm{cm}^{-3}\right)$ & - & 0,023 & 0,023 \\
Volume da espuma $\left(\mathrm{cm}^{3}\right)$ & 0,997 & 0,997 & - \\
Volume de vazios $\left(\mathrm{cm}^{3}\right)$ & - & 0,85 & 1180,87 \\
Volume do leito/total $\left(\mathrm{cm}^{3}\right)$ & 1397,72 & 0,78 & 433,11 \\
Porosidade & 1613,98 & - & 1613,98 \\
\hline
\end{tabular}

A Tabela 13 mostra os dados comparativos dos valores de porosidade e permeabilidade da coluna úmida de alguns autores.

TABELA 13 - Comparação dos dados obtidos de porosidade da espuma e permeabilidade do leito.

\begin{tabular}{ccc}
\hline Autor & Permeabilidade K $\left(\mathrm{cm}^{2}\right)$ & Porosidade $\left(\varepsilon_{\text {espuma }}\right)$ \\
\hline MOE \& IRVINE, 2000a & - & 0,85 \\
RODRIGUES, 2002a & $1,07 \mathrm{E}-5$ & - \\
MAIA, 2003 & $3,579 \mathrm{E}-6$ & 0,61 \\
Este trabalho & $9,17 \mathrm{E}-5$ & 0,87 \\
\hline
\end{tabular}

Mesmo com valores de permeabilidade diferentes dos encontrados por Rodrigues (2002a) e Maia (2003), a ordem de grandeza dos valores encontrados são as mesmas encontradas por Rodrigues (2002a).

O valor da porosidade obtido de 0,87 é bem próximo aos obtidos por Moe e Irvine (2000a) que obtiveram uma porosidade de 0,85 , mas discrepantes com os obtidos por Maia (2003) que obteve 0,61 . 
Na coluna úmida a vazão da corrente gasosa de 100 L.h ${ }^{-1}$, foi mantida sem umidificação durante dois dias, sendo realizado no sistema apenas a remoção do percolado para se verificar a existência de um gradiente e umidade ao longo do leito.

O perfil de umidade do biofiltro foi realizado subdividindo-se o biofiltro em sete secções, onde a secção 1 é a secção superior do biofiltro e a 7 a secção inferior e em cada uma das secções foi calculada a umidade e a porosidade, os valores obtidos são apresentados na Tabela 14.

TABELA 14 - Dados de umidade e porosidade do leito por secção

\begin{tabular}{cccccc}
\hline \multirow{2}{*}{ Secção } & $\begin{array}{c}\text { Altura da } \\
\text { Secção }(\mathrm{cm})\end{array}$ & $\begin{array}{c}\text { Massa Seca } \\
(\mathrm{g})\end{array}$ & $\begin{array}{c}\text { Massa } \\
\text { Úmida }(\mathrm{g})\end{array}$ & $\begin{array}{c}\text { Umidade } \\
(\%)\end{array}$ & Porosidade \\
\hline 1 & 12 & 3,953 & 61,159 & $94 \%$ & 0,33 \\
2 & 9 & 2,956 & 42,194 & $93 \%$ & 0,33 \\
3 & 12 & 4,198 & 54,419 & $92 \%$ & 0,28 \\
4 & 10 & 3,866 & 45,084 & $91 \%$ & 0,21 \\
5 & 9,5 & 3,790 & 43,323 & $91 \%$ & 0,18 \\
6 & 11,5 & 4,701 & 51,431 & $91 \%$ & 0,16 \\
7 & 12 & 3,695 & 47,623 & $92 \%$ & 0,37 \\
Média & 10,86 & 3,88 & 49,319 & $92 \%$ & 0,27 \\
\hline
\end{tabular}

Com os resultados obtidos se observou que não ocorreram estratificações no leito quanto à umidade ao longo da coluna, pois mesmo durante dois dias sem a recirculação do percolado não ocorreu estratificação da umidade na coluna e todas as secções mantiveram uma umidade do leito acima de $90 \%$, sendo assim, durante a operação do sistema não ocorreram problemas de umidificação no leito.

Os dados de perda de carga obtidos neste trabalho vão de $0,18.10^{-2}$ mca para a espuma de poliuretano seca e uma velocidade superficial de ar de $0,40 \mathrm{~cm} / \mathrm{s}$ a $1,21.10^{-2}$ mca para a espuma de poliuretano após 121 dias de operação do sistema com uma velocidade superficial de ar de 1,96 cm/s, estando de acordo com os valores de perda de carga citados em literatura por Moe e Irvine (2000a), Rodrigues (2002a) e Maia (2003), podem variar de $0,14.10^{-2}$ a $1,53.10^{-2}$ mca.

Morgan-Sagastume e Noyola (2006) estudando um leito de composto, encontrou perdas de carga que variaram de $4,5.10^{-2}$ mca para as partículas secas e quando era adicionado água no sistema a perda de carga subia para $9,3 \cdot 10^{-2}$ mca para uma velocidade superficial de $2,06 \mathrm{~cm} \cdot \mathrm{s}^{-1}$. 
A Tabela15 mostra os resultados obtidos por diferentes pesquisadores referentes a perdas de carga.

TABELA 15 - Comparação dos resultados perda de carga da literatura com os deste trabalho

\begin{tabular}{|c|c|c|c|c|}
\hline Autor & Suporte & $\Delta \mathrm{P}\left(10^{-2} \mathrm{mca}\right)$ & $\begin{array}{l}\text { Velocidade } \\
\left(\mathrm{cm} \cdot \mathrm{s}^{-1}\right)\end{array}$ & Umidade (\%) \\
\hline $\begin{array}{l}\text { CARLSON \& } \\
\text { LEISER, } 1966 \\
\text { VAN }\end{array}$ & $\begin{array}{c}\text { Solo Argiloso } \\
\phi=\text { Não cita } \\
\text { Lascas de }\end{array}$ & 7,5 & 0,17 & Saturado \\
\hline $\begin{array}{l}\text { LANGENHOVE } \\
\text { et al. } 1986 .\end{array}$ & $\begin{array}{c}\text { madeira } \phi: 58,2 \\
\%>4,75 \mathrm{~mm}\end{array}$ & 0,71 & 8,3 & 73 \\
\hline $\begin{array}{c}\text { MORAES } \\
\text { JÚNIOR, } 1991\end{array}$ & Solo, $\phi<2 \mathrm{~mm}$ & $66-119$ & $0-0,16$ & Até 20 \\
\hline $\begin{array}{c}\text { YANG \& } \\
\text { ALLEN, } 1994\end{array}$ & $\begin{array}{c}\text { Composto } \phi< \\
1,2 \mathrm{~mm}\end{array}$ & Até 347 & $2-28$ & 50 \\
\hline $\begin{array}{c}\text { WEBSTER et al. } \\
1996\end{array}$ & $\begin{array}{c}\text { Carvão ativado } \\
\text { e Composto } \phi= \\
\text { Não cita }\end{array}$ & $\begin{array}{c}\text { Carvão ativado } \\
=0,92 \\
\text { Composto }= \\
1,73\end{array}$ & $\begin{array}{l}\text { Carvão ativado } \\
=1,5 \text { Composto } \\
=1,5\end{array}$ & $\begin{array}{c}\text { Carvão ativado } \\
=41,9 \\
\text { Composto }= \\
67,9\end{array}$ \\
\hline WU et al. 1999 & $\begin{array}{c}\text { Turfa }+ \text { agentes } \\
\phi=10 \mathrm{~mm}\end{array}$ & 3 & 2 & Não cita \\
\hline $\begin{array}{c}\text { RODRIGUES, } \\
2002 \mathrm{a}\end{array}$ & $\begin{array}{c}\text { Solo } \phi=0,5 \\
\text { mm Espuma de } \\
\text { poliuretano, } \\
\text { cubos de } 5 \mathrm{~mm}\end{array}$ & $\begin{array}{c}\text { Solo }=58-98 \\
\text { Espuma }=0,14 \\
-0,98\end{array}$ & $0,71-2,27$ & $12-24$ \\
\hline MAIA, 2003 & $\begin{array}{l}\text { Espuma de } \\
\text { poliuretano, } \\
\text { cubos de } 5 \mathrm{~mm} \\
\text { Esnuma de }\end{array}$ & 0,66 & 1,40 & Não cita \\
\hline Este trabalho & $\begin{array}{l}\text { Espuma de } \\
\text { poliuretano, } \\
\text { cubos de } 5 \mathrm{~mm}\end{array}$ & 0,54 & 1,31 & 92 \\
\hline
\end{tabular}

Morgan-Sagastume et al. (2001) trabalhando com lascas de madeira notou que após 30 dias de operação começou a ocorrer um aumento na perda de carga, pelo acúmulo de umidade nas lascas de madeira, a solução para isso foi o revolvimento do leito em determinados intervalos de tempo. Isso fazia com que a perda de carga caísse a praticamente o valor inicial.

Van Langehove et al. (1986) utilizando biofiltros com meio suporte de lascas de madeira fizeram uma relação entre a perda de carga no sistema e a umidade, nessa relação os autores constataram que perdas de carga na ordem de $1000 \mathrm{~Pa}(10,21 \mathrm{~cm}$ de Ca) estava associada a umidades da ordem de 78-80\% e para perdas de carga da ordem de $350 \mathrm{~Pa}$ $(3,58 \mathrm{~cm}$ de $\mathrm{Ca})$ a umidade estava entre $60-65 \%$, enquanto perdas inferiores a $350 \mathrm{~Pa}$ estão 
associadas com uma umidade inferior a 55\%. Nesse mesmo estudo os autores relacionaram a perda de carga no sistema com a eficiência, constando que a eficiência no sistema cai drasticamente quando a perda de carga no sistema cai abaixo de $200 \mathrm{~Pa}(2,04 \mathrm{~cm}$ de Ca), mas para perdas entre 350 e $1000 \mathrm{~Pa}$ as eficiências não são significativamente aumentadas, ficando na ordem de $95 \%$.

Como um aumento da perda de carga aumenta os custos de operação do sistema, é necessário encontrar o ponto de equilíbrio em que o sistema tenha a melhor eficiência com a menor perda de carga e uma umidade que seja suficiente para o crescimento e manutenção dos microrganismos. Sendo assim a espuma de poliuretano se mostrou com relação à perda de carga e a umidade do leito um ótimo meio suporte, pois o leito apresentou umidade da ordem de $92 \%$ com perdas de carga abaixo de $0,8.10^{-2}$ mca.

\subsection{Adsorção do $\mathrm{H}_{2} \mathrm{~S}$}

A concentração de sulfeto média utilizada na entrada da coluna nesse ensaio foi de aproximadamente $270 \mathrm{ppm}$, que foi a concentração media utilizada em uma das primeiras fases de operação do sistema, o ensaio teve uma duração de 50 horas.

A Tabela 16 mostra os dados obtidos no ensaio de adsorção (concentração de entrada $\left(\mathrm{C}_{\mathrm{e}\left(\mathrm{H}_{2} \mathrm{~S}\right)}\right)$ e concentração de saída $\left.\left(\mathrm{C}_{\mathrm{s}\left(\mathrm{H}_{2} \mathrm{~S}\right)}\right)\right)$ assim como a freqüência das análises realizadas.

TABELA 16 - Dados obtidos no ensaio de adsorção.

\begin{tabular}{ccccc}
\hline Tempo $(\mathrm{h})$ & \multicolumn{2}{c}{$\mathrm{C}_{\mathrm{e}(\mathrm{H} 2 \mathrm{~S})}(\mathrm{ppm})$} & $\mathrm{C}_{\mathrm{s}(\mathrm{H} 2 \mathrm{~S})}(\mathrm{ppm})$ \\
\hline 0,17 & 237 & 237 & 209 & 217 \\
1 & 254 & 254 & 283 & 286 \\
2 & 274 & 267 & 276 & 271 \\
4 & 248 & 248 & 262 & 267 \\
6 & 248 & 248 & 232 & 240 \\
8 & 223 & 228 & 224 & 214 \\
10 & 315 & 315 & 278 & 283 \\
18 & 409 & 401 & 408 & 404 \\
20 & 321 & 324 & 317 & 326 \\
22 & 296 & 296 & 282 & 276 \\
24 & 268 & 272 & 262 & 270 \\
26 & 243 & 243 & 257 & 265 \\
28 & 243 & 243 & 229 & 235 \\
30 & 219 & 214 & 229 & 224 \\
50 & 338 & 343 & 343 & 344 \\
\hline
\end{tabular}


As variações nas concentrações de entrada podem ser devido tanto às variações na pressão da corrente de ar, quanto na vazão de sulfeto que, por apresentar vazões muito baixas (cerca de 20 bolhas por minuto), uma pequena variação de 2 ou 3 bolhas por minuto provoca variações na concentração de aproximadamente 10\%, em ensaios preliminares após a estabilização da vazão notou-se que ao longo do dia a variação da vazão das bolhas variava em torno de 5 a 7 bolhas por minuto, com uma tendência em aumentar a concentração.

Na Figura 21 são apresentados os dados referentes ao teste de adsorção realizado na espuma de poliuretano seca.

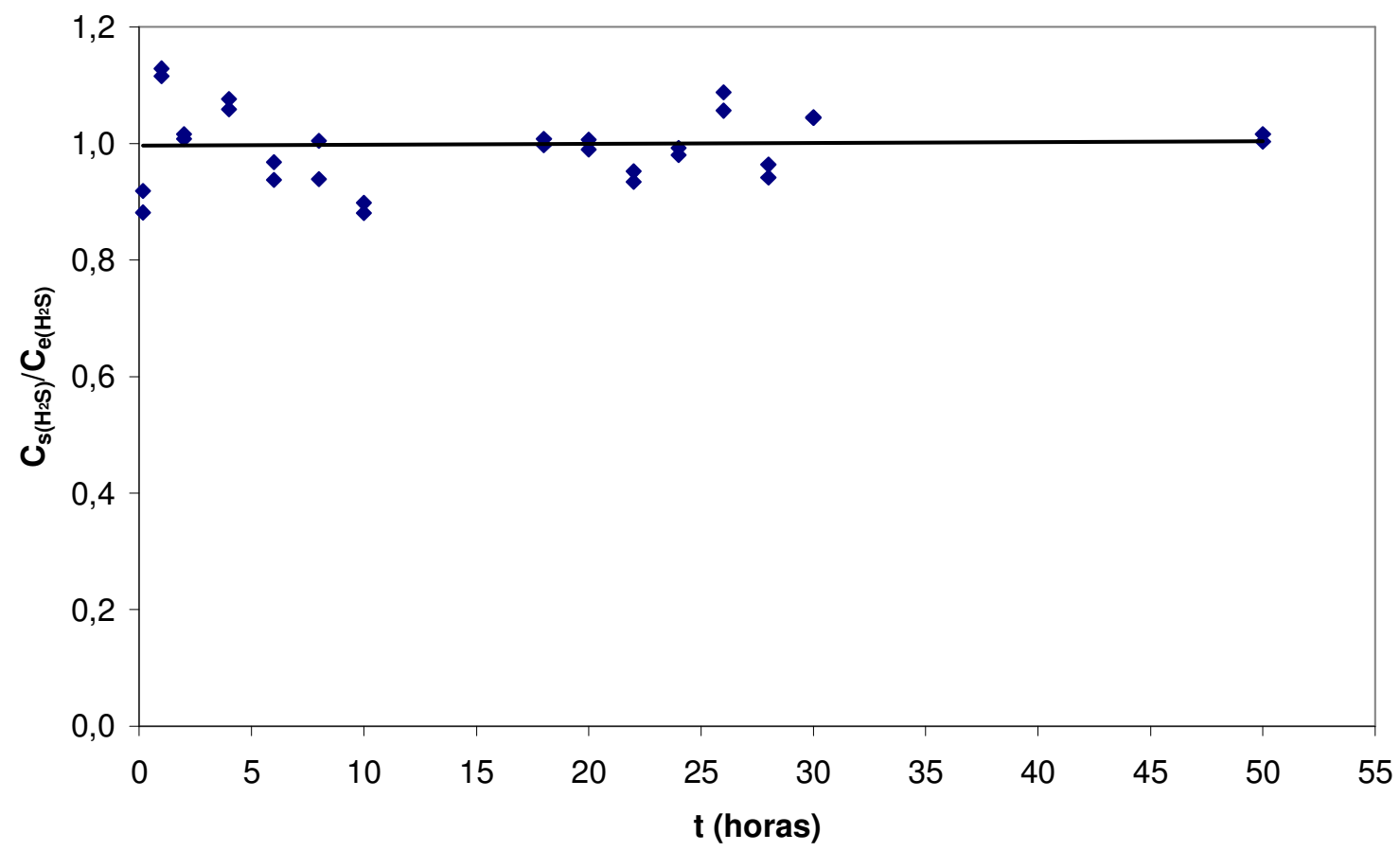

Figura 21. Curva de ruptura.

O gráfico de adsorção apresentado na Figura 21 juntamente com os gráficos apresentados por Moe e Irvine (2000a) na Figura 15 demonstra que a espuma de poliuretano por sua baixa capacidade adsorvente satura em alguns minutos, podendo-se afirmar que no caso de uma operação prolongada do sistema o efeito da adsorção não é um parâmetro relevante. 


\subsection{Biofiltração do $\mathbf{H}_{2} \mathrm{~S}$}

A operação do biofiltro foi realizada em sete fases com duração aproximada de 15 dias e as concentrações médias de entrada foram aumentadas progressivamente de 141 a 1303, como mostrado na Tabela 17.

TABELA 17 - Duração das fases do sistema, suas concentrações médias de entrada $\left(\mathbf{C}_{\mathrm{eH} 2 \mathrm{~S}}\right)$, saída $\left(\mathbf{C}_{\mathrm{sH} 2 \mathrm{~S}}\right)$ e eficiência.

\begin{tabular}{|c|c|c|c|c|c|}
\hline Fase & $\begin{array}{c}\text { Duração } \\
\text { (dias) }\end{array}$ & $\begin{array}{c}\text { Período } \\
\text { (dias) }\end{array}$ & $\begin{array}{c}\mathrm{C}_{\mathrm{eH} 2 \mathrm{~S}} \\
(\mathrm{ppm})\end{array}$ & $\begin{array}{c}\mathrm{C}_{\mathrm{sH} 2 \mathrm{~S}} \\
(\mathrm{ppm})\end{array}$ & $\begin{array}{c}\text { Eficiência } \\
(\%)\end{array}$ \\
\hline I & 20 & $1^{\circ}-20^{\circ}$ & 141 & 3 & 98 \\
\hline II & 14 & $21^{\mathrm{o}}-34^{\mathrm{o}}$ & 271 & 0 & 100 \\
\hline III & 9 & $35^{\circ}-43^{\circ}$ & 514 & 0 & 100 \\
\hline IV & 13 & $44^{\mathrm{o}}-56^{\mathrm{o}}$ & 532 & 141 & 74 \\
\hline V & 17 & $57^{\circ}-73^{\circ}$ & 581 & 0 & 100 \\
\hline VI & 21 & $74^{\circ}-94^{\circ}$ & 878 & 113 & 87 \\
\hline Paralisação & 14 & $95^{\circ}-108^{\circ}$ & - & - & - \\
\hline VII & 13 & $109^{\circ}-121^{\mathrm{o}}$ & 1303 & 20 & 98 \\
\hline
\end{tabular}

Com os dados da concentração de entrada foi calculada uma média dos pontos adicionando-se nessa média o desvio padrão, que é apresentado graficamente.

Um gráfico com todos os dados de concentração encontrados na operação do sistema é apresentado na Figura 22.

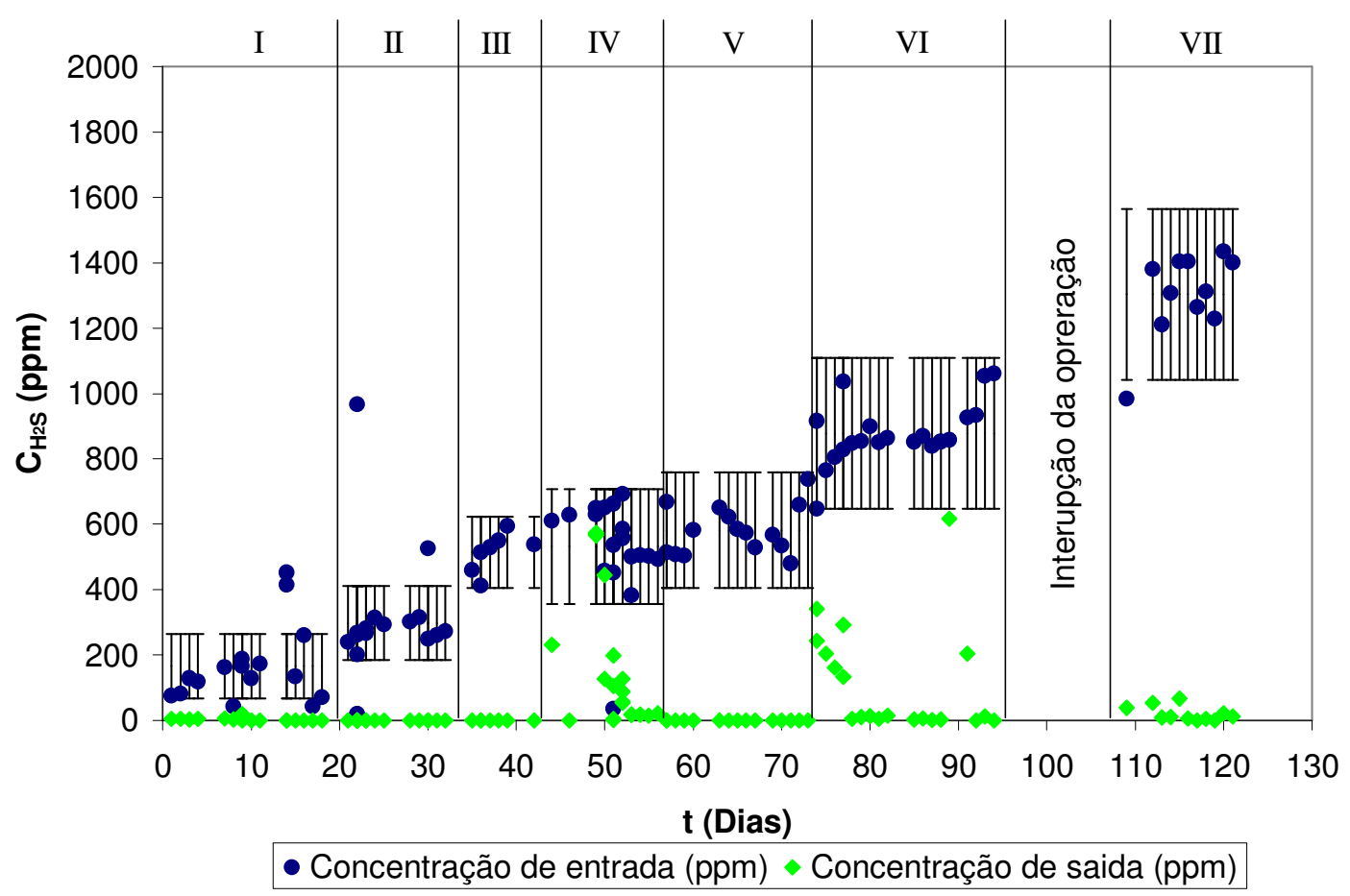

Figura 22. Valores de concentração de $\mathrm{H}_{2} \mathrm{~S}$ na entrada e saída do biofiltro durante a operação do sistema. 
A Figura 23 mostra as concentrações médias de entrada e saída e as eficiências médias obtidas durante a operação do biofiltro por fases.

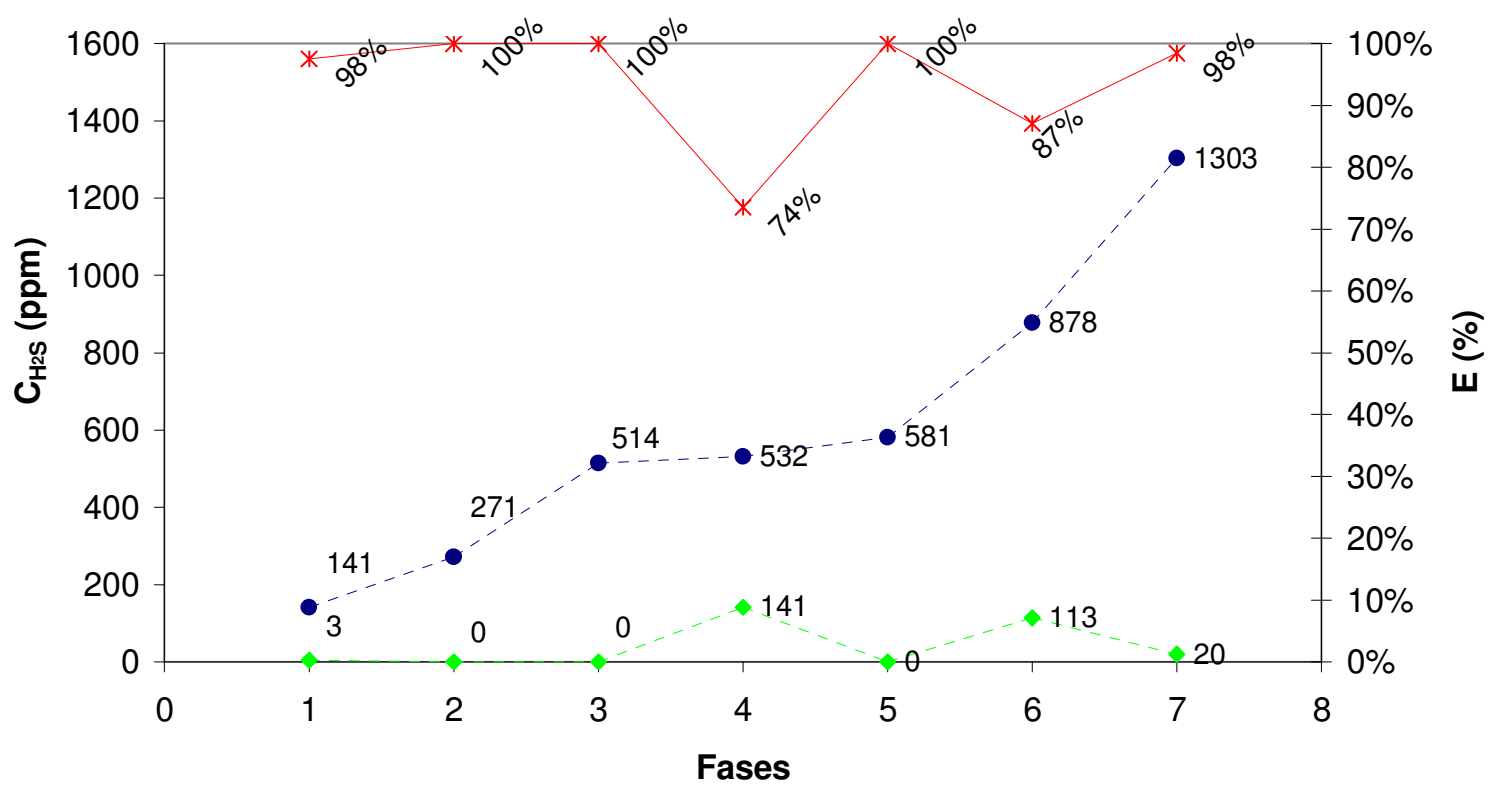

- - Concentração média de entrada (ppm) - - Concentração média de saida (ppm) — Eficiência

Figura 23. Valores médios de concentração na entrada e na saída nas 7 fases de operação do biofiltro.

$\mathrm{Na}$ figura 24 foram calculadas as eficiências de todos os pontos e os dados foram plotados no gráfico para uma melhor visualização da eficiência do biofiltro ao longo da operação. 


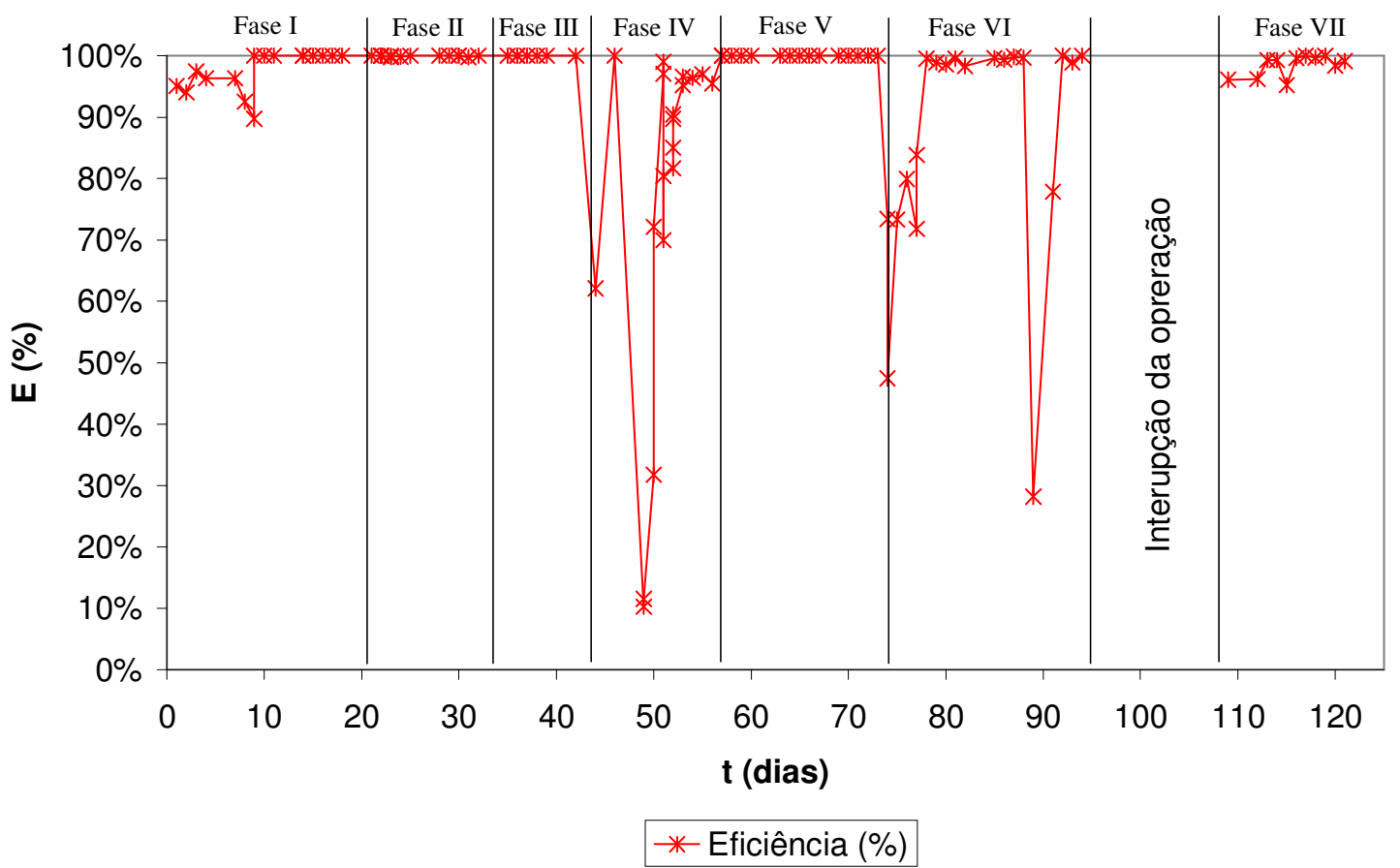

Figura 24. Eficiência de remoção do biofiltro

Para uma melhor análise dos dados as fases são mostradas separadamente nas figuras e tabelas a seguir.

O ensaio de biofiltração na primeira fase foi realizado operando-se o sistema por um período de 18 dias, e concentrações médias de $141 \mathrm{ppm}$ sendo monitoradas as concentrações de entrada e saída. Os valores de concentração medidos, tanto para a entrada quanto para a saída são apresentados na Tabela 18, assim como os respectivos valores das eficiências. 
TABELA 18 - Resultados obtidos na primeira fase de operação do sistema.

\begin{tabular}{ccccc}
\hline Fase & Tempo (dias) & $\mathrm{C}_{\mathrm{eH} 2 \mathrm{~S}}(\mathrm{ppm})$ & $\mathrm{C}_{\mathrm{sH} 2 \mathrm{~S}}(\mathrm{ppm})$ & Eficiência \\
\hline 1 & 76 & 4 & $95,0 \%$ \\
2 & 81 & 5 & $94,0 \%$ \\
3 & 129 & 3 & $97,5 \%$ \\
4 & 118 & 4 & $96,4 \%$ \\
7 & 163 & 6 & $96,4 \%$ \\
8 & 43 & 3 & $92,5 \%$ \\
9 & 189 & 19 & $89,7 \%$ \\
9 & 167 & 0 & $100,0 \%$ \\
10 & 130 & 0 & $100,0 \%$ \\
& 11 & 173 & 0 & $100,0 \%$ \\
& 14 & 453 & 0 & $100,0 \%$ \\
& 14 & 415 & 0 & $100,0 \%$ \\
& 15 & 0 & $100,0 \%$ \\
& 16 & 261 & 0 & $100,0 \%$ \\
& 17 & 0 & $100,0 \%$ \\
& 18 & 71 & 0 & $100,0 \%$ \\
\hline
\end{tabular}

Os dados obtidos mostraram que as concentrações de entrada sofreram oscilações, mas as concentrações de saída se mantiveram praticamente constantes, oscilando apenas nos primeiros dias na faixa 3 a 6 ppm e no dia 9 ocorrendo uma saída de 19 ppm, mas a partir do décimo dia de operação as concentrações de saída mantiveram-se em 0 ppm.

A Figura 25 mostra as concentrações de entrada, saída, eficiência e o desvio padrão das concentrações de entrada durante a operação do biofiltro na primeira fase.

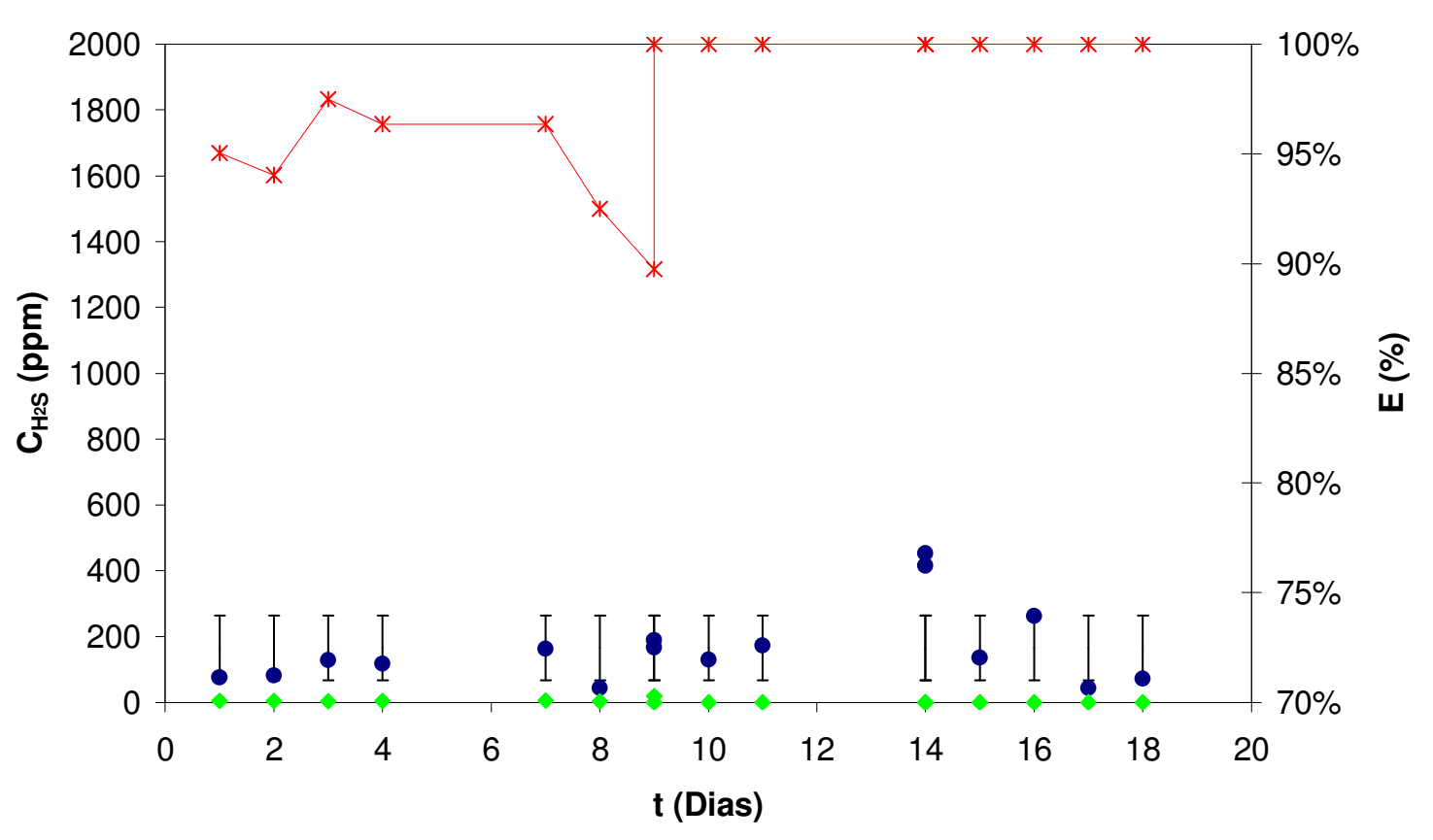

- Concentração de entrada (ppm) • Concentração de Saída (ppm) * Eficiência (\%)

Figura 25. Valores de Concentração de entrada, saída e eficiência do biofiltro na primeira fase 
Como mostrado no ensaio de adsorção (Tabela 16 e Figura 22) e como ilustrado por Moe e Irvine (2000a) (Figura 15) a capacidade de adsorção da espuma de poliuretano se esgota em poucos minutos, concluindo-se assim que a eficiência encontrada já no primeiro dia de operação (95\%) foi resultante exclusivamente da biodegradação, mostrando que mesmo no período de adaptação dos microrganismos ao sistema de biofiltração, esse processo já apresenta uma eficiência muito boa.

O período de adaptação do reator, levando-se em conta a fase em que se era possível detectar um residual de sulfeto na corrente gasosa de saída demorou cerca de 9 dias o que está muito próximo ao encontrado por Degorce-dumas et al. (1997) e Wada et al. (1986) que demorou cerca de 10 a 13 dias, trabalhando com turfa e lodo seco, Yang e Allen (1994), utilizando composto, Wani et al. (1999), utilizando composto e resíduos de jardinagem, Rodrigues (2002a) e Maia (2003), que testaram vários meios suportes, entre eles a espuma de poliuretano e trabalharam com culturas puras de Thiobacillus thioparus, também verificaram esse período de adaptação. Contrariamente Cho et al. (1992a), Cho et al. (1992b), Hartikainen et al. (2001) utilizando respectivamente turfa com Thiobacillus thioparus, Xantomonas sp. Thiobacillus TJ330 e Chung et al. (1996b) utilizando inoculação de Pseudomonas putida, observaram imediatamente eficiências de até $99 \%$.

Nessa primeira fase onde a concentração média ficou em torno de $141 \mathrm{ppm}$, e ocorreram variações nas concentrações de entrada observando-se concentrações de 42 ppm no $17^{\circ}$ dia e 453 ppm no $14^{\circ}$ dia, mas as eficiências de remoção se mantiveram acima de 92,5\% nos primeiros 8 dias e em $100 \%$ do $9^{\circ}$ dia em diante, de acordo com o encontrado por Morgan-sagastume e Noyola (2006) que trabalharam com composto maturado e ao contrario do encontrado por Chung et al. (1996a) trabalhando com Thiobacillus thioparus e alginato de cálcio, verificou que uma variação de 5 para 60 ppm reduzia a eficiência do reator em 8\% (de 98,5 para 90,5\%) e Chung et al. (1996b) trabalhando com Pseudomonas putida e alginato de cálcio, verificou que aumento de 20 para $200 \mathrm{ppm}$ fez com que a eficiência caísse de 97,5 para $64,5 \%$.

A média obtida nessa fase desconsidera as oscilações que ocorreram e que tem valores superiores a $400 \mathrm{ppm}$ e valores inferiores a $70 \mathrm{ppm}$ (provavelmente devido aos problemas operacionais já descritos anteriormente, como oscilações na vazão de bolhas, variação da pressão na corrente de ar e demora na resposta da válvula agulha) pois esses dados não são representativos para essa fase. 
Os dados obtidos na operação do biofiltro durante a segunda e terceira fase são mostrados na Tabela 19.

TABELA 19 - Resultados obtidos na segunda e terceira fases de operação do sistema.

\begin{tabular}{ccccc}
\hline Fase & Tempo (dias) & $\mathrm{C}_{\mathrm{eH} 2 \mathrm{~S}}(\mathrm{ppm})$ & $\mathrm{C}_{\mathrm{sH} 2 \mathrm{~S}}(\mathrm{ppm})$ & Eficiência \\
\hline 21 & 240 & 0 & $100,0 \%$ \\
22 & 19 & 0 & $100,0 \%$ \\
22 & 967 & 0 & $100,0 \%$ \\
22 & 19 & 0 & $100,0 \%$ \\
22 & 202 & 0 & $100,0 \%$ \\
& 22 & 262 & 0 & $100,0 \%$ \\
& 22 & 268 & 0 & $100,0 \%$ \\
II & 23 & 281 & 1 & $99,8 \%$ \\
& 23 & 315 & 0 & $100,0 \%$ \\
& 24 & 294 & 1 & $99,8 \%$ \\
& 25 & 302 & 0 & $100,0 \%$ \\
& 28 & 316 & 0 & $100,0 \%$ \\
& 29 & 526 & 0 & $100,0 \%$ \\
& 30 & 249 & 0 & $100,0 \%$ \\
& 30 & 261 & 1 & $100,0 \%$ \\
& 31 & 273 & 0 & $99,8 \%$ \\
& 32 & 459 & 0 & $100,0 \%$ \\
\hline \multirow{4}{*}{ III } & 35 & 412 & 0 & $100,0 \%$ \\
& 36 & 514 & 0 & $100,0 \%$ \\
& 36 & 530 & 0 & $100,0 \%$ \\
& 37 & 550 & 0 & $100,0 \%$ \\
& 38 & 594 & 0 & $100,0 \%$ \\
& 39 & 538 & 0 & $100,0 \%$ \\
& 42 & Rompimento da coluna central do biofiltro \\
\hline
\end{tabular}

Os dados da segunda fase mostraram que as concentrações de entrada também não sofreram muitas e grandes oscilações como na primeira fase, com exceção das ocorridas no dia 22 (19, 967 e 19 ppm) e no dia 30 (526 ppm), que foram desconsiderados no cálculo da média por não serem representativos para a fase.

A Figura 26 mostra as concentrações de entrada, saída, eficiência e o desvio padrão das concentrações de entrada durante a operação do biofiltro na segunda e na terceira fase. 


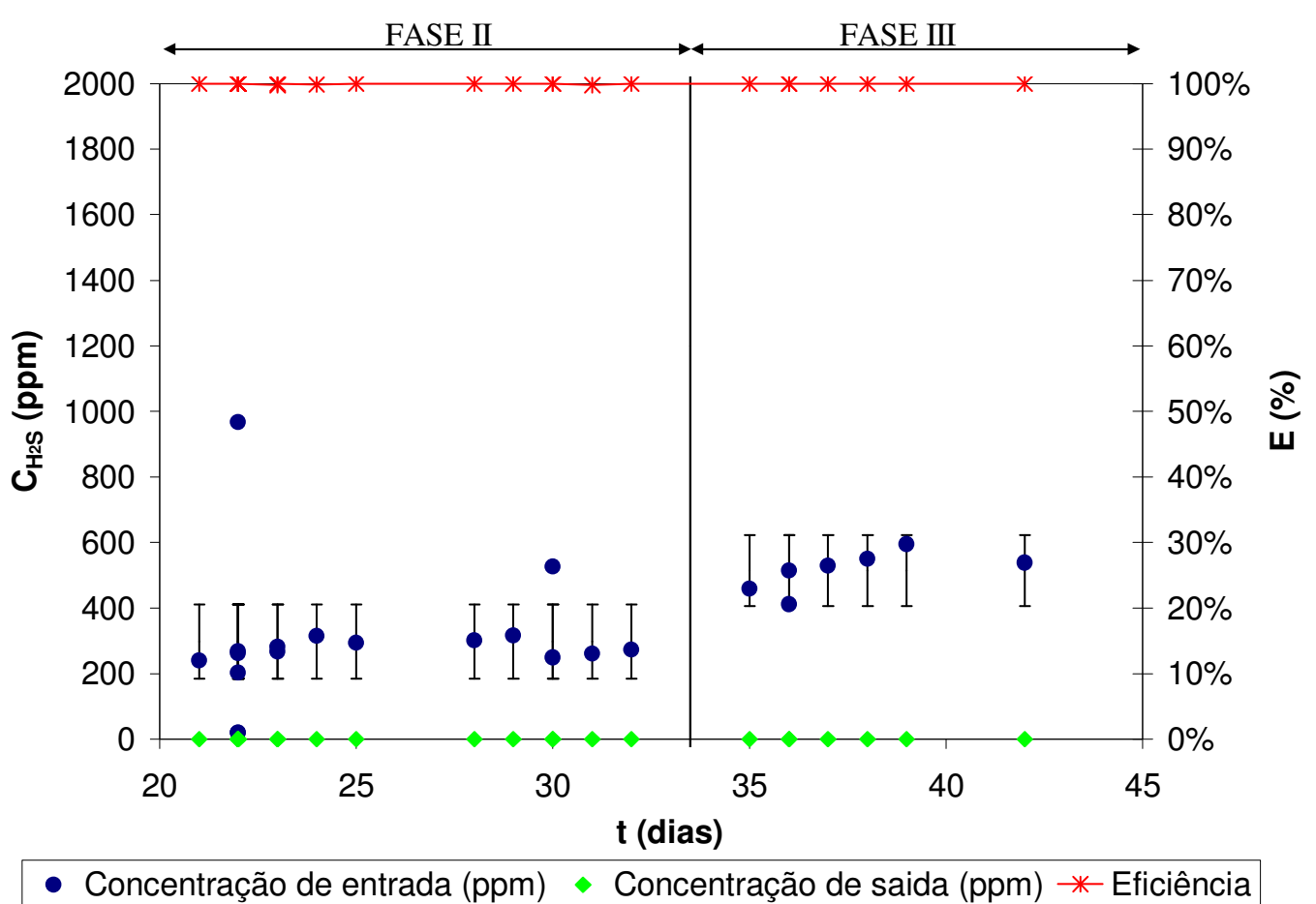

Figura 26. Valores de concentração de entrada, saída e eficiência do biofiltro na segunda fase.

Mesmo com a oscilação na concentração de entrada as concentrações de saída se mantiveram constantes Li et al. (1998) trabalhando com fibra plástica e lodo ativado e Morgan-sagastume e Noyola (2006) trabalhando com composto também verificaram oscilações nas concentrações de entrada e da mesma forma observaram que o sistema absorveu a sobrecarga de sulfeto, concluindo assim que o sistema de biofiltração em seus primeiros de operação tem uma alta capacidade em absorver uma sobrecarga de $\mathrm{H}_{2} \mathrm{~S}$.

Na segunda fase a concentração média de entrada foi de 271 ppm e a eficiência de remoção 100\%, esses valores são equivalentes aos encontrados por Oyarzún et al. (2003) utilizando turfa e Thiobacillus thioparus atingiu cerca de 355 ppm com eficiências de $100 \%$ e Wani et al. (1999) que utilizaram turfa, mas sem a queda de eficiência que Wani et al. (1999) relatou para concentrações acima de $250 \mathrm{ppm}$.

Os dados da terceira fase mostram que mesmo com uma concentração de entrada superior a das fases anteriores, a eficiência do sistema manteve-se em 100\%.

No $43^{\circ}$ dia de operação do sistema ocorreu o rompimento da coluna central do biofiltro, fazendo com que a operação do sistema fosse interrompida para a substituição da coluna por uma reserva, ao término da montagem do sistema reserva o leito foi transferido para a nova coluna. Após alguns minutos de operação com a coluna reserva, ocorreu 
novamente a quebra da coluna central, fazendo com que a operação do sistema fosse interrompida até o dia seguinte pela manhã, durante esse período a espuma foi transferida para um barrilete de $10 \mathrm{~L}$ contendo $5 \mathrm{~L}$ de solução nutriente ATCC 290 S6 sem o tiossulfato no qual manteve-se passando a corrente gasosa com o $\mathrm{H}_{2} \mathrm{~S}$.

A Tabela 20 mostra os valores obtidos na operação do biofiltro durante a quarta fase.

TABELA 20 - Resultados obtidos na quarta fase de operação do sistema.

\begin{tabular}{ccccc}
\hline Fase & Tempo (dias) & $\mathrm{C}_{\mathrm{eH} 2 \mathrm{~S}}(\mathrm{ppm})$ & $\mathrm{C}_{\mathrm{sH} 2 \mathrm{~S}}(\mathrm{ppm})$ & Eficiência \\
\hline 44 & 612 & 232 & $62,1 \%$ \\
46 & 629 & 0 & $100,0 \%$ \\
49 & 630 & 566 & $10,2 \%$ \\
49 & 649 & 574 & $11,5 \%$ \\
50 & 651 & 444 & $31,7 \%$ \\
50 & 459 & 128 & $72,1 \%$ \\
51 & 36 & 1 & $97,0 \%$ \\
$\mathrm{IV}$ & 453 & 4 & $99,1 \%$ \\
& 51 & 663 & 199 & $70,0 \%$ \\
& 51 & 536 & 105 & $80,4 \%$ \\
& 52 & 692 & 127 & $81,7 \%$ \\
& 52 & 586 & 88 & $85,1 \%$ \\
& 52 & 557 & 53 & $90,4 \%$ \\
& 52 & 560 & 58 & $89,7 \%$ \\
& 53 & 382 & 18 & $95,2 \%$ \\
& 53 & 502 & 17 & $96,6 \%$ \\
& 54 & 505 & 18 & $96,4 \%$ \\
& 55 & 503 & 15 & $97,0 \%$ \\
& 56 & 494 & 23 & $95,4 \%$ \\
\hline
\end{tabular}

A Figura 27 mostra as concentrações de entrada e saída durante a operação do reator na quarta fase. 


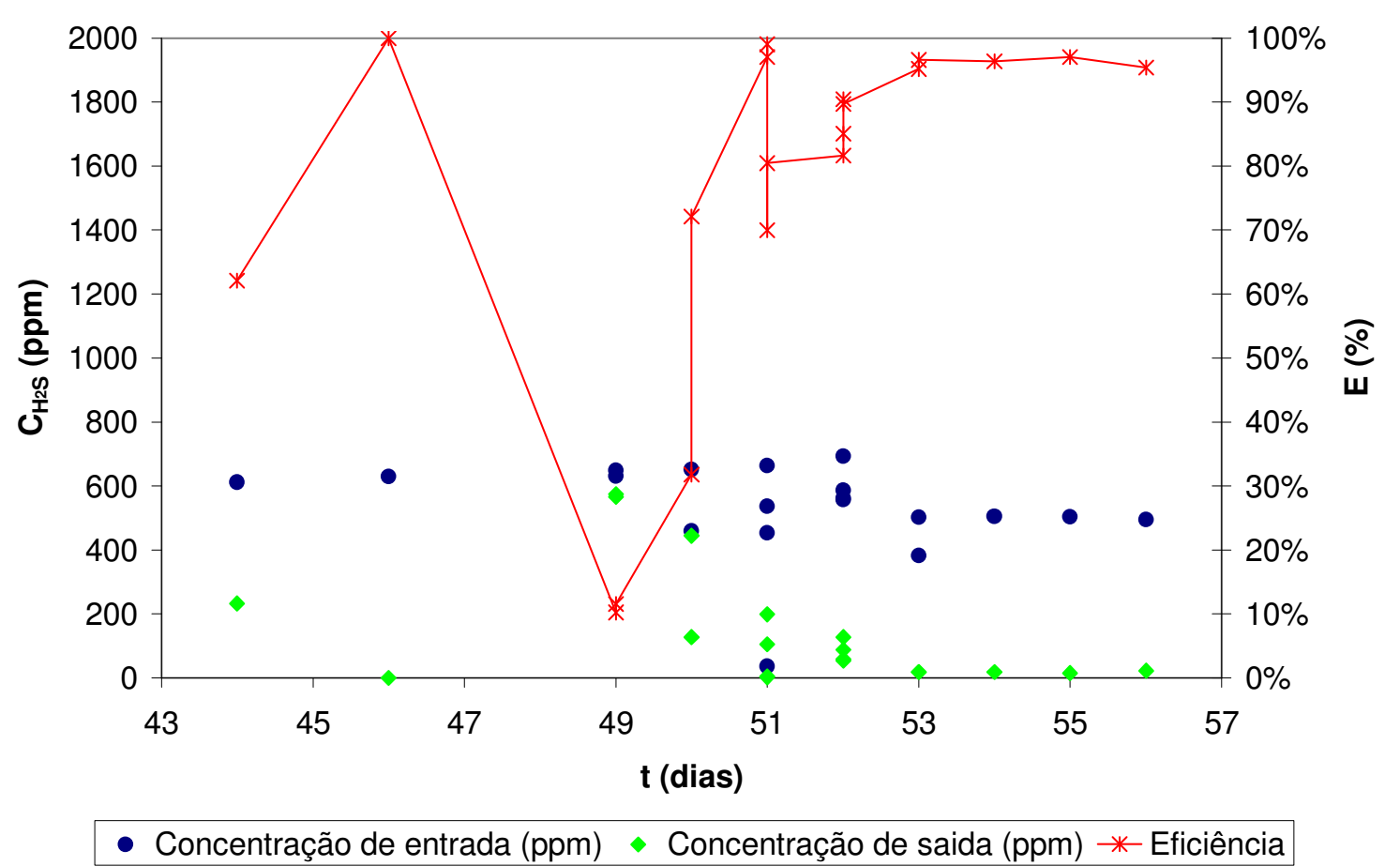

Figura 27. Valores de concentração de entrada e saída do biofiltro na quarta fase.

Com a perturbação sofrida o sistema no $44^{\circ}$ dia sofreu uma queda na eficiência de 100 para $62 \%$ (6 horas após o reinício do sistema), mas a eficiência foi rapidamente recuperada após dois dias ( $\left.46^{\circ} \mathrm{dia}\right)$.

No $46^{\circ}$ dia, por volta de 4 horas após ter sido realizada a análise das concentrações, ocorreu pela terceira vez a quebra da coluna central, novamente o material suporte foi colocado em solução nutriente até a confecção de uma nova coluna, o que levou cerca de três dias. No $49^{\circ}$ dia ao colocar-se novamente o sistema em operação foram medidas duas vezes as concentrações de entrada e saída, a primeira foi medida uma hora após a partida do sistema e a outra foi medida após seis horas.

As seguidas perturbações do sistema fizeram com que a eficiência caísse para cerca de $10 \%$ logo após o reinício, sendo rapidamente recuperada para cerca de $72 \%$ em menos de 24 horas e atingindo valores na ordem de $99 \%$ em torno de 48 horas.

Do $53^{\circ}$ ao $56^{\circ}$ dia ocorreram oscilações nas eficiências do sistema, mas mantendose uma eficiência média superior a $95 \%$.

A Tabela 21 mostra os valores obtidos na operação do biofiltro durante a quinta fase. 
TABELA 21 - Resultados obtidos na quinta fase de operação do sistema.

\begin{tabular}{ccccc}
\hline Fase & Tempo (dias) & $\mathrm{C}_{\mathrm{eH} 2 \mathrm{~S}}(\mathrm{ppm})$ & $\mathrm{C}_{\mathrm{sH} 2 \mathrm{~S}}(\mathrm{ppm})$ & Eficiência \\
\hline 57 & 669 & 0 & $100,0 \%$ \\
57 & 515 & 0 & $100,0 \%$ \\
58 & 509 & 0 & $100,0 \%$ \\
59 & 503 & 0 & $100,0 \%$ \\
$\mathrm{~V}$ & 582 & 0 & $100,0 \%$ \\
& 63 & 651 & 0 & $100,0 \%$ \\
& 64 & 622 & 0 & $100,0 \%$ \\
& 65 & 585 & 0 & $100,0 \%$ \\
66 & 574 & 0 & $100,0 \%$ \\
& 67 & 529 & 0 & $100,0 \%$ \\
69 & 567 & 0 & $100,0 \%$ \\
& 70 & 536 & 0 & $100,0 \%$ \\
& 41 & 080 & 0 & $100,0 \%$ \\
& 72 & 660 & 0 & $100,0 \%$ \\
& 73 & 0 & $100,0 \%$ \\
\hline
\end{tabular}

A Figura 28 mostra as concentrações de entrada, saída, eficiência e o desvio padrão das concentrações de entrada durante a operação do biofiltro na quinta fase.

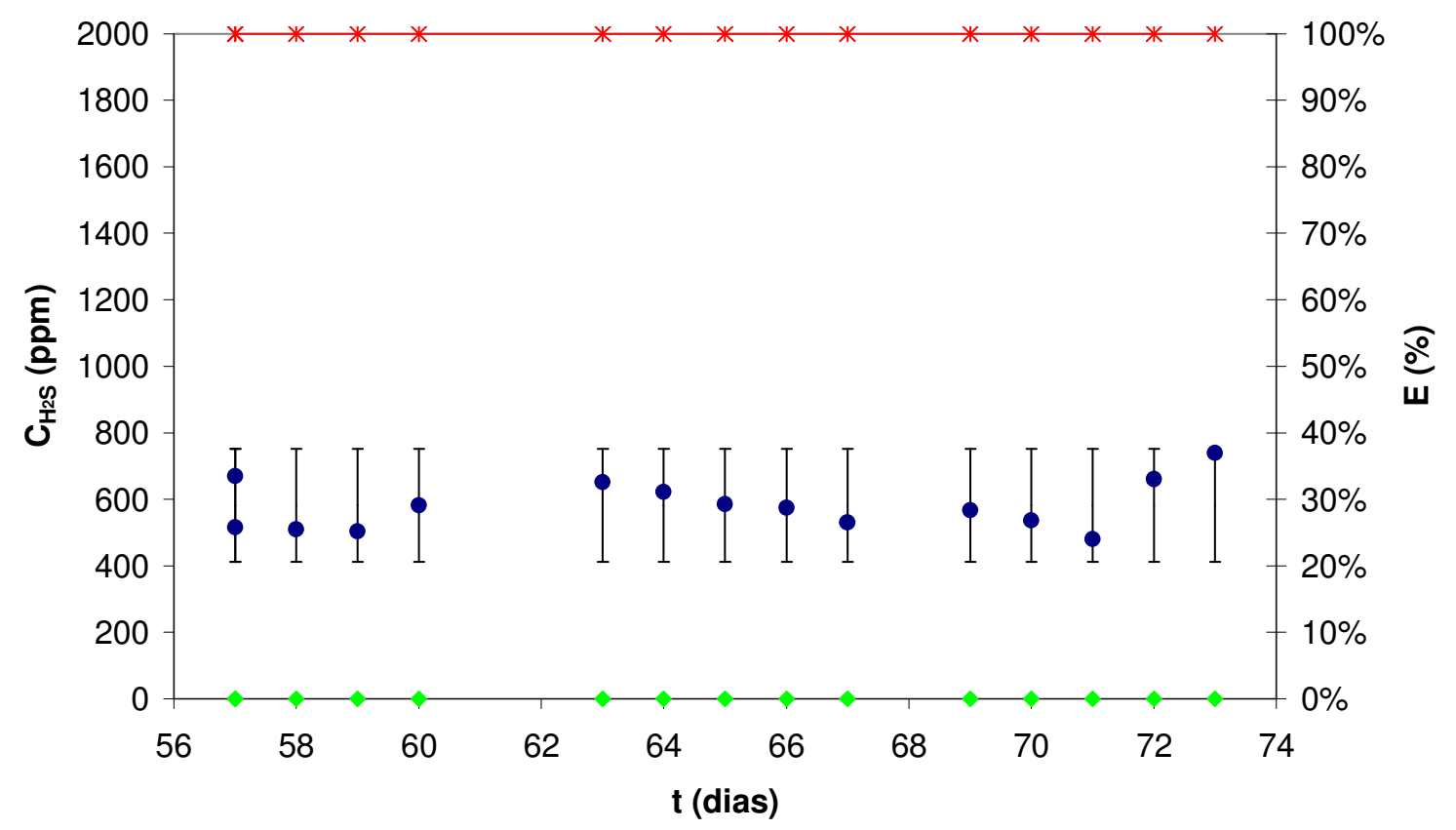

- Concentração de entrada (ppm) • Concentração de saida (ppm) * Eficiência

Figura 28. Valores de concentração de entrada e saída do biofiltro na quinta fase.

$\mathrm{Na}$ quinta fase, após o sistema ter atingido novamente um equilíbrio as eficiências de remoção atingiram novamente $100 \%$, e assim se mantiveram até o final da fase. A concentração média da corrente gasosa afluente dessa fase foi de 563 ppm, o que está de 
acordo com o relatado por Park et al. (2002) onde estes autores utilizando Thiobacillus sp. imobilizados em alginato de cálcio trataram por volta de 600 ppm com $100 \%$ eficiência.

A terceira, quarta e quinta fases a principio eram uma única fase, mas como aconteceram os problemas de quebra do biofiltro (relatados anteriormente) durante a operação do sistema ela foi subdividida em três fases para melhor ilustrar a rápida capacidade de recuperação do sistema mostrando assim a grande versatilidade e robustez de um sistema de biofiltração quando submetido a perturbações durante a sua operação.

A Tabela 22 mostra os valores obtidos na operação do biofiltro durante a sexta fase.

TABELA 22 - Valores obtidos na operação do biofiltro durante a sexta fase.

\begin{tabular}{ccccc}
\hline Fase & Tempo (dias) & $\mathrm{C}_{\mathrm{eH} 2 \mathrm{~S}}(\mathrm{ppm})$ & $\mathrm{C}_{\mathrm{sH} 2 \mathrm{~S}}(\mathrm{ppm})$ & Eficiência \\
\hline 74 & 916 & 244 & $73,4 \%$ \\
74 & 648 & 340 & $47,5 \%$ \\
75 & 766 & 204 & $73,3 \%$ \\
76 & 805 & 161 & $80,0 \%$ \\
77 & 1036 & 292 & $71,8 \%$ \\
77 & 829 & 134 & $83,8 \%$ \\
& 78 & 848 & 4 & $99,5 \%$ \\
& 79 & 854 & 10 & $98,9 \%$ \\
& 90 & 13 & $98,6 \%$ \\
& 80 & 850 & 4 & $99,5 \%$ \\
& 81 & 865 & 15 & $98,3 \%$ \\
& 82 & 852 & 3 & $99,6 \%$ \\
& 85 & 871 & 6 & $99,4 \%$ \\
& 86 & 839 & 2 & $99,8 \%$ \\
& 87 & 853 & 616 & $99,7 \%$ \\
& 88 & 858 & 205 & $28,2 \%$ \\
& 89 & 926 & 0 & $77,9 \%$ \\
& 91 & 934 & 12 & $100,0 \%$ \\
& 92 & 1054 & 0 & $98,9 \%$ \\
& 93 & 1062 & & $100,0 \%$ \\
\hline
\end{tabular}

A Figura 29 mostra as concentrações de entrada, saída, eficiência e o desvio padrão das concentrações de entrada durante a operação do biofiltro na sexta fase. 


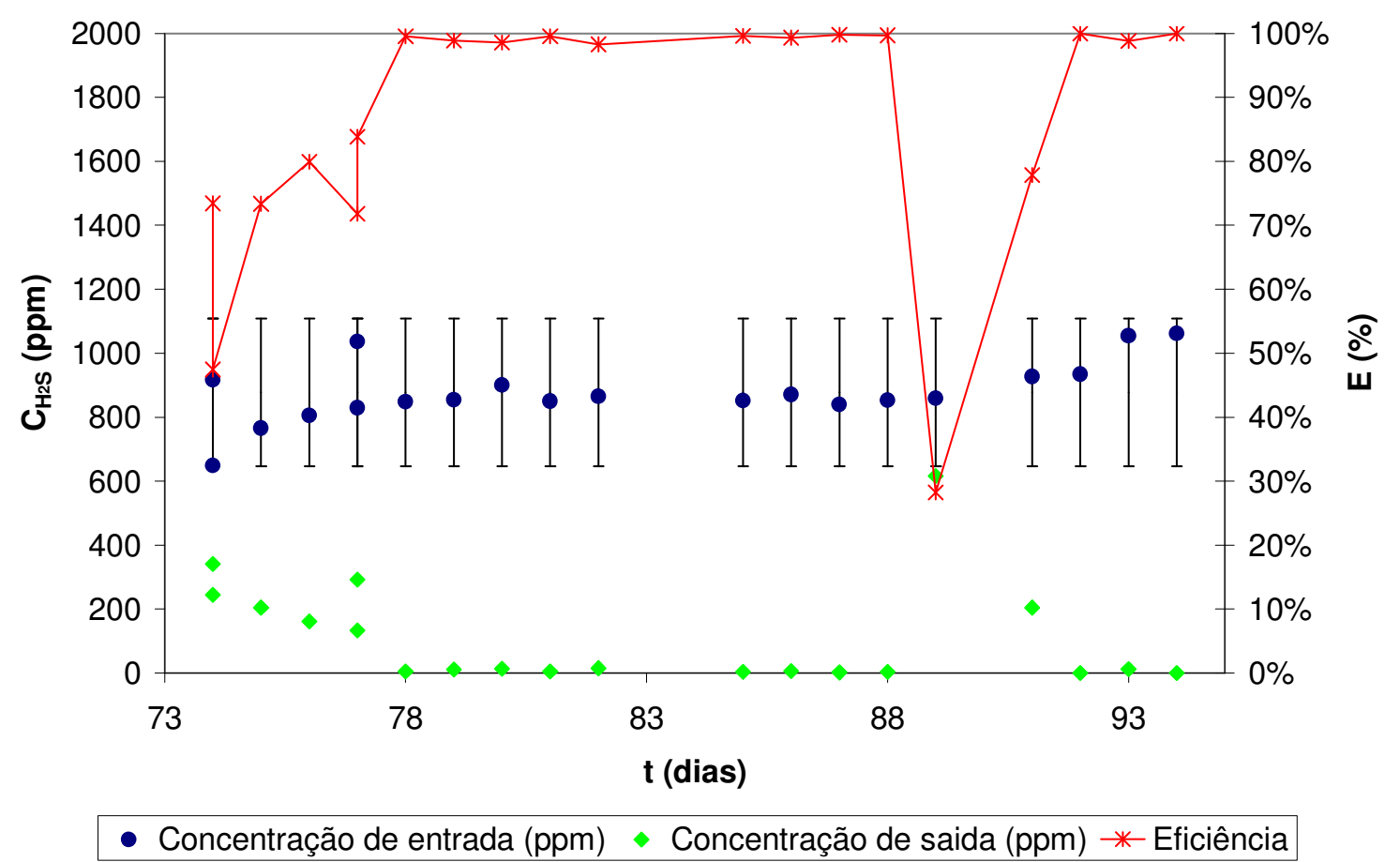

Figura 29. Valores de concentração de entrada e saída do biofiltro na sexta fase.

Com o aumento da concentração média de entrada da quinta para a sexta fase (571ppm para 878 ppm) a eficiência do sistema caiu nos primeiros dias, mas foi rapidamente recuperada, atingido eficiências acima de 98\%, similarmente do observado por Wani et al. (1998) que utilizaram como suporte uma mistura de composto, restos de jardinagem e perlita onde um aumento de 370 para 615 fez com que a eficiência caísse de 99,5 para 96\% sendo rapidamente recuperada e diferentemente do obtido por de Park et al. (2002) que utilizando Thiobacillus sp. imobilizados em alginato de cálcio o aumento na concentração de 600 para 1000 ppm com que ocorresse uma redução na eficiência mas esta não ultrapassou novamente os $80 \%$.

No $88^{\circ}$ dia após a medida da concentração, foi necessário interromper a alimentação do sistema, pois ocorreu um vazamento na linha de $\mathrm{H}_{2} \mathrm{~S}$ em virtude de um furo na mangueira que levava $\mathrm{o}_{2} \mathrm{~S}$ até o sistema. Com a volta da alimentação a eficiência do sistema caiu para $28 \%$, mas rapidamente o sistema se recuperou atingindo $100 \%$ no $92^{\circ}$ dia.

Para se avaliar o efeito de paralisações da alimentação do $\mathrm{H}_{2} \mathrm{~S}$ em um sistema foi feito a interrupção da alimentação do sulfeto na corrente gasosa por cerca e 15 dias, sendo adicionada normalmente a solução nutriente e esta era mantida em recirculação com o mesmo intervalo de tempo da operação do sistema (5 minutos a cada 6 horas). Decorrido 
os 15 dias foi realizada novamente a adição do $\mathrm{H}_{2} \mathrm{~S}$ na corrente gasosa nas concentrações referentes às da sétima fase.

A Tabela 23 mostra os valores obtidos na operação do biofiltro durante a sétima fase.

TABELA 23 - Valores obtidos na operação do biofiltro durante a sétima fase

\begin{tabular}{ccccc}
\hline Fase & Tempo (dias) & $\mathrm{C}_{\mathrm{eH} 2 \mathrm{~S}}(\mathrm{ppm})$ & $\mathrm{C}_{\mathrm{sH} 2 \mathrm{~S}}(\mathrm{ppm})$ & Eficiência \\
\hline & 109 & 984 & 39 & $96,1 \%$ \\
& 112 & 1380 & 53 & $96,2 \%$ \\
& 113 & 1211 & 9 & $99,3 \%$ \\
\multirow{3}{*}{ VII } & 114 & 1307 & 10 & $99,3 \%$ \\
& 115 & 1404 & 67 & $95,2 \%$ \\
& 116 & 1404 & 5 & $99,6 \%$ \\
& 117 & 1264 & 0 & $100,0 \%$ \\
& 118 & 1312 & 4 & $99,7 \%$ \\
& 119 & 1230 & 0 & $100,0 \%$ \\
& 120 & 1435 & 23 & $98,4 \%$ \\
& 121 & 1402 & 12 & $99,2 \%$ \\
\hline
\end{tabular}

A Figura 30 mostra as concentrações de entrada, saída, eficiência e o desvio padrão das concentrações de entrada durante a operação do biofiltro na sétima fase.

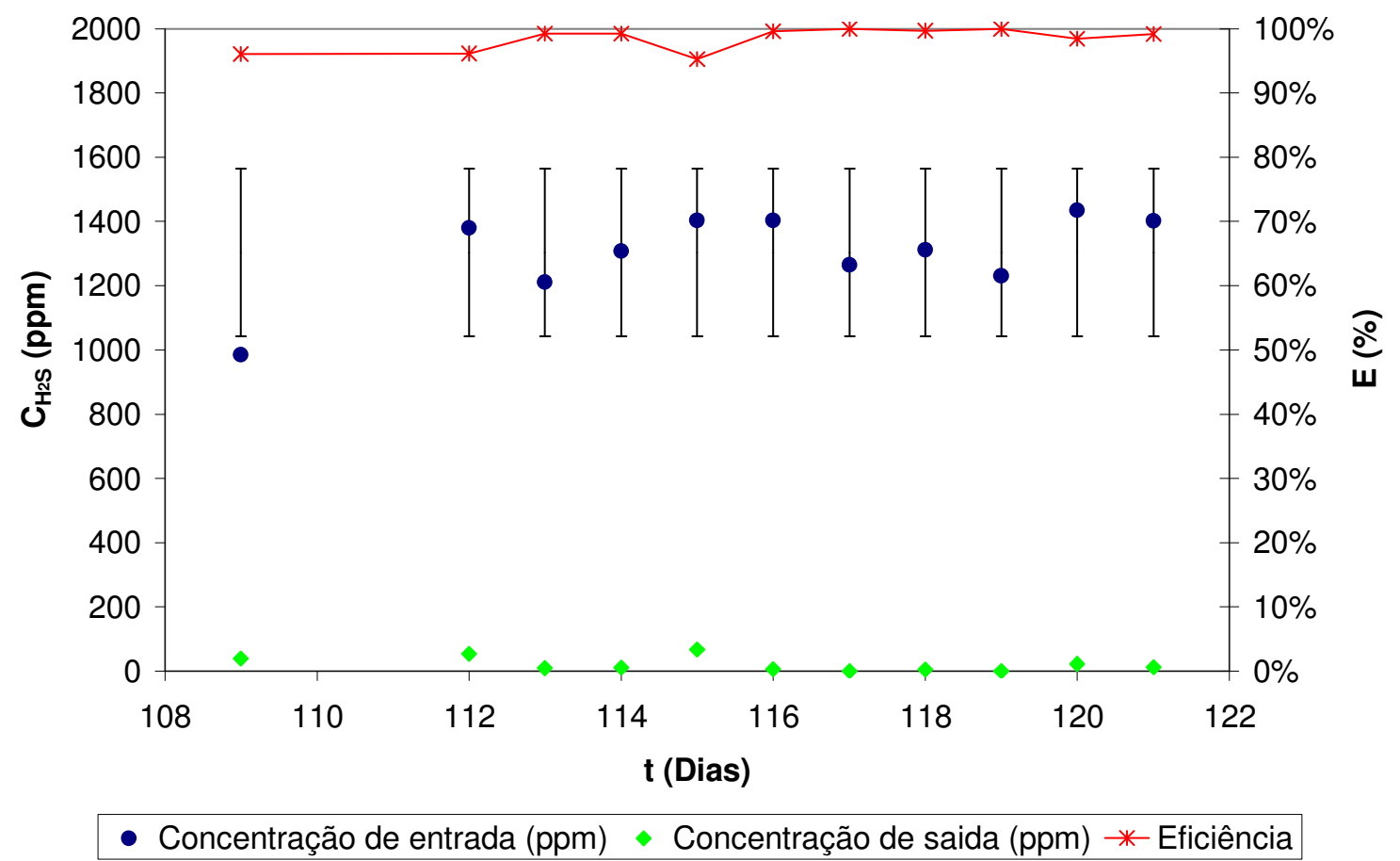

Figura 30. Concentrações de entrada e saída do biofiltro na sétima fase.

A paralisação e reinicio do sistema com uma carga superior a adicionada anteriormente não afetou significativamente a eficiência do sistema pois o aumento da 
concentração de entrada da quinta para a sexta fase resultou em um efeito mais relevante que o aumento da concentração da sexta para a sétima fase. As oscilações da eficiência ocorridas nessa fase são equivalentes as encontradas por Easter et al. (2005) que operaram o biofiltro em concentrações de 0,5 a 1350 ppm e vários meios suportes, obtiveram eficiências que variaram entre 96 e 99\% e Wani et al. (1998) que paralisou o biofiltro com uma mistura de composto, restos de jardinagem e perlita como meio suporte durante 7 dias e trabalhando novamente em concentrações de 340 ppm obteve após algumas horas eficiências de $99 \%$.

Na figura 31 são apresentados os valores de $\mathrm{pH}$ do percolado medidos durante a operação do biofiltro

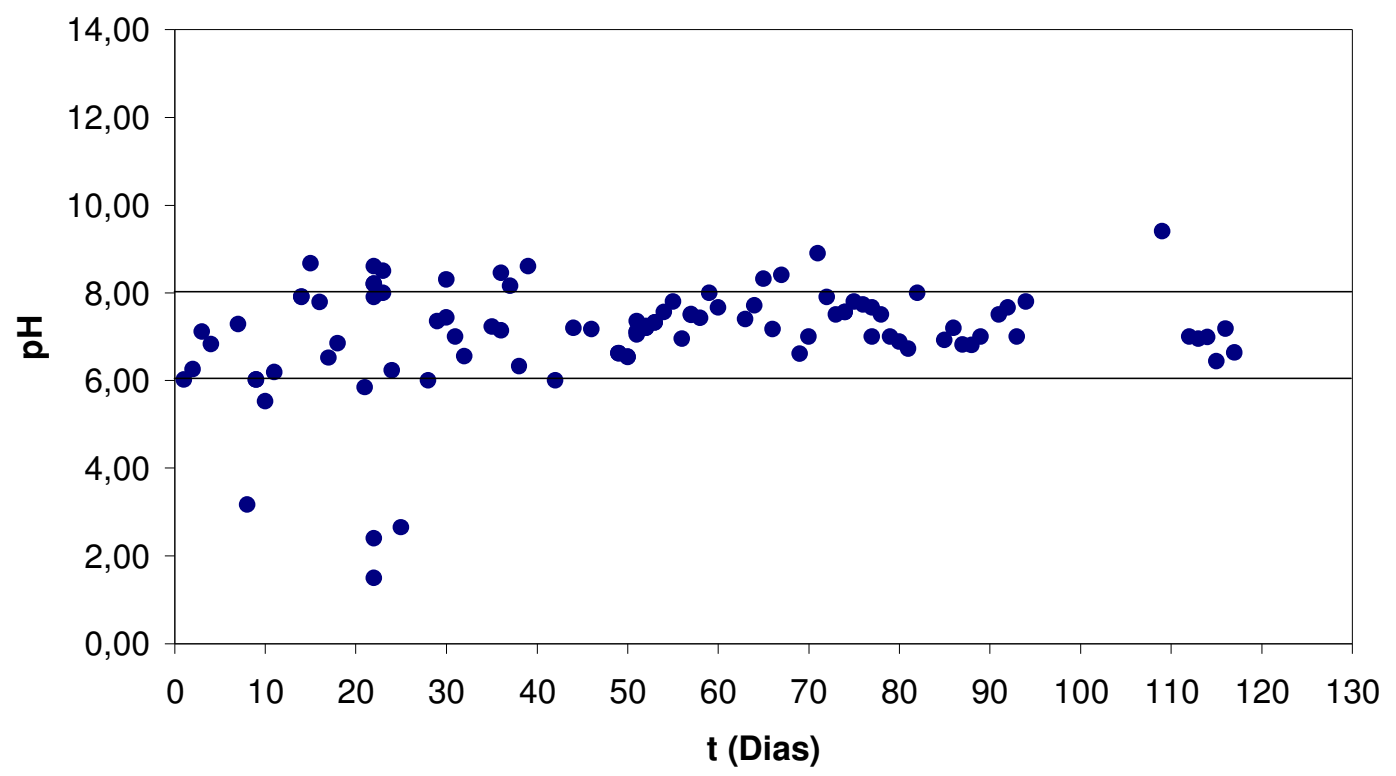

Figura 31. Gráfico de $\mathrm{pH}$ durante a operação do biofiltro

Embora na maior parte da operação do biofiltro o $\mathrm{pH}$ tenha se mantido dentro da faixa pretendida de operação $(6-8)$, em alguns pontos notou-se que o $\mathrm{pH}$ do percolado ficou fora dessa faixa, podendo ser explicados quando abaixo de 6 pela formação de compostos ácidos como mostrados na eq. 10 apresentada por Converti et al. (2001) e quando acima de 8 pela formação de polissulfetos como mostra a eq. 11 apresentada por Jones (1973). 


\subsection{Perfil de degradação do sulfeto ao longo do leito.}

Nos dias de operação 120 e 121 foram coletadas amostras da corrente gasosa em deferentes alturas do leito para se verificar avaliar o perfil de degradação do $\mathrm{H}_{2} \mathrm{~S}$ na coluna do biofiltro. As alturas que foram coletadas as concentrações são: Entrada $(0 \mathrm{~cm}), 10 \mathrm{~cm}$, $37 \mathrm{~cm}$ e na saída do biofiltro, que com a colmatação do leito foi considerada como sendo de $60 \mathrm{~cm}$.

Um gráfico do perfil de degradação do sulfeto no leito é apresentado na Figura 32.

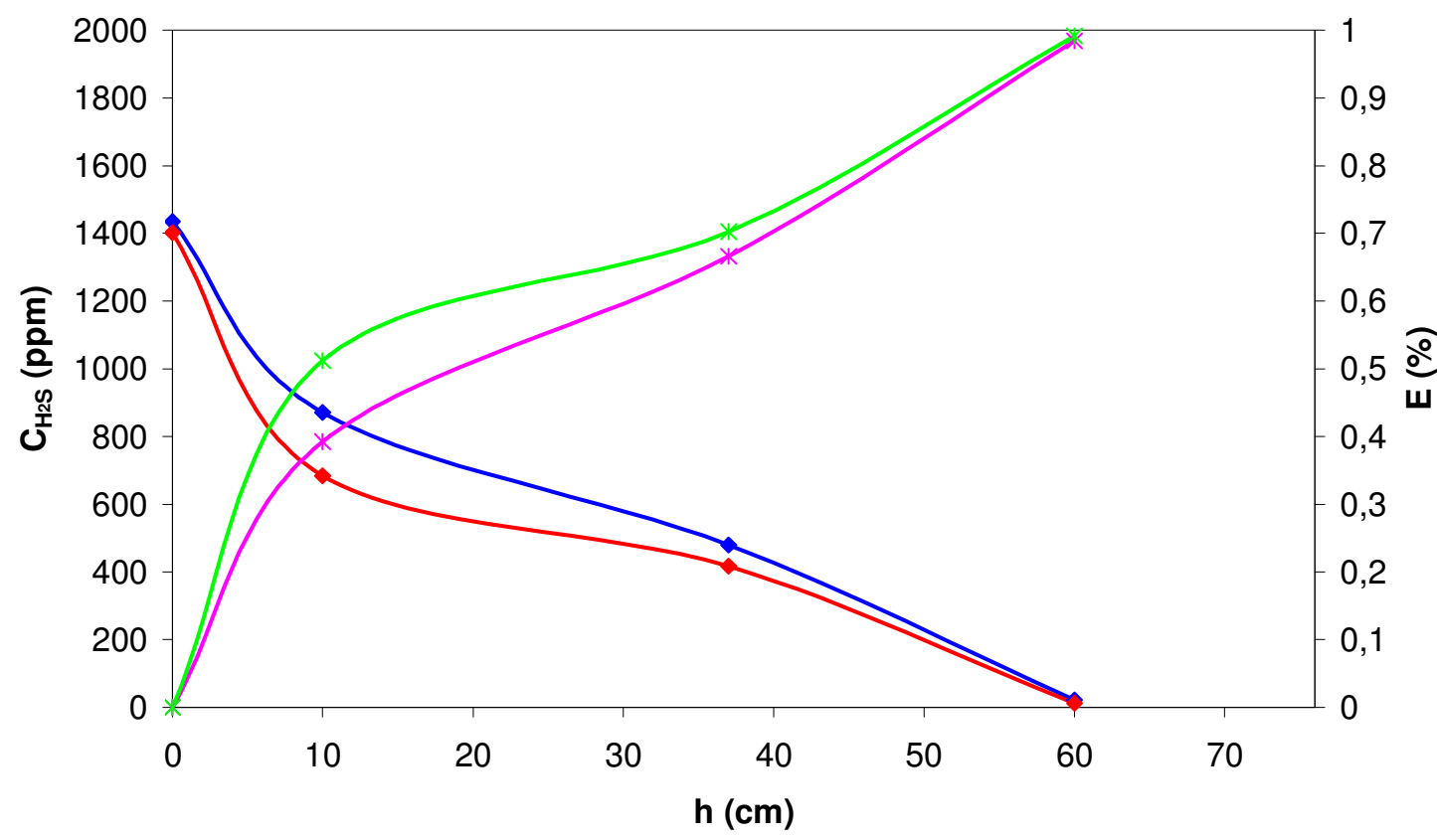

$$
\text { Dia } 120 \multimap-\text { Dia } 121 * \text { Dia } 120 \text { E\% *-Dia } 121 \mathrm{E} \%
$$

Figura 32. $\quad$ Perfil de degradação do sulfeto no leito.

$\mathrm{O}$ perfil de degradação no leito mostra que de 40 a $50 \%$ do $\mathrm{H}_{2} \mathrm{~S}$ é removido nos primeiros $10 \mathrm{~cm}$ de leito e a uma altura de $37 \mathrm{~cm}$ por volta de $70 \%$ do $\mathrm{H}_{2} \mathrm{~S}$ foi removido, o que é bem próximo do obtido por Morgan-Sagastume e Noyola, (2006) que trabalhando com um biofiltro de composto cerca de $63 \pm 10 \%$ do $\mathrm{H}_{2} \mathrm{~S}$ foi removido nos primeiros 40 cm de leito.

\subsection{A capacidade de eliminação}

A Figura 33 mostra a capacidade de eliminação do biofiltro em função da concentração de entrada do $\mathrm{H}_{2} \mathrm{~S}$. 


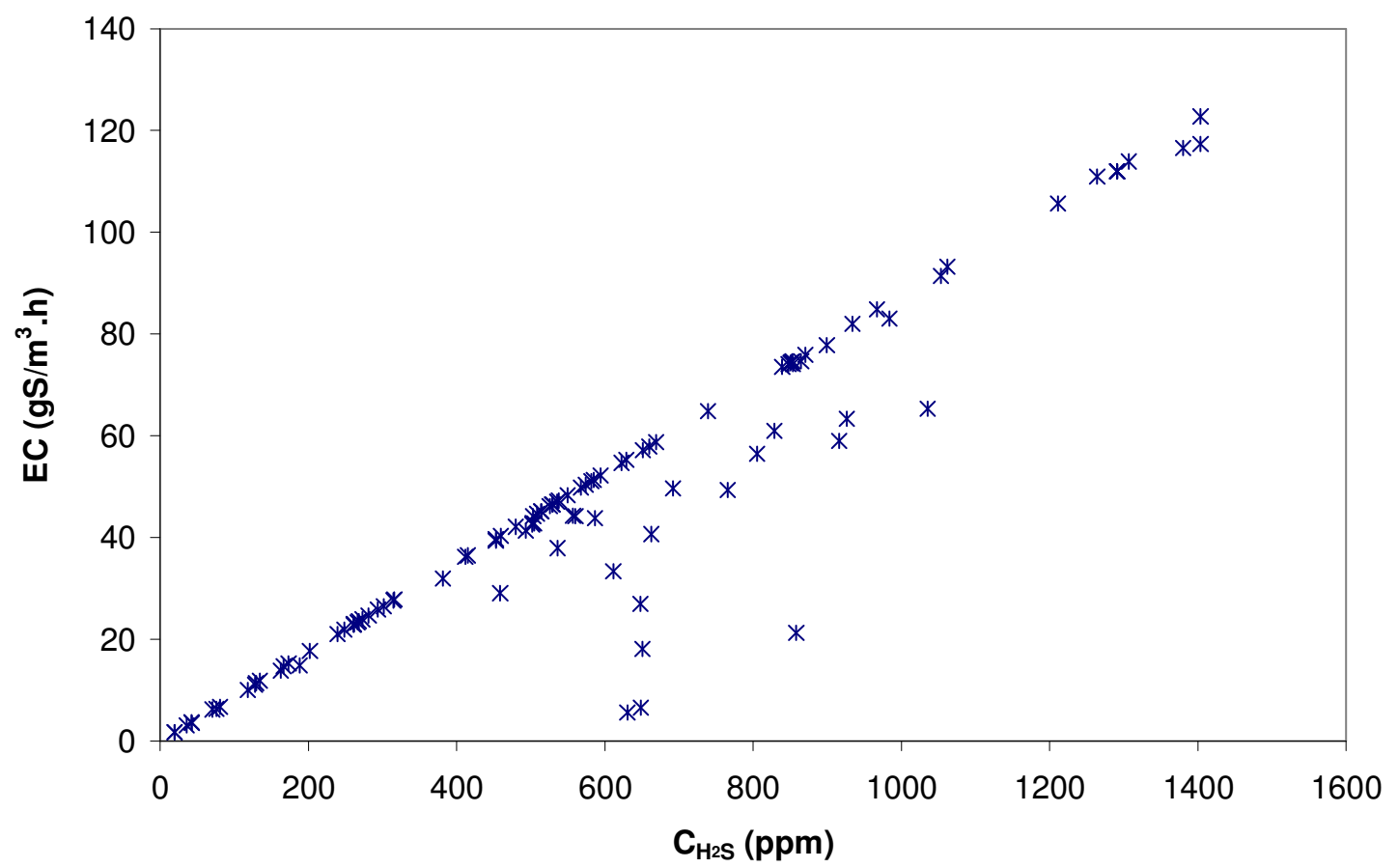

Figura 33. Capacidade de eliminação do biofiltro em função da concentração de entrada

A Figura 34 mostra um gráfico da capacidade de eliminação em função da taxa de carregamento.

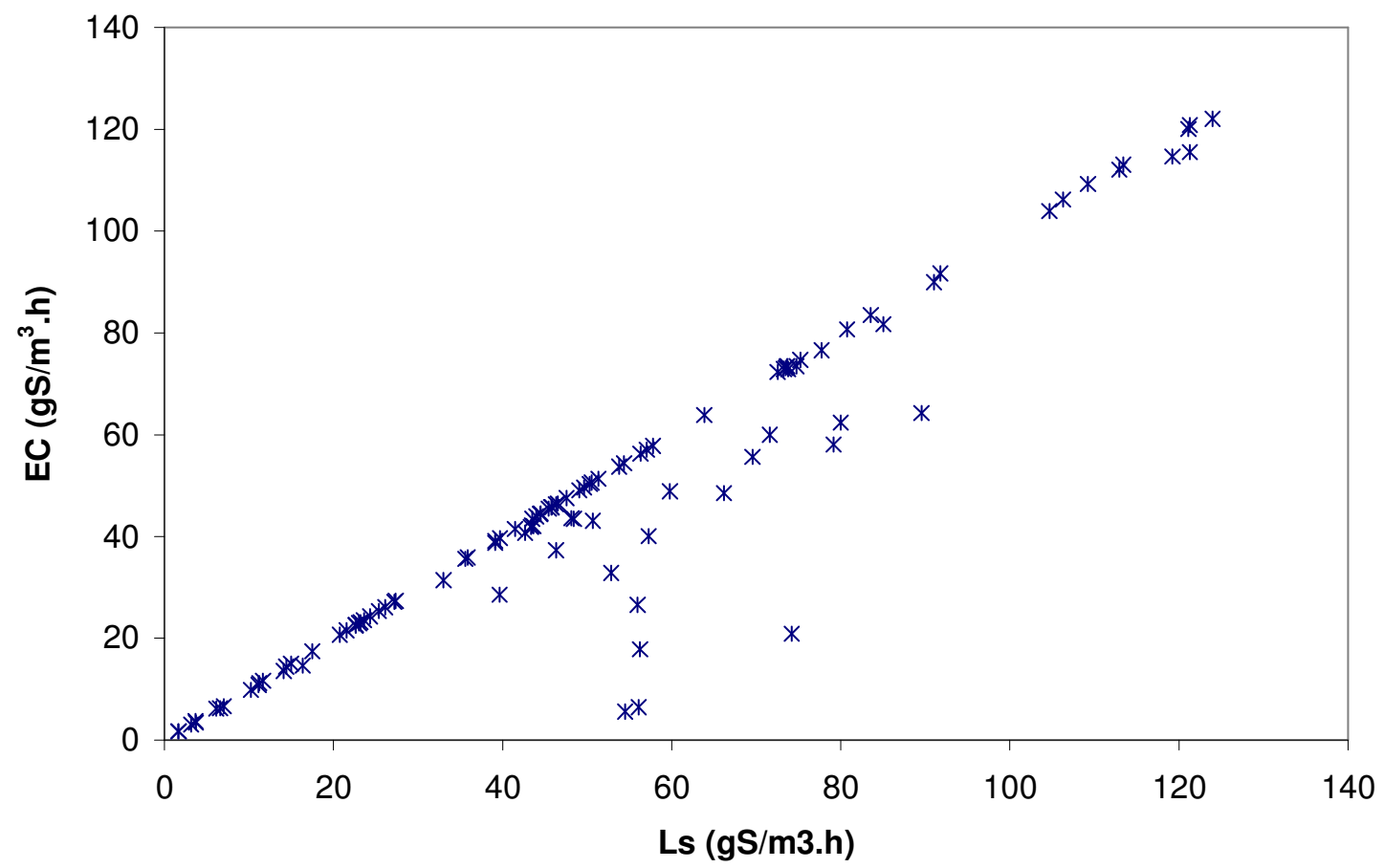

Figura 34. Capacidade de eliminação em função da taxa de carregamento.

O gráfico da Figura 33 tem a mesma tendência do gráfico da Figura 34 onde é mostrado que a capacidade de eliminação do sistema ainda não foi atingida. 
Com o auxilio do gráfico do perfil de degradação pode-se supor que caso a colmatação do leito não tivesse ocorrido a eficiência do sistema que atingiu cerca de $99 \%$ a uma altura de $60 \mathrm{~cm}$ poderia ter atingido os $100 \%$, essa hipótese também pode ser demonstrada corrigindo-se a altura do leito colmatado na sétima fase e plotando esses dados no gráfico da capacidade de eliminação, onde nota-se uma elevação na tendência da capacidade de eliminação $\left(\mathrm{E}_{\mathrm{C}}\right)$, como pode ser visto na Figura 35.

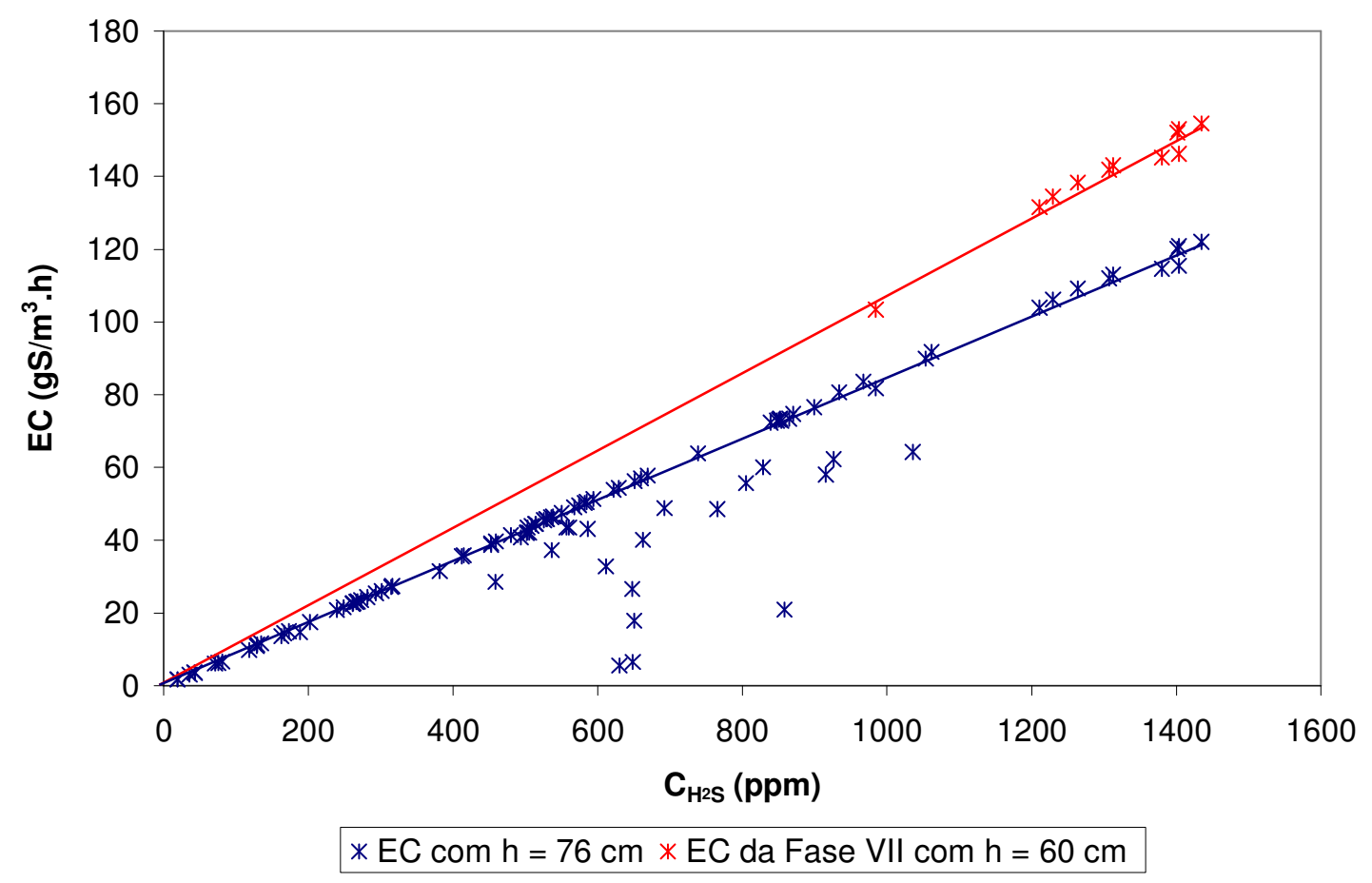

Figura 35. Capacidade de eliminação do biofiltro corrigida a altura do leito na sétima fase.

Os dados da capacidade de eliminação máximo e ótimo obtidos durante a operação do sistema são mostrados na Tabela 24.

TABELA 24 - Capacidade de eliminação máxima e ótima.

\begin{tabular}{ccc}
\hline Altura do Leito & EC $_{\text {máx }}$ & EC ótimo \\
\hline $76 \mathrm{~cm}$ & $122,03 \mathrm{~g} \cdot \mathrm{m}^{-3} \cdot \mathrm{h}^{-1}$ & $109,20 \mathrm{~g} \cdot \mathrm{m}^{-3} \cdot \mathrm{h}^{-1}$ \\
$60 \mathrm{~cm}$ & $154,57 \mathrm{~g} \cdot \mathrm{m}^{-3} \cdot \mathrm{h}^{-1}$ & $138,32 \mathrm{~g} \cdot \mathrm{m}^{-3} \cdot \mathrm{h}^{-1}$ \\
\hline
\end{tabular}

As capacidade de eliminação atingidas são superiores as encontradas por Hirai et al. (1990) com valores de $25 \mathrm{~g} \cdot \mathrm{m}^{-3} \cdot \mathrm{h}^{-1}$, Zhang et al. (1991) atingindo com diferentes tipos de inóculo valores de 15 e 30 g.m $\mathrm{m}^{-3} \cdot \mathrm{h}^{-1}$, Cho et al. (1992a) encontrou valores de $50 \mathrm{~g} \cdot \mathrm{m}^{-3} \cdot \mathrm{h}^{-1}$, Chung et al. (1996a) atingiu valores ótimos de $25 \mathrm{~g} \cdot \mathrm{m}^{-3} \cdot \mathrm{h}^{-1}$ e máximos $33 \mathrm{~g} \cdot \mathrm{m}^{-3} \cdot \mathrm{h}^{-1}$, LI et al. (1998) encontrou valores máximos de $63,4 \mathrm{~g} \cdot \mathrm{m}^{-3} \cdot \mathrm{h}^{-1}$, Wani et al. (1998) atingindo cerca de $81 \mathrm{~g} \cdot \mathrm{m}^{-3} \cdot \mathrm{h}^{-1}$, Elias et al. (2002) tratou até $45 \mathrm{~g} \cdot \mathrm{m}^{-3} \cdot \mathrm{h}^{-1}$ com eficiências de $100 \%$, Malhautier 
et al. (2003) atingiu valores de $28 \mathrm{~g} \cdot \mathrm{m}^{-3} \cdot \mathrm{h}^{-1}$ e Oyarzún et al. (2003) com valores máximos de $55 \mathrm{~g} \cdot \mathrm{m}^{-3} \cdot \mathrm{h}^{-1}$ e ótimo de $45 \mathrm{~g} \cdot \mathrm{m}^{-3} \cdot \mathrm{h}^{-1}$.

A Tabela 25 mostra um resumo dos trabalhos realizados em biofiltração com as máximas capacidades de eliminação encontradas e os microrganismos utilizados como inóculo.

TABELA 25 - Capacidade de eliminação máxima encontrada em pesquisas anteriores.

\begin{tabular}{|c|c|c|c|}
\hline Autor & $\begin{array}{c}\mathrm{E}_{\mathrm{C}} \\
\left(\mathrm{g} \cdot \mathrm{S}^{-} \cdot \mathrm{m}^{-3} \cdot \mathrm{h}^{-1}\right)\end{array}$ & Suporte & Inóculo \\
\hline $\begin{array}{l}\text { Hirai et al. } \\
\text { (1990) }\end{array}$ & 25 & Turfa & Resíduo sólido \\
\hline $\begin{array}{l}\text { Zhang et al. } \\
\text { (1991) }\end{array}$ & 30 & Turfa & Resíduo sólido \\
\hline $\begin{array}{l}\text { Zhang et al. } \\
\text { (1991) }\end{array}$ & 15 & Turfa & $\begin{array}{l}\text { Thiobacillus } \\
\text { thioparus }\end{array}$ \\
\hline $\begin{array}{l}\text { Cho et al. } \\
\text { (1991) }\end{array}$ & 50 & Turfa & Thiobacillus HA43 \\
\hline $\begin{array}{l}\text { Cho et al. } \\
\text { (1992a) }\end{array}$ & 25 & Turfa & $\begin{array}{l}\text { Thiobacillus } \\
\text { thioparus DW44 }\end{array}$ \\
\hline $\begin{array}{l}\text { Cho et al. } \\
\text { (1992b) }\end{array}$ & 14 & Turfa & Xanthomonas DY44 \\
\hline $\begin{array}{l}\text { Kowal et al. } \\
\quad(1992)\end{array}$ & 500 & Lodo ativado seco & Não Utilizou \\
\hline $\begin{array}{l}\text { Yang \& Allen } \\
\quad(1994)\end{array}$ & 130 & Composto & Não Utilizou \\
\hline $\begin{array}{l}\text { Chung et al. } \\
\text { (1996a) }\end{array}$ & 33 & Alginato de Cálcio & $\begin{array}{l}\text { Thiobacillus } \\
\text { thioparus }\end{array}$ \\
\hline $\begin{array}{l}\text { Li et al. } \\
\text { (1998) }\end{array}$ & 63 & $\begin{array}{l}\text { Fibra plástica utilizada em coifas de } \\
\text { cozinha como filtro de óleo }\end{array}$ & Lodo ativado \\
\hline $\begin{array}{l}\text { Wani et al. } \\
\text { (1998) }\end{array}$ & 81 & $\begin{array}{l}\text { Composto, Resíduo de jardinagem } \\
\text { e uma mistura dos dois meios }\end{array}$ & Não Utilizou \\
\hline $\begin{array}{l}\text { Elias et al. } \\
\quad(2002)\end{array}$ & 45 & $\begin{array}{c}\text { Pellets de estrume de porco e } \\
\text { serragem }\end{array}$ & Não Utilizou \\
\hline $\begin{array}{l}\text { Oyarzún et al. } \\
\qquad(2003)\end{array}$ & 55 & Turfa & $\begin{array}{c}\text { Thiobacillus } \\
\text { thioparus }\end{array}$ \\
\hline $\begin{array}{l}\text { Malhautier et } \\
\text { al. (2003) }\end{array}$ & 28 & $\begin{array}{l}\text { Lodo desidratado proveniente de } \\
\text { uma estação de tratamento de } \\
\text { esgoto }\end{array}$ & Lodo ativado \\
\hline $\begin{array}{l}\text { Lee et al. } \\
\text { (2005) }\end{array}$ & 815 & Partículas de cerâmica & $\begin{array}{l}\text { Acidithiobacillus } \\
\text { thiooxidans TAS }\end{array}$ \\
\hline Este Trabalho & 155 & Espuma de Poliuretano & Lodo ativado \\
\hline
\end{tabular}

A capacidade de eliminação máxima encontrada no estudo considerando a redução da altura do leito foi de aproximadamente $155 \mathrm{~g} \cdot \mathrm{m}^{-3} \cdot \mathrm{h}^{-1}$, o que está de acordo com a obtida por Yang e Allen (1994) de cerca de $130 \mathrm{~g} \cdot \mathrm{m}^{-3} \cdot \mathrm{h}^{-1}$, mas como mostrado nos gráficos das 
figuras 23 e 24, a capacidade máxima de eliminação real ainda não foi encontrada, pois os pontos ainda mostram uma tendência de aumento na capacidade de eliminação sendo possível então atingir valores como encontrados por Kowal et al. (1992) da ordem de 500 g. $\mathrm{m}^{-3} \cdot \mathrm{h}^{-1}$ e Lee et al. (2005) com uma capacidade máxima de $815 \mathrm{~g} \cdot \mathrm{m}^{-3} \cdot \mathrm{h}^{-1}$.

\subsection{Microscopia Óptica}

Geralmente as bactérias presentes nos processos de lodo ativado são gramnegativas e incluem os gêneros Pseudomonas, Zoogloea, Achromobacter, Flavobacterium, Nocardia, Bdellovibrio, Mycobacterium e duas bactérias nitrificantes, Nitrosomonas e Nitrobacter. Também são encontradas várias morfologias filamentosas como Sphaerotilus, Beggiatoa, Thiothrix, Lecicothrix e Geotrichum (METCALF \& EDDY, 1979).

Foram realizadas microscopias ópticas da biomassa crescida no reator alimentado durante sete dias (Figuras 36 e 37) com meio de cultura ATCC 290 S6 e, também de amostras do percolado retirado do mesmo sistema.

As Figura 36 e 37 mostram algumas morfologias bacterianas presentes na biomassa alimentada com o meio de cultura da ATCC por sete dias.

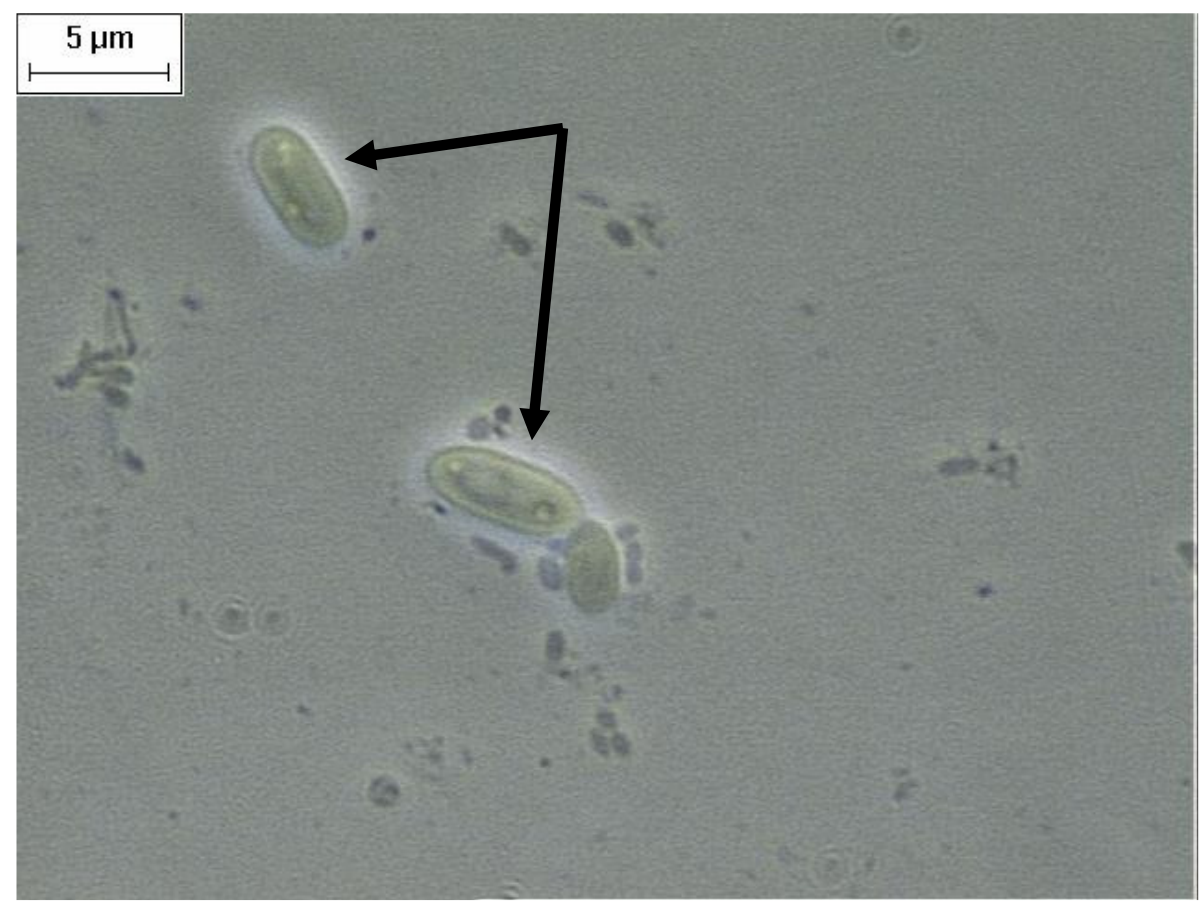

Figura 36. Microscopia óptica de contraste da fase da biomassa destacando a presença de protozoários. 


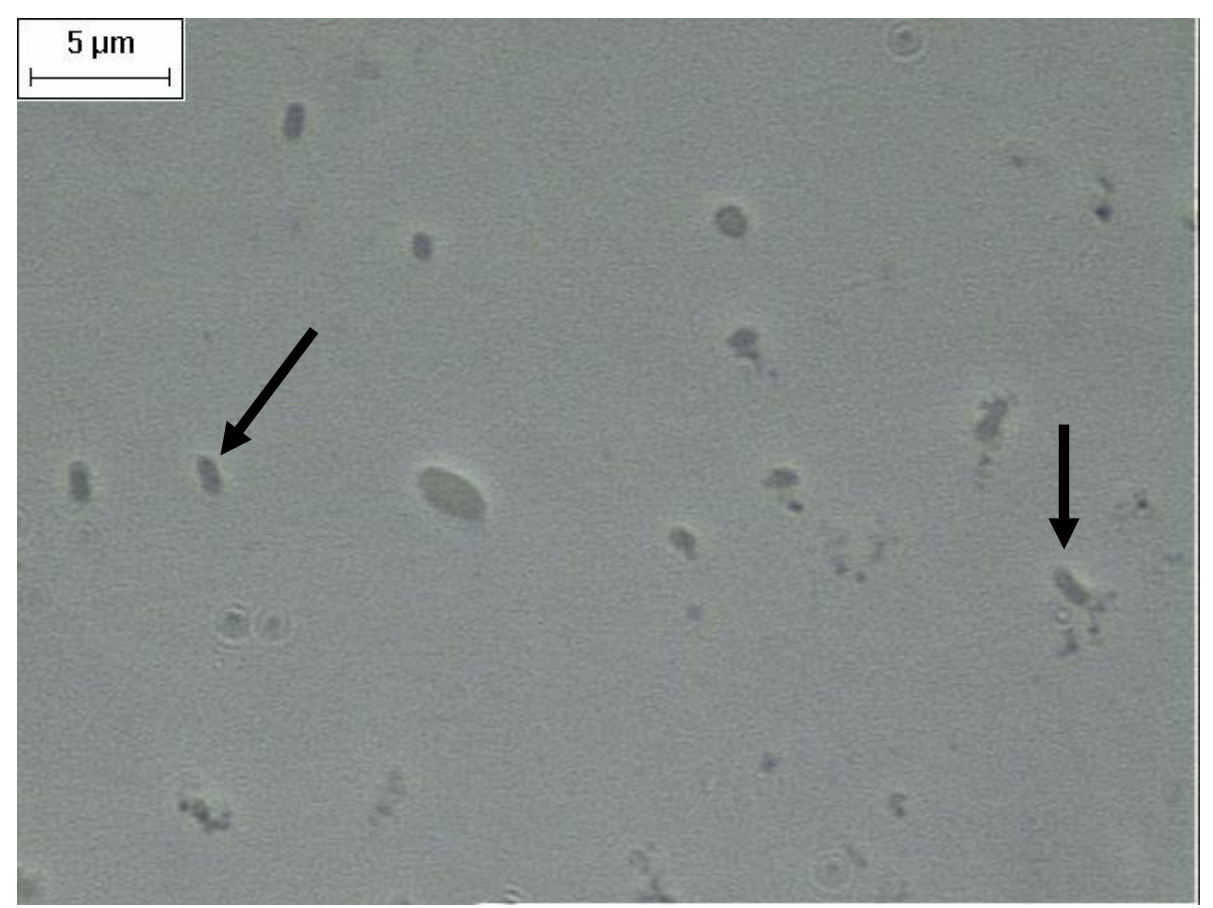

Figura 37. Microscopia óptica de contraste da fase da biomassa destacando a presença de bacilos

As morfologias mais encontradas foram algumas formas de bacilos.

A figura 38 mostra microscopia óptica do percolado no $64^{\circ}$ dia de operação.

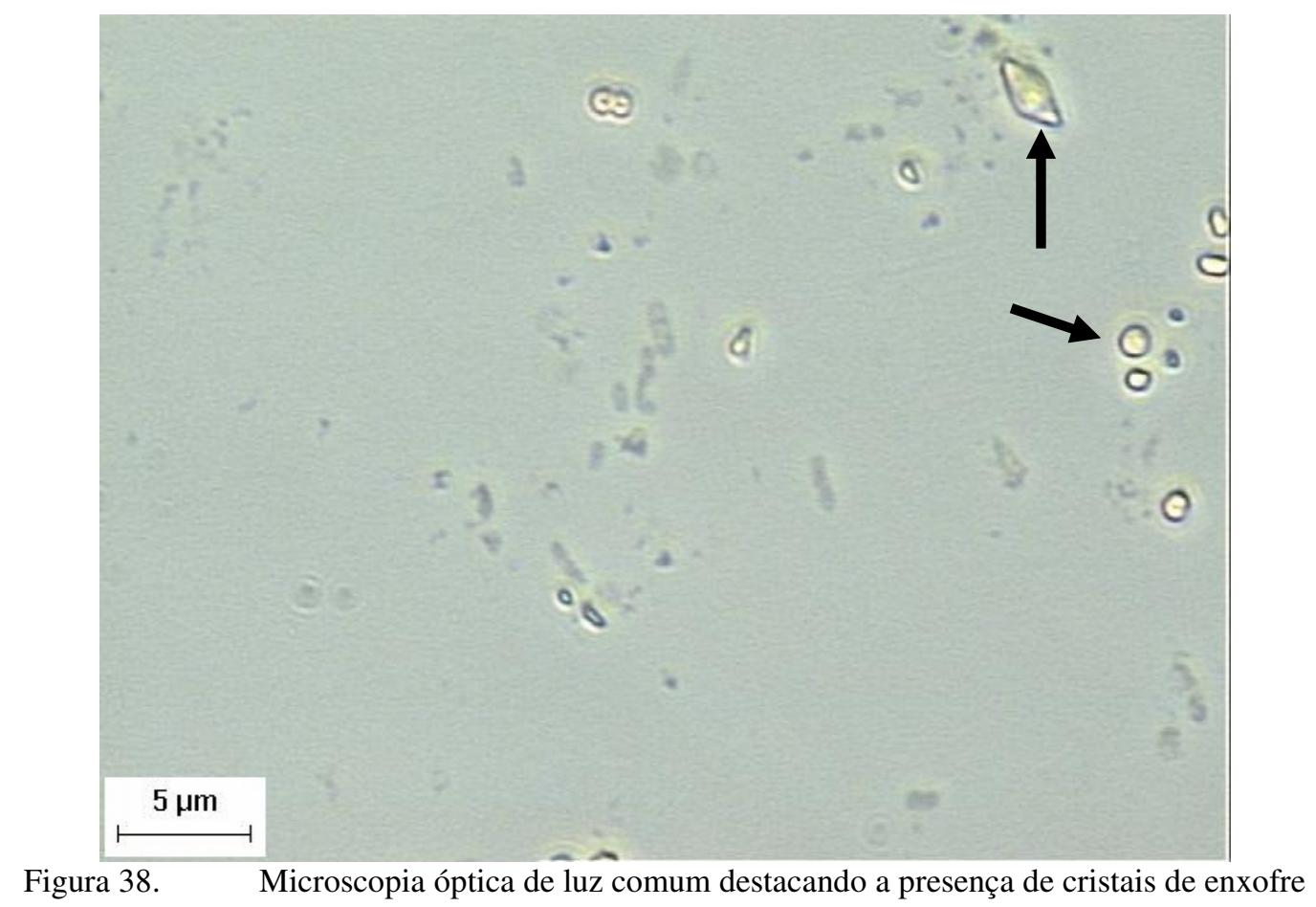

Nas fotos de microscopia óptica do percolado do biofiltro foi difícil observar as morfologias microbianas conseguindo apenas se visualizar a ocorrência de alguns bacilos, 
pois os tamanhos dos grânulos de enxofre formados eram muito maiores que os microrganismos.

\subsection{Microscopia Eletrônica de Varredura}

Foi realizada microscopia eletrônica de varredura (MEV) da espuma de poliuretano antes de serem colocadas no biofiltro e durante a operação do biofiltro. Durante a operação também foram realizadas análises de EDX para comprovar o acúmulo de enxofre elementar $\left(S^{0}\right)$ no meio suporte como foi identificado pela Microscopia Óptica e MEV.

As Figura 39, 40 e 41 mostram as morfologias observadas com amostras do biofiltro obtidas logo após a inoculação.

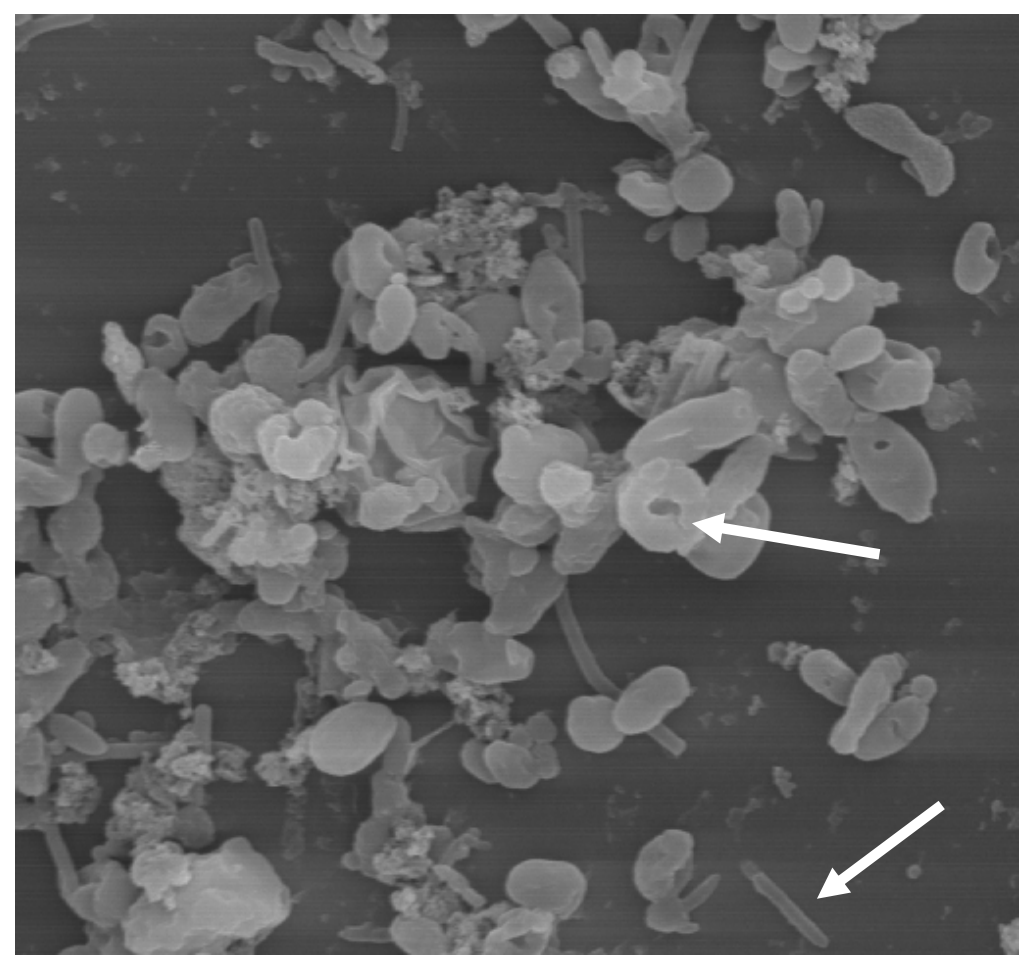

Figura 39. MEV da espuma de poliuretano com aumento de 3000x, após inoculação com lodo: bacilos e protozoários. 


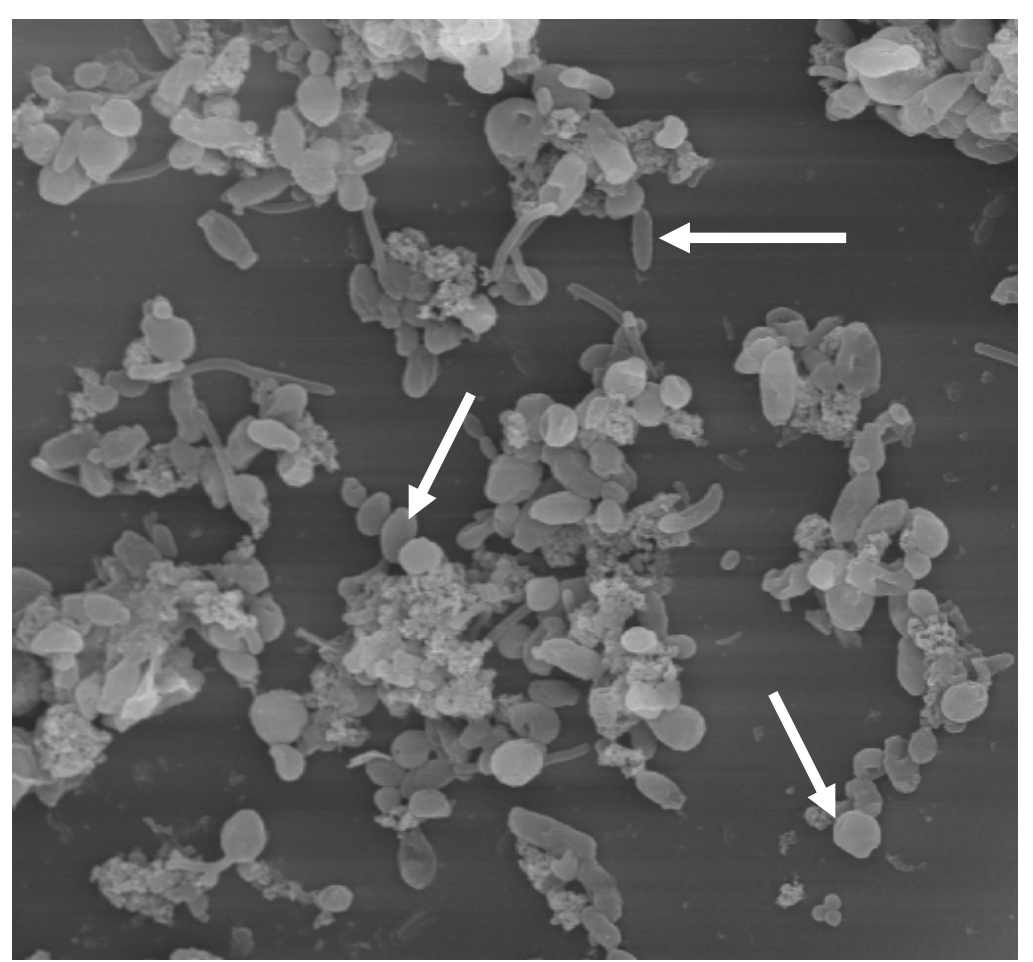

Figura 40. MEV da espuma de poliuretano com aumento de 2000x, após inoculação com lodo: bacilos e coco-bacilos

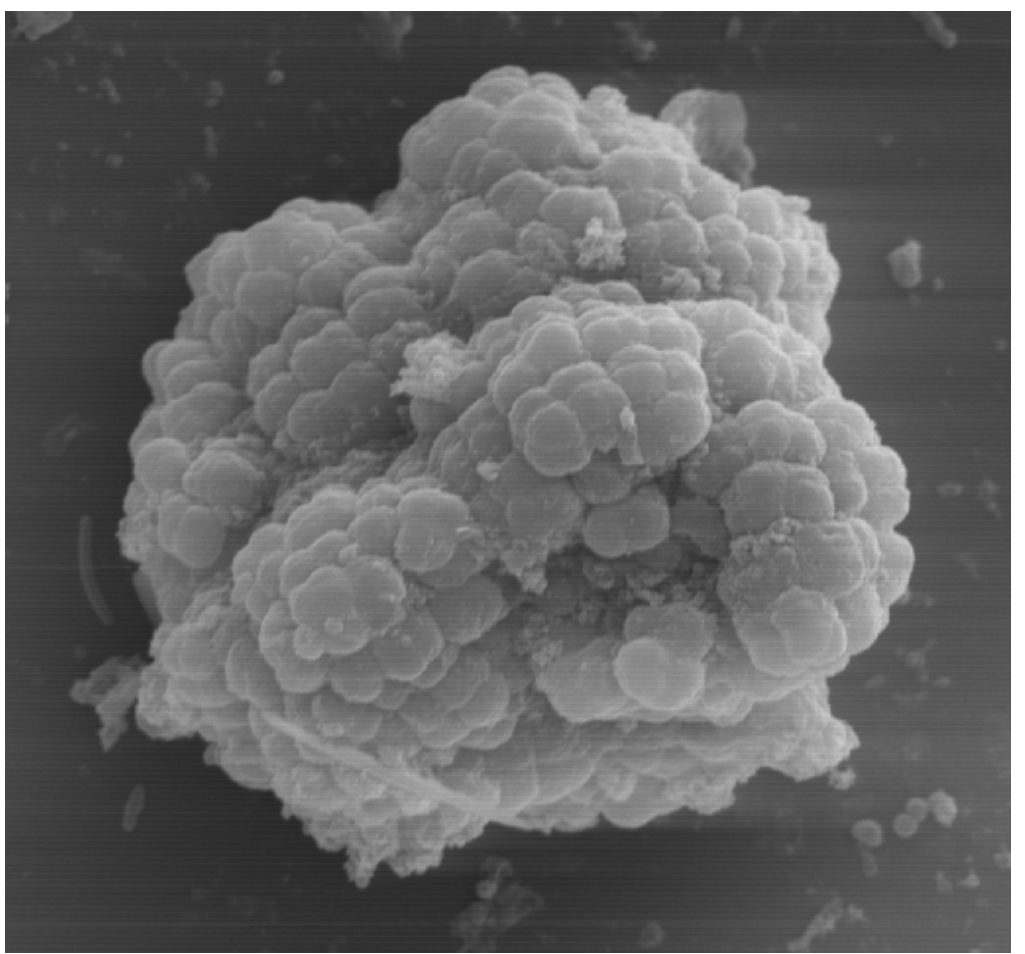

Figura 41.

MEV da espuma de poliuretano com aumento de 2500x, após inoculação com lodo: sarcina.

As Figuras 39, 40 e 41 destacam que as principais morfologias que apareceram foram bacilos, bacilos curvos, cocos e algumas sarcinas aeróbias. 
Nas Figuras 42, 43 e 44 são apresentadas as microscopias eletrônica de varredura após 71 dias de operação do sistema.

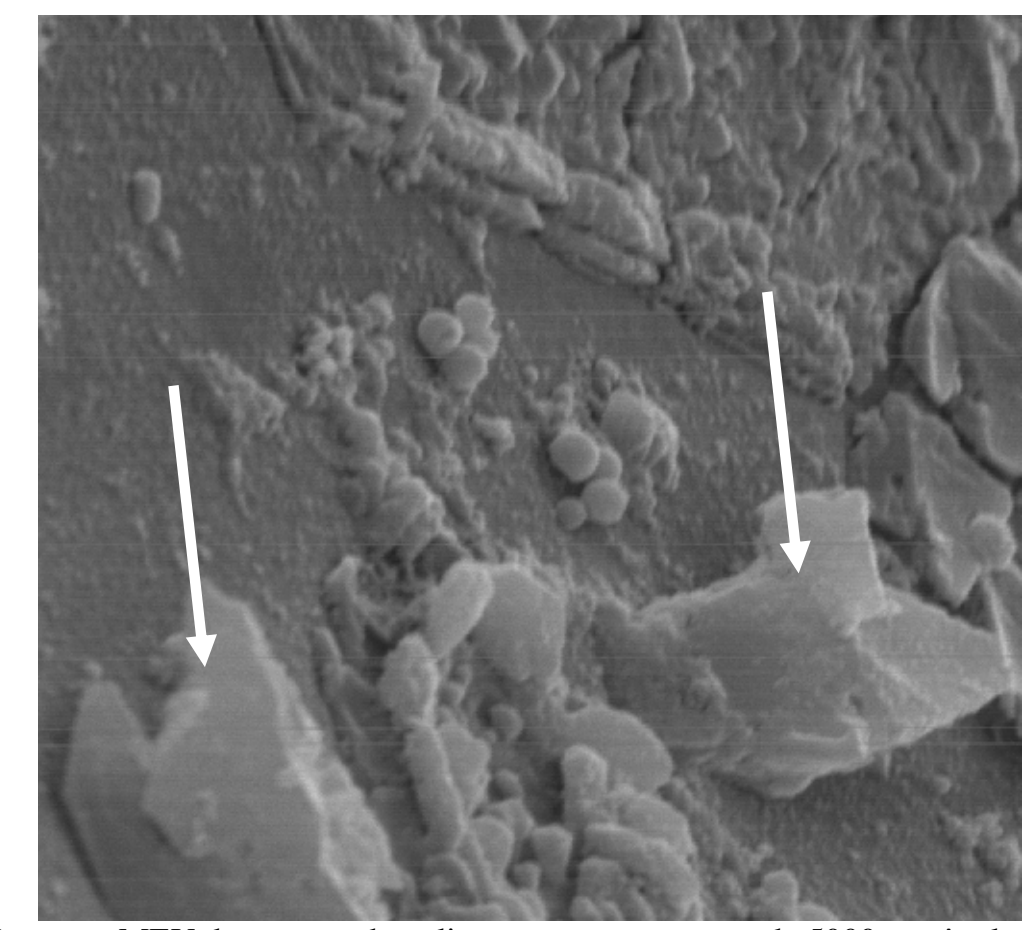

Figura 42.

MEV da espuma de poliuretano com aumento de 5000x: grânulos de enxofre

Na Figura 42 nota-se um grande acúmulo de grânulos de enxofre extracelular e, também, nota-se também a redução de morfologias encontradas sendo observadas apenas alguns cocos e bacilos.

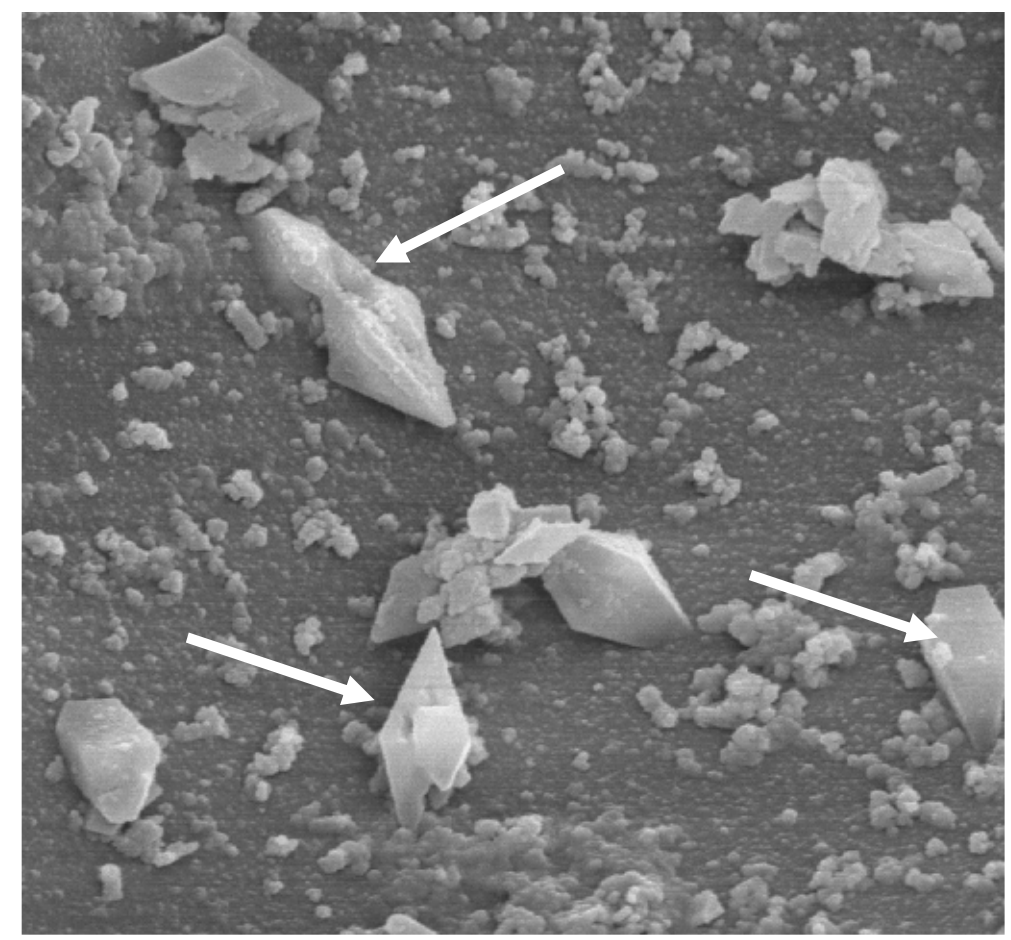

Figura 43. MEV da espuma de poliuretano com aumento de 3000x:grânulos de enxofre. 
Na Figura 43 pode-se notar a estrutura dos grânulos de enxofre formados. A mesma estrutura pode ser visualizada na Figura 38 em microscopia óptica.

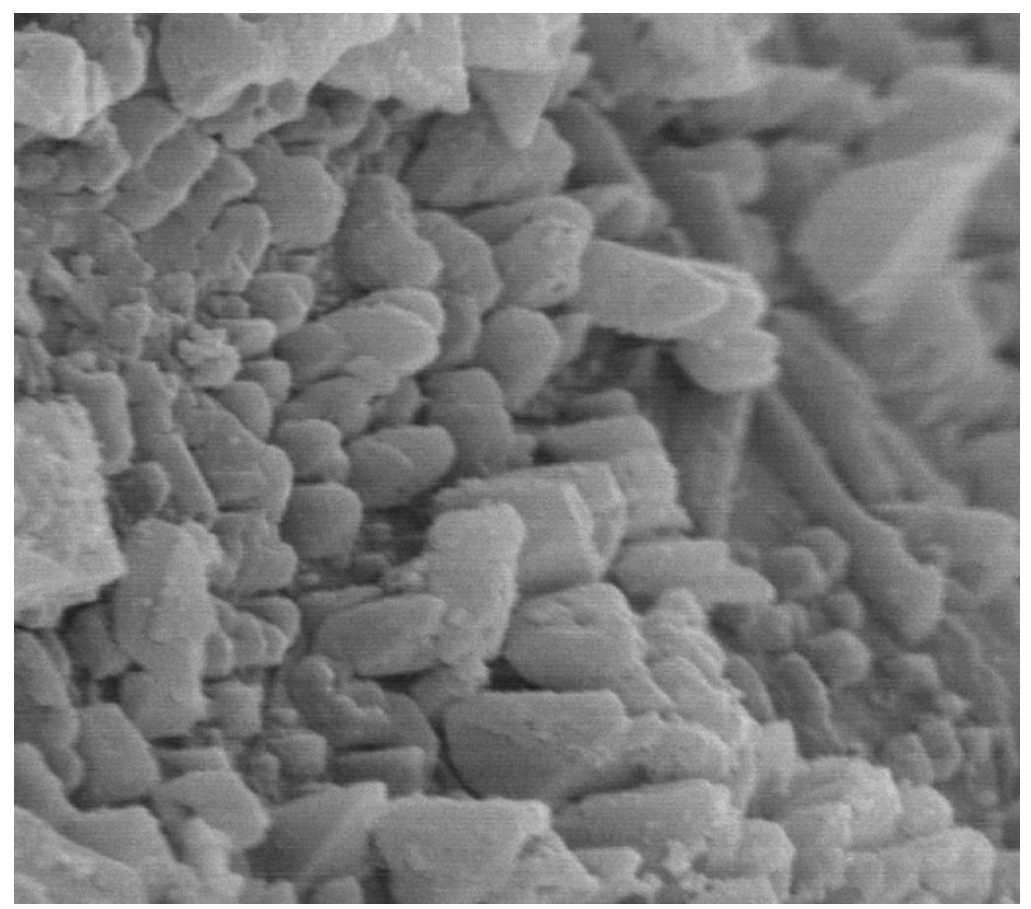

Figura 44. MEV com aumento de 5000x: grânulos de enxofre.

Na Figura 44 tem-se uma melhor noção da quantidade de grânulos de enxofre formado nos poros da espuma de poliuretano.

Na MEV observou-se a ocorrência de alguns microrganismos em meio a grande quantidade de grânulos de enxofre.

A confirmação de que os grânulos encontrados tanto na MEV quanto na microscopia ótica eram de enxofre elementar foi dada pela análise de EDX realizada em que os resultados são mostrados na Tabela 26.

TABELA 26 - Resultados obtidos pelo EDX.

\begin{tabular}{ccc}
\hline Elemento & \% do Elemento & \% Atômica \\
\hline $\mathrm{Na}$ & 14,12 & 19,08 \\
$\mathrm{~S}$ & 79,60 & 77,14 \\
$\mathrm{~K}$ & 1,45 & 1,15 \\
$\mathrm{Ca}$ & 0,40 & 0,31 \\
$\mathrm{Fe}$ & 2,23 & 1,24 \\
$\mathrm{Cu}$ & 2,20 & 1,08 \\
\hline
\end{tabular}




\subsection{Colmatação do Leito}

Durante o período em que o biofiltro ficou sem a adição de $\mathrm{H}_{2} \mathrm{~S}$ na corrente gasosa notou-se uma colmatação do leito em tordo de $16 \mathrm{~cm}$ como é ilustrado pela Figura 45, essa redução da altura do leito foi considerada no calculo da perda de carga $(\Delta \mathrm{P} / \mathrm{L})$.

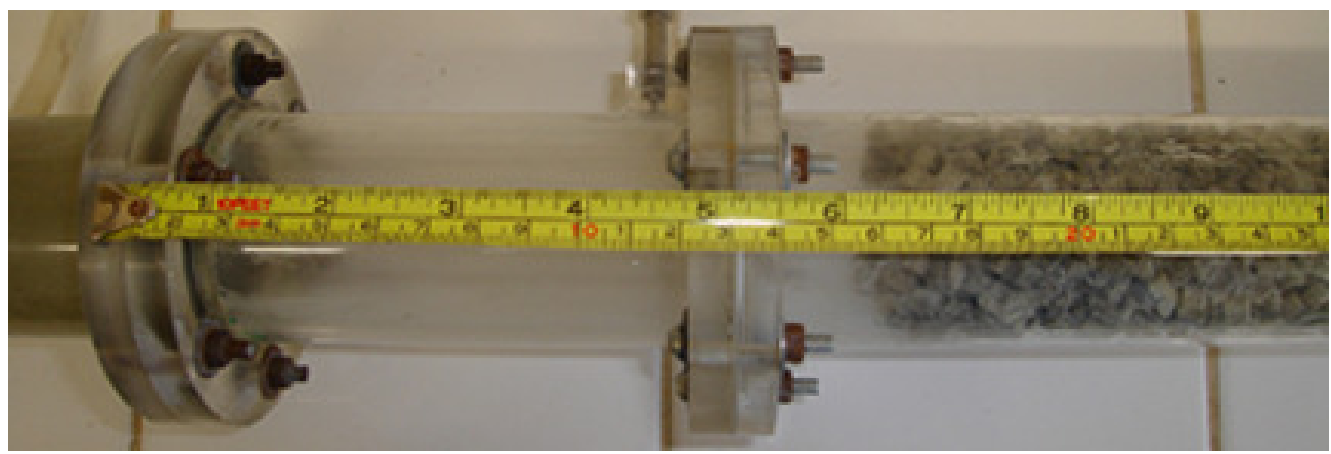

Figura 45. Colmatação do leito de espuma.

Após 121 dias de operação do biofiltro foi realizada a desmontagem e foram tiradas algumas fotos da espuma a após ter sido retirada da coluna.

A figura 46, 47 e 48 mostram uma fotos do biofiltro antes de ser desmontado, fotos comparativas das espumas limpas e após a sua retirada do biofiltro. 


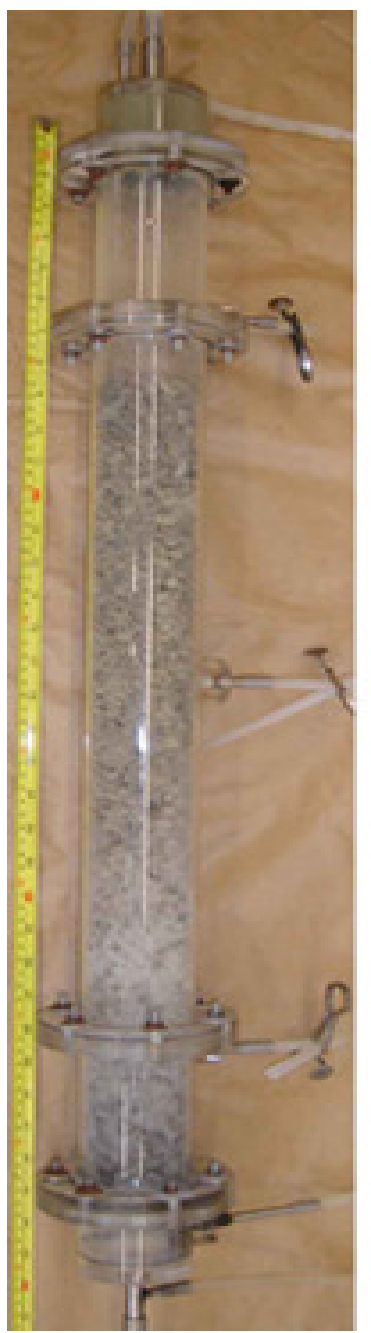

Figura 46.
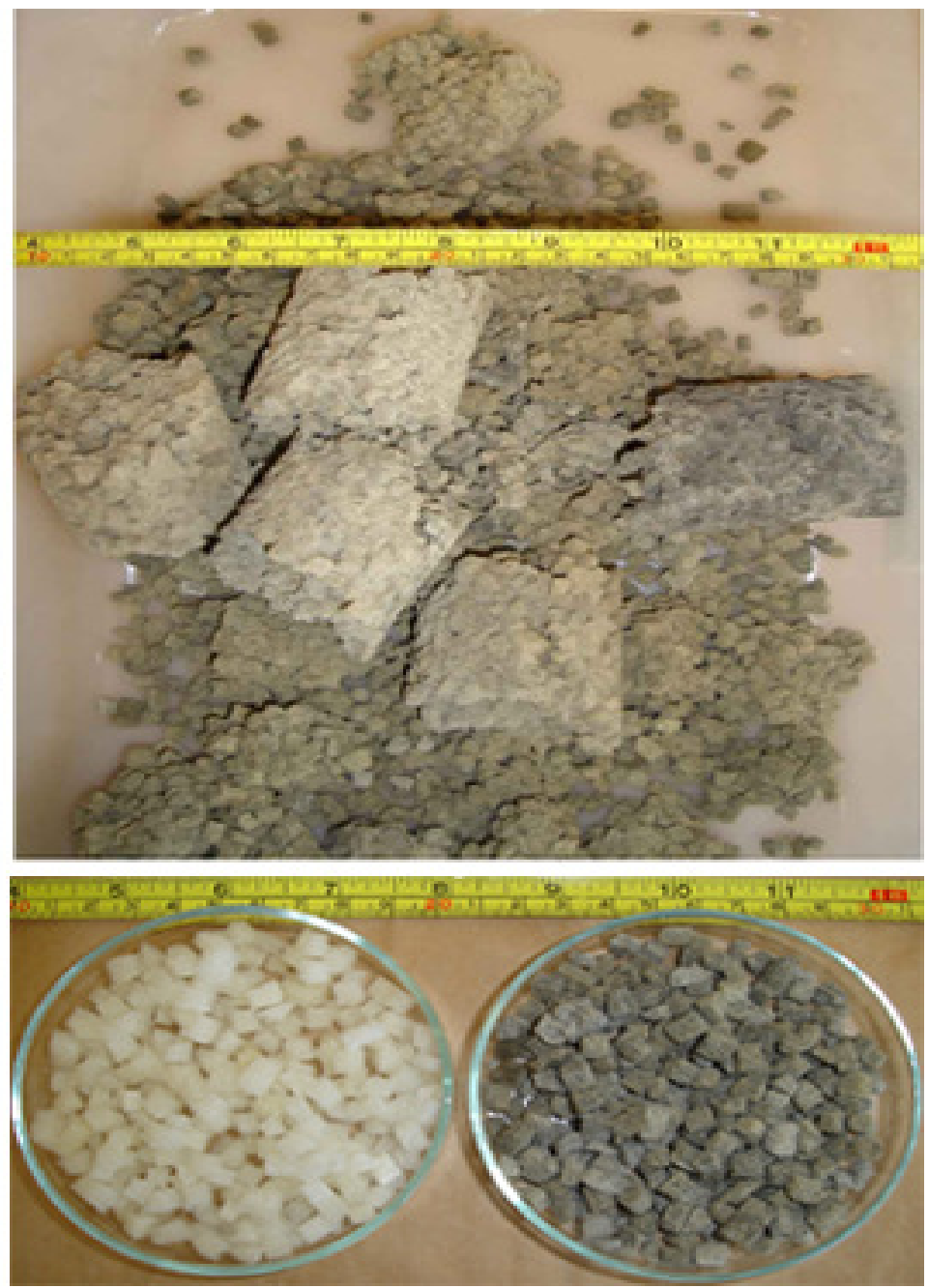

Fotos das espumas utilizadas no biofiltro.

Após a retirada da espuma do biofiltro notou-se um arredondamento nas arestas das espumas, juntamente com um visível acumulo de enxofre nos poros da espuma. 


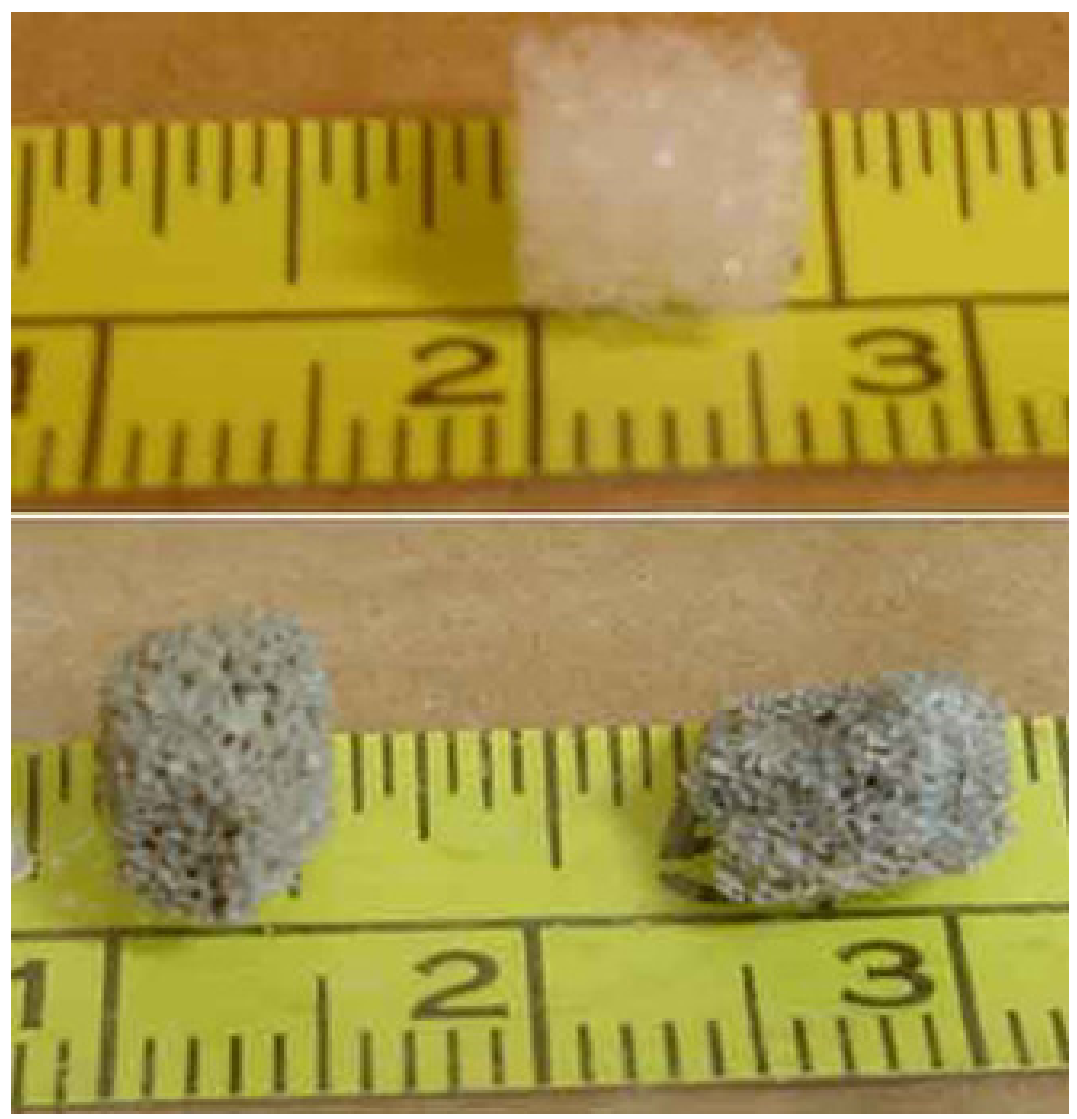

Figura 47. Detalhe da deformação da espuma.

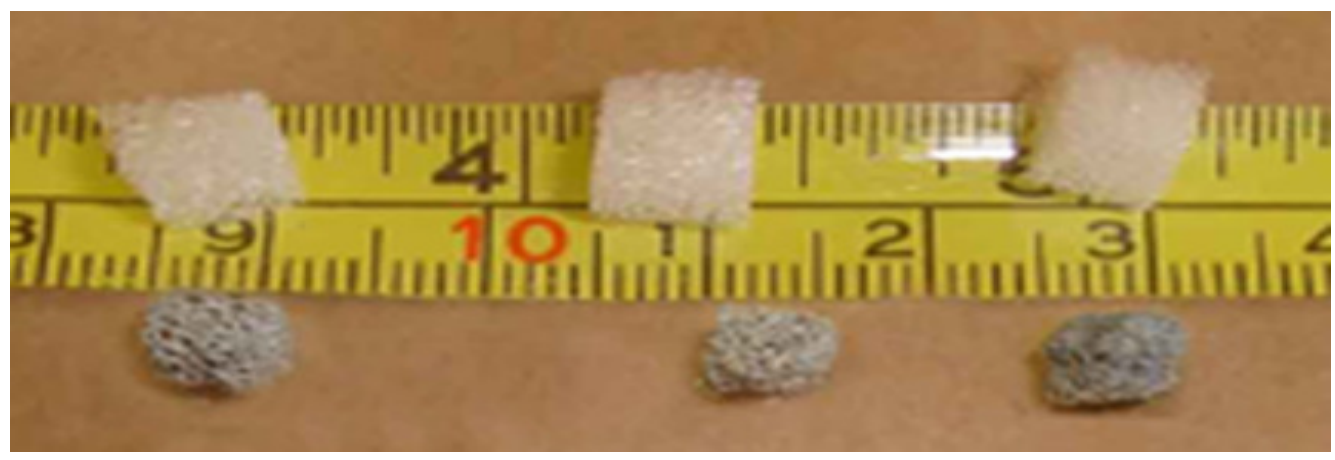

Figura 48. Foto comparativa da redução de tamanho das espumas.

Nas Figuras 47 e 48 pode-se notar que com a colmatação do leito algumas espumas sofreram redução de tamanho, essa redução fica mais evidente na Figura 48 onde foram comparadas as espumas limpas e na Figura 47 onde é melhor ilustrado a deformação da espuma.

A colmatação do leito pode ter ocorrido devido ao acúmulo de enxofre no interior das espumas, ao crescimento da biomassa, ao tempo de operação, mas também pode ter sido em função dos problemas operacionais ou da paralisação do sistema. Um detalhe observado foi o de que após uma lavagem dessa espuma para a retirada os grânulos de enxofre elas retornam ao tamanho e forma original, mas com uma menor resistência. 


\section{CONCLUSÕES}

Com o que foi desenvolvido neste trabalho, pode-se apresentar as seguintes conclusões:

Quanto aos ensaios hidrodinamicos

- Os ensaios de perda de carga da espuma de poliuretano úmida apresentaram um bom ajuste a equação de DARCY, proposta para avaliar a permeabilidade do meio.

- As determinações de perda de carga em espuma úmida $\left(0,56.10^{-2}\right.$ mca) e no leito após a desativação do sistema $\left(0,78.10^{-2} \mathrm{mca}\right)$ ilustram a baixa perda de carga inerente a este material, o que é uma grande vantagem em termos de economia de energia do processo.

- Mesmo com a colmatação do leito em $16 \mathrm{~cm}$ os valores de perda de carga continuaram baixos, não afetando a viabilidade de utilização desse suporte.

Quanto ao inóculo

- A utilização de lodos ativados como inóculo o inóculo do sistema de biofiltração para tratamento de sulfeto de hidrogênio se mostrou bastante viável pelas altas eficiências atingidas (100\%) na remoção do sulfeto e a rápida partida do sistema (8 dias para atingir a eficiência de 100\%).

Quanto ao meio suporte

- A espuma de poliuretano se mostrou um suporte bastante adequado, e os caminhos preferenciais que ocorrem nesse suporte não afetaram a eficiência do sistema nas condições trabalhadas.

- A colmataçào do leito em virtude do acumulo de enxofre nos poros da espuma de poliuretano, não afetou consideravelmente a eficiência do sistema, nem a sua hidrodinâmica.

Quanto ao biofiltro

- O tempo de detenção de 58 segundos mostrou-se viável para este sistema. 
- A adoção de um sistema de recirculação do percolado foi eficiente na umidificação do leito.

- A alimentação diária do sistema com uma fonte de bicarbonato se mostrou adequada para a manutenção do pH na faixa de 6-8.

- As concentrações de sulfeto tratadas (141 a 1303 ppm) estão em uma faixa que abrange grande parte das emissões industriais e também das concentrações emitidas nos tratamento biológico, podendo assim utilizar esse sistema para o tratamento de efluentes gasosos da maior parte das indústrias.

- As eficiências atingidas nesse estudo se mantiveram acima dos $90 \%$ e muito próximas a $100 \%$ sendo viável a aplicação desse sistema como única unidade de tratamento.

- A capacidade de eliminação de sulfeto do sistema não foi alcançada mas as capacidade de eliminação ótimas e máximas são respectivamente 138,32 e 154,57 g. $\mathrm{m}^{-3} \cdot \mathrm{h}^{-1}$.

- Paralisações no sistema por determinado período do tempo (15 dias) não afetam a eficiência e estabilidade do sistema, podendo o mesmo após a sua paralisação voltar a funcionar com concentrações igual ou superiores a anteriormente trabalhadas. 


\section{DIFICULDADES EXPERIMENTAIS}

A principal dificuldade experimental encontrada foi com relação a manter a concentração do $\mathrm{H}_{2} \mathrm{~S}$ constante, pois essa tinha uma tendência e aumentar com o passar do tempo e também as variações de vazão tanto da corrente de ar comprimido quanto a de $\mathrm{H}_{2} \mathrm{~S}$ variavam ao longo do dia.

O tempo de resposta da válvula agulha que controlava a vazão do $\mathrm{H}_{2} \mathrm{~S}$ também foi uma dificuldade a se superar pois ao se ajustar uma concentração, só seria possível verificar a concentração real em cerca de 2 a 3 horas caso o ajuste fosse pequeno, caso o ajuste fosse grande como o depois de uma parada no sistema só seria possível verificar a concentração real depois de cerca de 24 horas.

A liberação do odor característico ocorrida no sistema era proveniente dos acessórios instalados antes da entrada no biofiltro que em sua maioria não era em inox, isso fez com que se mantivesse uma grande e constante preocupação durante toda a realização da parte experimental pela periculosidade do $\mathrm{H}_{2} \mathrm{~S}$, como o sistema foi construído dentro do laboratório e esse apresenta pouca circulação de ar e qualquer vazamento no laboratório poderia se tornar perigoso.

A realização da ultima fase de operação do sistema precisou ser realizada com uma atenção redobrada pelo aumento da intensidade do odor no laboratório, ocorrida devido a corrosão de algumas conexões em latão, o odor ficava mais intenso quando eram necessárias correções na vazão e tinha que se mexer em algum registro feito em latão. 


\section{SUGESTÕES DE CONTINUIDADE}

As sugestões para dar continuidade a este trabalho são:

- Efetuar toda a instalação do sistema com conexões em inox;

- Instalar um fluxômetro de massa para se ter um melhor controle das concentrações de entrada;

- Estudar outros meios de suporte alternativos, assim como uma mistura deles, verificando a influência da umidade nas perdas de carga e nas eficiências do sistema;

- Estudar diferentes técnicas e a viabilidade destas para a recuperação do enxofre formado na espuma de poliuretano;

- Estudar a cinética de crescimento do lodo ativado para tratamento de $\mathrm{H}_{2} \mathrm{~S}$;

- Realizar testes microbiológicos para se verificar as culturas de microrganismos que estavam presentes no lodo e as que foram selecionadas após a adaptação e após a operação do sistema;

- Testar diferentes tempos de detenção no sistema;

- Verificar a máxima capacidade de eliminação que o sistema pode atingir;

- Testar o sistema para diferentes tipos de gases, como os compostos orgânicos voláteis e compostos reduzidos de nitrogênio;

- Estudar a ampliação de escala de um sistema de biofiltração, e fazer um estudo de custos para a aplicação do biofiltro em escala real. 


\section{REFERÊNCIAS BIBLIOGRÁFICAS}

APHA - AMERICAN PUBLIC HEALTH ASSOCIATION Standard Methods for the Examination of Water and Wastewater, Washington, Sixteenth Edition, 1986, 1268p.

ARAÚJO, J. C. Caracterização e evolução do biofilme em reator anaeróbio de leito fluidificado alimentado com esgoto sanitário sintético. 1995. Dissertação (Mestrado), Escola de Engenharia de São Carlos, Universidade de São Paulo, São Carlos.

BIBEAU, L., KIARED, K., LEROUX, A., BRZEZINSKI, R., VIEL, G., HEITZ, M. Biological purification of exhaust air containing toluene vapor in a filter-bed reactor. Canadian Journal of Chemical Engineering, 75 : 921-929, 1997.

BRAUER, H. Biological purification of waste gases. Int Chem Eng. Vol. 26, p. 387 - 395, 1986.

BUISMAN C., IJSPEERT, P., JANSEN A., LETTINGA, G. Kinetics of chemical and biological sulphide oxidation in aqueous solutions. Water Research, 24 (5): 667-671, 1990.

BURGESS, J. E.; PARSONS, S. A.; STUETZ, R. M. Developments in odour control and waste gas treatment biotechnology: a review., Biotechnology Advances, vol. 19, p. 35-63, 2001.

BUSCA, G.; PISTARINO, C. Technologies for the abatement of sulphide compounds from gaseous streams: a comparative overview. Journal of Loss Prevention in the Process Industries. 16, 363-371, 2003.

CABRAL, F.A.S.; Biofiltração para desodorização de reatores anaeróbios. Dissertação de Mestrado do Departamento de Engenharia Sanitária e Ambiental - Universidade Federal de Santa Catarina, 2003

CHA, J.M., CHA,W.S., LEE, J.H. Removal of organo-sulphur odour compounds by Thiobacillus novellus SRM, sulphur-oxidizing microorganisms. Process Biochemistry 34 (1999) 659-665. 
CHO, K.S., HIRAI, M., AND SHODA, M. Degradation characteristics of hydrogen sulfide, methanethiol, dimethyl sulfide and dimethyl disulfide by Thiobacillus thioparus DW44 isolated from peat biofilter. J. Ferment. Bioeng 71, 384-389. 1991.

CHO, K.S. ; HIRAI, M.; SHODA, M.; Enhanced removal efficiency of malodorous gases in a pilot-scale peat biofilter inoculated with Thiobacillus thioparus DW44. Journal of fermentation and bioengineering, vol.73, No. 1, 46-50, 1992a.

CHO, K.S. ; HIRAI, M.; SHODA, M.; Degradation of hydrogen sulfide by Xantomanas $s p$. strain DY44 isolated from peat. Applied and environmental microbiology, april, p. 1183-1189, $1992 b$.

CHOU, M.S., CHENG, W.H. Screening of biofiltering material for VOC treatment. Journal of the Air \& Waste Management Association, 47(6), 674-681, 1997.

CHUNG, Y.C.; HUANG, C.; TSENG, C.P. Operation optimization of Thiobacillus thioparus GCH11 biofilter for hydrogen sulfide removal. Journal of Biotechnology, 52: 31-38, 1996a.

CHUNG, Y.C.; HUANG, C.; TSENG, C.P. Biodegradation of hydrogen sulfide by a laboratory-scale immobilized Pseudomonas putida $\mathrm{CH} 11$ biofilter. Biotechnology Progress, 12(6): 773-778, 1996b.

CHUNG, Y.C., HUANG C. LI. C.F. Removal characteristics of H2S by Thiobacillus novellous $\mathrm{CH} 3$ biofilter in autotrophic and mixotrophic environments. Journal of Environmental Science and Health A32 (5): 1435-1450. 1997.

CHUNG, Y. C.; HUANG, C.; TSENG, C. P.; PAN, J. R. Biotreatment of $\mathrm{H}_{2} \mathrm{~S}$ and $\mathrm{NH}_{3}$ containing waste gases by co-immobilized cells biofilter., Chemosphere, vol. 41, p. 329-336, 2000.

CHUNG, Y.C., HUANG, C., TSENG,C.P. Biological elimination of $\mathrm{H}_{2} \mathrm{~S}$ and $\mathrm{NH}_{3}$ from waste gases by biofilter packed with immobilized heterotrophic bacteria. Chemosphere, 43: 1043-1050, 2001. 
CLARK, O.G., EDEOGU, I. FEDDES, J. COLEMAN R.N. ABOLGHASEMI. A. Effects of operating temperature and supplemental nutrients in a pilot-scale agricultural biofilter, Canadian Biosystems Engineering 46: 6.7-6.16. 2004.

CLEAN AIR ACT, 1970, United States federal law, disponível eletronicamente em $<$ http://www.epa.gov/oar/caa/contents.html> acesso dia 15 janeiro de 2007.

CONVERTI, A., ZILLI, M., SENE, L., SATO, S. Biofiltração: uma tecnologia já afirmada no tratamento de emissões gasosas. Farmácia \& Química São Paulo, vol 34(2), p. 2636, 2001.

CORSI, R.L., ET SEED, L. Biofiltration of BTEX: media, substrate, and loadings effects. Environmental Progress, 14(3): 151-158, 1995.

COX, H.H.J.; DESHUSSES, M.A., Biotrickling filters for air pollution control. In G. Bitton (Editor-in-Chief), The encyclopedia of Environmental Microbiology, 2000. Disponível em: <http://engr.ucr.edu/ mdeshuss/>. Acesso em 08 de jan., 2007.

DEGORCE-DUMAS, J. R. KOWAL, S. LE CLOIREC, P. Microbiological oxidation of hydrogen sulfide in biofilter. Canadian journal microbiology, V.43, p. 264-271, 1997.

DESHUSSES, M.A. Transient behavior of biofilters: start-up, carbon balances, and interactions between pollutants. Journal of Environmental Engineering, 123(6): 563$568,1997$.

DEVINNY, J. S.; DESHUSSES, M. A.; WEBSTER, T. S. Biofiltration for air pollution control. 1.ed. Florida, 1999. 299p.

DI BERNARDO, L.; MATHEUS, C. E. \& FRAGIACOMO, P. Ocorrência de bactérias fotossintetizantes em lagoas de estabilização - estudo de caso em indústria de charque. $15^{0}$ Congresso Brasileiro de Engenharia Sanitária e Ambiental, 366-377, 1989.

DOLFING, J.A., VAN DEN WIJNGAARD, J., JANSSEN, D.B. Microbiological aspects of the removal of chlorinated hydrocarbons from air. Biodegradation, 4, 261-282. 1993. 
EDWARDS, FG, NIRMALAKHANDAN, N. Biological Treatment of Airstreams Contamined with VOC's: na overview. Water Science Technology. 43 (3-4): 565-571. 1996.

ELIAS, A.; BARONA, A.; ARREGUY, A.; RIOS, J.; ARANGUIZ, I.; PEÑAS, J. Evaluation of a packing material for the biodegradation of $\mathrm{H}_{2} \mathrm{~S}$ and product analysis., Process Biochemistry, vol. 37, p. 813-820, 2002.

EPA - Environmental Protection Agency. Guide to field storage of biosolids. EPA/832-B00-007. July 2000.

ERGUN, S., Fluid flow through packed columns. Chemical Engineering Process. Vol. 48, 2, p. 89-94.

FOUST, A. S.; WENZEL, L. A.; CLUMP, C. W.; MAUS, L.; ANDERSEN, L. B. Principio das operações unitárias. 2 ed. Rio de Janeiro, Editora Guanabara Dois, 1982. $670 \mathrm{p}$.

FOX, R.W.; MACDONALD, A.T., Introdução a mecânica dos fluidos. 5 ed. Rio de Janeiro, Editora LTC, 1998. 504 p.

HARTIKAINEN, T.; RUUSKANEN, J.; MARTIKAINEN, P. J., Carbon disulfide and hydrogen sulfide removal with a peat biofilter. Journal of Air and Waste Management Association, v.51, p 387-392, 2001.

HARTIKAINEN, T., MARTIKAINEN, P. J., OLKONNEN, M., RUUSKANEN, J. Peat biofilters in long-term experiment for removing odorous sulphur compounds. Water, Air and Soil Pollution, 133, 335-348. 2002.

HEITZ, M., ROTHENBÜHLER, M., BEERLI, M., ET MARCOS, B. La biofiltration des émissions organiques volatiles dans l'industrie d'impression par le procédé de flexographie. Compte rendu du 6ième colloque sur les substances toxiques. Air and Waste Management Association, Montréal, Quebec., pp. 197-216. 1994.

HEITZ, M., VIEL, G., BRZEZINSKI, R., WU, G., KIARED, K., BIBEAU, L., CONTI, B. Procédé et appareil de traitement de l'air pollué par des solvants organiques volatils. Canada brevet n. 2, p. $211-564,1997$. 
HIRAI, M., OHTAKE, M., AND SHODA, M.. Removal kinetics of hydrogen sulfide, methanethiol and dimethyl sulfide by peat biofilters. J. Ferment. Bioeng. 70, 334339. 1990.

HIRAI, M., KAMAMOTO, M., YANI, M., SHODA., Comparison of the biological $\mathrm{H}_{2} \mathrm{~S}$ removal characteristics among four inorganics packing materials. Journal of Bioscience and Bioengineering, v.91, n4, p. 396-402, $2001 \mathrm{a}$.

HIRAI, M., KAMAMOTO, M., YANI, M., SHODA., Comparison of the biological $\mathrm{NH}_{3}$ removal characteristics among four inorganics packing materials. Journal of Bioscience and Bioengineering, v.91, n4, p. 428-430, $2001 \mathrm{~b}$.

HODGE, D.S.; DEVINNY, J.S. 1994. Biofilter treatment of ethanol vapors. Environmental progress, 13(3) : 167-173.

HODGE, D.S., DEVINNY, J.S. Modeling removal of air contaminants by biofiltration. Journal of Environmental Engineering, 121(1) : 21-32, 1995.

HORIKAWA, M. S.; Purificação de biogás - Remoção de $\mathrm{H}_{2} \mathrm{~S}$. Dissertação de Mestrado do Departamento de Engenharia Química - UEM, 2001.

JANSSEN, A.J.H; LETTINGA G.; KEIZER A. Removal of hydrogen sulphide from wastewater and waste gases by biological conversion to elemental sulphur Colloidal and interfacial aspects of biologically produced sulphur particles. Colloids Surfaces A: Physicochem. Eng. Aspects, vol. 151, p. 389-397, 1999.

JONES, H.R. Pollution control and chemical recovery in the pulp and paper industry. Noyes Data Corporation, 1973

JORIO, H., KIARED, K., BRZEZINSKI, R., LEROUX, A., VIEL, G., HEITZ, M. Purification of air polluted by high concentrations of toluene and xylene in a pilot scale biofilter. Journal of Chemical Technology and Biotechnology, 73 : 183-196. 1998.

JORIO, H.; HEITZ M. Traitement de l'air par biofiltration., Canadian Journal of Civil Engineering, vol. 26, p. 402-424, 1999.

JOYCE, J. $\mathrm{H}_{2} \mathrm{~S}$ biological oxidation. Water environ technol, vol 5, p. 40-43, 1995. 
KANAGAWA, T., MIKAMI, E. Removal of methanethiol, dimethyl disulphide and hydrogen sulphide from contamined air by Thiobacillus thioparus TK-m. Appl. Environ. Microbiol. 55:555-8, 1989

KENNES, C.; THALASSO, F. Waste gas biotreatment technology. J Chem Technol Biotechnol,; vol. 72, p. 303-319. 1998

KIM, H., KIM, J.Y.. CHUNG S.J XIE, Q. .Long-term operation of a biofilter for simultaneous removal of $\mathrm{H} 2 \mathrm{~S}$ and NH3. Air \& Waste Management Association 52: 1389-1398. 2002.

KLEEREBEZEM, R. MENDEZ. R. Autotrophic denitrification for combined hydrogen sulfide removal from biogas and post-denitrification. Water Science and Technology 45(10): 349-356. 2002.

KOWAL, S., FANLO, J. L., DEGORCE-DUMAS, J. R., AND LE CLOIREC, P. Deodorization with a biofilter using a consumable support: example of BSE process for hydrogen sulfide removal. Poll. Atm. 34-42. 1992.

LE CLOIREC, P.; HUMEAU, P.; RAMIREZ-LOPEZ, E.M., Biotreatments of odours: control and performance of a biofilter and a bioscrubber. Water Science ande Technology, vol 44, n 9, p 219-226, 1991.

LEE, E.Y.; CHO, K.S.; RYU, H.W., Simultaneous removal of $\mathrm{H}_{2} \mathrm{~S}$ and $\mathrm{NH}_{3}$ in biofilter inoculated with Acidithiobacillus thiooxidansTAS. Journal of Bioscience and Bioengineering, vol 99, n 6, p 611-615, 2005.

LI, X.W., HOFF, S.J., BUNDY, D.S., HARMON, J., XIN, H., ZHU, J. Biofilter: a malodor control technology for livestock industry. Journal of Environmental Science and Health. Part A, Environmental Science and Engineering, 31 (9): 2275-2285. 1996.

LI, X.Z.; WU, J.S.; SUN, D.L., Hydrogen sulphide and volatile fatty acid removal from foul air in a fibrous bed bioreactor. Water Science and Technology, vol 38, n 3, p 323-329, 1998. 
LIE, T.J., LEADBETTER, J.R., LEADBETTER, E.R. Metabolism of sulfonic acids and other organosulfur compounds by sulphate-reducing bacteria. J geomicrobiol, 15(2), p. 135-149, 1998.

LIPTÁK, B.G. Environmental air pollution control : air pollution. Ontário, Chilton Book Company, vol. 2, 1974, 1339p.

MAKA, A., CORK. D. Quantum efficiency requirements for an anaerobic photobioreator. Journal of Industrial Microbiology 5: 337-354. 1990.

MACINTYRE, A.J. Ventilação industrial e controle da poluição. 2.ed. Rio de Janeiro, Guanabara, 1990. 403p.

MAIA, G.D. Tratamento biológico de gás sulfídrico $\left(\mathrm{H}_{2} \mathrm{~S}\right)$ em biofiltro, Dissertação de Mestrado, Universidade Federal de São Carlos, Departamento de Engenharia Química, São Carlos, 2003, 176p.

MALHAUTIER, L., C. GRACIAN, C.J. ROUX, L.J. FANLO AND P. LE CLOIREC. Biological treatment process of air loaded with an ammonia and hydrogen sulfide mixture. Chemosphere 50: 145-153. 2003.

MANAHAN, S. E. Environmental chemistry. 6.ed. Boca Raton, Lewis Publishers, 1994 $811 \mathrm{p}$.

McCABE, W. L.; SMITH, J. C.; HARRIOT, P. Unit operations of chemical engineering.

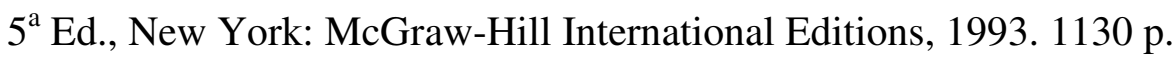

MOE, W. M., IRVINE, R. L. Polyurethane foam medium for biofiltration I: Characterization. Journal of Environmental Engineering. September, p. 815-825, 2000a.

MOE, W. M., IRVINE, R. L. Polyurethane foam medium for biofiltration II: Operation and performance. Journal of Environmental Engineering. September, p. 826-835, 2000b. 
MORAES JÚNIOR, D. Metodologia para o estudo de um sistema biológico de tratamento de emissões gasosas e aplicação na depuração do gás amoníaco. Tese de Doutoramento, EESC/USP - São Carlos, 1991, 197p.

MORGAN-SAGASTUME, M.J., A. NOYOLA, S. REVAH AND J.S. ERGAS. Changes in physical properties of a compost biofilter treating hydrogen sulfide. Journal of Air \& Waste Management Association 53: 1011-1021. 2003.

MORGAN-SAGASTUME, M.J.; NOYOLA, A., Hydrogen sulfide removal by compost biofiltration: Effect of mixing the filter media on operational factors. Bioresource Technology, 97, p 1546-1553, 2006.

NOYOLA, A.; MORGAN-SAGASTUME, M. J.; LÓPEZ-HERNÁNDEZ, J. E. Treatment of biogas produced in anaerobic reactors for domestic wastewater: odor control and energy/resource recovery. Environmental Science and Technology, 5, p 93-114, 2006.

OPRIME, M.E.A.G., Processo combinado químico-bacteriano para a remoção de $\mathrm{H}_{2} \mathrm{~S}$ de gases, Tese de Doutorado apresentada ao Instituto de Química do Campus de Araraquara da Universidade Estadual Paulista, 2001.

OTTENGRAFT, S. P .P.; VAN DER OEVER, A. H.C. Kinects of organic compounds removal from waste gases with biological filter. Biotechology and Bioengineering, v.25, p.3089-3102, 1983.

OYARZÚN, P.; ARANCIBIA, F.; CANALES, C.; AROCA, G. E. Biofiltration of high concentration of hydrogen sulphide using Thiobacillus thioparus., Process Biochemistry, vol. 39, p. 165-170, 2003.

OSTOJIC, N., LES, A. P., FORBES, R. Activated sludge treatment for odor control. Biocycle, 74-78, 1992.

PARK, D.H.; CHA, J.M.; RYU, H.W. LEE, .G.W.; YU, E.Y.; RHEE, J.I.; PARK, J.J; KIM, S.W.; LEE, I.W.; JOE, Y.I.; RYU, Y.W.; HUR, B.K.; PARK, J.K.; PARK, K., Hydrogen sulfide removal utilizing immobilized Thiobacillus sp. IW with Ca-alginate bead, Biochemical Engineering Journal, 11, p. 167-173, 2002. 
RANDS, M. B.; COOPER, D. E.; WOO, C. P.; FleTCHER, G. C.; ROLFE, K. A. Compost filters for $\mathrm{H}_{2} \mathrm{~S}$ removal from anaerobic digestion and rendering exhausts. Journal WPCF, v. 53, n. 2, p. 185-189, 1981.

RODRIGUES, K. B. Desenvolvimento de uma unidade experimental para degradação de gás sulfídrico $\left(\mathrm{H}_{2} \mathrm{~S}\right)$ em filtro biológico. Dissertação (Mestrado) - DEQ-UFSCar, 2002a.

RODRIGUES, C. C. Contribuição ao estudo do tratamento do gás amoníaco por adsorção em leito fixo de carvão ativado. Tese de Doutorado - DEQ-UFSCar, 2002b.

SYED, M., SOREANU, G., FALLETTA, P., BÉLAND, M. Removalof hydrogen sulfide from gas streams using biological processes - A review. Canadian Biosystems Engineering, vol. 48, 2.1-2.14, 2006.

SMET, E., CHASAYA, G., VAN LANGENHOVE, H., VERSTRAETE, W. The effect of inoculation and the type of carrier material used on the biofiltration of methyl sulfides. Applied Microbiology Biotechnology, 45(1-2): 293-298, 1996.

SMET, E. LENS, P. VAN LANGENHOVE H. Treatment of Waste Gases Contaminated with Odorous Sulfur Compounds. Critical Reviews in Environmental Science and Technology, 28(1), 89-117, 1998.

SMITH, F.L., SORIAL, G.A., SUIDAN, M.T., BREEN, A., BISWAS, P., BRENNER, R.C. Development of two biomass control strategies for extended, stable operation of highly efficient biofilters with hightoluene loadings. Environmental Science Technology, 30(5): 1744-1751. 1996.

SORIAL, G.A., SMITH, F.L., SUIDAN, M.T., BISWAS, P., ET BRENNER, R.C Performance of peat biofilter: impact of the empty bed residence time, temperature and toluene loading. Journal of Hazardous Materials, 53(1-3): 19-33. . 1997.

STERN, A.C. Air pollution 3.ed. Academic Press, New York,1976. v.3, p.866.

SUBLETTE, K.L., SYLVESTER, N.D. Oxidation of hydrogen sulfide by continuous cultures of Thiobacillus denitrificans., Biotechnology and Bioengineering 29, 753-758, 1987. 
SWANSON, W.J., LOEHR, R.C. Biofiltration: fundamentals, design and operations principles, and applications. Journal of Environmental Engineering, 123(6): 538-546. 1997.

TACLA, R. M. B.; Aproveitamento de resíduos industriais para a biofiltração de sulfeto de hidrogênio. Dissertação de mestrado do Departamento de Engenharia Química da universidade Federal do Paraná, 2004, 162 p.

VAN GROENESTIJN, J.W., HESSLINK, P.G.M. Biotechniques for air pollution control. Biodegradation, 4 : 283-301, 1993.

VAN LANGENHOVE, H.; WUYTS, E.; SCHAMP, N. Elimination of hydrogen sulphide from odorous air by a wood bark biofilter. Water Research, vol. 20, 12, p 1471-1476. 1986.

VAN LITH, C., LESON, G., ET MICHELSON, R. Evaluating design options for biofilters. Journal of the Air \& Waste Management Association, 47: 37-48. 1997.

VARESCHE, M.B.A.; Estudo com bactérias fototróficas anoxigênicas: enriquecimento, isolamento, caracterização nutricional e cinética de crescimento. Tese de Doutorado do Departamento de Hidráulica e Saneamento - EESC-USP, 1997, 2 V.

WADA, A. SHODA, M. KUBOTA, H. KOBAYASHI, T, KATAYAMA-FUJIMURA, Y. KURAISHI, $\mathrm{H}$. Characteristics of $\mathrm{H}_{2} \mathrm{~S}$ oxidizing bacteria inhabiliting a peat biofilter. Journal fermentation technology, v.64, n.2, p. 161-167, 1986.

WANG, Z., GOVIND, R., BISHOP, D.F. Effect of support media on biofiltration of volatile organic compounds (VOCs). Proceedings of the Industrial Waste Conference, Ann Arbor Press, Ann Arbor, Mich.Vol. 51. p. 201-211, 1997.

WANI, A.H., BRANION, R.M.R., LAU, A.K. Biofiltration: a promising and cost-effective control technology for odors, VOCs and air toxics. Journal of Environmental Science and Health. Part A, Environmental Science and Engineering, 32(7): 2027-2055. 1997. 
WANI, A.H., BRANION, R.M.R., LAU, A.K. Effects of periods of starvation and fluctuating hydrogen sulfide concentration on biofilter dynamics and performance, Journal of Hazardous Materials, vol 60, p. 287-303, 1998

WANI, A.H., LAU, A.K., BRANION, R.M.R. Biofiltration control of pulping odors hydrogen sulfide: performance, macrokinetics and coexistence effects of organo-sulfur species. Journal of Chemical Technology and Biotechnology, v.74, p.9-16. 1999.

WANNER, O., CUNNINGHAM, A.B., ET LUNDMAN, R. Modeling biofilm accumulation and mass transport in a porous medium under high substrate loading. Biotechnology and Bioengineering, 47 : 703-712, 1995.

WEBSTER, T.S., DEVINNY, J.S., TORRES, E.M., ET BASRAI, S.S. 1997. Microbial ecosystems in compost and granular activated carbon biofilters. Biotechnology and Bioengineering, 53(3) : 296-303.

WILLIAMSON, S.J., Fundamentals of air pollution. Philippines, Addison-Wesley Publishing Company, 1973. 472 p.

WU, G., CHABOT, J.C., CARON, J.J., ET HEITZ, M. Biological elimination of volatile organic compounds from waste gases in a biofilter. Water, Air and Soil Pollution, 101(1-4) : 69-78. 1998.

WU, G., CONTI, B., VIEL, G., LEROUX, A., BRZEZINSKI, R., HEITZ, M. A high performance biofilter for VOC emission control. Journal of the Air and Waste Management, 49(2) : 185-192. 1999.

YANG,Y. ALLEN, E. R. Biofiltration control of hydrogen sulfide -1 design and operational parameters. Journal air and waste management association, v.44, p.863868, 1994.

ZHANG, L., HIRAI, M., AND SHODA, M.. Removal characteristics of dimethyl sulfide, methanethiol and hydrogen sulfide by Hyphomicrobium sp. I55 isolated from peat biofilter. J. Ferment. Bioeng. 72, 392-396, 1991 
ZOTIN, F.Z., O efeito de parede em colunas de recheio. São Carlos, Dissertação de mestrado - DEQ-UFSCar, 1985. 165 p. 


\section{ANEXOS}

Tabela de dados de operação do sistema.

\begin{tabular}{|c|c|c|c|c|c|c|c|c|c|c|}
\hline \multirow{2}{*}{ Fase } & \multirow{2}{*}{ Data } & \multirow{2}{*}{$\begin{array}{l}\text { Operação } \\
\text { (dia) }\end{array}$} & \multirow{2}{*}{ pH } & \multicolumn{2}{|c|}{$\mathrm{C}_{\mathrm{eH} 2 \mathrm{~S}}$} & \multicolumn{2}{|c|}{$\mathrm{C}_{\mathrm{sH} 2 \mathrm{~S}}$} & \multirow{2}{*}{$\mathrm{E}(\%)$} & \multirow{2}{*}{ Ec $\left(g \cdot m^{-3} \cdot h^{-1}\right)$} & \multirow{2}{*}{$L_{S}\left(g \cdot m^{-3} \cdot h^{-1}\right)$} \\
\hline & & & & mg. $\mathrm{L}^{-1}$ & ppm & mg. $L^{-1}$ & ppm & & & \\
\hline I & 19/09/06 & 1 & 6,02 & 0,106 & 76 & 0,005 & 4 & $95,04 \%$ & 6,23 & 6,55 \\
\hline I & 20/09/06 & 2 & 6,26 & 0,113 & 81 & 0,007 & 5 & $94,04 \%$ & 6,60 & 7,02 \\
\hline I & $22 / 09 / 06$ & 4 & 6,83 & 0,165 & 118 & 0,006 & 4 & $96,36 \%$ & 9,85 & 10,22 \\
\hline I & $25 / 09 / 06$ & 7 & 7,29 & 0,227 & 163 & 0,008 & 6 & $96,37 \%$ & 13,57 & 14,08 \\
\hline I & $26 / 09 / 06$ & 8 & 3,17 & 0,060 & 43 & 0,005 & 3 & $92,50 \%$ & 3,44 & 3,72 \\
\hline I & 28/09/06 & 10 & 5,52 & 0,181 & 130 & 0,000 & 0 & $100,00 \%$ & 11,20 & 11,20 \\
\hline I & $29 / 09 / 06$ & 11 & 6,19 & 0,242 & 173 & 0,000 & 0 & $100,00 \%$ & 14,96 & 14,96 \\
\hline I & 02/10/06 & 14 & 7,92 & 0,632 & 453 & 0,000 & 0 & $100,00 \%$ & 39,13 & 39,13 \\
\hline I & 02/10/06 & 14 & 7,90 & 0,579 & 415 & 0,000 & 0 & $100,00 \%$ & 35,87 & 35,87 \\
\hline I & 03/10/06 & 15 & 8,67 & 0,188 & 135 & 0,000 & 0 & $100,00 \%$ & 11,66 & 11,66 \\
\hline I & 04/10/06 & 16 & 7,79 & 0,365 & 261 & 0,000 & 0 & $100,00 \%$ & 22,58 & 22,58 \\
\hline II & 10/10/06 & 22 & 8,60 & 0,027 & 19 & 0,000 & 0 & $100,00 \%$ & 1,67 & 1,67 \\
\hline II & 10/10/06 & 22 & 7,90 & 0,282 & 202 & 0,000 & 0 & $100,00 \%$ & 17,47 & 17,47 \\
\hline II & 10/10/06 & 22 & 8,20 & 0,365 & 262 & 0,000 & 0 & $100,00 \%$ & 22,63 & 22,63 \\
\hline II & 10/10/06 & 22 & 8,20 & 0,374 & 268 & 0,000 & 0 & $100,00 \%$ & 23,19 & 23,19 \\
\hline II & $11 / 10 / 06$ & 23 & 8,50 & 0,371 & 266 & 0,001 & 1 & $99,80 \%$ & 22,96 & 23,00 \\
\hline II & $11 / 10 / 06$ & 23 & 8,00 & 0,392 & 281 & 0,000 & 0 & $100,00 \%$ & 24,30 & 24,30 \\
\hline
\end{tabular}




\begin{tabular}{|c|c|c|c|c|c|c|c|c|c|c|}
\hline Fase & Data & $\begin{array}{c}\text { Operação } \\
\text { (dia) }\end{array}$ & pH & mg. $\mathrm{L}^{-1}$ & ppm & mg. ${ }^{-1}$ & ppm & $\mathrm{E}(\%)$ & $\operatorname{Ec}\left(g \cdot m^{-3} \cdot h^{-1}\right)$ & $L_{S}\left(g \cdot m^{-3} \cdot h^{-1}\right)$ \\
\hline II & $12 / 10 / 06$ & 24 & 6,23 & 0,439 & 315 & 0,001 & 1 & $99,83 \%$ & 27,14 & 27,18 \\
\hline II & $13 / 10 / 06$ & 25 & 2,65 & 0,410 & 294 & 0,000 & 0 & $100,00 \%$ & 25,37 & 25,37 \\
\hline II & 16/10/06 & 28 & 6,00 & 0,421 & 302 & 0,000 & 0 & $100,00 \%$ & 26,07 & 26,07 \\
\hline II & 17/10/06 & 29 & 7,35 & 0,441 & 316 & 0,000 & 0 & $100,00 \%$ & 27,32 & 27,32 \\
\hline II & 18/10/06 & 30 & 8,30 & 0,734 & 526 & 0,000 & 0 & $100,00 \%$ & 45,45 & 45,45 \\
\hline II & 18/10/06 & 30 & 7,43 & 0,347 & 249 & 0,000 & 0 & $100,00 \%$ & 21,52 & 21,52 \\
\hline II & 19/10/06 & 31 & 7,00 & 0,365 & 261 & 0,001 & 1 & $99,79 \%$ & 22,54 & 22,58 \\
\hline II & $20 / 10 / 06$ & 32 & 6,55 & 0,380 & 273 & 0,000 & 0 & $100,00 \%$ & 23,56 & 23,56 \\
\hline III & 23/10/06 & 35 & 7,23 & 0,641 & 459 & 0,000 & 0 & $100,00 \%$ & 39,68 & 39,68 \\
\hline III & 24/10/06 & 36 & 7,14 & 0,575 & 412 & 0,000 & 0 & $100,00 \%$ & 35,60 & 35,60 \\
\hline III & 24/10/06 & 36 & 8,45 & 0,717 & 514 & 0,000 & 0 & $100,00 \%$ & 44,42 & 44,42 \\
\hline III & 25/10/06 & 37 & 8,16 & 0,739 & 530 & 0,000 & 0 & $100,00 \%$ & 45,77 & 45,77 \\
\hline III & 26/10/06 & 38 & 6,32 & 0,767 & 550 & 0,000 & 0 & $100,00 \%$ & 47,54 & 47,54 \\
\hline III & 27/10/06 & 39 & 8,60 & 0,829 & 594 & 0,000 & 0 & $100,00 \%$ & 51,35 & 51,35 \\
\hline III & $30 / 10 / 06$ & 42 & 6,00 & 0,751 & 538 & 0,000 & 0 & $100,00 \%$ & 46,52 & 46,52 \\
\hline IV & 01/11/06 & 44 & 7,19 & 0,853 & 612 & 0,323 & 232 & $62,09 \%$ & 32,81 & 52,84 \\
\hline IV & 03/11/06 & 46 & 7,17 & 0,878 & 629 & 0,000 & 0 & $100,00 \%$ & 54,37 & 54,37 \\
\hline IV & 06/11/06 & 49 & 6,62 & 0,879 & 630 & 0,789 & 566 & $10,24 \%$ & 5,58 & 54,46 \\
\hline IV & 06/11/06 & 49 & 6,62 & 0,905 & 649 & 0,800 & 574 & $11,53 \%$ & 6,46 & 56,04 \\
\hline IV & 07/11/06 & 50 & 6,54 & 0,908 & 651 & 0,620 & 444 & $31,74 \%$ & 17,84 & 56,23 \\
\hline IV & 07/11/06 & 50 & 6,53 & 0,640 & 459 & 0,179 & 128 & $72,10 \%$ & 28,58 & 39,64 \\
\hline IV & 08/11/06 & 51 & 7,35 & 0,050 & 36 & 0,002 & 1 & $97,01 \%$ & 3,02 & 3,11 \\
\hline IV & 08/11/06 & 51 & 7,05 & 0,632 & 453 & 0,006 & 4 & $99,05 \%$ & 38,76 & 39,13 \\
\hline IV & 08/11/06 & 51 & 7,12 & 0,924 & 663 & 0,278 & 199 & $69,97 \%$ & 40,06 & 57,25 \\
\hline IV & 08/11/06 & 51 & 7,10 & 0,748 & 536 & 0,146 & 105 & $80,44 \%$ & 37,27 & 46,33 \\
\hline IV & 09/11/06 & 52 & 7,24 & 0,965 & 692 & 0,177 & 127 & $81,66 \%$ & 48,84 & 59,81 \\
\hline IV & 09/11/06 & 52 & 7,24 & 0,818 & 586 & 0,122 & 88 & $85,05 \%$ & 43,08 & 50,65 \\
\hline IV & 09/11/06 & 52 & 7,20 & 0,777 & 557 & 0,074 & 53 & $90,44 \%$ & 43,54 & 48,14 \\
\hline IV & 09/11/06 & 52 & 7,20 & 0,782 & 560 & 0,080 & 58 & $89,73 \%$ & 43,45 & 48,42 \\
\hline
\end{tabular}




\begin{tabular}{|c|c|c|c|c|c|c|c|c|c|c|}
\hline Fase & Data & $\begin{array}{c}\text { Operação } \\
\text { (dia) }\end{array}$ & pH & \multicolumn{2}{|c|}{$\mathrm{C}_{\mathrm{eH} 2 \mathrm{~S}}$} & \multicolumn{2}{|c|}{$\mathrm{C}_{\mathrm{SH}_{2} \mathrm{~S}}$} & $\mathbf{E}(\%)$ & $\operatorname{Ec}\left(g \cdot m^{-3} \cdot h^{-1}\right)$ & $L_{S}\left(g \cdot m^{-3} \cdot h^{-1}\right)$ \\
\hline IV & $10 / 11 / 06$ & 53 & 7,32 & 0,533 & 382 & 0,026 & 18 & $95,21 \%$ & 31,41 & 32,99 \\
\hline IV & 10/11/06 & 53 & 7,32 & 0,700 & 502 & 0,024 & 17 & $96,57 \%$ & 41,87 & 43,36 \\
\hline IV & 11/11/06 & 54 & 7,56 & 0,704 & 505 & 0,026 & 18 & $96,38 \%$ & 42,05 & 43,63 \\
\hline IV & 12/11/06 & 55 & 7,80 & 0,701 & 503 & 0,021 & 15 & $97,01 \%$ & 42,15 & 43,45 \\
\hline IV & 13/11/06 & 56 & 6,95 & 0,689 & 494 & 0,032 & 23 & $95,42 \%$ & 40,71 & 42,66 \\
\hline V & 14/11/06 & 57 & 7,52 & 0,933 & 669 & 0,000 & 0 & $100,00 \%$ & 57,81 & 57,81 \\
\hline V & 14/11/06 & 57 & 7,49 & 0,718 & 515 & 0,000 & 0 & $100,00 \%$ & 44,47 & 44,47 \\
\hline V & $15 / 11 / 06$ & 58 & 7,42 & 0,710 & 509 & 0,000 & 0 & $100,00 \%$ & 43,96 & 43,96 \\
\hline V & 16/11/06 & 59 & 8,00 & 0,702 & 503 & 0,000 & 0 & $100,00 \%$ & 43,50 & 43,50 \\
\hline $\mathrm{V}$ & 17/11/06 & 60 & 7,66 & 0,812 & 582 & 0,000 & 0 & $100,00 \%$ & 50,28 & 50,28 \\
\hline V & $20 / 11 / 06$ & 63 & 7,40 & 0,908 & 651 & 0,000 & 0 & $100,00 \%$ & 56,27 & 56,27 \\
\hline V & 21/11/06 & 64 & 7,71 & 0,868 & 622 & 0,000 & 0 & $100,00 \%$ & 53,76 & 53,76 \\
\hline $\mathrm{V}$ & $22 / 11 / 06$ & 65 & 8,32 & 0,816 & 585 & 0,000 & 0 & $100,00 \%$ & 50,56 & 50,56 \\
\hline V & 23/11/06 & 66 & 7,17 & 0,801 & 574 & 0,000 & 0 & $100,00 \%$ & 49,63 & 49,63 \\
\hline V & 24/11/06 & 67 & 8,41 & 0,738 & 529 & 0,000 & 0 & $100,00 \%$ & 45,73 & 45,73 \\
\hline V & 26/11/06 & 69 & 6,61 & 0,791 & 567 & 0,000 & 0 & $100,00 \%$ & 49,02 & 49,02 \\
\hline V & 27/11/06 & 70 & 7,00 & 0,747 & 536 & 0,000 & 0 & $100,00 \%$ & 46,28 & 46,28 \\
\hline V & 28/11/06 & 71 & 8,90 & 0,669 & 480 & 0,000 & 0 & $100,00 \%$ & 41,45 & 41,45 \\
\hline V & 29/11/06 & 72 & 7,90 & 0,920 & 660 & 0,000 & 0 & $100,00 \%$ & 57,02 & 57,02 \\
\hline V & $30 / 11 / 06$ & 73 & 7,50 & 1,031 & 739 & 0,000 & 0 & $100,00 \%$ & 63,85 & 63,85 \\
\hline VI & 01/12/06 & 74 & 7,56 & 1,277 & 916 & 0,340 & 244 & $73,39 \%$ & 58,06 & 79,11 \\
\hline VI & 01/12/06 & 74 & 7,56 & 0,903 & 648 & 0,475 & 340 & $47,45 \%$ & 26,56 & 55,97 \\
\hline VI & 02/12/06 & 75 & 7,80 & 1,068 & 766 & 0,285 & 204 & $73,34 \%$ & 48,51 & 66,15 \\
\hline VI & 03/12/06 & 76 & 7,73 & 1,123 & 805 & 0,225 & 161 & $79,96 \%$ & 55,62 & 69,56 \\
\hline VI & 04/12/06 & 77 & 7,66 & 1,445 & 1036 & 0,407 & 292 & $71,81 \%$ & 64,27 & 89,50 \\
\hline VI & 04/12/06 & 77 & 7,00 & 1,155 & 829 & 0,187 & 134 & $83,84 \%$ & 60,01 & 71,59 \\
\hline VI & 05/12/06 & 78 & 7,50 & 1,182 & 848 & 0,006 & 4 & $99,52 \%$ & 72,91 & 73,26 \\
\hline VI & 06/12/06 & 79 & 7,00 & 1,190 & 854 & 0,014 & 10 & $98,87 \%$ & 72,91 & 73,75 \\
\hline VI & 07/12/06 & 80 & 6,89 & 1,254 & 900 & 0,018 & 13 & $98,57 \%$ & 76,60 & 77,72 \\
\hline
\end{tabular}




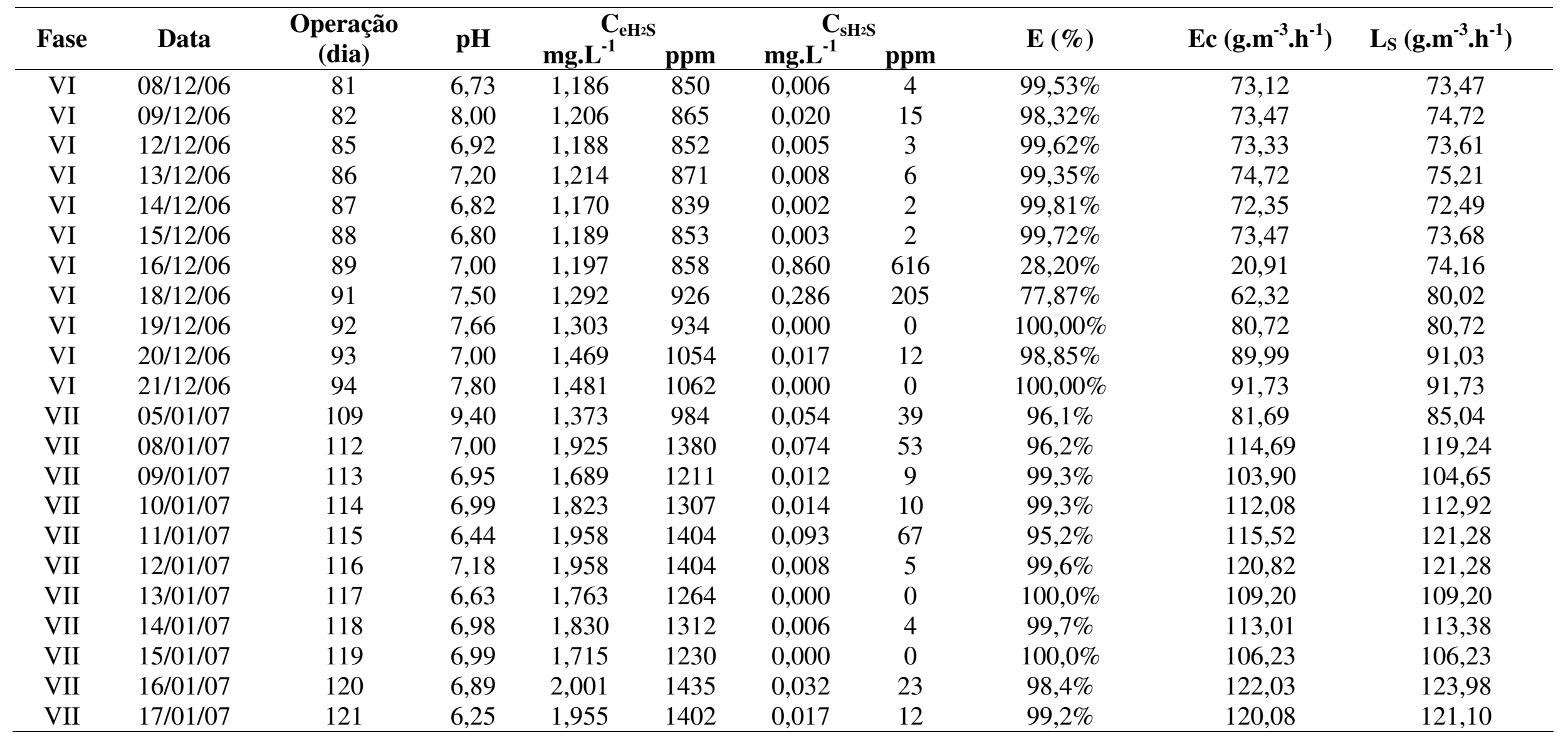


Dados da curva de adsorção

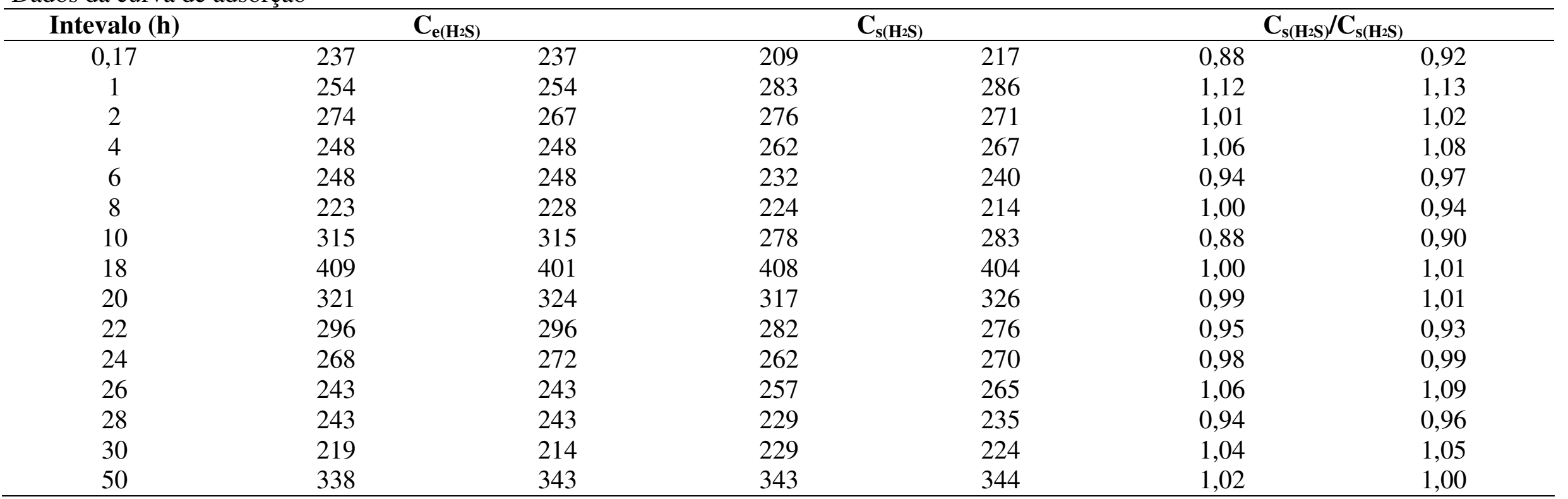

Dados do perfil de degradação

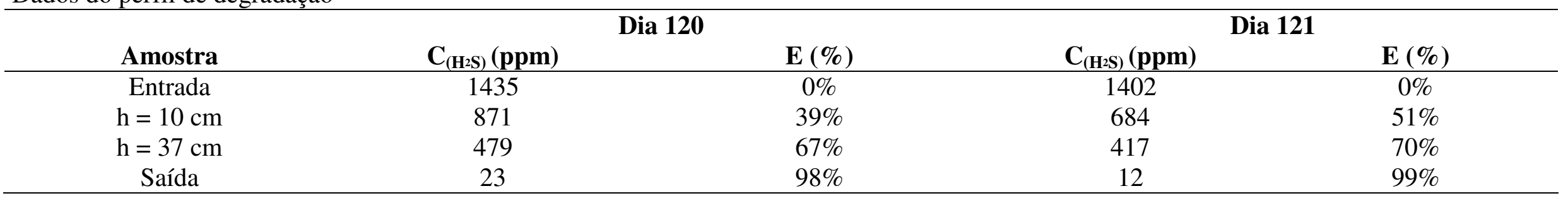


Dados hidrodinâmicos da coluna seca

\begin{tabular}{|c|c|c|c|c|c|c|c|c|c|c|c|c|c|c|}
\hline & & & Seca 1 & & & Seca 2 & & & Seca 3 & & & Média & & ERGUN \\
\hline$\underset{\mathrm{cm} \cdot \mathrm{s}^{-1}}{\mathrm{~V}}$ & $\underset{\mathrm{cm}^{3} \cdot \mathrm{s}^{-1}}{\mathrm{Q}}$ & $\begin{array}{c}\Delta \mathrm{P} \\
10^{-2} \mathrm{mca}\end{array}$ & $\begin{array}{c}\Delta \mathrm{P} \\
\text { dina.cm }\end{array}$ & $\underset{\text { g.cm }}{\Delta \mathrm{P} / \mathrm{L}}$ & $\begin{array}{c}\Delta \mathrm{P} \\
10^{-2} \mathrm{mca}\end{array}$ & $\begin{array}{c}\Delta \mathrm{P} \\
\text { dina.cm }^{-2}\end{array}$ & $\begin{array}{c}\Delta \mathrm{P} / \mathrm{L} \\
\mathrm{g} \cdot \mathrm{cm}^{-2} \cdot \mathrm{s}^{-2}\end{array}$ & $\begin{array}{c}\Delta \mathrm{P} \\
10^{-2} \mathrm{mca}\end{array}$ & $\underset{\text { dina.cm }}{\Delta \mathrm{P}}$ & $\underset{\text { g.cm }}{\Delta \mathrm{P} / \mathrm{L}}$ & $\begin{array}{c}\Delta \mathrm{P} \\
10^{-2} \mathrm{mca}\end{array}$ & $\begin{array}{c}\Delta \mathrm{P} \\
\text { dina.cm }^{-2}\end{array}$ & $\underset{\text { g.cm }}{\Delta \mathrm{P} / \mathrm{L}}$ & $\underset{\text { g.cm }}{\Delta \mathrm{P} / \mathrm{L}}$ \\
\hline 0,40 & 8 & 0,10 & 100 & 1,31 & 0,29 & 280 & 3,68 & 0,16 & 160 & 2,10 & 0,18 & 180 & 2,37 & 1,25 \\
\hline 0,85 & 18 & 0,18 & 180 & 2,37 & 0,37 & 360 & 4,73 & 0,24 & 240 & 3,15 & 0,27 & 260 & 3,42 & 2,71 \\
\hline 1,05 & 22 & 0,20 & 200 & 2,63 & 0,41 & 400 & 5,26 & 0,27 & 260 & 3,42 & 0,29 & 286 & 3,77 & 3,39 \\
\hline 1,22 & 26 & 0,24 & 240 & 3,15 & 0,51 & 499 & 6,57 & 0,29 & 280 & 3,68 & 0,35 & 340 & 4,47 & 3,97 \\
\hline 1,37 & 29 & 0,29 & 280 & 3,68 & 0,53 & 519 & 6,83 & 0,31 & 300 & 3,94 & 0,37 & 366 & 4,82 & 4,49 \\
\hline 1,75 & 37 & 0,37 & 360 & 4,73 & 0,67 & 659 & 8,67 & 0,39 & 380 & 4,99 & 0,48 & 466 & 6,13 & 5,83 \\
\hline 1,86 & 39 & 0,39 & 380 & 4,99 & 0,69 & 679 & 8,94 & 0,41 & 400 & 5,26 & 0,50 & 486 & 6,40 & 6,22 \\
\hline 1,96 & 42 & 0,45 & 439 & 5,78 & 0,86 & 839 & 11,04 & 0,51 & 499 & 6,57 & 0,61 & 593 & 7,80 & 6,60 \\
\hline
\end{tabular}

Dados hidrodinâmicos da coluna úmida

\begin{tabular}{|c|c|c|c|c|c|c|c|c|c|c|c|c|c|}
\hline \multirow[b]{2}{*}{$\begin{array}{c}\mathrm{V} \\
\mathrm{cm} \cdot \mathrm{s}^{-1}\end{array}$} & \multirow[b]{2}{*}{$\begin{array}{c}\mathrm{Q} \\
\mathrm{cm}^{3} \cdot \mathrm{s}^{-1}\end{array}$} & \multicolumn{3}{|c|}{ Úmida 1} & \multicolumn{3}{|c|}{ Úmida 2} & \multicolumn{3}{|c|}{ Úmida 3} & \multicolumn{3}{|c|}{ Média } \\
\hline & & $\underset{10^{-2} \mathrm{mca}}{\Delta \mathrm{P}}$ & $\begin{array}{c}\Delta \mathrm{P} \\
\text { dina.cm } \\
\text { din }\end{array}$ & $\begin{array}{c}\Delta \mathrm{P} / \mathrm{L} \\
\mathrm{g} \cdot \mathrm{cm}^{-2} \cdot \mathrm{s}^{-2}\end{array}$ & $\underset{10^{-2} \mathrm{mca}}{\Delta \mathrm{P}}$ & $\begin{array}{c}\Delta \mathrm{P} \\
\text { dina.cm }^{-2}\end{array}$ & $\begin{array}{c}\Delta \mathrm{P} / \mathrm{L} \\
\text { g.cm }{ }^{-2} \cdot \mathrm{s}^{-2}\end{array}$ & $\begin{array}{c}\Delta \mathrm{P} \\
10^{-2} \mathrm{mca}\end{array}$ & $\begin{array}{c}\Delta \mathrm{P} \\
\text { dina.cm } \\
\text { din }\end{array}$ & $\begin{array}{c}\Delta \mathrm{P} / \mathrm{L} \\
\text { g.cm }{ }^{-2} \cdot \mathrm{s}^{-2}\end{array}$ & $\underset{10^{-2} \mathrm{mca}}{\Delta \mathrm{P}}$ & $\begin{array}{c}\Delta \mathrm{P} \\
\text { dina.cm } \\
\text { din }\end{array}$ & $\begin{array}{c}\Delta \mathrm{P} / \mathrm{L} \\
\text { g.cm }{ }^{-2} \cdot \mathrm{s}^{-2}\end{array}$ \\
\hline 0,40 & 8 & 0,22 & 220 & 2,89 & 0,27 & 260 & 3,42 & 0,16 & 160 & 2,10 & 0,22 & 213 & 2,80 \\
\hline 0,59 & 12 & 0,29 & 280 & 3,68 & 0,33 & 320 & 4,21 & 0,24 & 240 & 3,15 & 0,29 & 280 & 3,68 \\
\hline 0,85 & 18 & 0,39 & 380 & 4,99 & 0,45 & 439 & 5,78 & 0,31 & 300 & 3,94 & 0,38 & 373 & 4,91 \\
\hline 1,05 & 22 & 0,51 & 499 & 6,57 & 0,55 & 539 & 7,10 & 0,35 & 340 & 4,47 & 0,47 & 459 & 6,05 \\
\hline 1,22 & 26 & 0,55 & 539 & 7,10 & 0,63 & 619 & 8,15 & 0,39 & 380 & 4,99 & 0,52 & 513 & 6,75 \\
\hline 1,37 & 29 & 0,59 & 579 & 7,62 & 0,67 & 659 & 8,67 & 0,45 & 439 & 5,78 & 0,57 & 559 & 7,36 \\
\hline 1,51 & 32 & 0,65 & 639 & 8,41 & 0,78 & 759 & 9,99 & 0,51 & 499 & 6,57 & 0,65 & 633 & 8,32 \\
\hline 1,63 & 35 & 0,71 & 699 & 9,20 & 0,80 & 779 & 10,25 & 0,61 & 599 & 7,89 & 0,71 & 693 & 9,11 \\
\hline 1,75 & 37 & 0,78 & 759 & 9,99 & 0,84 & 819 & 10,78 & 0,65 & 639 & 8,41 & 0,75 & 739 & 9,73 \\
\hline 1,86 & 39 & 0,84 & 819 & 10,78 & 0,90 & 879 & 11,57 & 0,69 & 679 & 8,94 & 0,81 & 792 & 10,43 \\
\hline 1,96 & 42 & 0,86 & 839 & 11,04 & 0,96 & 939 & 12,35 & 0,75 & 739 & 9,73 & 0,86 & 839 & 11,04 \\
\hline
\end{tabular}


Dados hidrodinâmicos da coluna após 121 dias de operação

\begin{tabular}{|c|c|c|c|c|c|c|c|c|c|c|c|c|c|c|}
\hline \multirow[b]{2}{*}{$\begin{array}{c}\mathrm{V} \\
\mathrm{cm} \cdot \mathrm{s}^{-1}\end{array}$} & \multirow[b]{2}{*}{$\begin{array}{c}\mathrm{Q} \\
\mathrm{cm}^{3} \cdot \mathrm{s}^{-1} \\
\end{array}$} & \multicolumn{3}{|c|}{ Operação $1(\mathrm{~L}=60 \mathrm{~cm})$} & \multicolumn{3}{|c|}{ Operação $2(\mathrm{~L}=60 \mathrm{~cm})$} & \multicolumn{3}{|c|}{ Operação $3(\mathrm{~L}=60 \mathrm{~cm})$} & \multicolumn{3}{|c|}{ Média $(\mathrm{L}=60 \mathrm{~cm})$} & \multirow{2}{*}{$\begin{array}{c}\mathrm{L} 76 \mathrm{~cm} \\
\Delta \mathrm{P} / \mathrm{L} \\
\mathrm{g} \cdot \mathrm{cm}^{-2} \cdot \mathrm{s}^{-2}\end{array}$} \\
\hline & & $\underset{10^{-2} \mathrm{mca}}{\Delta \mathrm{P}}$ & $\begin{array}{c}\Delta \mathrm{P} \\
\text { dina.cm } \\
\end{array}$ & $\begin{array}{c}\Delta \mathrm{P} / \mathrm{L} \\
\mathrm{g} \cdot \mathrm{cm}^{-2} \cdot \mathrm{s}^{-2}\end{array}$ & $\begin{array}{c}\Delta \mathrm{P} \\
10^{-2} \mathrm{mca}\end{array}$ & $\begin{array}{c}\Delta \mathrm{P} \\
\text { dina.cm } \\
\text { din }\end{array}$ & $\begin{array}{c}\Delta \mathrm{P} / \mathrm{L} \\
\text { g.cm } \mathrm{cm}^{-2} \cdot \mathrm{s}^{-2}\end{array}$ & $\begin{array}{c}\Delta \mathrm{P} \\
10^{-2} \mathrm{mca}\end{array}$ & $\begin{array}{c}\Delta \mathrm{P} \\
\text { dina.cm } \\
\text { ding }\end{array}$ & $\begin{array}{c}\Delta \mathrm{P} / \mathrm{L} \\
\mathrm{g} \cdot \mathrm{cm}^{-2} \cdot \mathrm{s}^{-2}\end{array}$ & $\underset{10^{-2} \mathrm{mca}}{\Delta \mathrm{P}}$ & $\begin{array}{c}\Delta \mathrm{P} \\
\text { dina.cm } \\
\end{array}$ & $\begin{array}{c}\Delta \mathrm{P} / \mathrm{L} \\
\text { g.cm }{ }^{-2} \cdot \mathrm{s}^{-2}\end{array}$ & \\
\hline 0,40 & 8 & 0,10 & 100 & 1,66 & 0,18 & 180 & 3,00 & 0,27 & 260 & 4,33 & 0,18 & 180 & 3,00 & 2,37 \\
\hline 0,59 & 12 & 0,20 & 200 & 3,33 & 0,31 & 300 & 4,99 & 0,41 & 400 & 6,66 & 0,31 & 300 & 4,99 & 3,94 \\
\hline 0,85 & 18 & 0,37 & 360 & 5,99 & 0,47 & 459 & 7,66 & 0,57 & 559 & 9,32 & 0,47 & 459 & 7,66 & 6,05 \\
\hline 1,05 & 22 & 0,45 & 439 & 7,32 & 0,61 & 599 & 9,99 & 0,71 & 699 & 11,65 & 0,59 & 579 & 9,66 & 7,62 \\
\hline 1,22 & 26 & 0,61 & 599 & 9,99 & 0,75 & 739 & 12,32 & 0,82 & 799 & 13,32 & 0,73 & 712 & 11,87 & 9,37 \\
\hline 1,37 & 29 & 0,67 & 659 & 10,99 & 0,82 & 799 & 13,32 & 0,90 & 879 & 14,65 & 0,80 & 779 & 12,98 & 10,25 \\
\hline 1,51 & 32 & 0,80 & 779 & 12,98 & 0,90 & 879 & 14,65 & 1,00 & 979 & 16,31 & 0,90 & 879 & 14,65 & 11,57 \\
\hline 1,63 & 35 & 0,90 & 879 & 14,65 & 1,00 & 979 & 16,31 & 1,06 & 1039 & 17,31 & 0,99 & 966 & 16,09 & 12,70 \\
\hline 1,75 & 37 & 1,00 & 979 & 16,31 & 1,10 & 1079 & 17,98 & 1,12 & 1099 & 18,31 & 1,07 & 1052 & 17,53 & 13,84 \\
\hline 1,86 & 39 & 1,08 & 1059 & 17,65 & 1,14 & 1119 & 18,64 & 1,18 & 1159 & 19,31 & 1,14 & 1112 & 18,53 & 14,63 \\
\hline 1,96 & 42 & 1,18 & 1159 & 19,31 & 1,18 & 1159 & 19,31 & 1,26 & 1239 & 20,64 & 1,21 & 1185 & 19,75 & 15,60 \\
\hline
\end{tabular}

